\title{
Adolescence and State Policy in Egypt [Arabic]
}

Halla E. Shafey

Follow this and additional works at: https://knowledgecommons.popcouncil.org/departments_sbsr-pgy How does access to this work benefit you? Let us know!

\section{Recommended Citation}

Shafey, Halla E. 1998. "Adolescence and State Policy in Egypt [in Arabic]." Cairo: Population Council. 

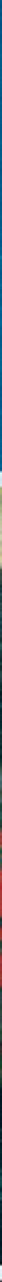

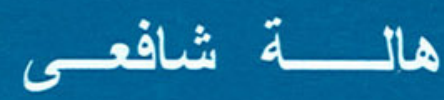

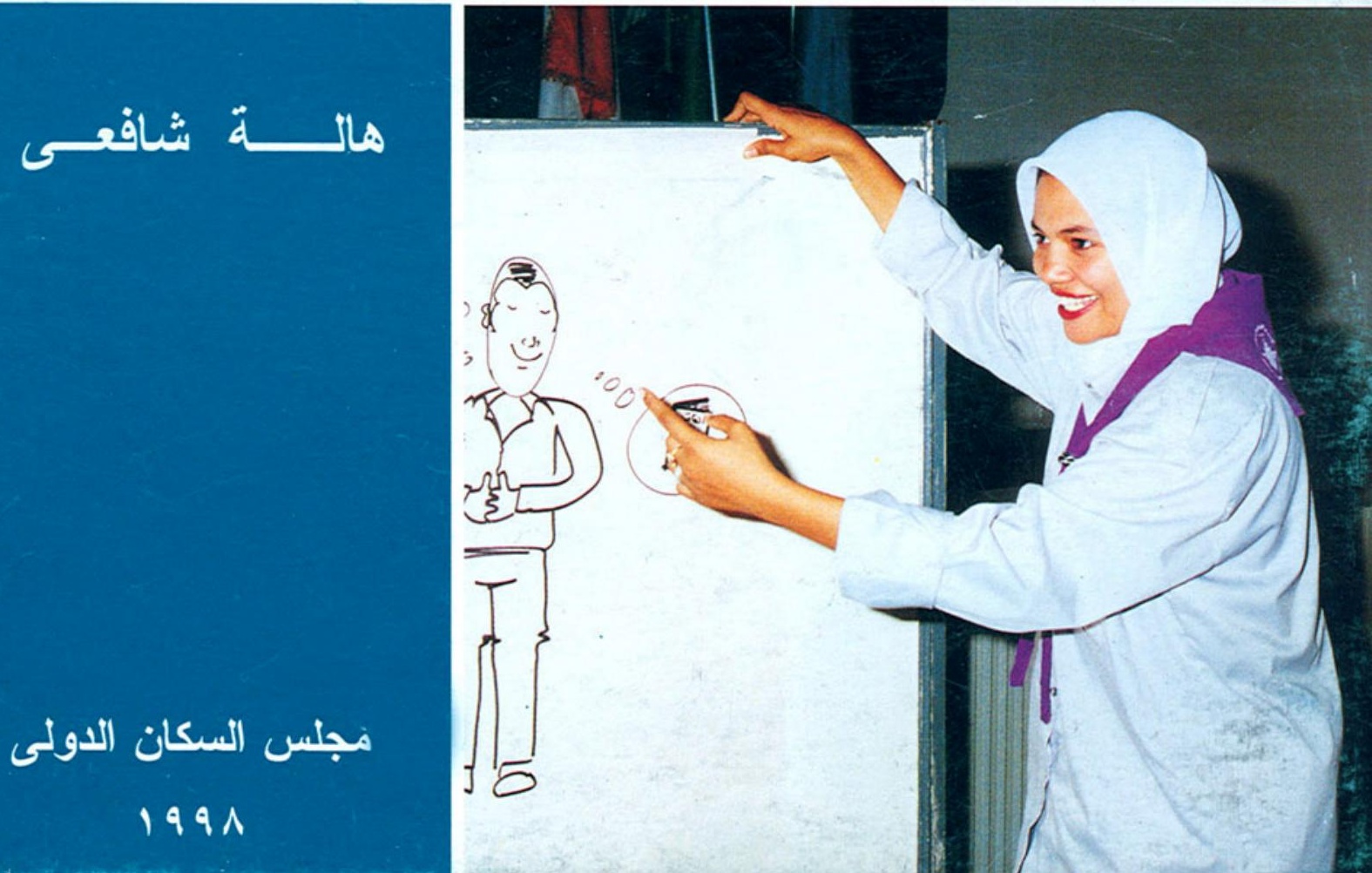




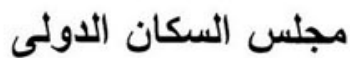 \\ Population Council \\ One Dag Hammarskjold Plaza \\ New York, NY 10017}

يسعى مجلس السكان إلى تحسين رفاهية الأجيال الحالية

و القادمة وصحتها الإنجايية فى كل أنحاء العالم.

كما يسعى إلى تحقيق توازن إنسانى منصف ومستدام بين السكان والموارد.

وللمجلس وهو منظمة بحثية غير حكومية ولا تسعى إلى تحقيق الربح،

مجلس أمناء متعدد الجنسيات. وقد أنشئ عام 190 1 ومقره الرئيسى فى

نيويورك وله شبكة عالمبة من المكاتب الإقليمية والقطرية

حقوق الطبع 1991 مجلس السكان الدولى

لمزيد من المعلومات و النسخ

رجاء الاتصال بمجلس السكان الدولى

منطقة غرب آسيا وشمال أفريقيا

ص . ب 10 / / الدقى / الجيزة / جمهورية مصر العربية

تليفون: roro970 (r.

فاكس:r) (ro097r)

pcouncil@pccairo.org : بريد إلكترونى 
النشء وسياسة الدولة فى مصر

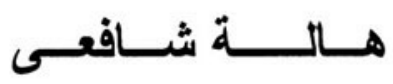

مجلس السكان الدولى 
ترجمة: عمر الشافعى 


\section{فهـرس}

تصدير

خلاصة لمنة

1

7

IV

rV

$\varepsilon Y$

09

vo

91

1.0

$11 \cdot / 1 \cdot 1$

$11 \varepsilon$

$11 \mathrm{~V}$
الغرض و النطاق و المنهج الإطار المفاهيمى

المر اهقة فى السياق المصرى: بعض الاستتتاجات العامة

الزواج و الصحة الإنجابية

عمل المر اهقين وتوظيفهم وقت الفر اغ واستتباعاته

النتائج و الثوصيات

الملحق(1): دليل المقابلات

الملحق(ץ): فيائمة المستشارين

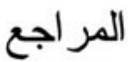

مقدمة:

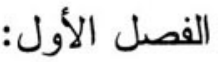

الفصل الثانى:

الفصل الثالث:

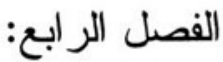

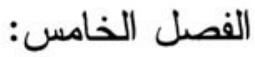

الفصل السادس: 
يمتل هذا العرض نهاية رحلة اكتشاف طويلة لأولئك الذين أســهموا في إنتاجه. فالمر اهقة أو النشء كموضو ع لم تخرج سوى مؤخر ا من دائسرة

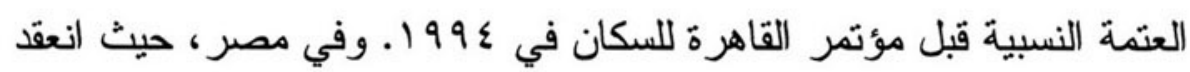

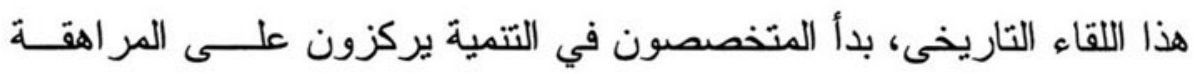

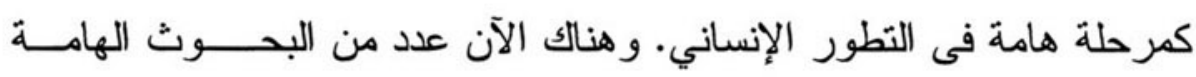

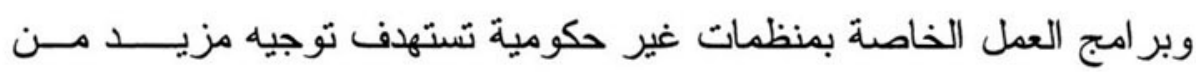

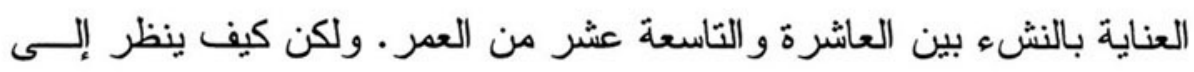

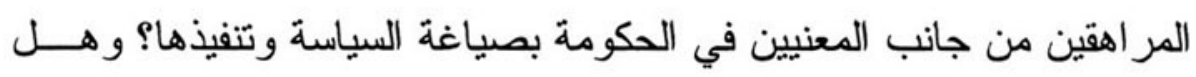

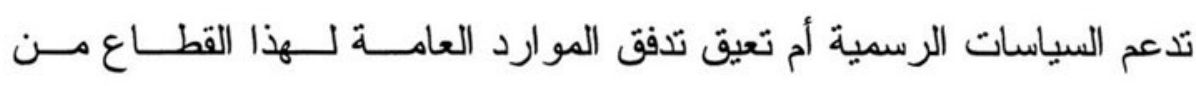

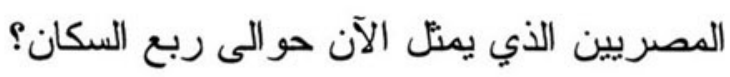

تلك كانت الأسئلة التى دفعت فريق البحث الخاص بالنشء فى مجلس

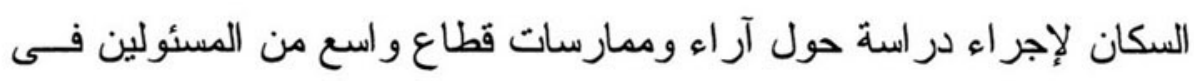
الحكومة المصرية. وسر عان ما تبين لنا أن الحكومات ليست كيانات مصمتة.

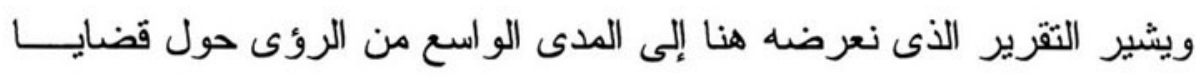

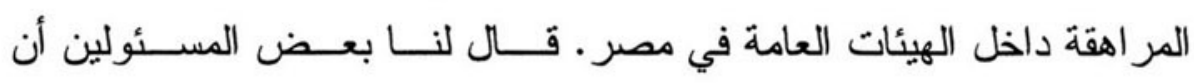

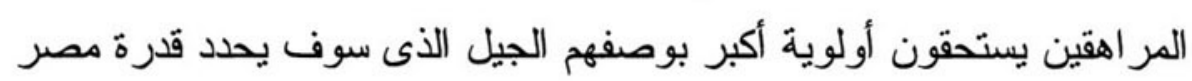

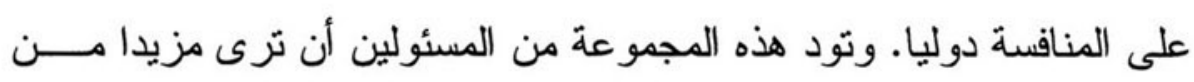

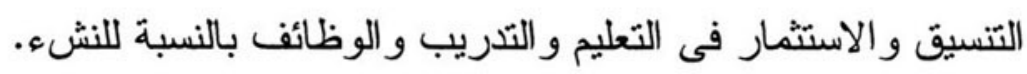

عبرت مجموعة أخرى عن القلق على المر اهقين بوصفهم قطاع مـن

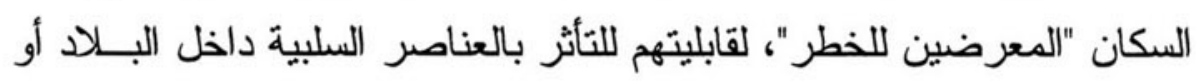

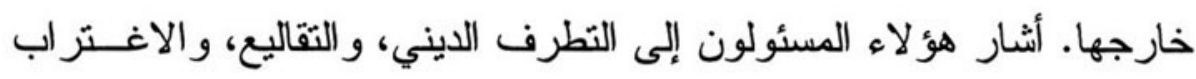


العام كأعر اض للمشكلة. و اقترحو ا تدعيم البر امج الثقافـــة وخلـق ســـاحات

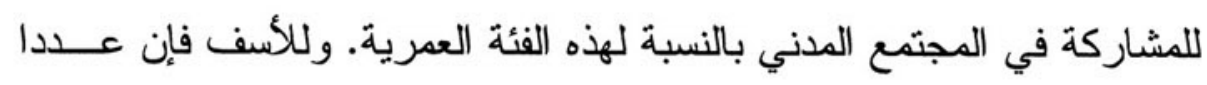

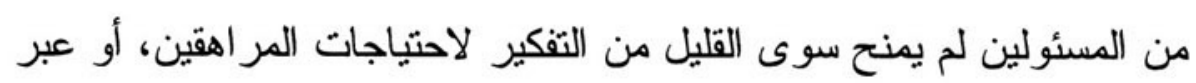
عن تفضيله السيطرة عليهم عوضا عن دعمهم.

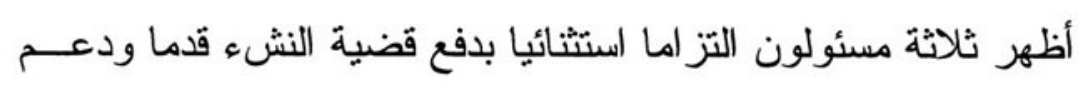

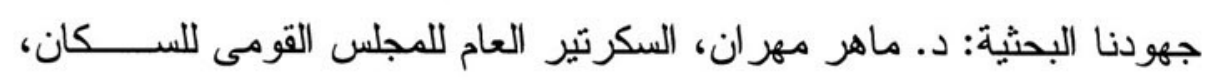

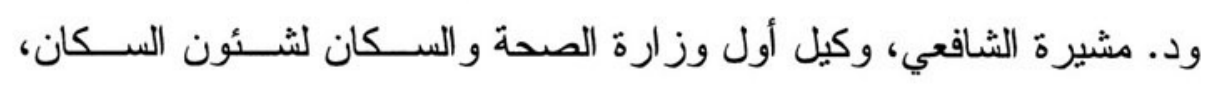

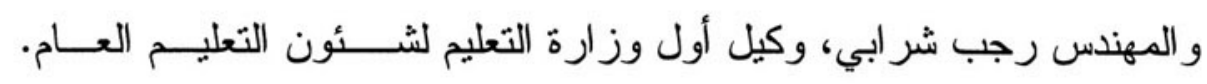

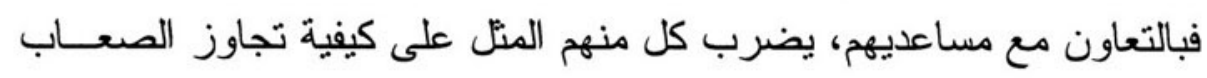

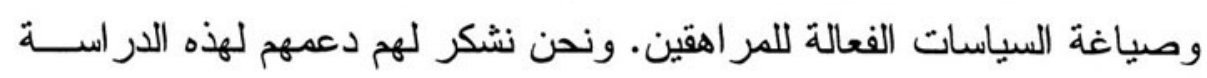

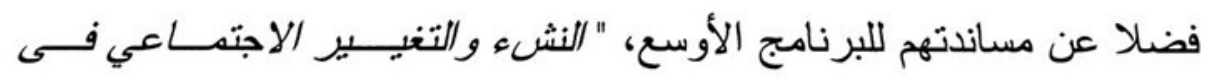

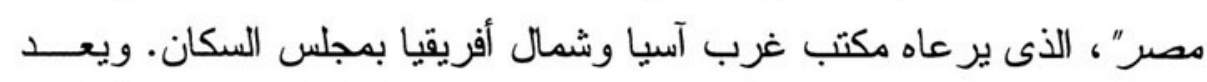
هذا الكتاب الأول فى سلسلة كتب حول هذا الموضوع. وسيظهر قريباً تثرير وناه حول نتائج مسح قومى عن النشء و الو الدين فى مصر . لاول

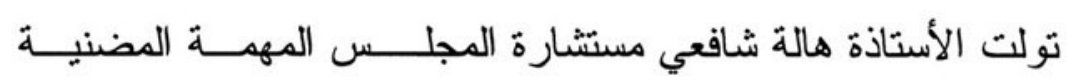

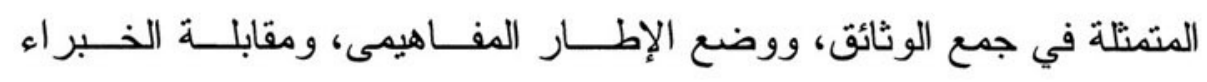

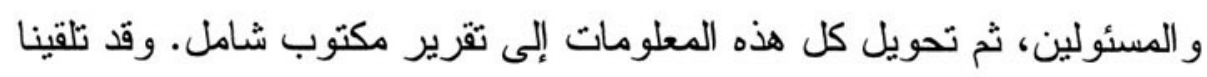

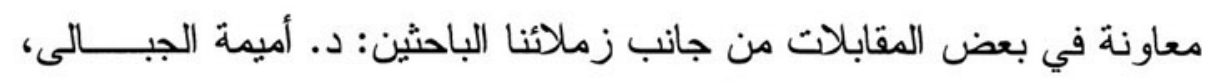

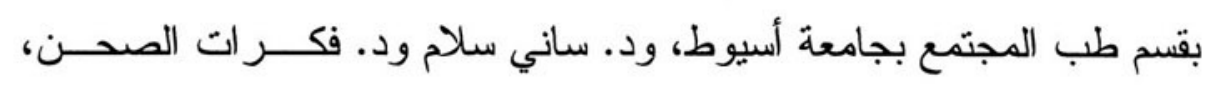
بالمعهد العالي للصحة العامة بجامعة الإسكندرية.

ونتوجه بالشكر كذلك إلى سارة بخــاري وســـوزان لــي ومشـيرة

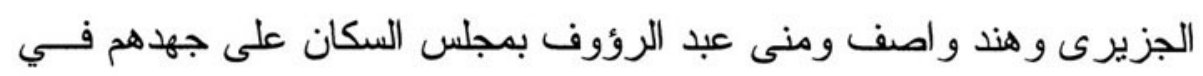




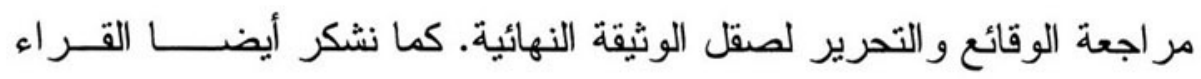

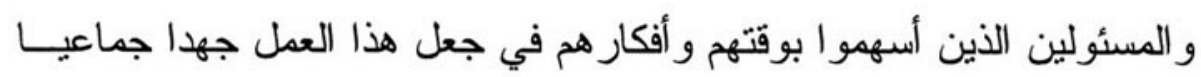
بحق.

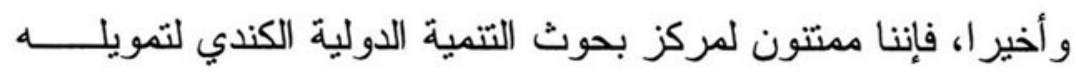

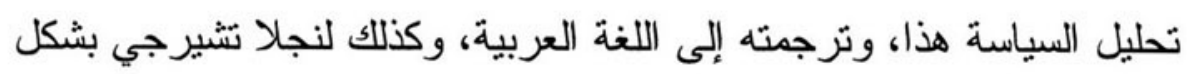

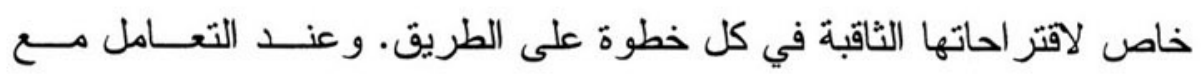

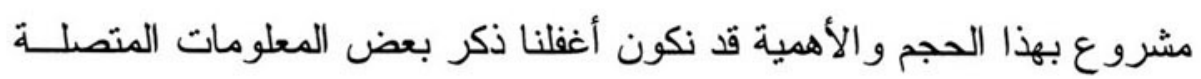

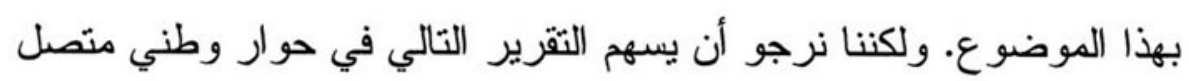
حول سياسات تحسين حياة النشء في مصر .

$$
\text { باربار إبر اهيم }
$$

المدير الإقليمي لمجلس السكان الدولي

في منطقة غرب آسيا وشمال أفريقيا

القاهرة، نوفمبر 1991 


\section{خلاصة}

رغم أنهم يشكلون حوالى ربع سكان البلاد، فإن المر اهقين أو النشه

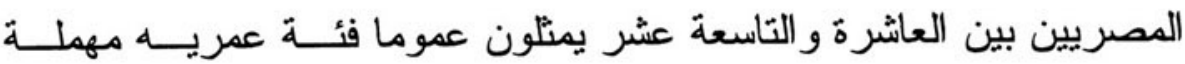

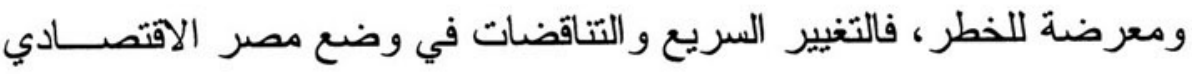

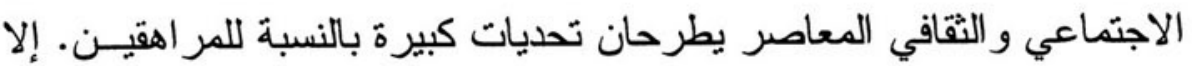

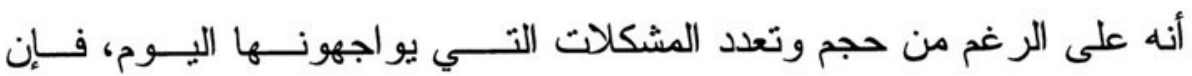

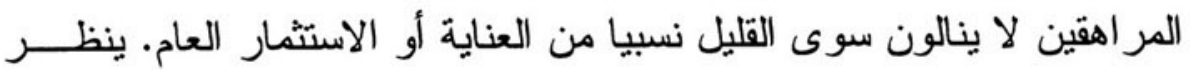

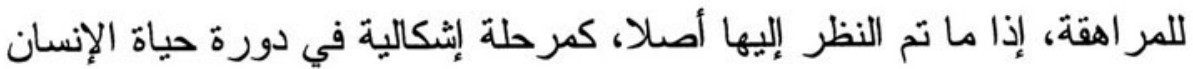

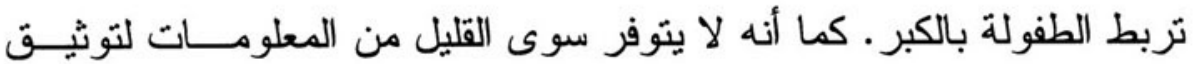
الحالة الر اهنة لهذه الفئة العمرية واحتياجاتها.

إن العجز عن تلبية احتياجات المر اهقين له ثمن باهظ. تسنطيع الدولة

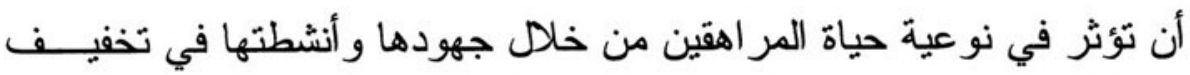
الفقر، وتوليد الوظائف و التدريب علـــى المــهارات، و التعليــ، و الخدمــات

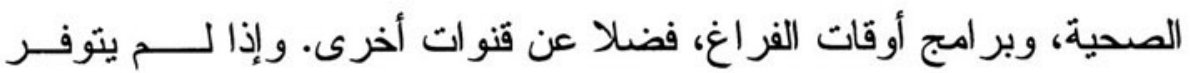

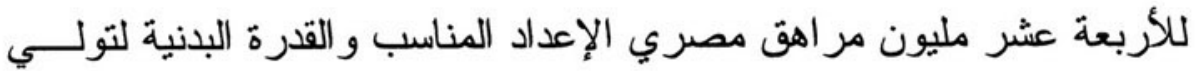
المسئوليات الإنتاجية و الإنجابية في المستقبل، فإن الثمن سيكون باهظا بالنسبة

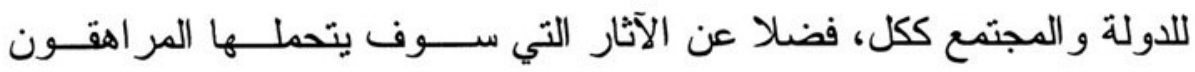

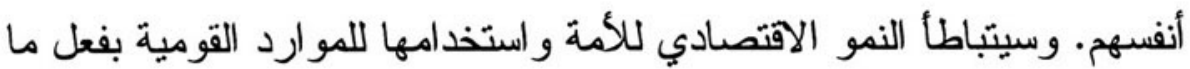

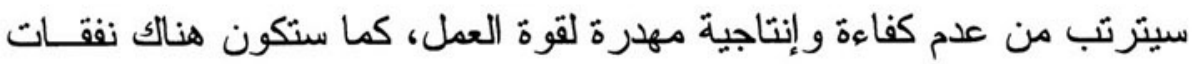
باهظة تتمثل في الإجراءات العلاجية متل محو أمية الكبار ، وتوفير الخدمات

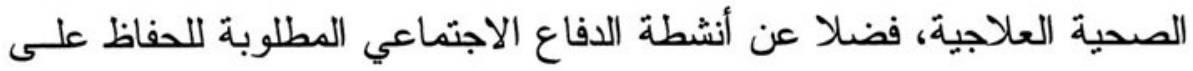

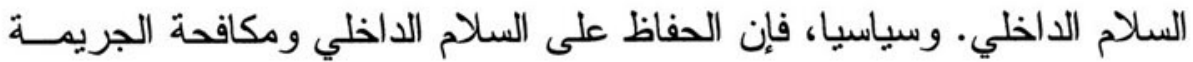
و التطرف يبدأ بالسياسات الخاصة بالشباب التي تعظم تقدير قيم التعبير عــن فئن 
الذات، و التعددية، و الطوعية، و الهوية الوطنية، وتسهم بالتالي فــي تحسـين الممارسة و المشاركة الديمقر اطية.

تلخص هذه الوثيقة نتائج عرض لسياسة الدولة في مصر فيما يتصل

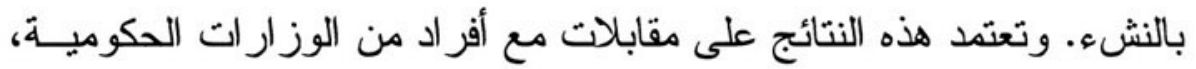

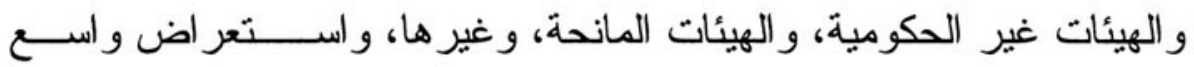
لوثائق السياسة المعنية. وقد تم استعر اض سياسة إحدى عشر وز ارة وعــد ولد

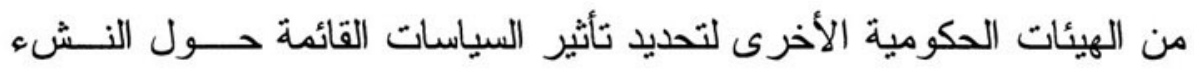
وتحديد القضايا الهامة التي تستحق مزيدا من العناية و الجهد.

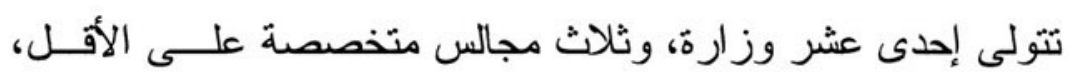
ولجنة داخل مجلس الشعب، المسئولية الرسمية عن تلبية احتياجات المر اهقين

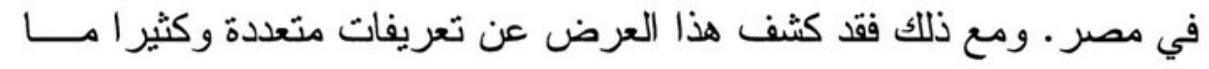

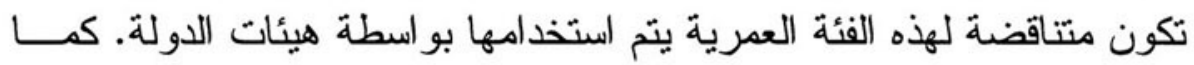

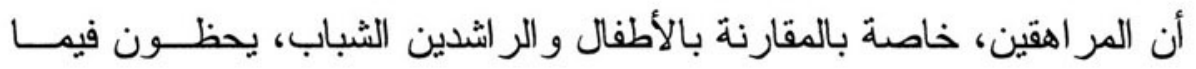

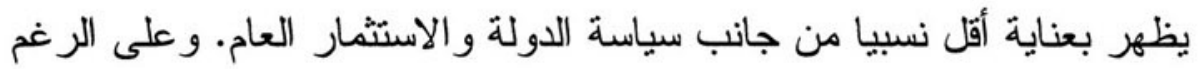

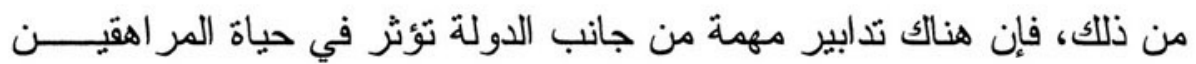

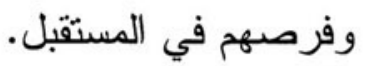

التعليم: ينص الدستور المصري على التعليـــم الأساســي الإلزامــي

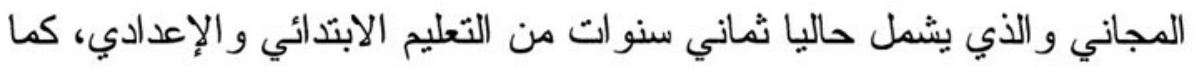

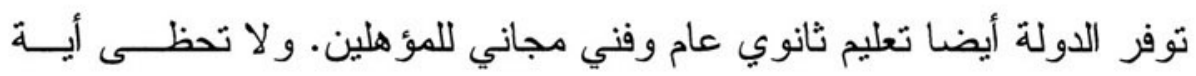

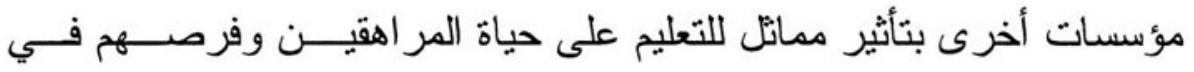
المسنقبل. إلا أن هذا العرض أظهر عددا من من المشكلات تحتاج لعناية متز ايدة من الدولة. وتتضمن هذه المشكلات تفاوتات إقليمية وأخرى تتعلق بالنو ع في 
القيد في التعليم، ومدى صلة المنهج التعليمي بالو اقع الاقتصـــادي، وقضايــا

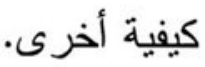

الصحة: بوفر نظام التأمين الصحي على طلبـــة المـــارس الخدمــة

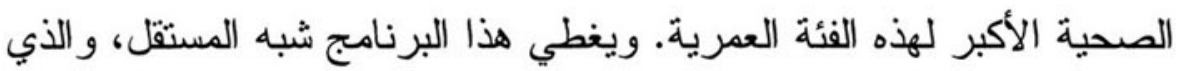

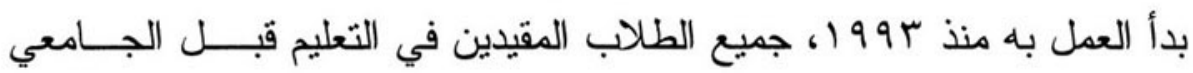
مقابل رسم سنوي رمزي. ويتعين على المر اهقين غير المقيدين في المدارس،

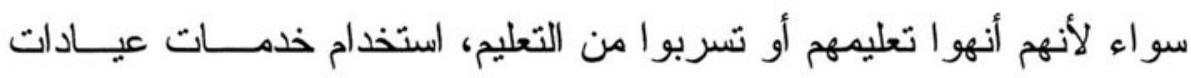

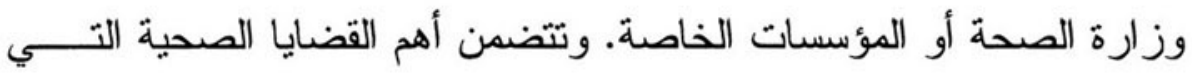

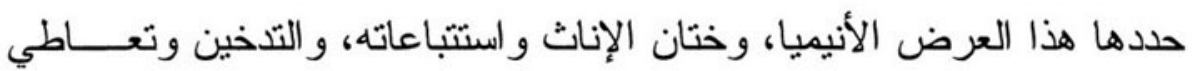

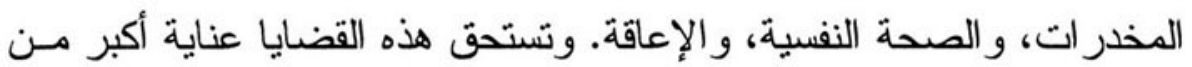

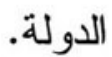

الزواج والصحة الإنجابية: الصحة الإنجابية للمر اهقين وزواجهم من

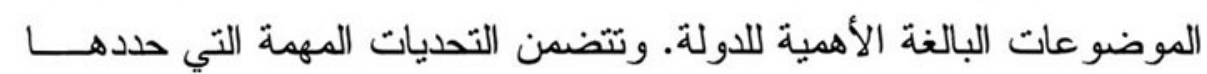

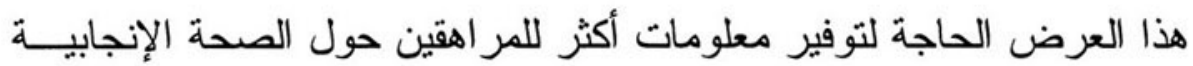

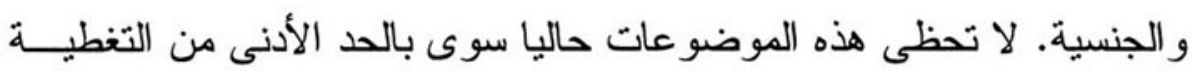

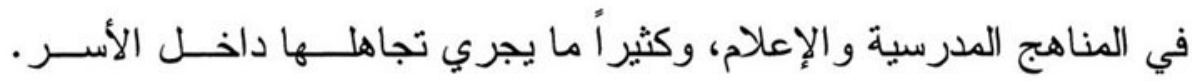

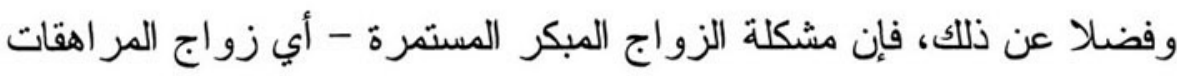

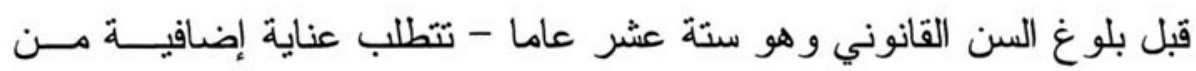
الدولة بسبب المخاطر الجادة التي يمثلها الحمل المبكر ، فضلا عن الخســائر

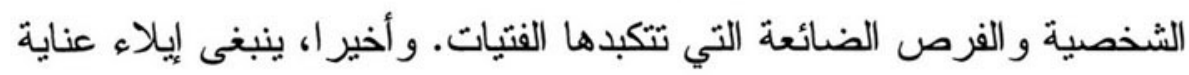

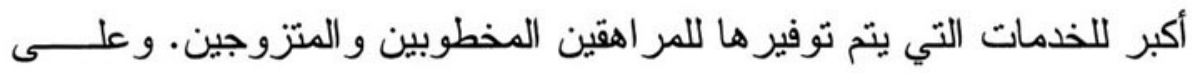

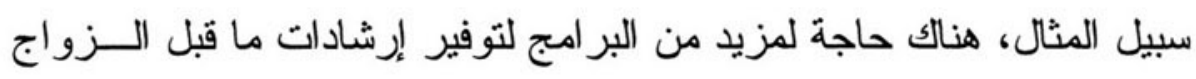


للمخطوبين، و هناك بعض الأدلة على أن المر اهقيــنـن المــتزوجين يجــدون صعوبة في الحصول على وسائل منع الحمل حتى إنجاب المولود الأول. العمل والتوظبف: يطرح عمل المر اهقين وبطالتهم في مصر اليــوم

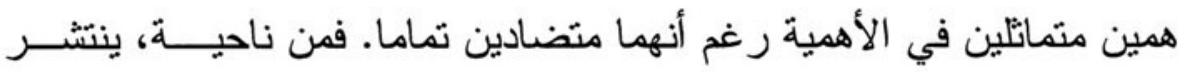

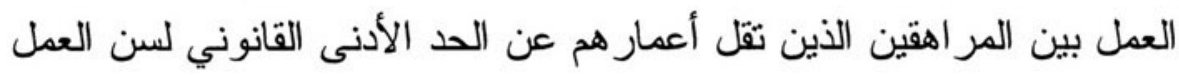

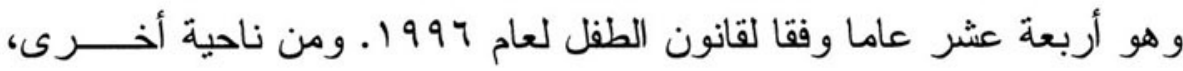

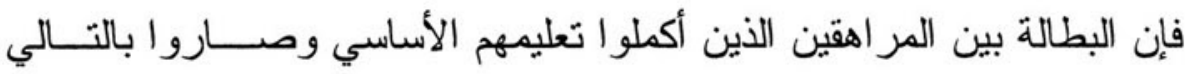

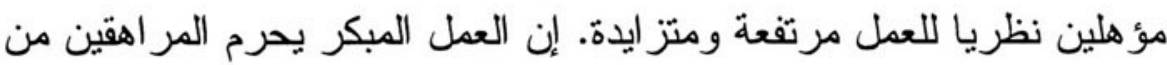

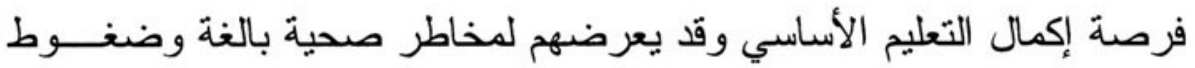

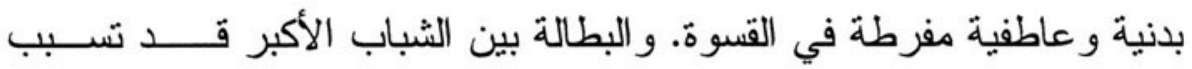

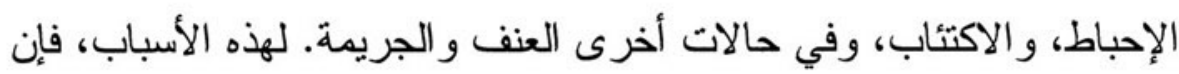
سياسة الدولة بالغة الأهمية من أجل مواجهة ولاتك الهرى الهموم.

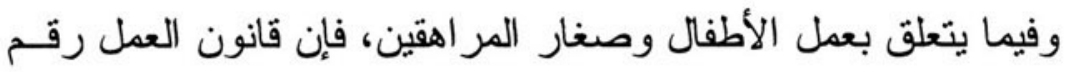

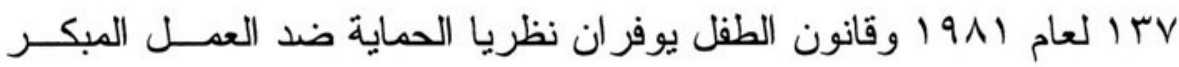

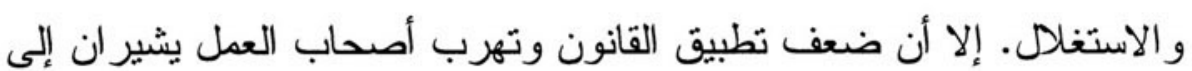

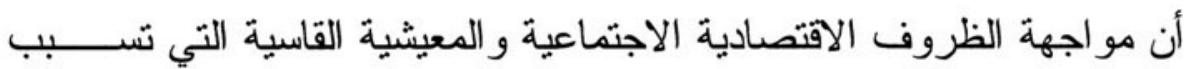

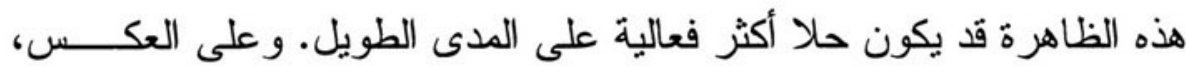

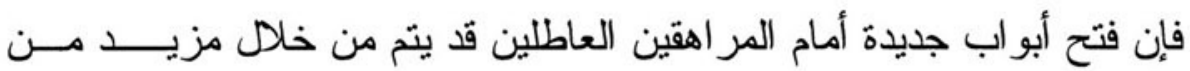

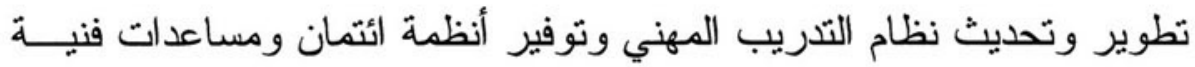
مناسبة من أجل تشجيع روح الاستثمار و المشروعات الصغيرة.

وقت الفراغ واستتباعاته: إن أنثطة وقت الفر اغ عامل مهم في حيـاة المر اهقين، وهي إما تسهم في نضجهم ورخاءهم أو تعرضهم لتأثير ات سلبية. 


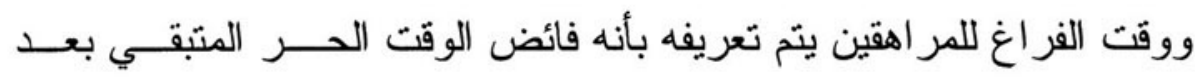

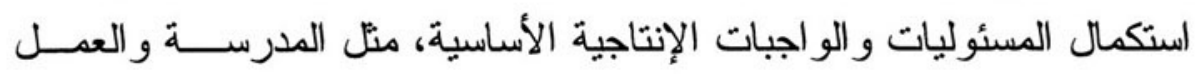
وتلبية المسئوليات العائلية ورعاية الأطفال بالنسبة للمر اهقين المــزتوجين. لا ينوفر سوى القليل نسبيا من المعلومات و الإحصائيات حول نمط اســــتغلص وقت الفراغ بو اسطة المر اهقين في مصر • ومع ذلك، فإن تحليل سياسة الدولة حيال وقت فر اغ المر اهقين يظهر توجهين كامنين، غير معلنين. التوجه الأول

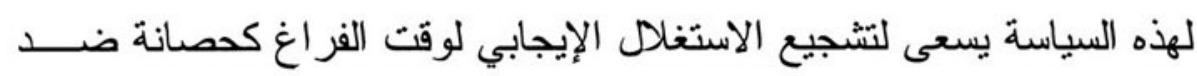
الانخر اط في أنشطة غير لائقة. يتضمن ذلك الرياضة والأنشطة الثقافية التي تز عاها الدولة. ويمكن أن يتم توجيه الجهود المستقبلية نحو تقليل التفاونـــات الحالية في الحصول على التسهيلات الرياضية و الثقافية. أما التوجه الثـــاني فيسعى لمكافحة الاستخدام السلبي لوقت الفراغ من خــــله در اســـة وكبــح و عقاب وتقويم سلوك الأحداث. و تثتضمن المجالات التي تحتاج لمزيـــد مــن

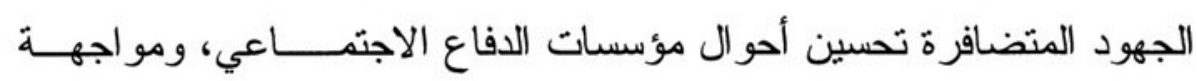

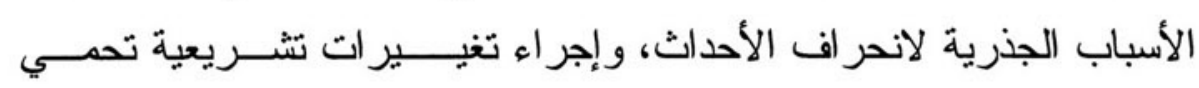
المر اهقين من استغلالهم في أنشطة إجر امية.

تبين هذه الدر اسة أن المشكلات و التحديات التي تواجــــه المر اهقيــن متعددة وهائلة وفي الأغلب معقدة. وتظهر الدر اسة أيضـا أن سياسة الدولـــــة تلعب دور ا محوريا في مو اجهة تلك القضايا، وهــــي (أي الدر اســة) تـبرز

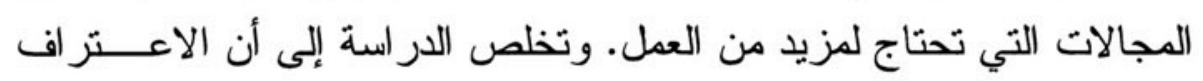
الرسمي بهذه الفئة العمرية المهمة من خلا تعريف موحد هو أمر ضروري

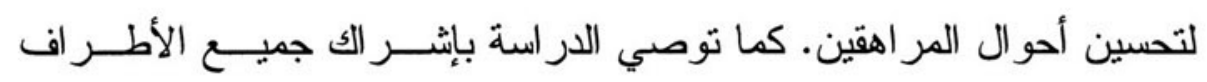

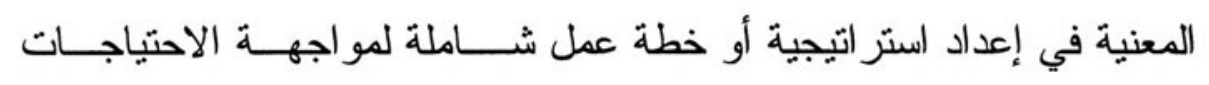
و التطلعات الخاصة بالمر اهقين. سيكون من شأن منل هذه الاستر اتيجية وضع 
المر اهقين في صدر جدول أعمال التنمية في مصر ، وحشد الالتزام السياسـي الضروري، وتعبئة الموارد المالية اللازمة. 


\section{مقدمة}

حتى انعقاد المؤتمر الدولي للأمم المتحدة حول السكان و التتمية فـــي القاهرة في ع9 19، كان الاهتمام العالمي بالنشء لا يز ال في طور الطفولـة.

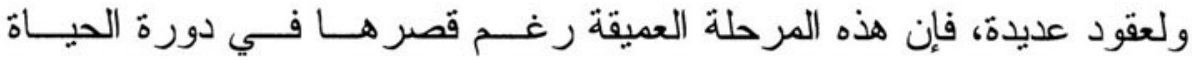
الإنسانية تعرضت لإهمال كبير من جانب الو الدين و المجنمع وصناع السياسة على حد سو اء. إلا أن الاهنمام الدولي قد تكثف خلال المؤتمر الدولي للسكان و التتمية وتم خلق الزخم اللازم لمواجهة احتياجات وتطلعات هذه الثــــريحة السكانية المتنامية، و التي تعرف عامة بالأعمار من العاشرة إلــــى التاســعة عشر ـ دعا برنامج العمل الصادر عن المؤتمر الدولي للسكان و التتمية جميـع البلدان إلى التعزيز النشط لصحة ورخــــاء و إمكانيــات المر اهقيــن وتلبيـــة احتياجاتهم الخاصة. وتضمنت الاحتياجات التي تم تحديدها التعليم و التوظيف و الصحة و الإرشاد وخدمات الصحة الإنجابية العالية المستوى و التــأييد مــن جانب الأسرة و المجتمع. كما ناشد البرنامج البلــــدان حمايـــة النــشء مـــن التأثير ات الضارة للفقر و الإساءة.

عالميا، اتخذت حكومات ومنظمات غير حكومية عديدة المبادرة فـي تعزيز رفاه ورخاء المر اهقين. فعلامات الإنذار المتمنثة في تز ايد الإصـابــــة بفيروس نقص المناعة المكتسبة/الإيدز بين النشء، ونز ايد معدلات الحمــــلـلـ و الإجهاض بين المر اهقات غير المتزوجات، و التعاطي الوبــــائي للنيكونيــن

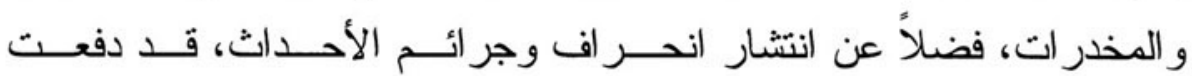
الحكومات لمر اجعة سياساتها. فقد تم إدخال اقتر ابات جديدة تشجع المزيد من الحوار ورفع الوعي بدلا من الاكتفاء بالتضييق على السلوكيات غير اللائقة.

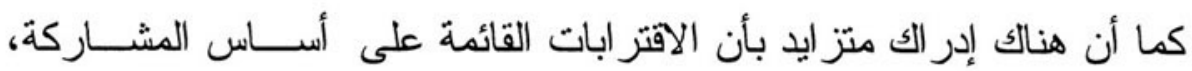
و التي تمكن المر اهقون أنفسهم وأولياء الأمور و المنظمات غير الحكومية جنبا 
إلى جنب مع الحكومات من اقتر اح الحلول وتتفيذ التدابير اللازمة لها، أكــثر فاعلية بكثير من الاقتر ابات الفوقية النقليدية.

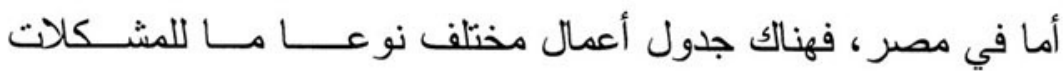

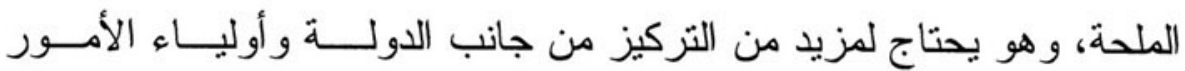

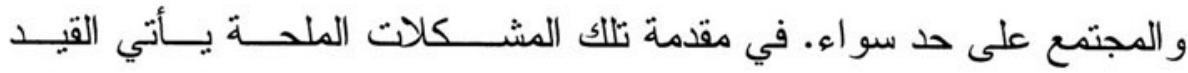

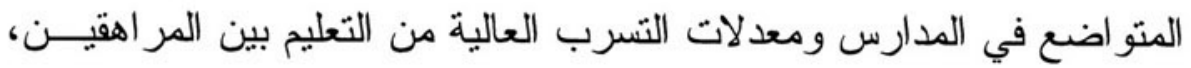
وخاصة الفتيات. مؤدى ذلك أن حو الى ثلث سكان مصر يعانون من الأميــة،

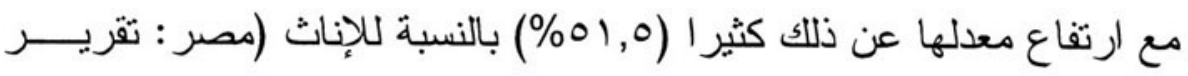

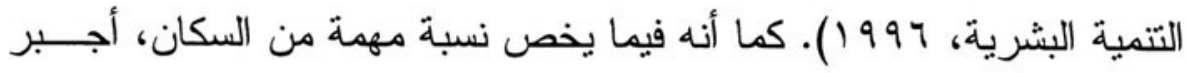

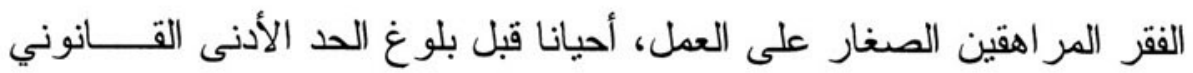

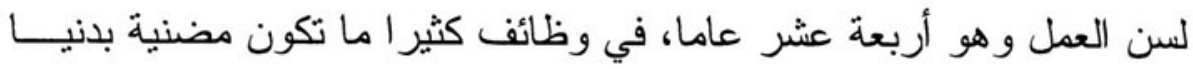
وخطرة. ومن ناحية أخرى، فإن معدلات البطالة العالية بين المر اهقين الذيـن فئن

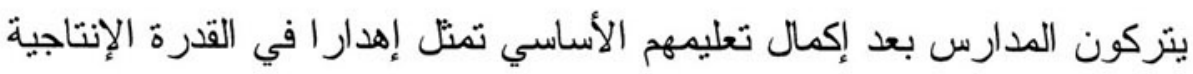

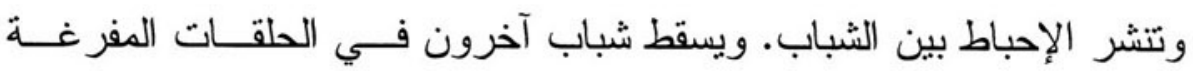

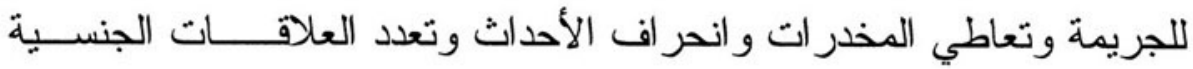
و التشدد العنيف. وفضلا عن ذلك، فإن الــزو اج و الحمـلـل المبكـر بالنســبة

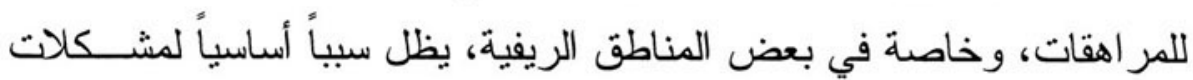

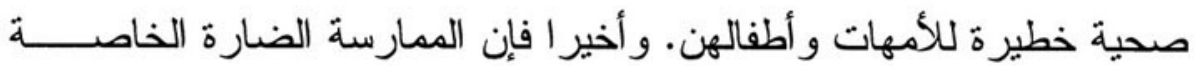

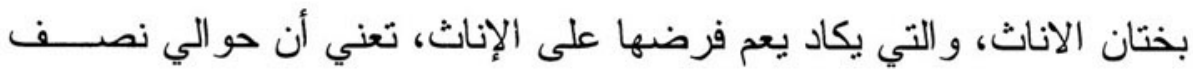

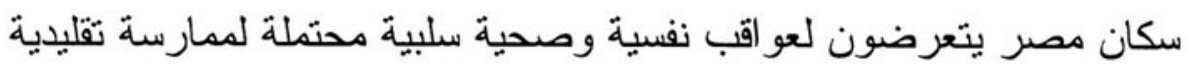


من الو اضح أن المو اجهة الجذرية لهذه المشكلات لا يمكن تأجيلــــها.

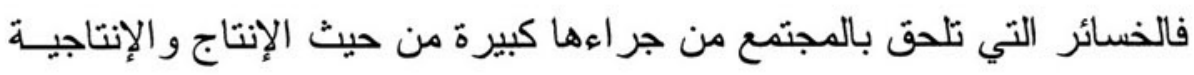

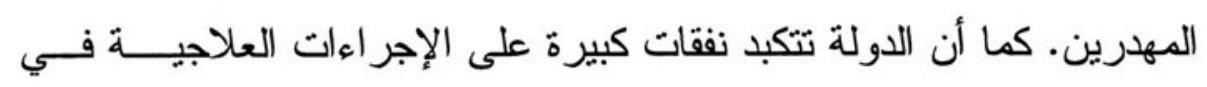
صورة بر امج محو أمية، و إعادة تدريب، ور عاية صحية علاجيــة، و إعـادة

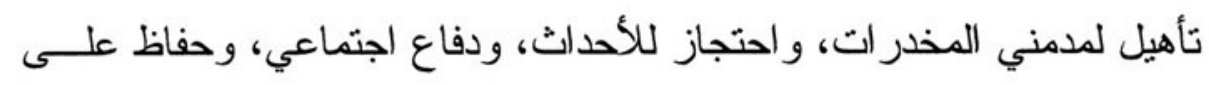

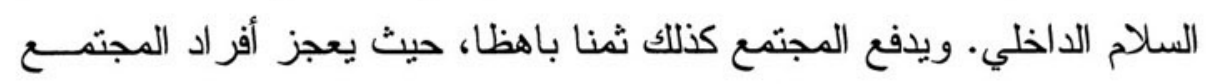
البالغين عن الوصول إلى أقصى قدر اتهم فى المستقبل.

وفضلا عن ذلك، فإن التحديات التي تطرحها المستويات المــــز ايدة

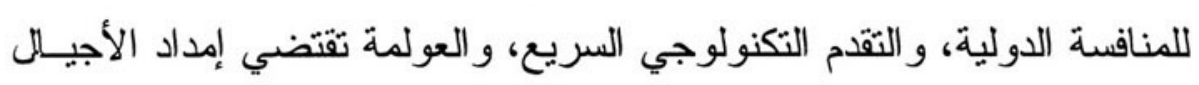

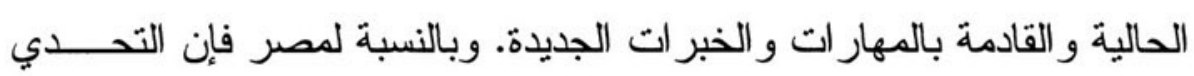

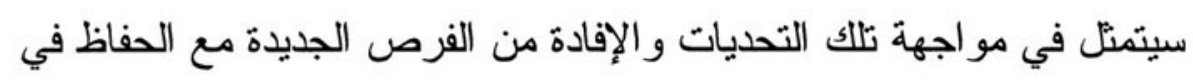
الوقت ذاته على هويتها الوطنية ودينها وتر اثها الثقافي. و أخير ا، بستحق المر اهقون العناية من جانب الدولة لكونهم يثـــكلون

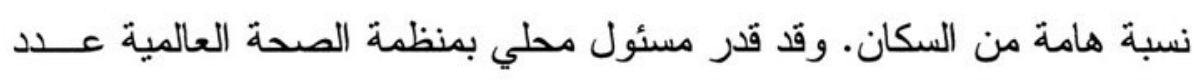

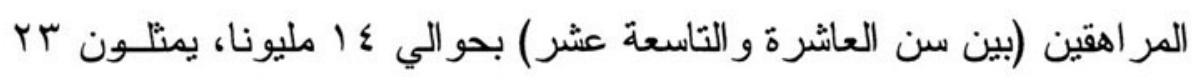

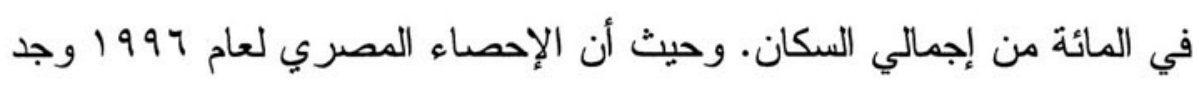

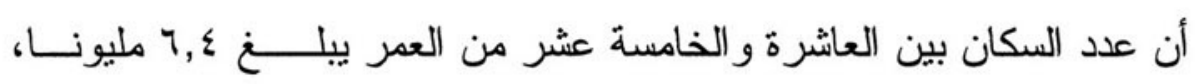

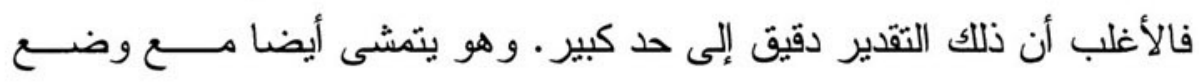

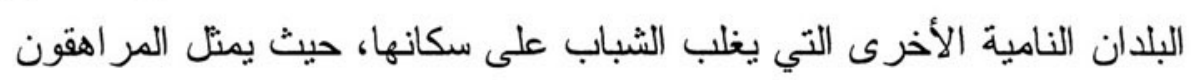

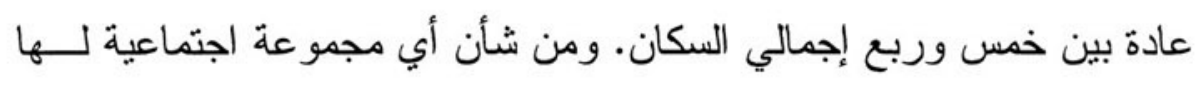

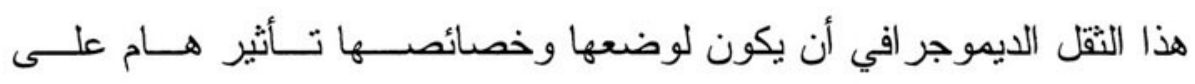


المجتمع المصري ككل. تُنتحق احتّاجات المر اهقين الخاصـــــة إذن عنايـــة

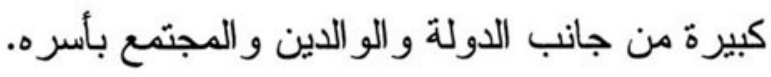

\section{الغرض و النطاق و المنهج}

لهذه الدر اسة ثلاثة أغراض: أو لا، التعرف على كيفية تعريف وفـــهم

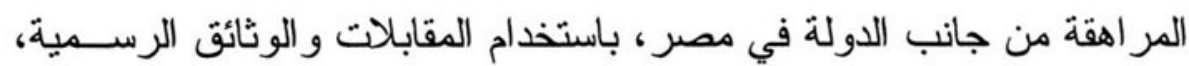

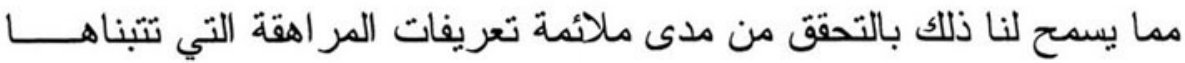

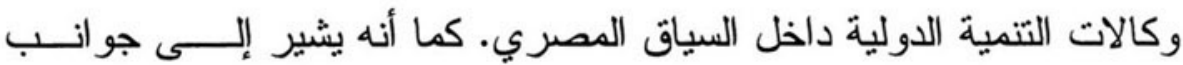

الارنباك أو التناقض في السياسات التي يتعين مو اجهتها في المستقبل. ثانيــا،

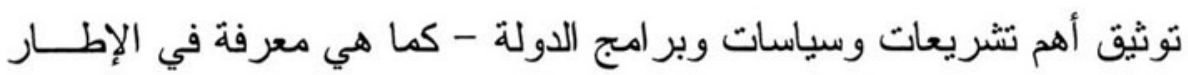

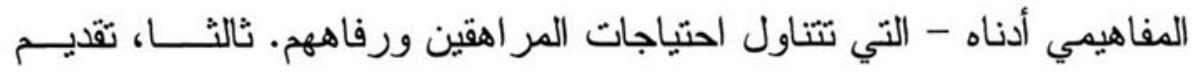

توصيات على مستوى السياسات بشأن مبادر ات و اعدة قابلة للتنفيذ، والإشارة

إلى مجالات ذات أولوية قصوى تحتّاج لمزيد من العناية و العمل المنضافر .

النطاق: يتسم العقد الذي يربط الطفولة بالكبر بتغيرات عميقة بالنسبة

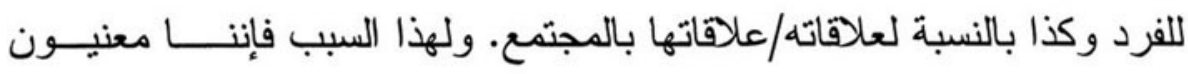
بالكيفية التي تعمل بها الحكومات على دعم تلك المرحلة من الحياة. ويكاد كل مجال من مجالات السياسات يمس المر اهقين بطريقة أو بأخرى.

تتضمن مجالات الاهتمام البديهية السياسات المتعلقة بالصحة العامــة

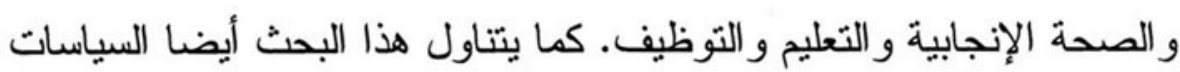

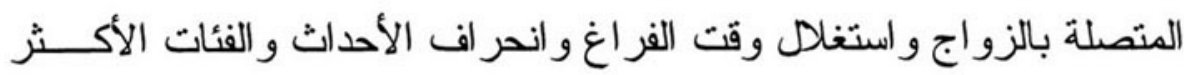

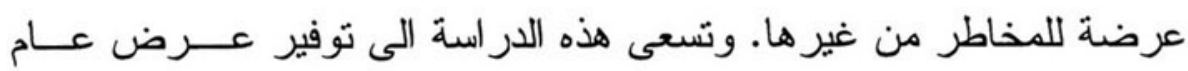

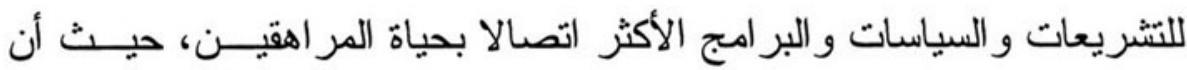

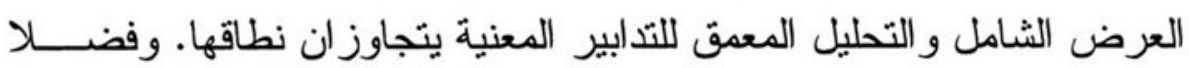




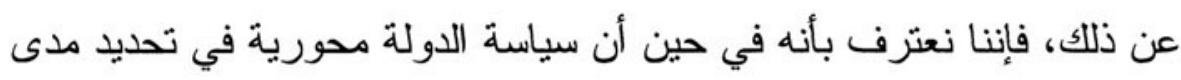

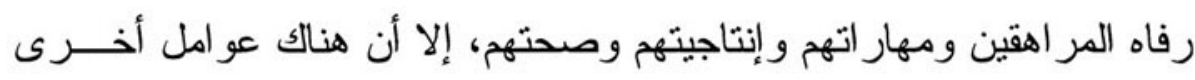

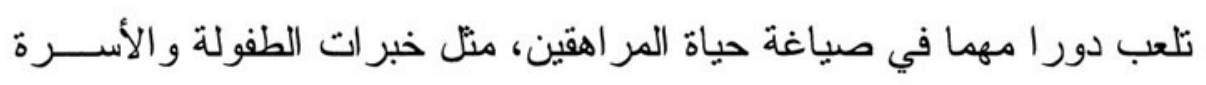
و الأقر ان و الخلفية الاقتصادية الاجتماعية و الدين و الثقافة.

تستعرض هذه الدر اسة السياسة داخل إطــــار ســـاقها الاقتصــادي

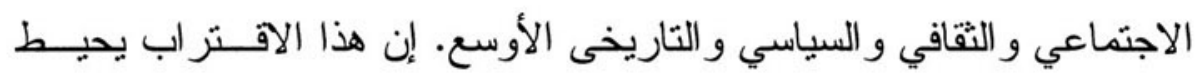

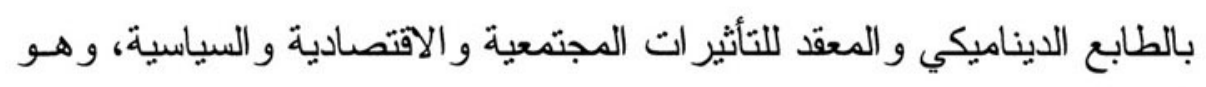

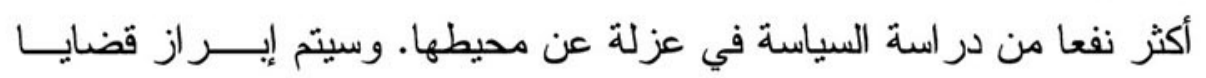

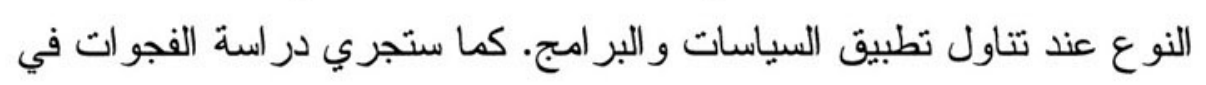
التشريعات و السياسات و التدابير بهدف اقتر اح مجالات العمل ذات الأولويـــة.

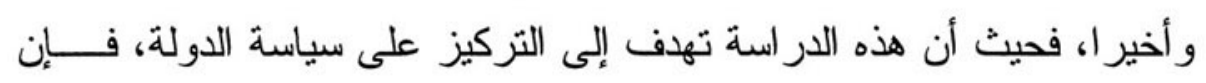

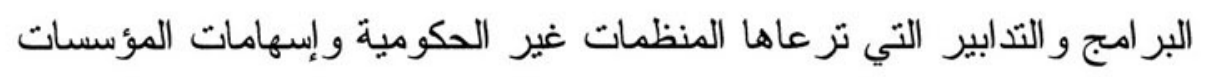
الدينية و البحثية و الأكاديمية تخرج عن دائرة التحليل.

\section{المنهج}

لكي يتسنى التوثيق الدقيق لسياسة الدولة الر اهنة حيال المر اهقيـــن،

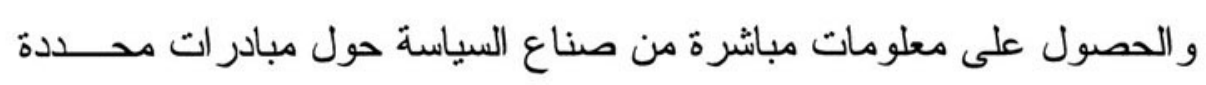

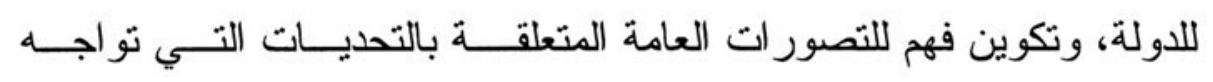

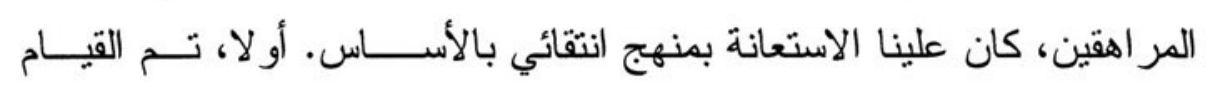

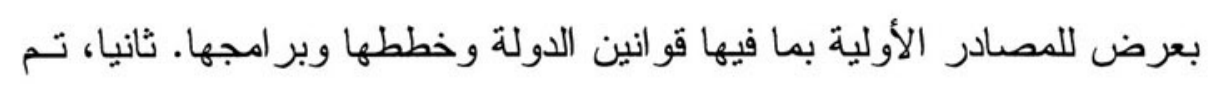

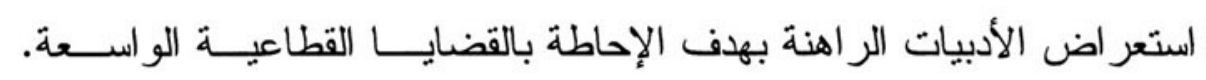

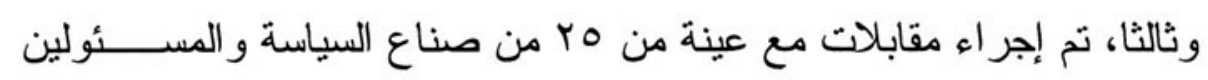

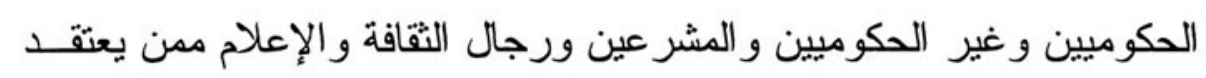


أنهم قرييون من ساحة المر اهقة. استهدفت هذه المقابلات فهم الطريقة التــي

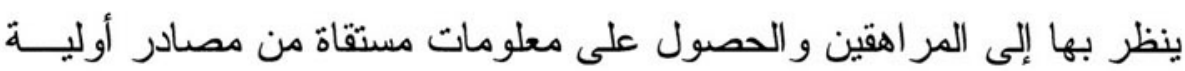

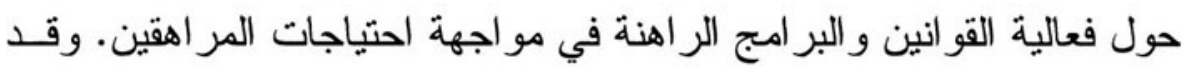

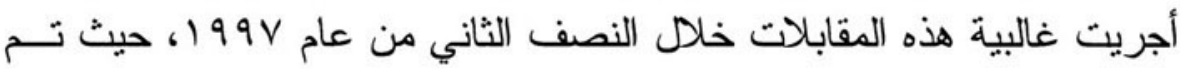

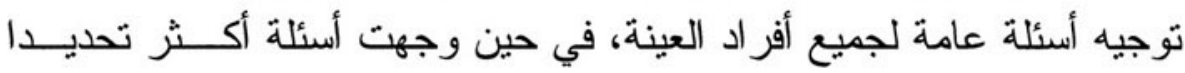

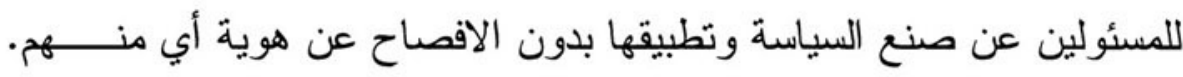

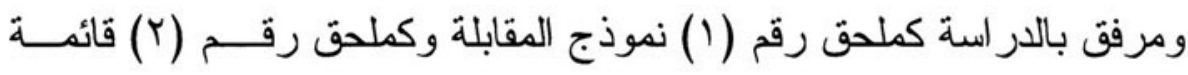
بالأشخاص الذين تم استشارنهم.

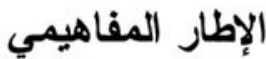

تعريف المر/هقة

المر اهقة مرحلة قصيرة نسبيا لكنها عميقة من حيث تأثثر ها في دورة

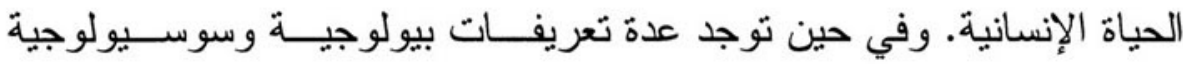
ونفسية وثقافية للمر اهقة، فإنه لا يوجد نعريف و احد متفق عليه دوليا. ويزداد

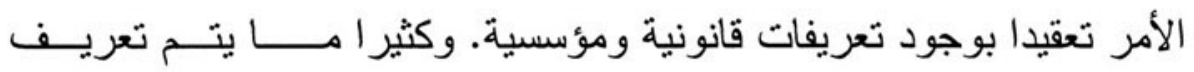

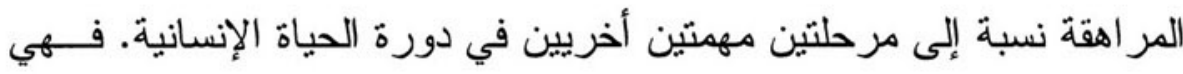
تعقب الطفولة وتسبق النضج. إن هذا الاقتر اب من المر اهقة كمرحلة انتقاليــة

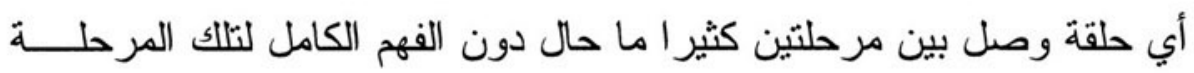

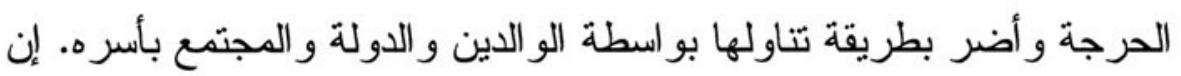

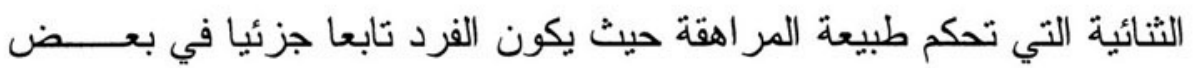

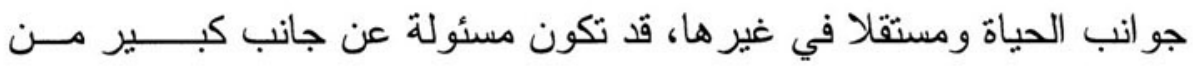

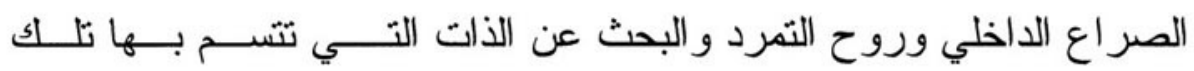


المرحلة. و هكذا فبخلاف التغير ات البذنية المر افقة لهذه المرحلة، هناك أيضـا

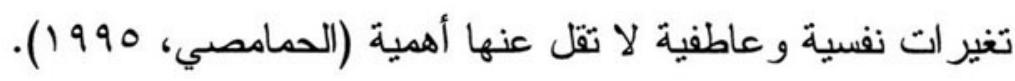
يبدو أن هنالك أقصى قدر من الاتفاق العام بشـــــأن تعييــن الحــدود

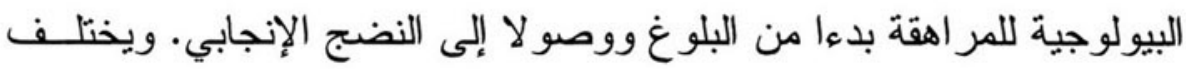

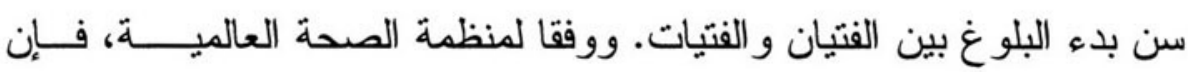

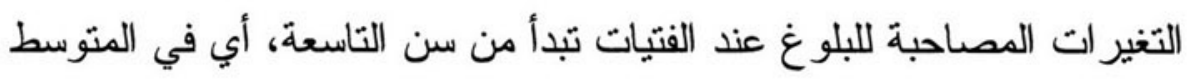

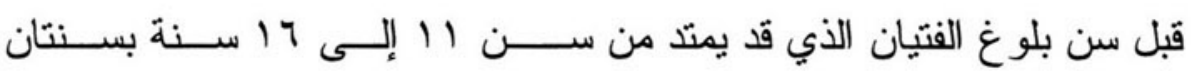

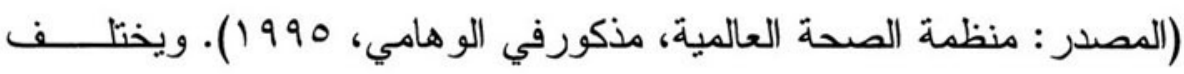
بدء البلوغ أيضا وفقا لعو امل ور اثية وغذائية ومناخية.

و لأغر اض هذه الدر اسة، سيتم تبني تعريف منظمة الصحة العالميـــة

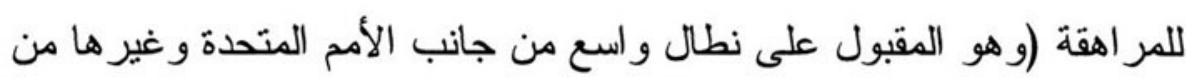

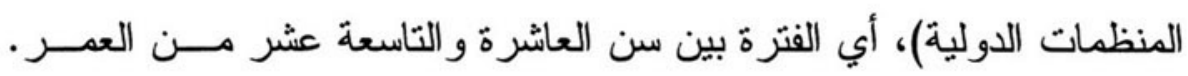

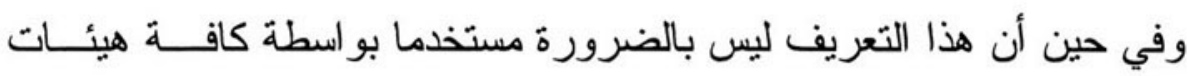

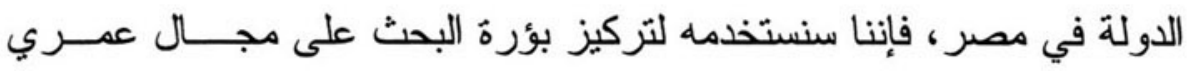

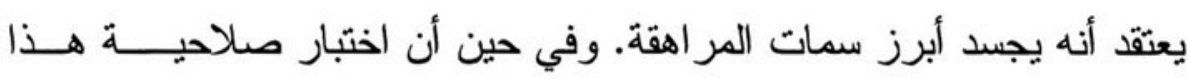

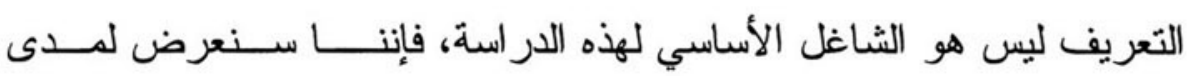

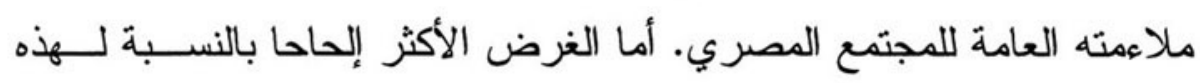

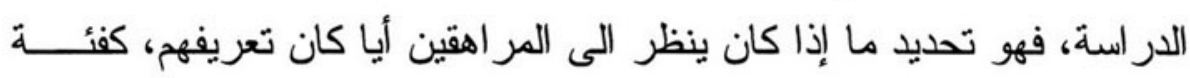

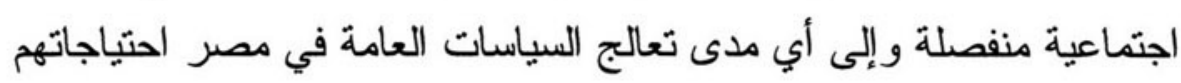
الخاصة. 
بصورة مجملة، يمكن تعريف سياسة الدولة بأنها البيانــات و الأدوات

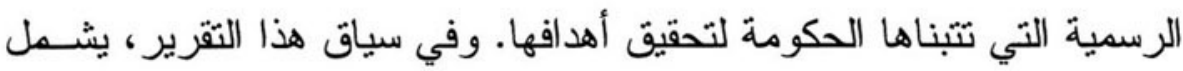

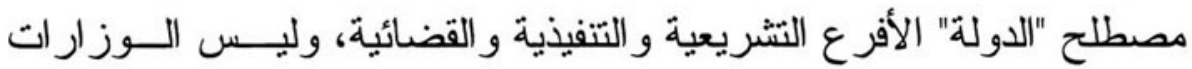

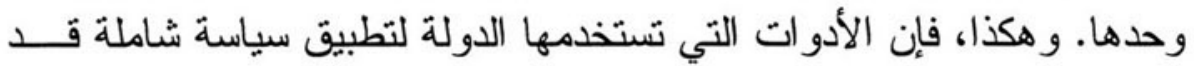

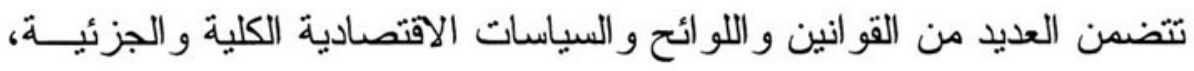

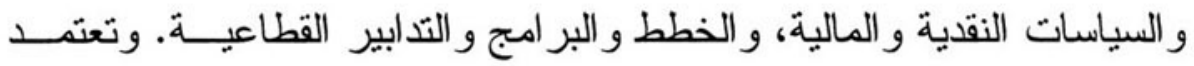

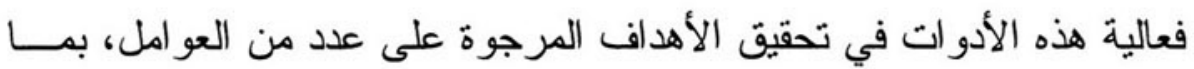

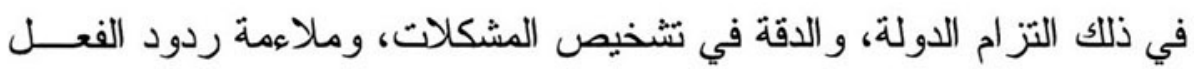

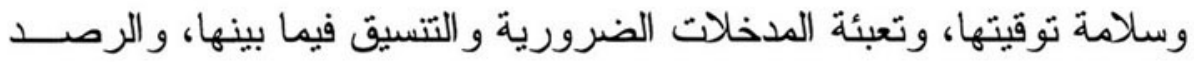

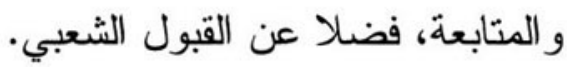
و لأجل أغر اض البحث الر اهن، يمكن تقسيم أدوات سياسة الدولة إلى

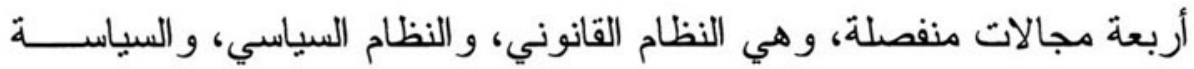
الاقتصادية، وميادين السياسة الأخرى.

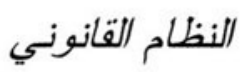
يعود النظام القانوني الحديث في مصر إلى منتصف القرن التاســــع عشر • وتطبق مصر قانونا مدنيا حيث يتمثل المصدر الرئيسي للتشريع فــي لـي

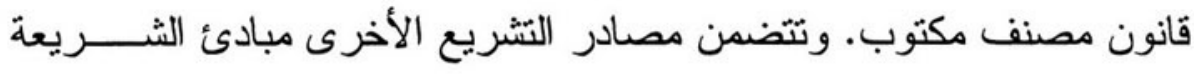
الإسلامية، و الأعر اف، ومبادئ القانون الطبيعي و العدل (ذو الفقار ، 990 (1). ووفقا لذو الفقار ، "في تز اتبية القوانين، يمتل الدستور الدرج الأعلى".

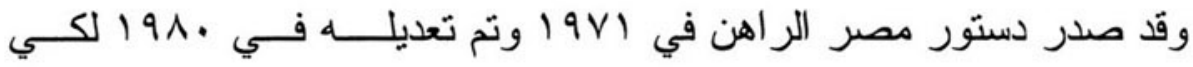
ينضمن الشريعة الإسلامية باعتبارها المصدر الرئيسي للنشريع. 
تغطي قو انين الدولة ونشريعاتها كل نواحي الحياة من الميــلاد إلــى الموت، وهي تحكم التفاعل الاجتماعي وكذا النشاط الاقتصادي. و لا تجمـــلـ

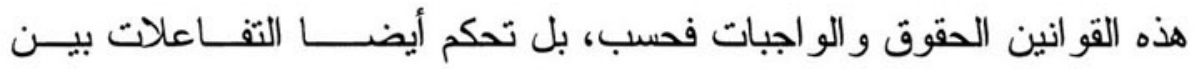

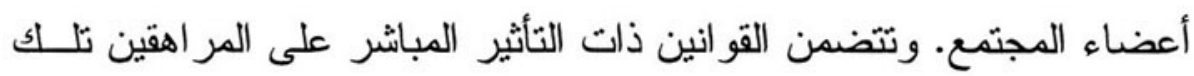

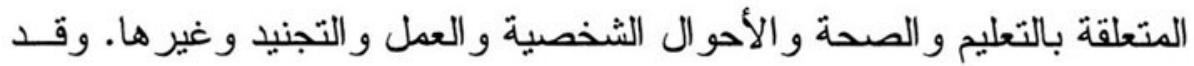

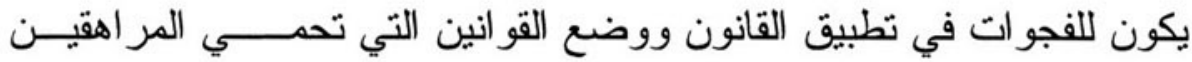

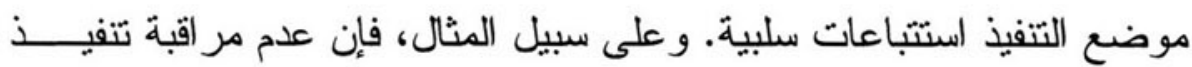
شرط الحد الأدنى لسن الزواج (سن 17 عاما بالنسبة للفتيات) يــــؤدي إلــى الزواج و الحمل المبكرين وتعقيدات اجتماعية وصحية بالنســـــة للمر اهقيـن و أطفالهم معا.

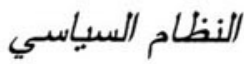
يمثل النظام السياسي وجها آخر للدولة له تأثيره علـــى المر اهقيــن. يخنص البرلمان المنتخب في مصر بوضع القوانين ومراقبة السلطة التنفيذية. وتحدد مستويات الممارسة الديمقر اطية وحريـــة التعبــير و التعدديــة مــدى المشاركة السياسية المسموح بها. و على سبيل المثال، يحدد النظام السياسي ما إذا كانت المظاهر ات الشعبية لطلاب الجامعات مباحة. وفي مصر فإن النظام السياسي، بالاشتر اك مع البنية التزاتبية للمجتمع و النظام التعليمي الذي يشجع الطاعة و الامنثال، يشكل المهار ات التي يطور ها المر اهقون وكذا الصفـــــات التي تحظى بتقدير هم، كما يبعث برسائل قوية بشأن الســــلـوك اللائــن فــي المجتمع (و اصف، 997 ( ). وتلعب هذه الرسائل بدورهـــــا دورا قويــا فــي تشكيل الاهنمام بالنظام السياسي و المشاركة فيه. 
تمارس السياسة الاقتصادية للدولة أيضا دور ا مهما، مباشر ا وغـــير

مباشر ، في صياغة حقائق الحياة اليومية بالنسبة للمر اهقيــن. فمـنـ خـــل تأثير ها على الأداء الاقتصادي، تؤثر السياسة الاقتصادية الكلية للدولة نـأثيراً

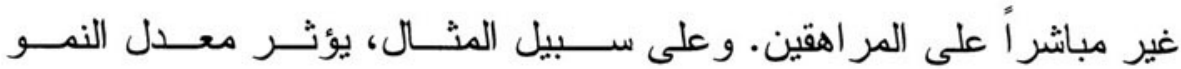
الاقتصادي في حجم فرص العمل المتاحة للشباب ونوعيتها. كما أنه يؤثـــــر على معدل التضخم الذي يحدد نفقات المعيشة وبالتالي مستوى معيشة الشباب وفرصهم في المستقبل. وفضلا عن ذلك، فإن البر امج الواسعة مثل برنــــامج

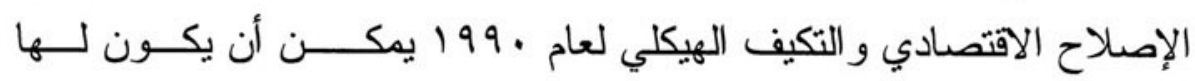
استتباعات مهمة بالنسبة للمر اهقين لأنها تحمل إمكانية إعادة صياغة مجمـلـ المجال الاقتصـادي. أما الإصلاحات التي يتم إدخالها مـــن خـــلم السياســـة النقدية و المالية، و الخصخصة، و الإصلاحات الهيكلية للقطاع العام و القطاعين المالي و التجاري، فإنها تغير كليا الفرص الاقتصادية المتاحـــــة للمر اهقيـنـ، حيث تخلق مناخا جديدا في الحاضر و المستقبل على حد سو اء.

ويمكن للسياسات التي تؤثر على دخل الأسر المعيشية أن نكون بالغة الأهمية بالنسبة لخلق فرص للمر اهقين. وتمثل الموازنة المالية إحـدى أدوات السياسات الكبرى هذه. فالضر ائب التي ينت تحصيلها على الدخل الثــــــي و الأرباح التجارية و السلع و الخدمات و الملكية و التجارة الخارجية تؤثر علـى عى دخل الأسر وبالتالي أيضا على مقدار ما ينفق على التغذية و الصحة و التعليــ و الحاجات الأساسية الأخرى. كما أن الإنفاق الحكومي علــى دعــم الغــذاء

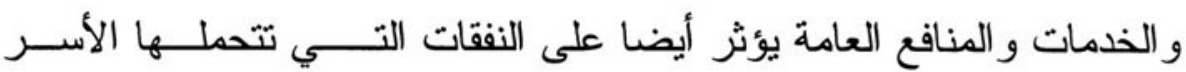
وبالتالي على رفاه المر اهقين. وتحدد السياسة النقدية معدل الفائدة الذي يحـدد 
بدوره مستوى الاستثمار وطبيعته (كثيف العمل أم كثيف رأس المال). ويؤثر ذللك على سوق العمل وبالتالي على فرص التوظف المتاحة أمام المر اهقين. وتحت مظلة السياسة الاقتصاديــــة الكليــة هنــاك مجموعــة مــن

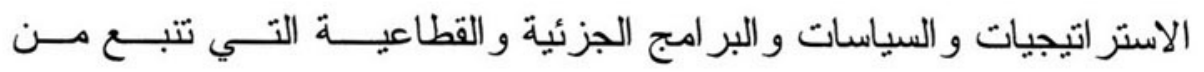

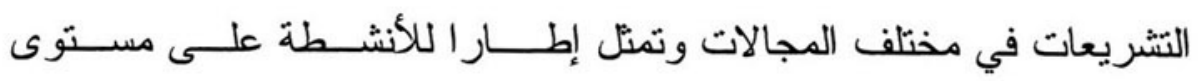

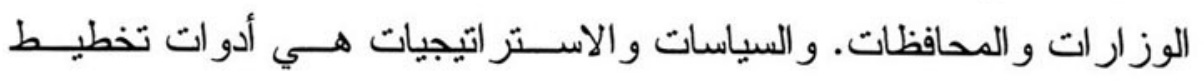

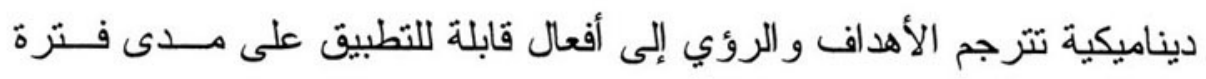

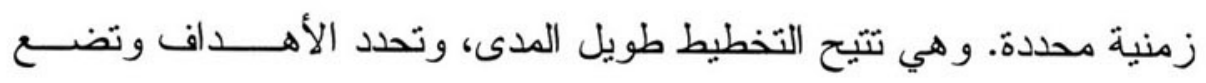

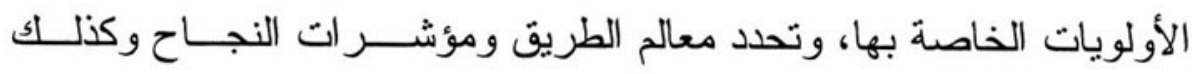

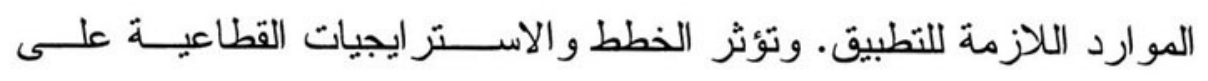

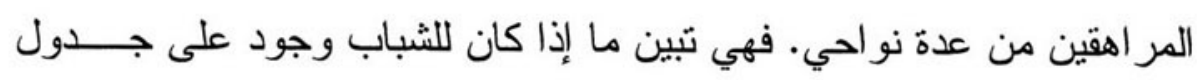

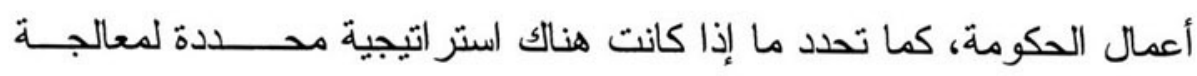
احتياجات تلك الفئة العمرية.

وتعد عملية التخطيط الاقتصادي أداة مهمة أخرى في مجال السياســة

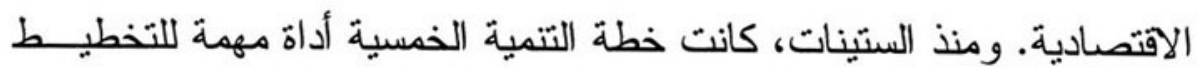

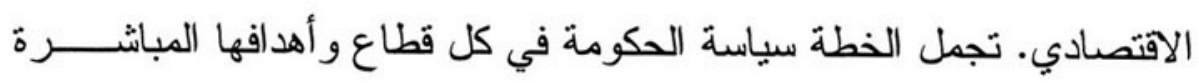

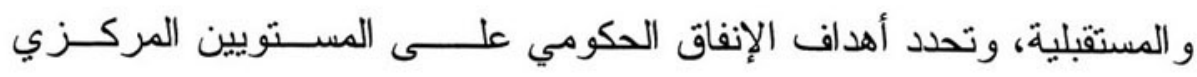

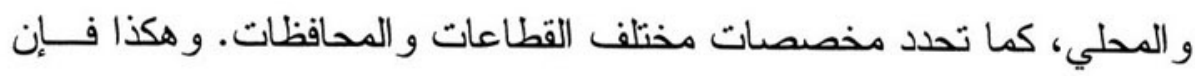

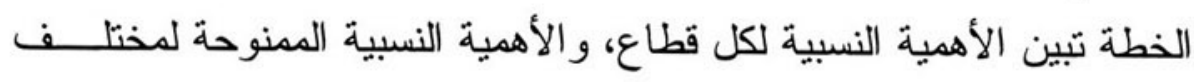

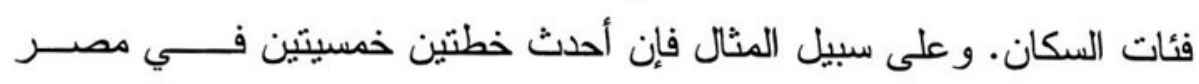

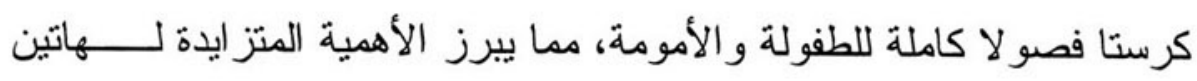


تؤثر الدولة على المر اهقين في طبيعة علاقتها بأطر اف أخرى، بمــــا

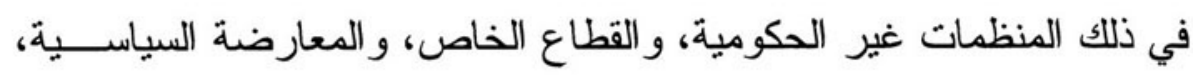

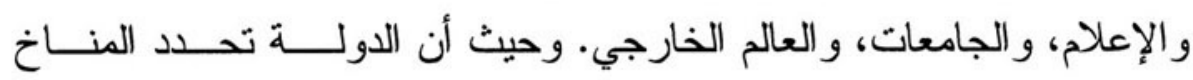

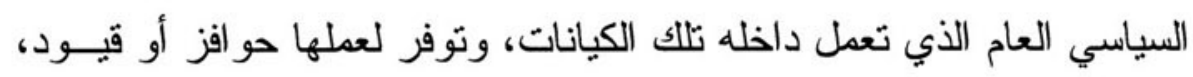

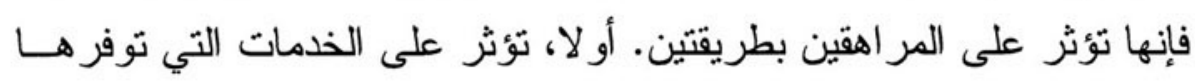

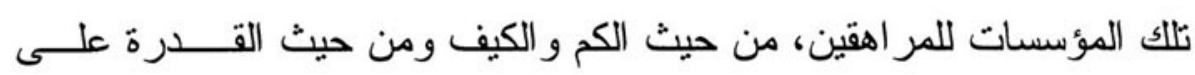

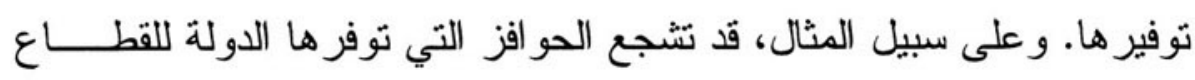

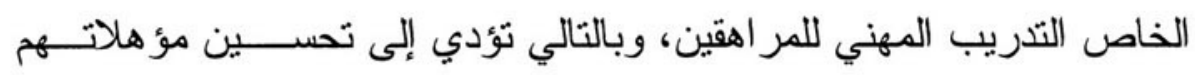

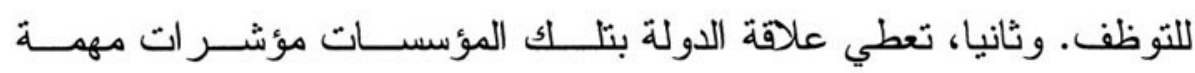

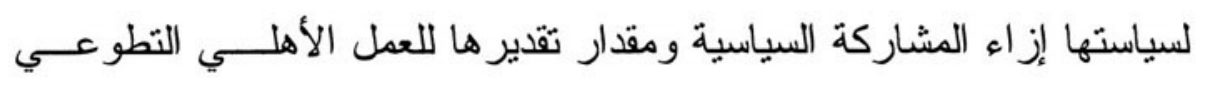

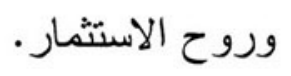

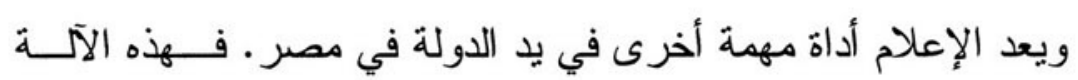

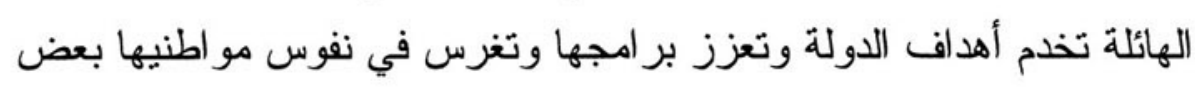

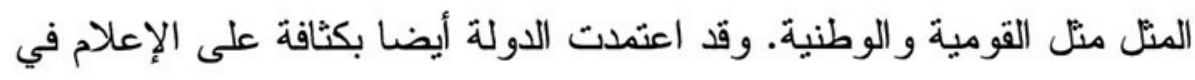

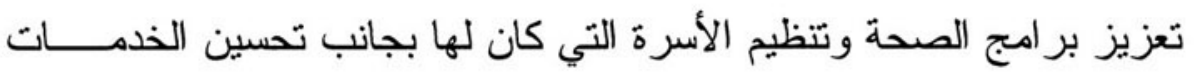

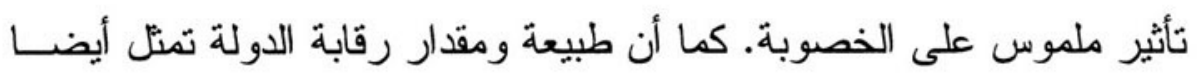

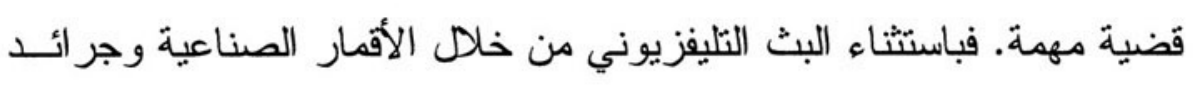

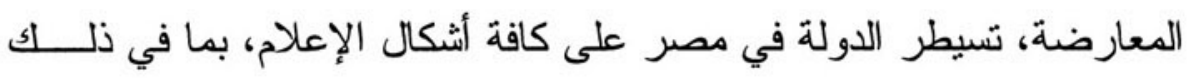
التليفزيون و الإذاعة و الجر ائد و السينما. 
إذا أردنا تعريفا عاما، فإن سياسة الدولة حيال المر اهقين هي مجمـلـ لهـل توجه الدولة نحو هذه الفئة العمرية. وقد تتجسد سياسة الدولة في خطة عملـل

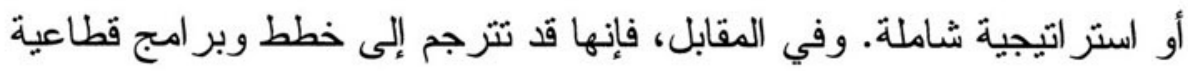

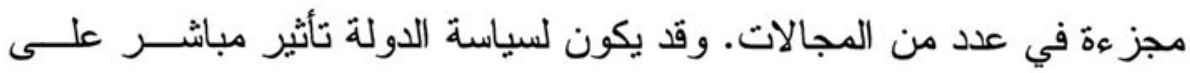

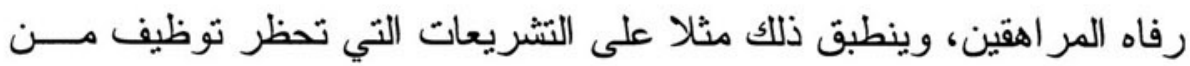

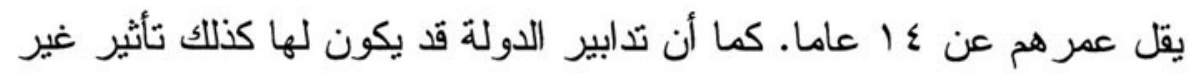

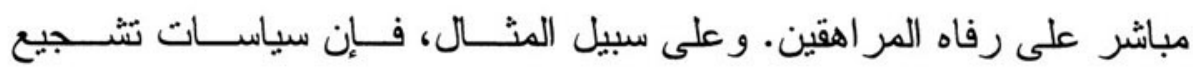

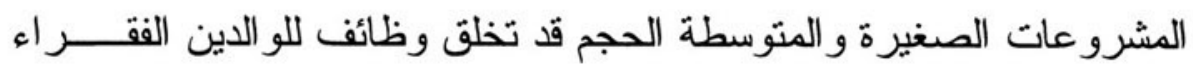

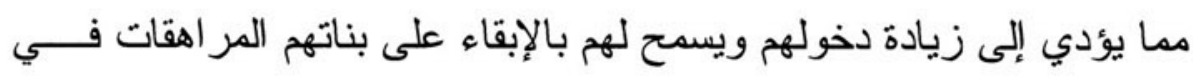

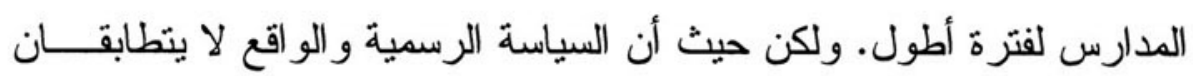

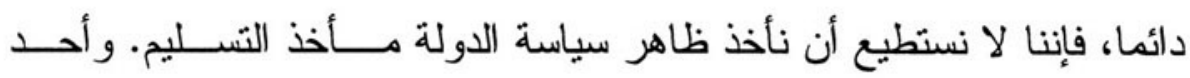

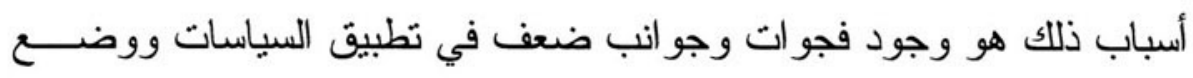

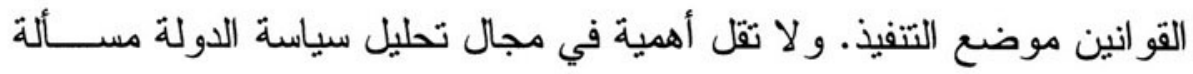
نقص الموارد الملاعمة أو البنى المؤسسية لتطبيق سياسة بعينها. وتستحق سياسة الدولة عناية خاصة لأنها تمس كافة جو انــب حيــاة

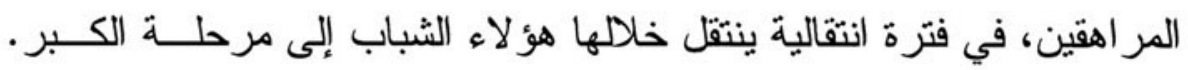
وتتخذ قنوات وآليات الثأثير عددا من الأشكال.

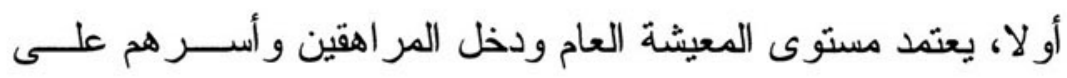

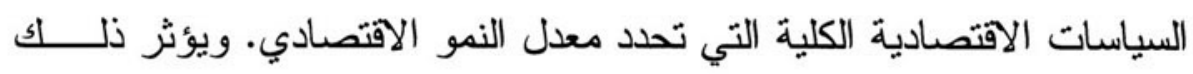

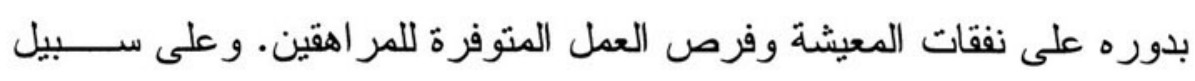

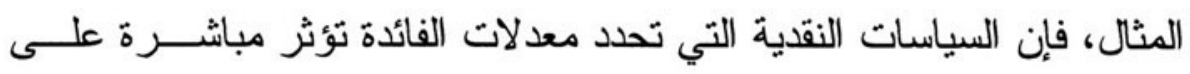


معدل الاستثمار ، الذي يحدد بدوره الطلب على عمل المر اهقين. ويتأثر عملـ

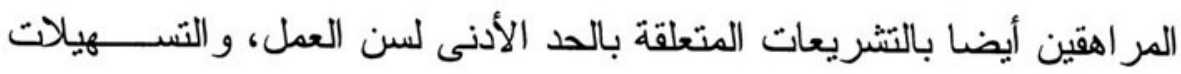

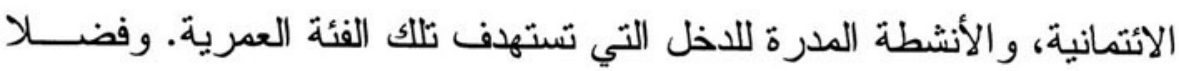
عن ذلك، فإن السياسات الاقتصادية الكلية تحدد توزيع الدخل بين المو اطنين.

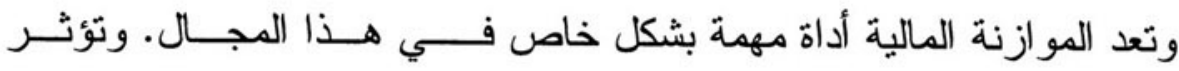

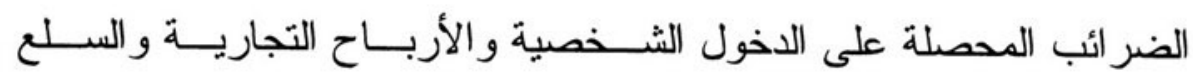

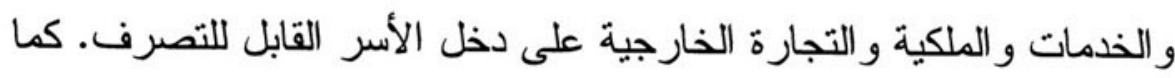

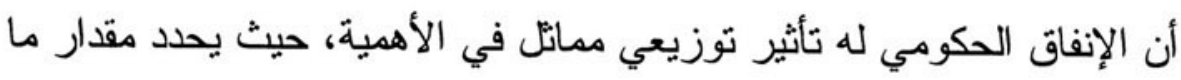

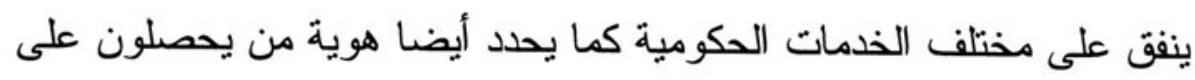
تلك الخدمات.

ثانيا، تحدد سياسة الدولة توفير الحاجات الأساسية للمر اهقين، بما في

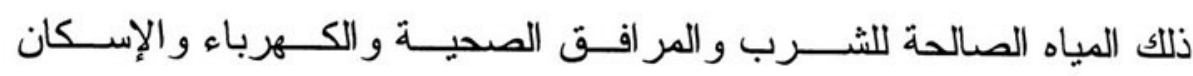

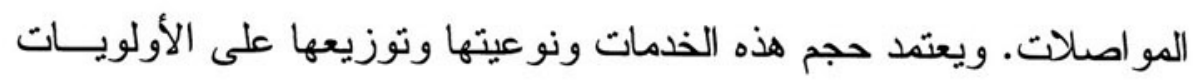

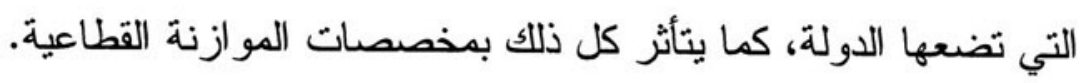

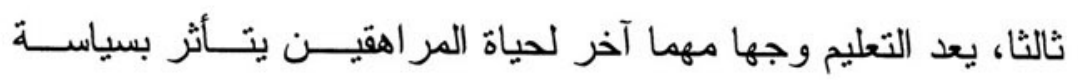

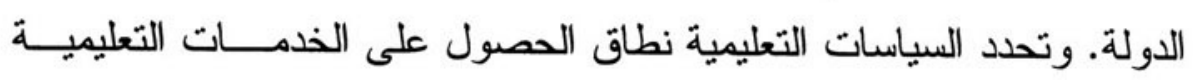

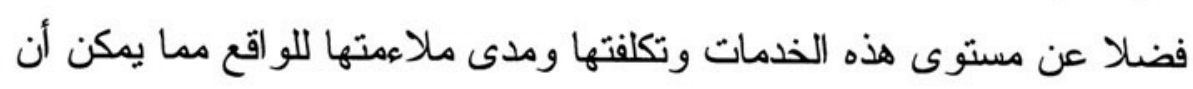

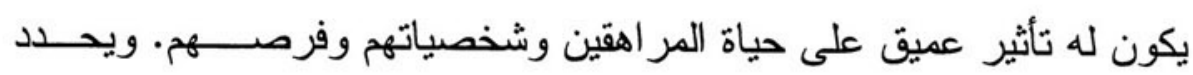

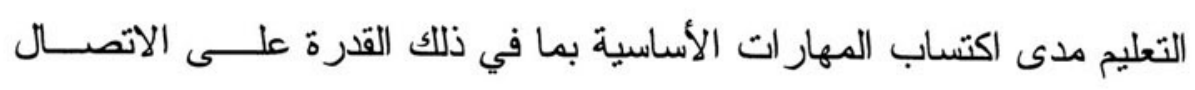
بالآخرين وإجادة الحساب وحل المشكلات و المهار ات البدنية و الاجتماعيــــــة.

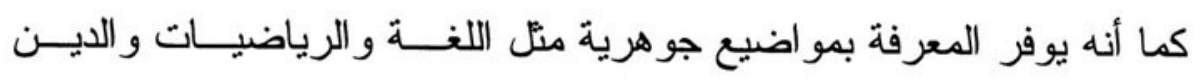

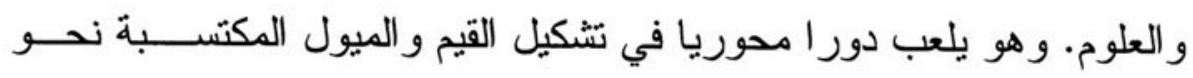


قضايا متل الوطنية و الديمقر اطية و التضامن الاجتماعي و الأدوار المتصلــــــة

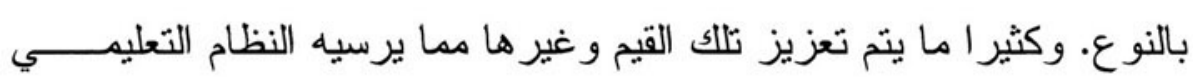

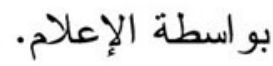

ر ابعا، تحدد سياسة الدولة السلامة البدنية و العقلية للمر اهقيــنـ مـن

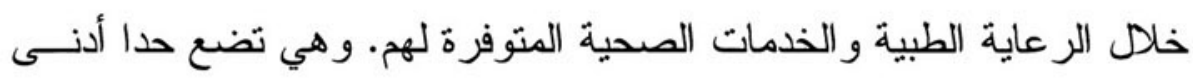

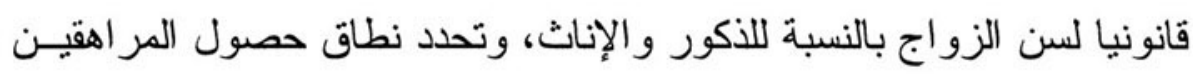

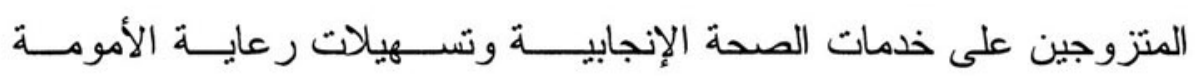

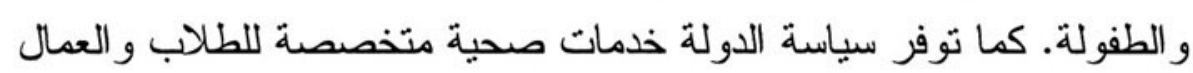
و أصحاب الأمر اض المزمنة.

خامسا، تعد التغذية وجها مهما آخر لحياة المر اهقين ثتأثر بسياســـــة

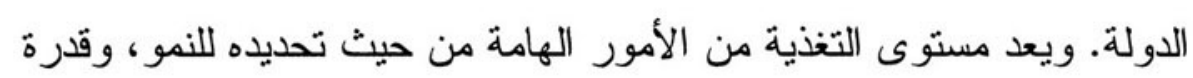

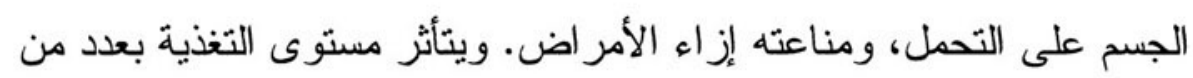
السياسات، بما في ذلك نلك المتعلقة بالزر اعة و التسعير و التجارة. سادسا، تلعب سياسة الدولة دورا في تحديد كيفية شغل وقت فـــــراغ

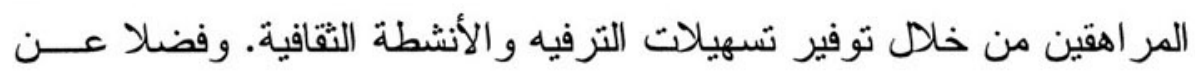

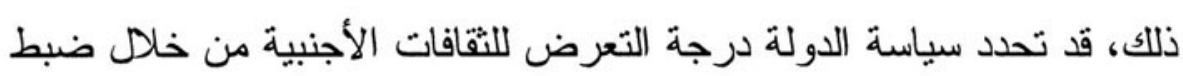

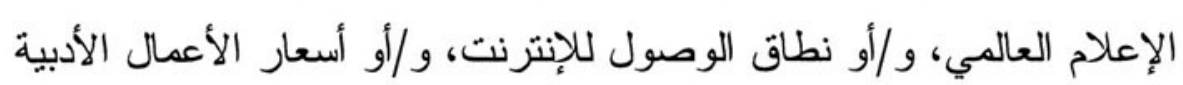

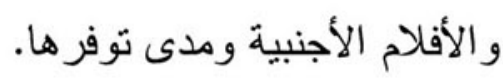

سابعا، تحدد سياسة الدولة نوعية حياة المر اهقين ذوي الاحتياجـــات

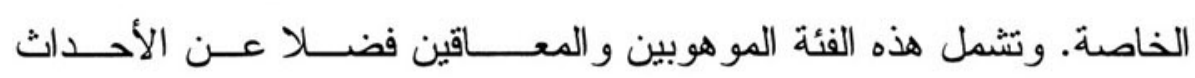

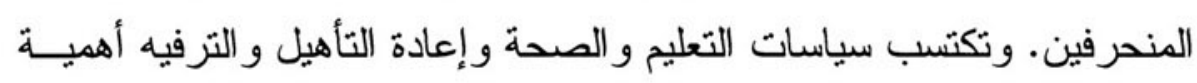

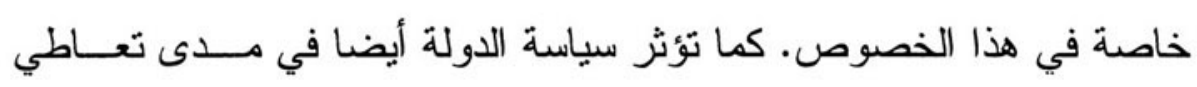


المر اهقين للمخدر ات و النيكوتين من خلال جهود التعليم العام، ومدى ضبـــ أو عدم ضبط التبخ و المخدر ات و المو اد الضارة الأخرى.

ثامنا، تتحكم الدولة في مدى حريـــة التعبـير التــي قـــــيمارســها المر اهقون من خلال الإعلام و اللقاءات العامة. ويتحدد ذلك بو اسطة النظــــام السياسي القائم، ومستوى الديمقر اطية ومدى احتر ام حقوق الإنسان. كما تؤثر

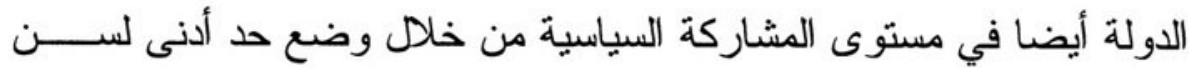
التمتع بالحقوق المدنية وحق التصويت.

في إطار هذه الخلفية، يبرز الفصل القادم النتائج العامة التي توصلنـا

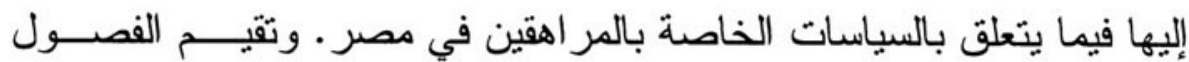

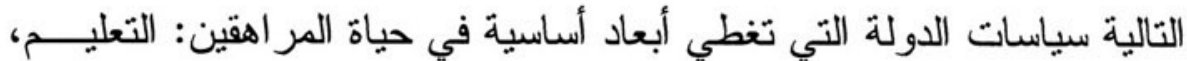

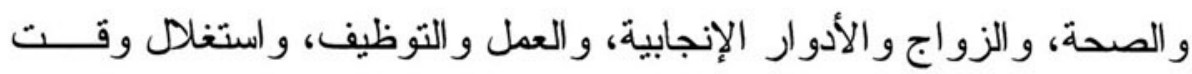

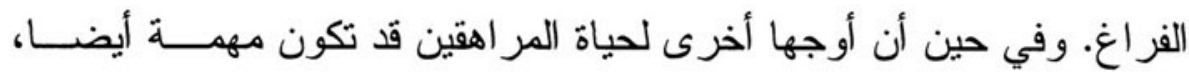

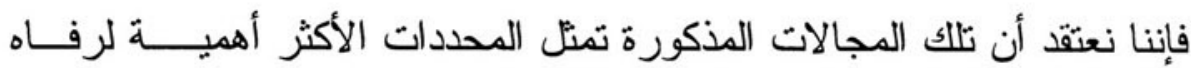
المر اهقين في الحاضر وفرصهم في المستقبل. 


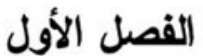

\section{المر اهقة فى السياق المصرى:}

\section{بعض الاستنتاجات العامة}

\section{تعريفات المراهقة}

طلب من المسئولين إعطاء تُعريفاتهم للفترة الزمنيــــة التـــي يكـــون الإنسان فيها بين الطفولة و الكبر ـ وقد ظهرت نتيجتان بارزتان. أو لا، صــار

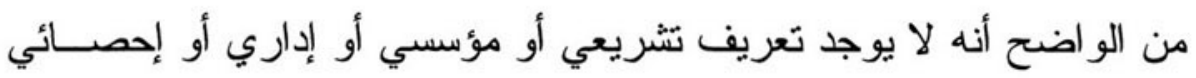

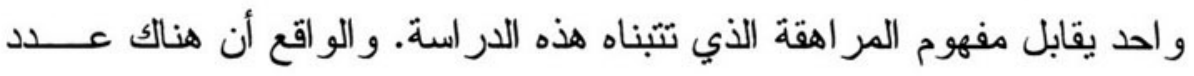
من التعريفات الإجر ائية المستخدمة، كما هو مبين في الجدول أدناه. وثانيــا،

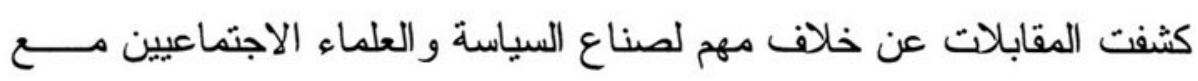

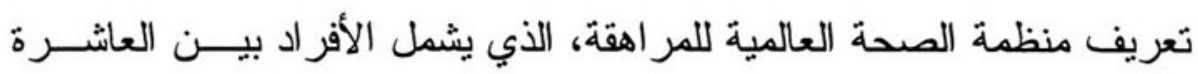

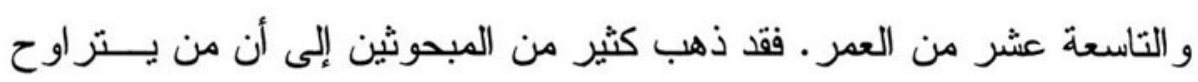

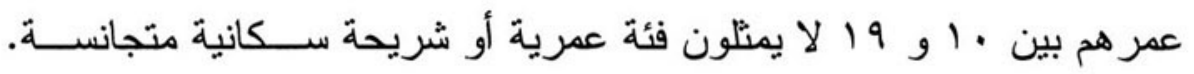

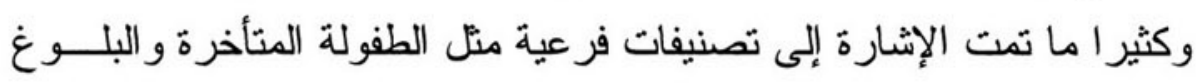

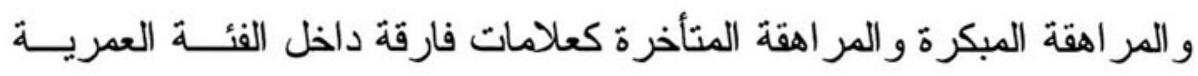

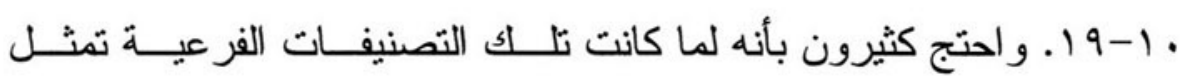

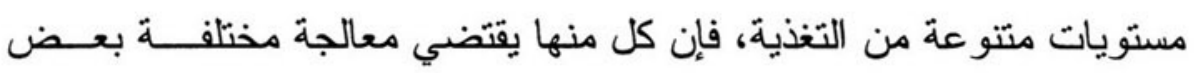

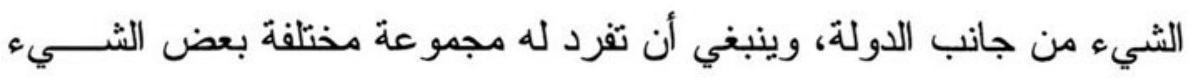

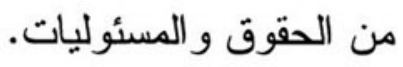

و إذا أمعنا النظر أكثر في الجدول أدناه يتضح لنا بعض الملاحظــات

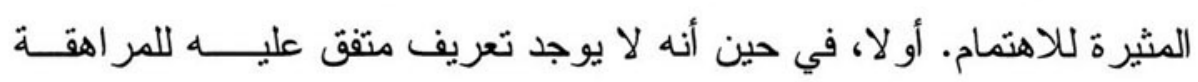
داخل السياق المصري، فإن المصطلح الأكثر شمو لا وقربا في معناه للمر اهقة 
هو فيما يبدو "النشء" الذي يستخدمه الدستور المصري للالالة على فئة تقــع بين الطفولة و الشباب.

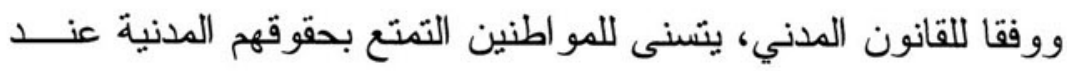

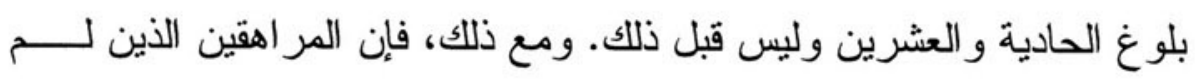

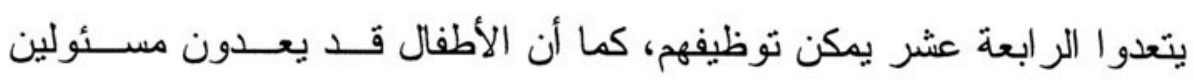

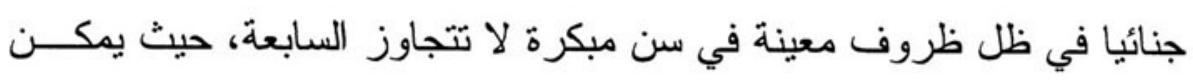

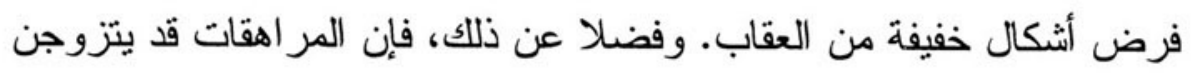

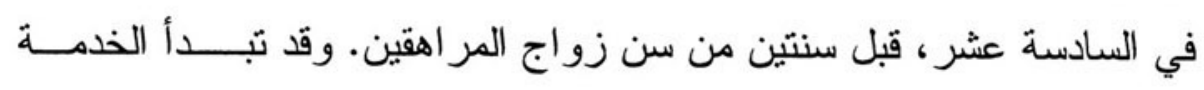

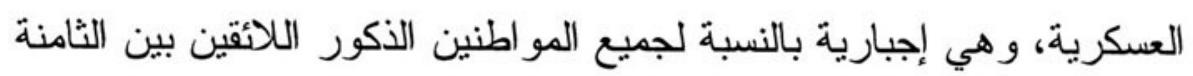

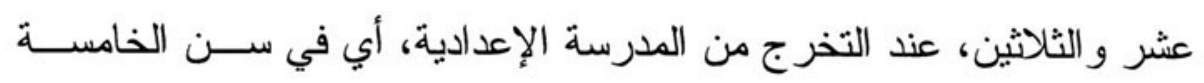
عشر ، وهو سن دخول البنين المدارس الثانوية وحصولهم على التهن التدريب. وفي حين أن هذا التقسيم الظاهري للوظائف الإنسانية وفقا للأعمــال

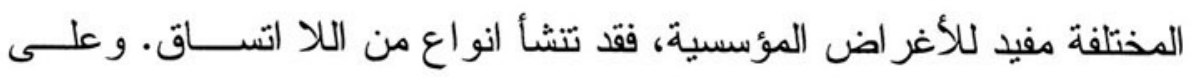
سبيل المثال، يعرف قانون الطفل الذى صدق عليه مجلس الشعب في 1997

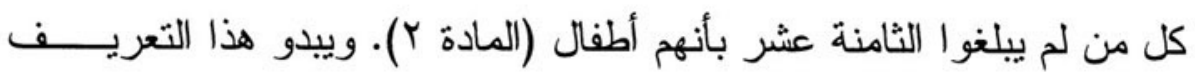

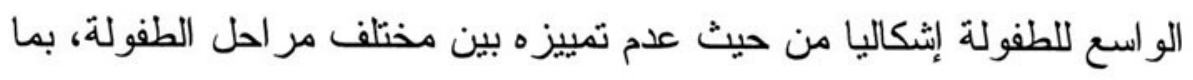

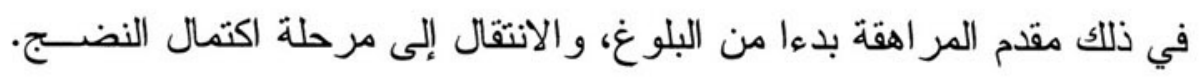

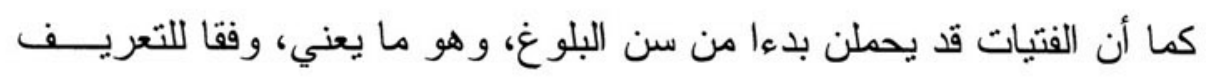

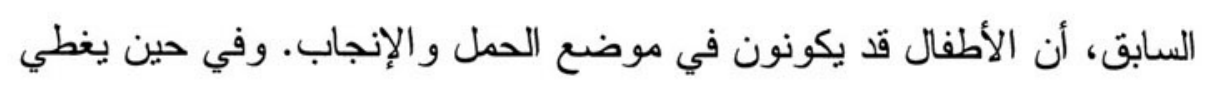

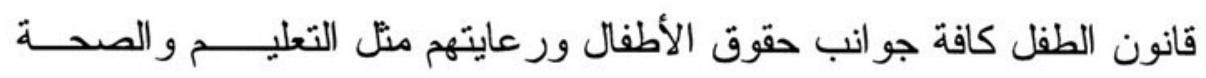

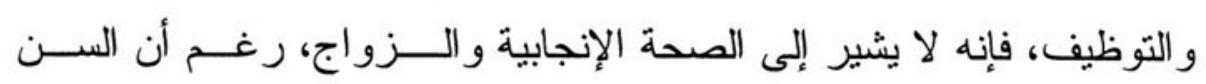

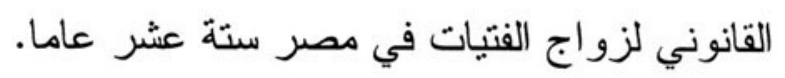




\section{تعريفات المراهقة التي تتبناها الدولة في مصر}

\begin{tabular}{|c|c|c|}
\hline تعريفات/مصطلحات & الفئات العمرية & الهيئات الحكومية \\
\hline 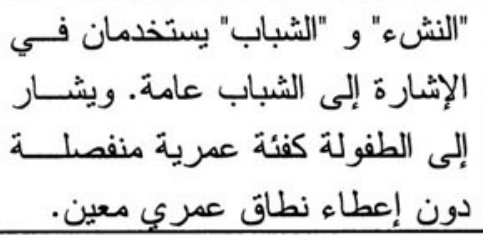 & غير محدد & 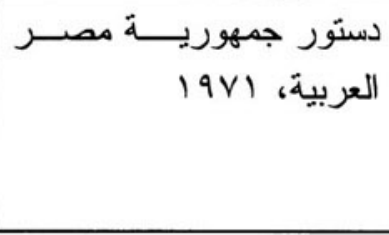 \\
\hline 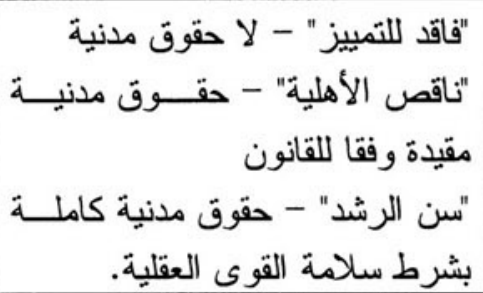 & 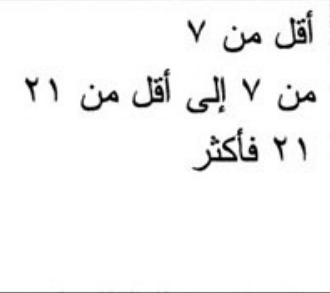 & القانون المدني رقم 190 لعام \\
\hline 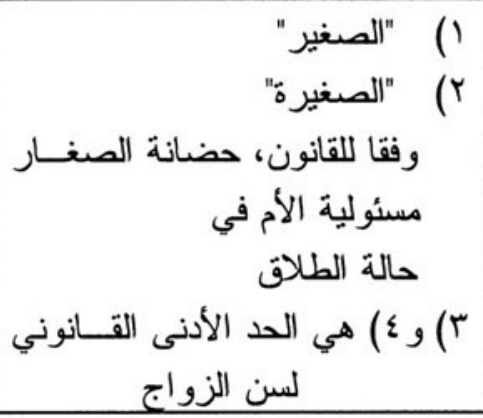 & 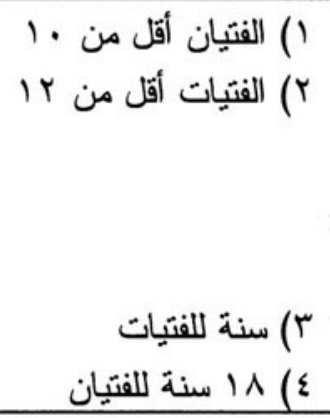 & قانون الأحو ال الشخصية \\
\hline 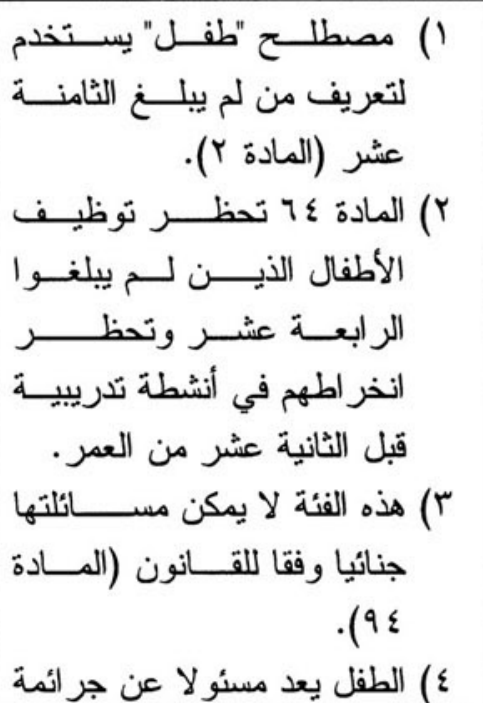 & ع) من V إلى 10 & 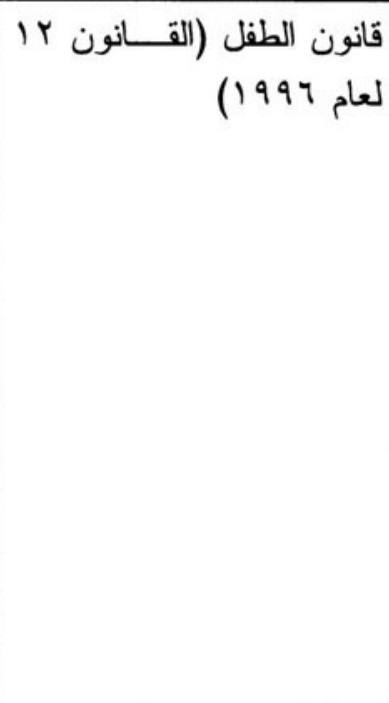 \\
\hline
\end{tabular}




\begin{tabular}{|c|c|c|}
\hline 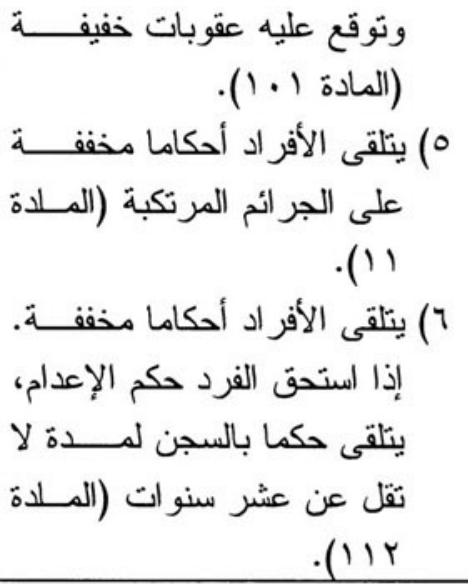 & 0) من 10 إلى 17 & \\
\hline 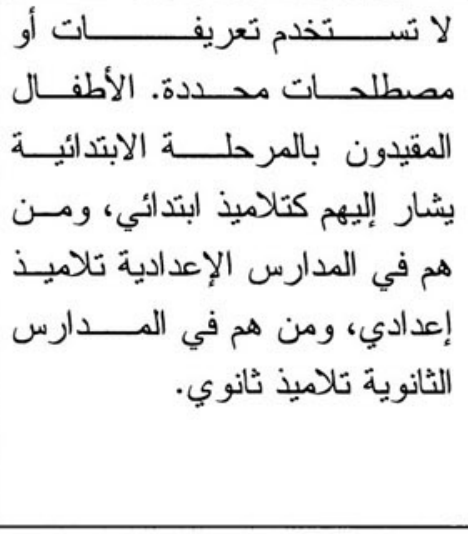 & 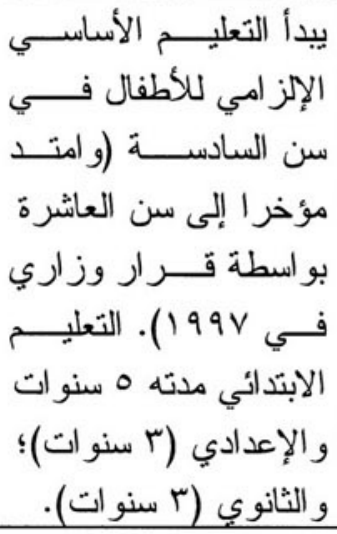 & 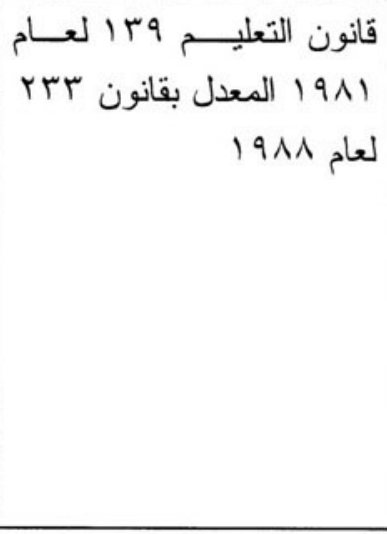 \\
\hline 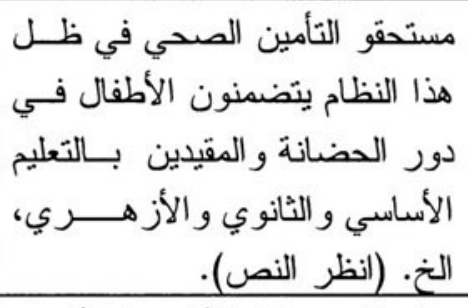 & غير محدد & 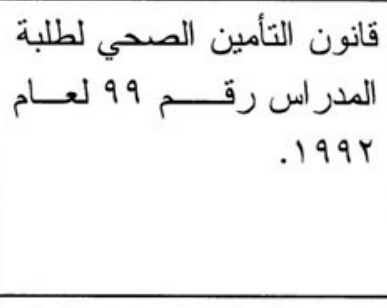 \\
\hline 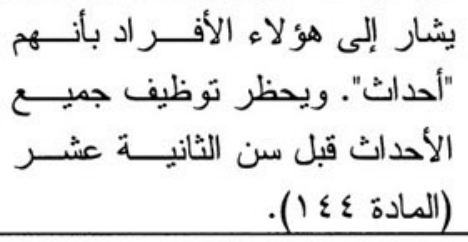 & $1 V-1 Y$ & 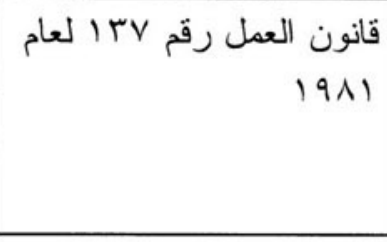 \\
\hline "الطلائع" & $1 \wedge-7$ & والرجلس الأعلـــى للشــباب \\
\hline 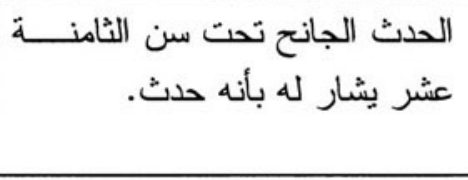 & 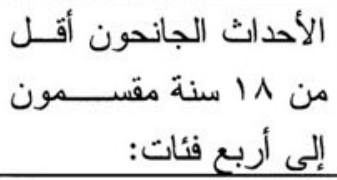 & 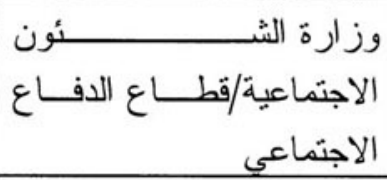 \\
\hline
\end{tabular}




\begin{tabular}{|c|c|c|}
\hline 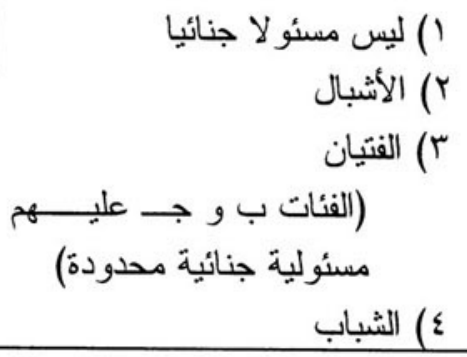 & 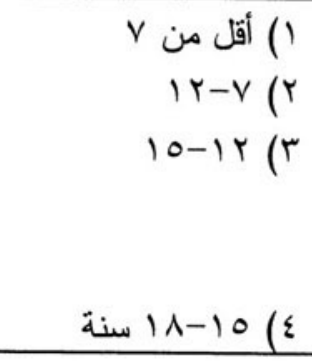 & \\
\hline 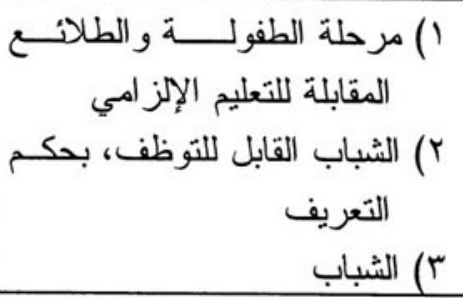 & 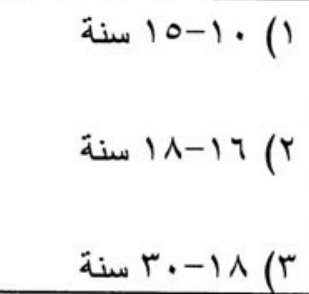 & 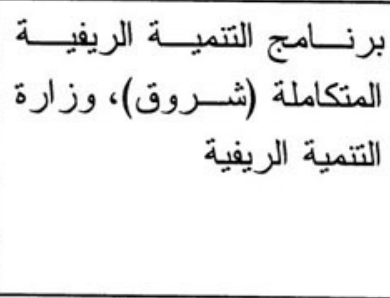 \\
\hline 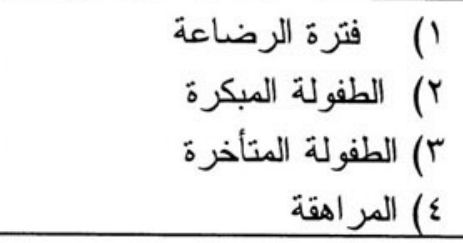 & 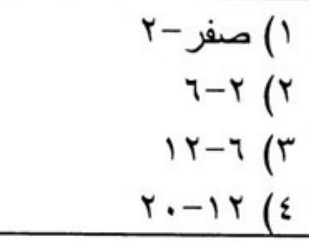 & 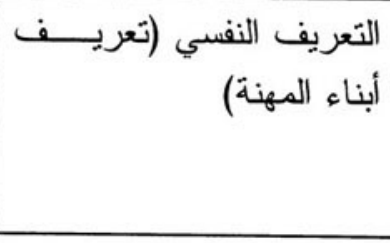 \\
\hline 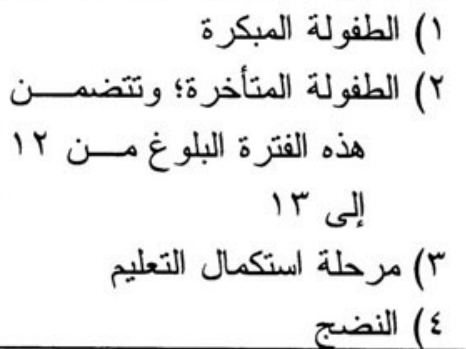 & 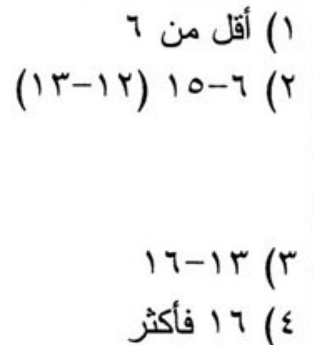 & 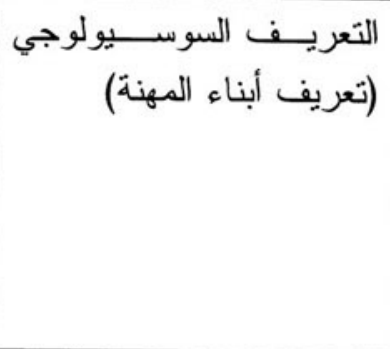 \\
\hline
\end{tabular}

ليس لمصطلح المر اهقة حدود فاصلة و اضحة فــي أذهـــان صنـــاع

السياسة. وقد تؤدي تلك التعريفات المتعددة للارنباك و افتقاد التجانس. وفضلا

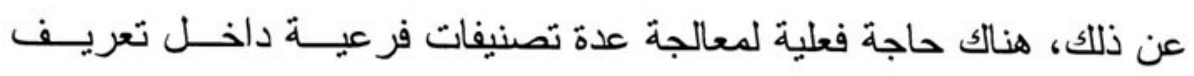
منظمة الصحة العالمية. وسنتتاول استتباعات هذه النقاط في أقسام تالية مــن الثقرير 


\section{وصف المراهقة}

كشفت المقابلات عن درجة عالية من الاتفاق بشأن أبــرز الســمات المميزة للمر اهقين. وقد تم تعريف المر اهقة بأنها فترة نضوج حرجة وجسـر بين الطفولة و الكبر ـ كما تم إير از التغير ات النفسية و الفســـيولوجية المهمـــة.

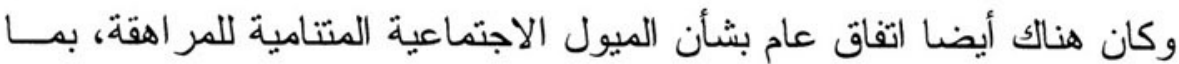
في ذلك الميل المتز ايد نحو تأكيد الذات و الاســتقلال و التفــاعل الاجتمـــاعي خار ج دائرة الأسرة، وخاصة مـــع الأصدقــاء و الأقــر ان. وو افـق أغلــب

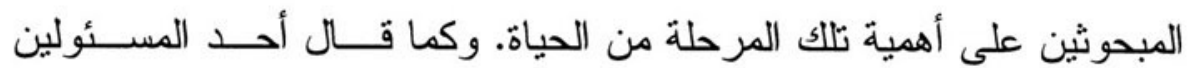

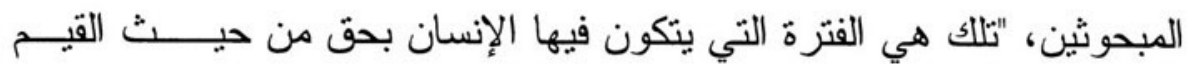
و الشخصية و المعرفة و الموقف من الحياة".

الإطار المؤسسي للمر اهقة في مصر لا توجد هيئة أو وزارة واحدة بالدولة تتعامل مع المر اهقين. وبالمثل، ليس هناك بيان موحد عن السياسة. وتثتوزع صلاحية التعامل مع المر اهقيـن على عدد من الكيانات تتعامل كل منها مع بعد واحد أو أكثر . على المسـتوى التتفيذي، تتضمن هذه الكيانات وز ار ات التعليم، و التعليم العـــالي، و الصحـــة و السكان، و الشئون الاجتماعية، و الدفاع، و الداخلية، و الإعلام، و القوى العاملة و الهجرة، و الثقافة، و العدل، و المجلس الأعلى للشباب و الرياضة، و المجلـــس القومي للأمومة و الطفولة، فضلا عن المحافظات على المســـــى المحلــي. و على المستوى التشريعي، تز اجع لجنة متخصصة للشباب داخــــلـ مجلــس الشعب جميع المقترحات المنعلقة بالمر اهقين و الشباب. 


\section{احتياجات المر اهقين ومشاكلهم و التحديات التى تو اجههم}

تراوحت الردود بشكل كبير فيما يتعلق باحتياجات ومشاكل المر اهقين

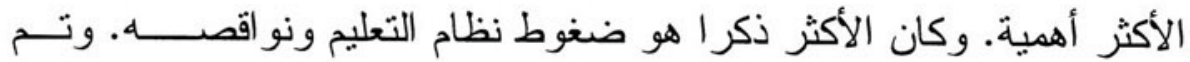

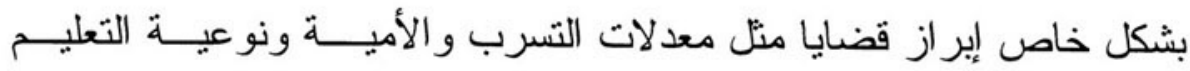

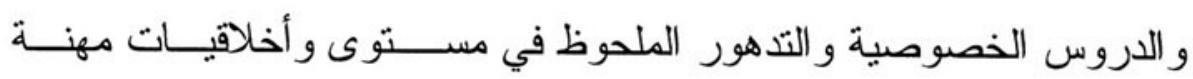

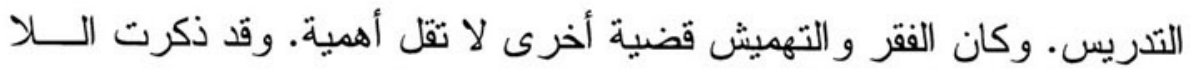

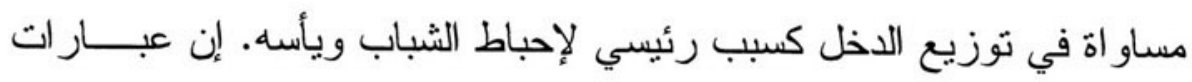

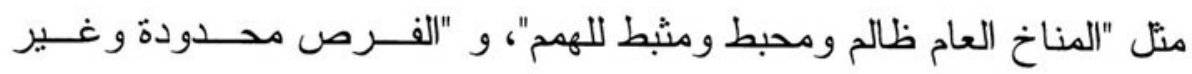

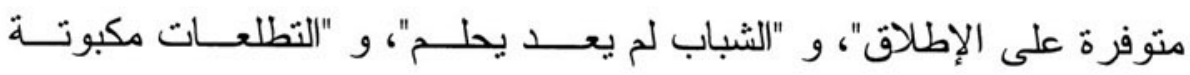

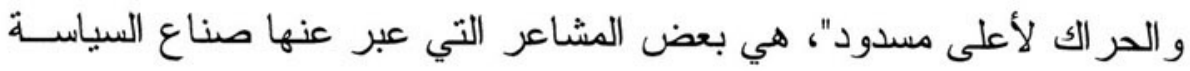

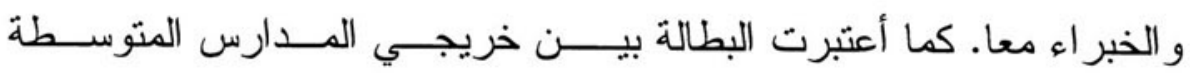

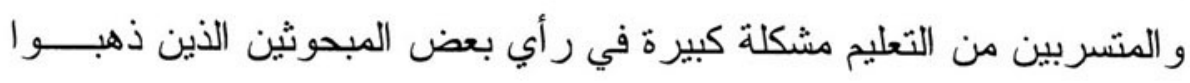

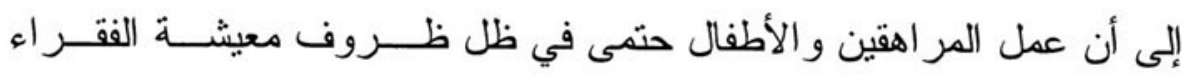

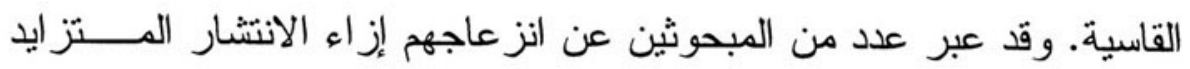

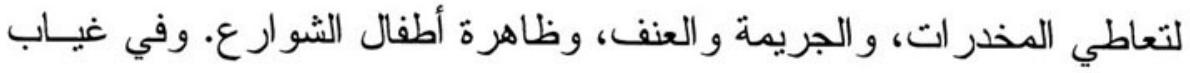

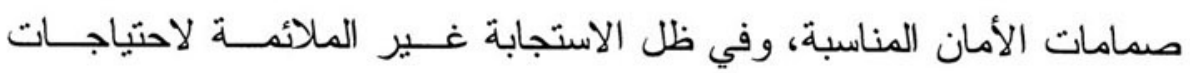

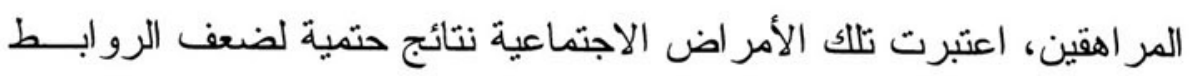

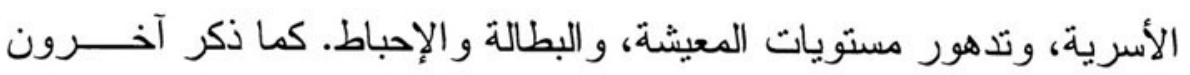
قابلية الشباب للإنضمام الى الحركات الدينية المنطرفة.

وفي ظل القلق بشأن زو اج المر اهقين في أوساط العاملين في مجــال

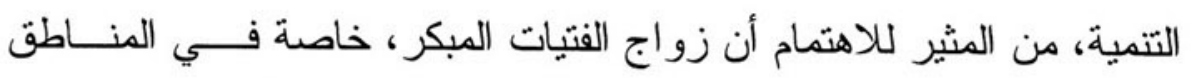

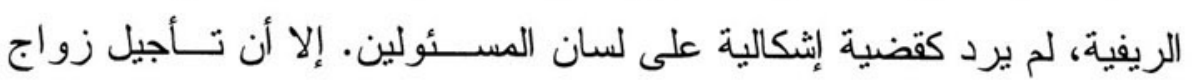

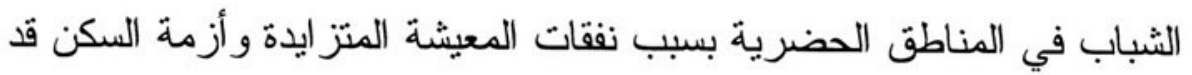




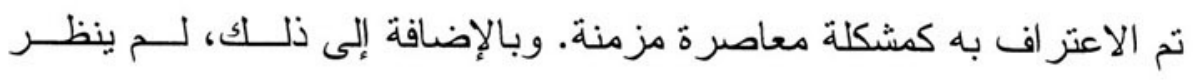
للمشكلات الصحية وختان الإناث كقضايا إثكالية سوى من جانب العـــاملين

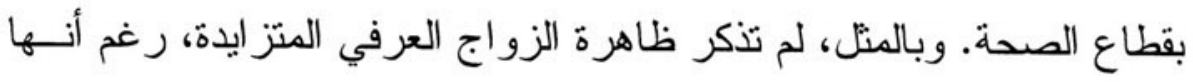

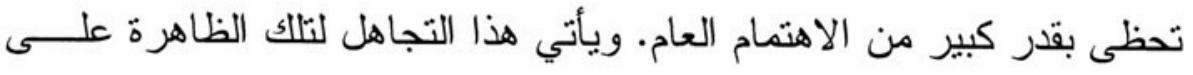

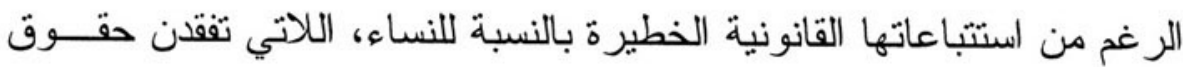
كثيرة في حالة الطلاق أو وفاة الزوج.

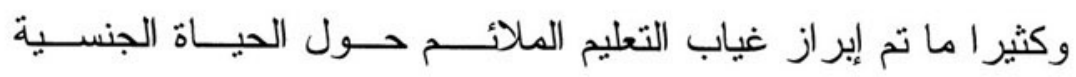

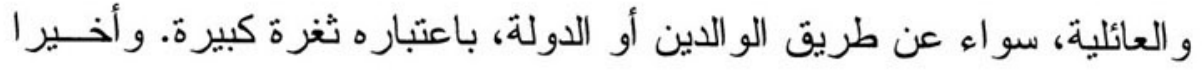

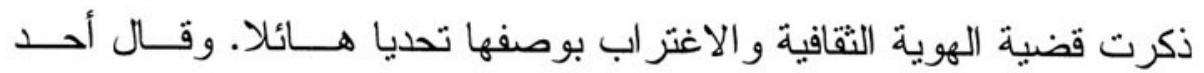

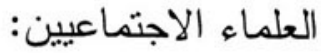
"معضلة التمسك بالتعاليم و القيم الدينية في مو اجهة الامتثــــال

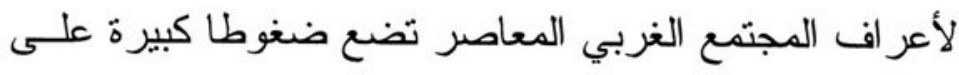

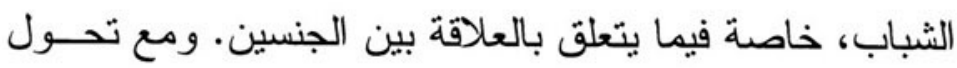

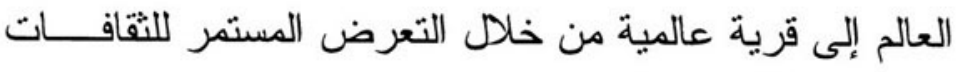
و المتل الأجنبية عن طريق وسائل الإعلام و أطباق الاســـنقبال و الإنترنت، يجد الثباب نفسه بدون إدر الك منه بين شقي رحى الإنى

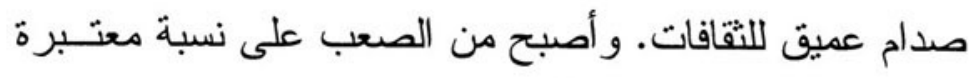

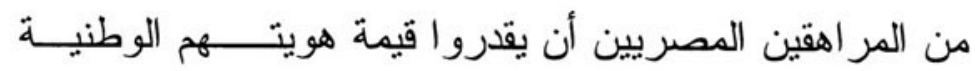
وتقاليدهم وتر اثهم الثقافي الثري".

دور الدولة في معالجة احتياجات ومشاكل المراهقين

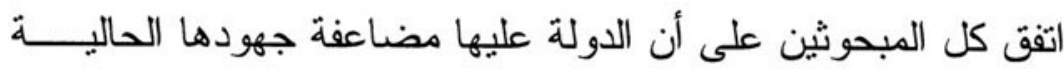
لحل المشكلات الأكثر إلحاحا التي تو اجه المر اهقين اليوم. وكان هناك شعاك شعور

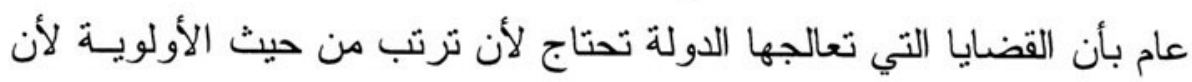


الجهود كثير ا ما تتصرف بعيدا عن معالجة القضايا الهيكلية طويلـــة الهـدى لصالح معالجة المشكلات قصيرة المدى. وبالمقارنة بالفئات العمرية الأخرى (متل الطفولة المبكرة و الكـــبر)،

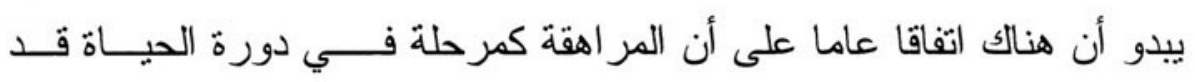

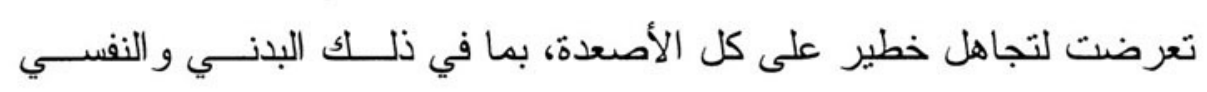

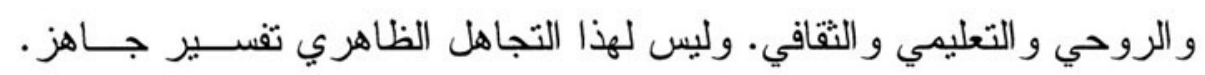

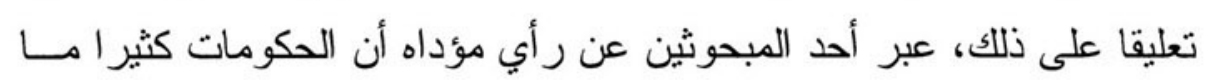

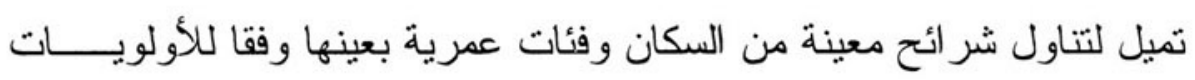

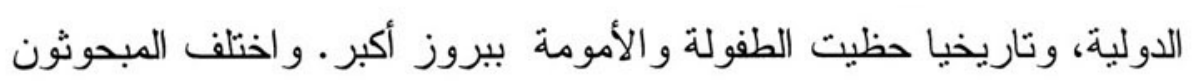

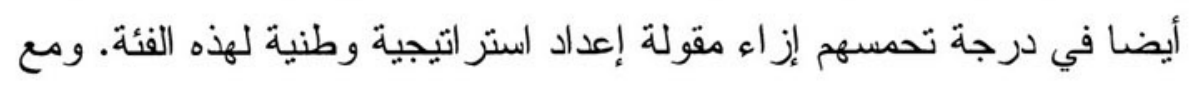
ذلك، فقد كان هناك اتفاق عام على الحاجة لعمل سريع وأن هذه الفئة العمرية ينبغي أن تحتل مكانة أعلى على جدول أعمال الدولة. ومن بين المشاعر العامة المشتركة بين المبحوثين أن هنــالك فجــوة ظاهرة بين العلاقة النظرية بين الدولة و المر اهقين من جانب، و علاقتهم فــي لئي

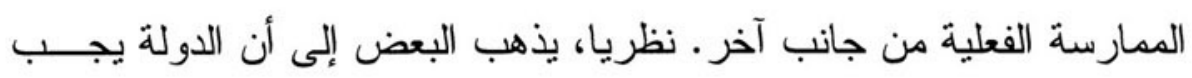

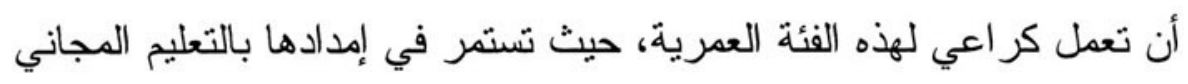

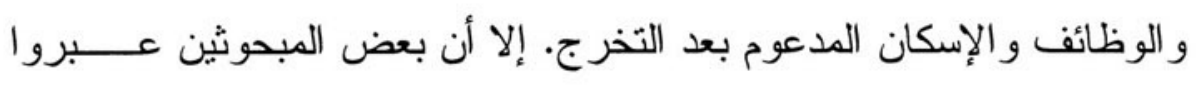

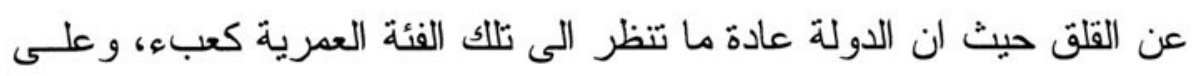

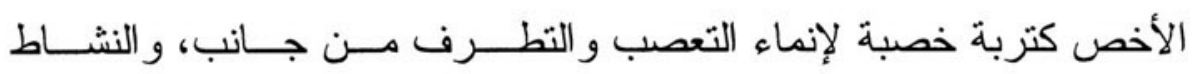

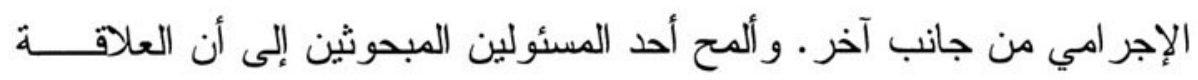

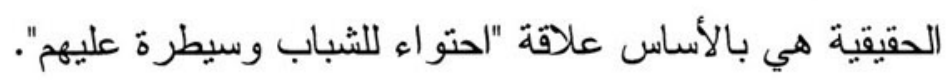


مجموعات المراهقين ذوى الأوضاع الخاصة والمهملين

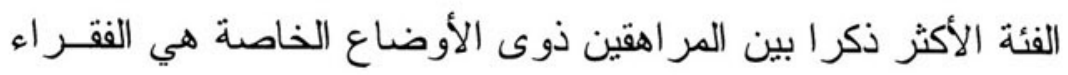

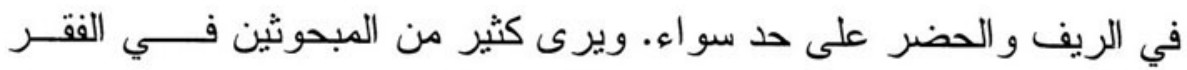

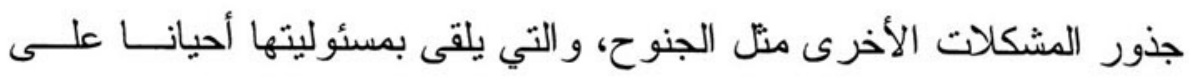
الأسرة أو الشباب نفسه. كما ذكرت أيضا المر اهقات وكذللك المعاقين بدنيـــا. إلا أن المعاقين ذهنيا لم يذكروا بو اسطة أي من المبحوثين.

\section{المسئولية الجماعية عن المراهقين}

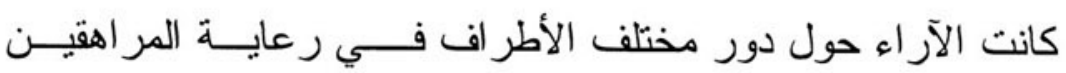

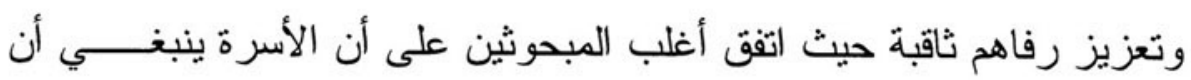

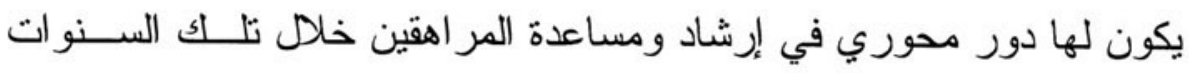

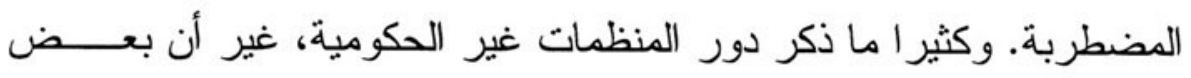

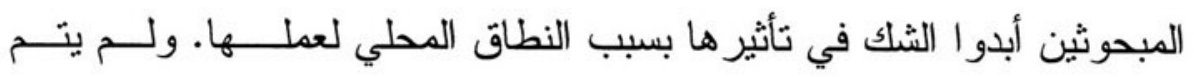

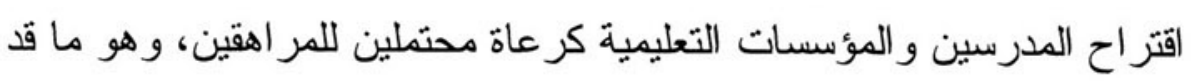

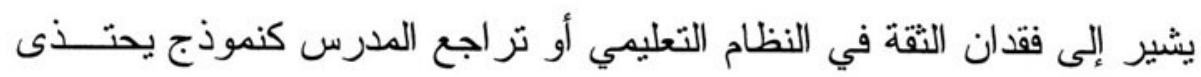

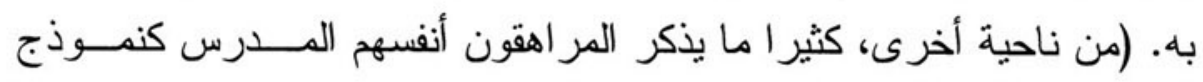

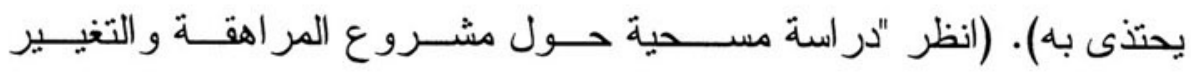

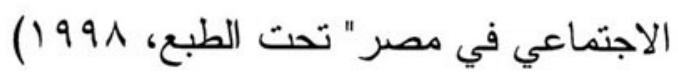




\section{الفصل الثاني: التعليم}

$$
\text { "التعليم كالماء و الهو اء حق للجميع." طه حسين لفئني: }
$$

\section{مقدمة}

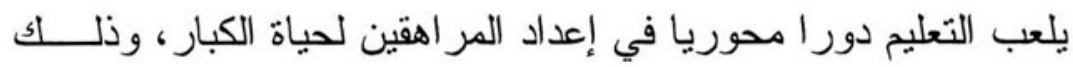

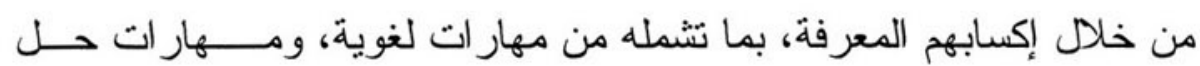
المشاكل و المهار ات الرياضية ومهار ات التعامل مع الآخرين وكثير غير هـانـا.

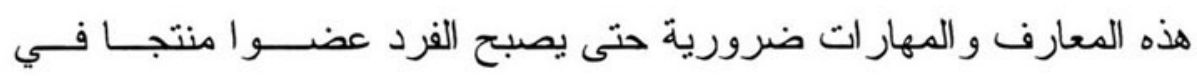

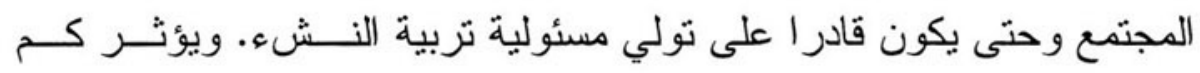

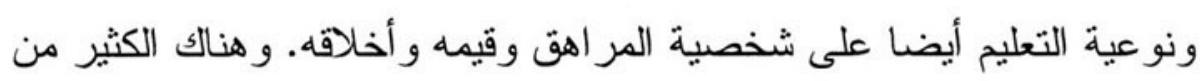

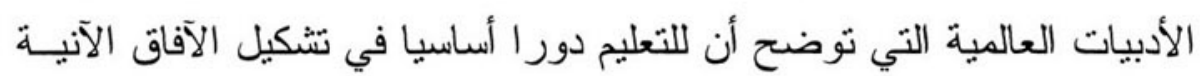

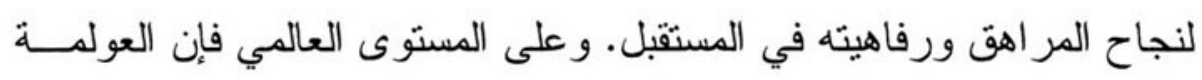

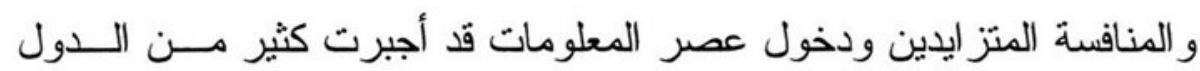
على مر اجعة وتطوير وتحديث نظمها التعليمية. و التعليم قطاع أساسي في مصر، بلغ الإنفاق العام عليه r, \% ؛ كنسبة

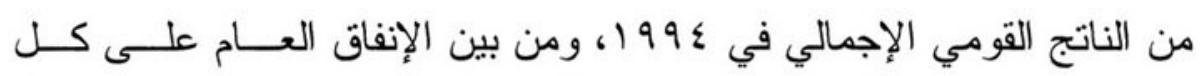

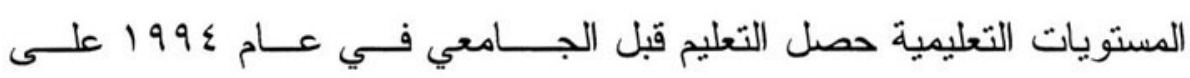

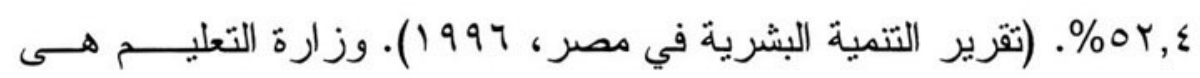

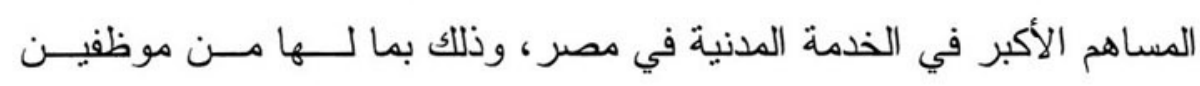

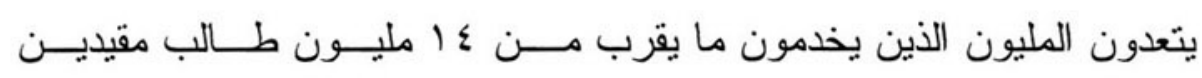

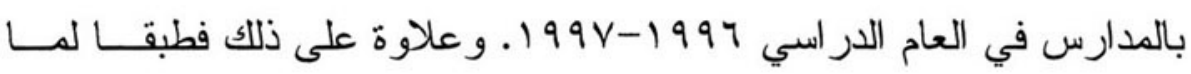

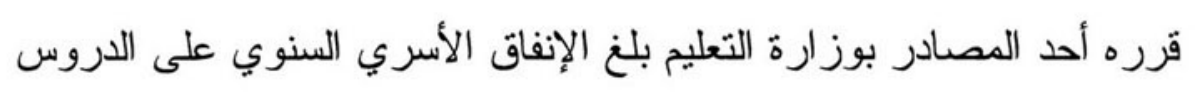


الخصوصية لتلاميذ المدارس الحكومية V بليون جنيه في عام Y99 ا ـ ـويقدر

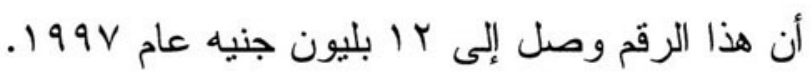

لقد شهد العقد الحالي التزام سياسي هائل بتحسين التعليم بإعتباره احد

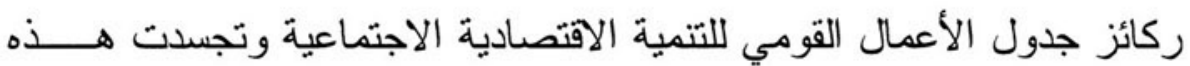
الإر ادة السياسية في إعلان الرئيس مبارك التعليم مشرو عا قوميا للتسـعينات.

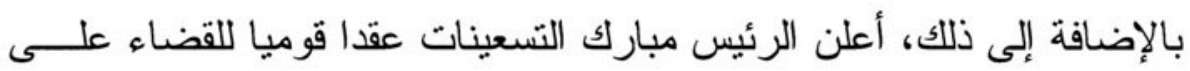

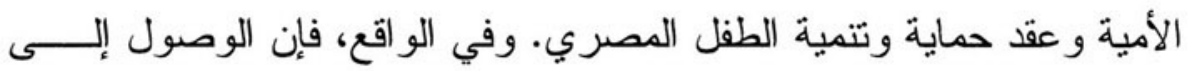

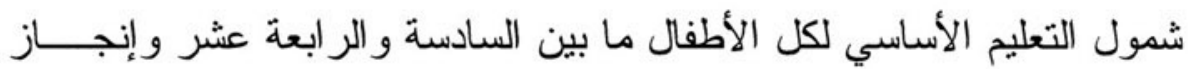

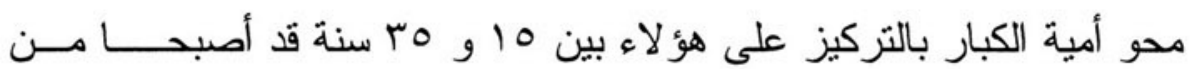
قضايا الأمن القومي في مصر ـ كما كان للتصديق على اتفاقية حقوق الطفــلــل

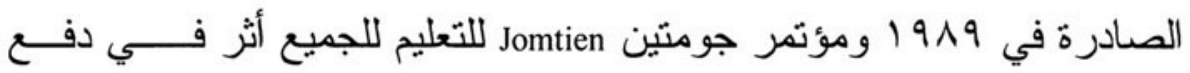

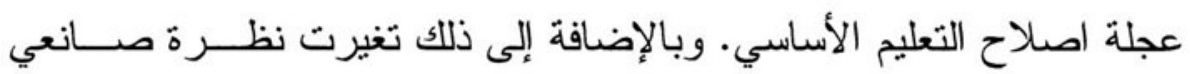
السياسات إلى التعليم كنتيجة لتقدم الإصلاحات الاقتصادية، فأصبح ينظر إليه

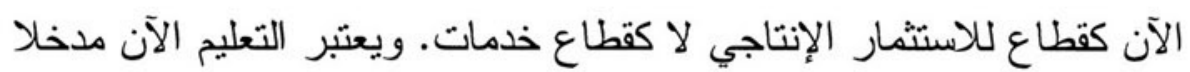

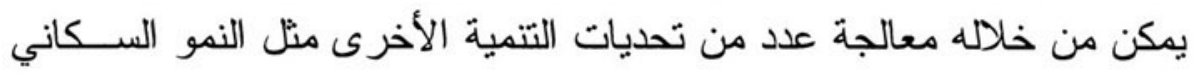
و الصحة ومسائل البيئة و الفقر.

ومن أجل تجديد قوى التعليم الأساسي وتحديثه في مصـــر بــادرت وز ارة التعليم بجهد إصلاحي شامل في 1991 لمعالجة عدد من التحديـــــات

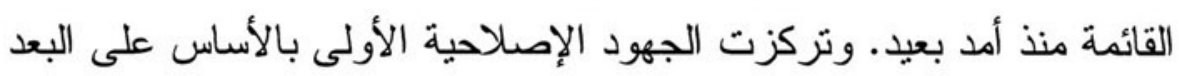

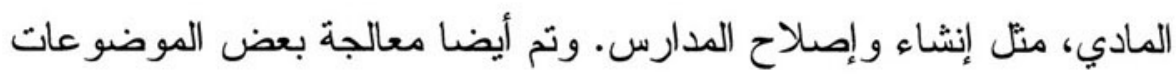

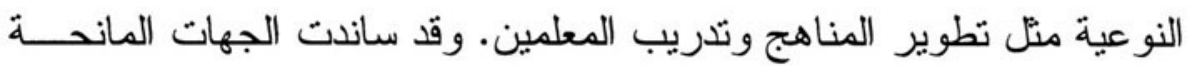
و المنظمات غير الحكومية الدولية أولويات وزارة التعليم. 
بالر غم من وجود قوة الدفع من أجل مزيد من الإصلاحات، لم يكــنـ

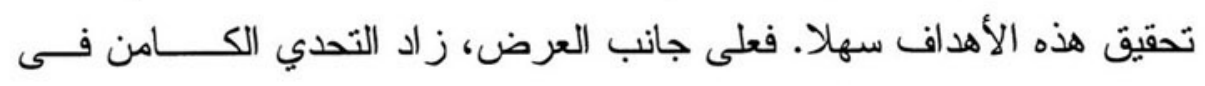

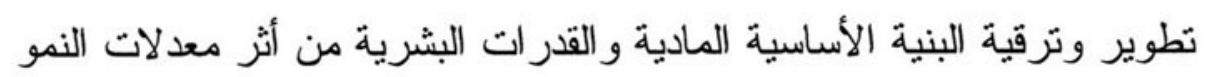

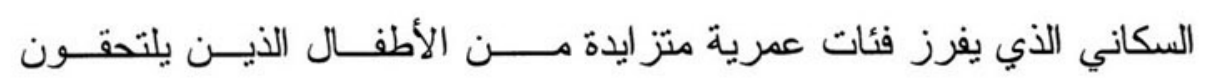

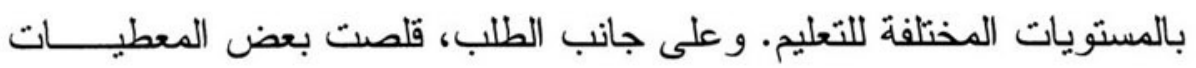

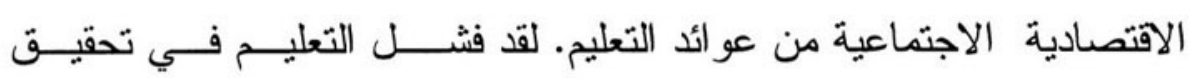
تحسينات بعثد بها في الدخل وشروط المعيشة والمركز الاجتماعي لقسم كبير

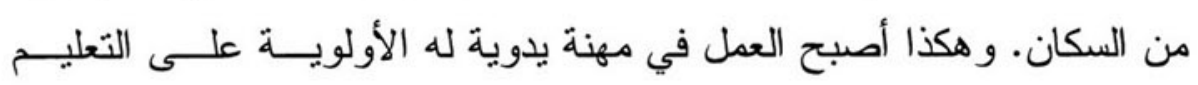

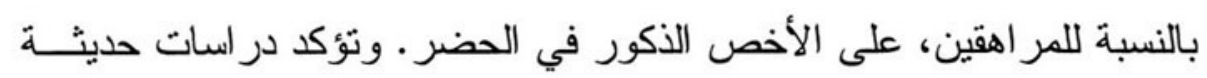

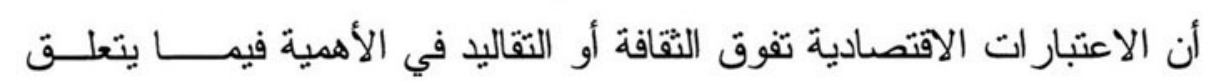

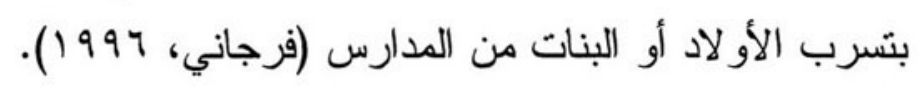

لأغر اض هذا الفصل يشمل تعليم المر اهقين في الفئة العمرية من . 1.

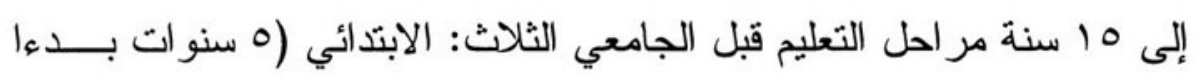

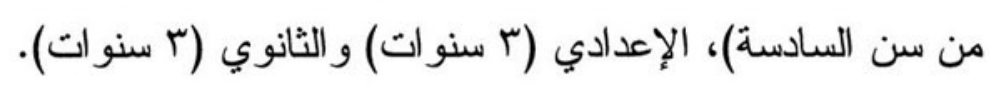

تشريعات التعليم الحالية ونظام التعليم يقوم النظام التعليمي المصري على الأسس التي ينص عليها الدسنور

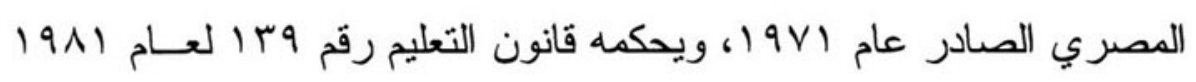

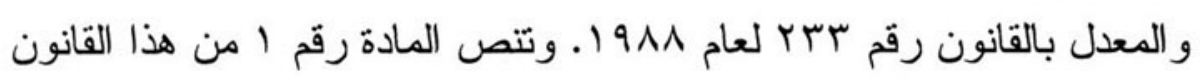

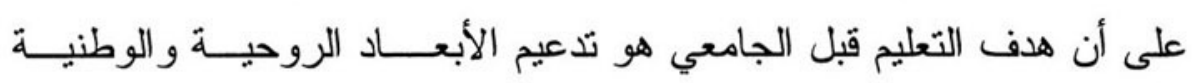

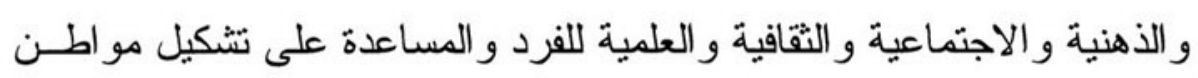

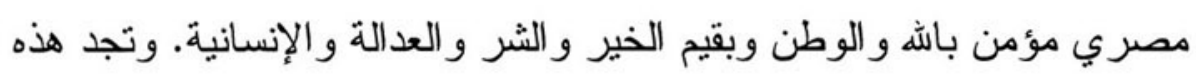

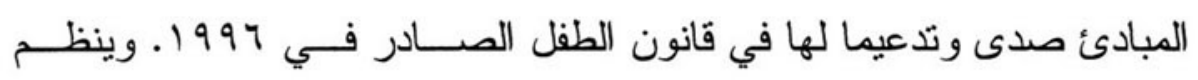


القانون في مو اد أخرى سياسات وممارسات المدارس. و هناك ثلاثثة مبــــادئ أساسية تحكم الهيكل و التنظيم الحاليين لنظام التعليم.

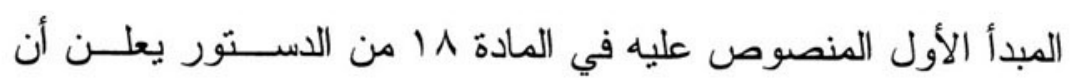

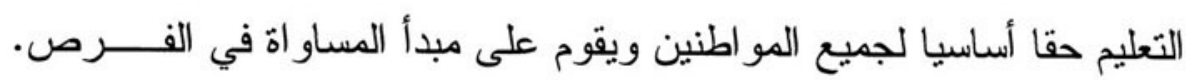

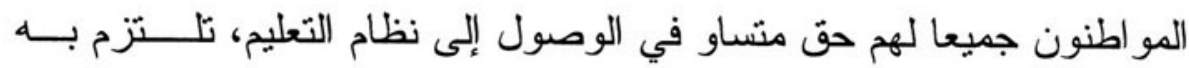

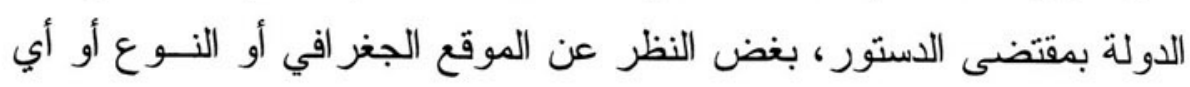

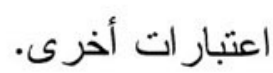

المبدأ الثاني، كما تتص عليه المادة • r من الدستور و المادة ب مـــن

قانون التعليم، يلزم الدولة بتوفير التعليم (بمستوييه الجامعي وقبل الجــامعي)

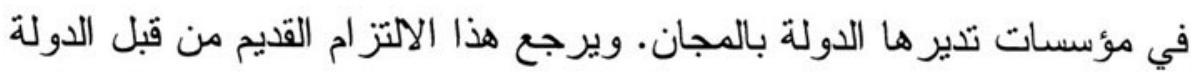

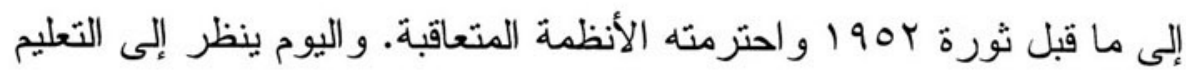

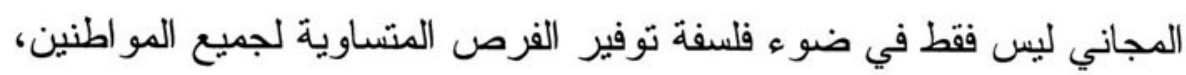

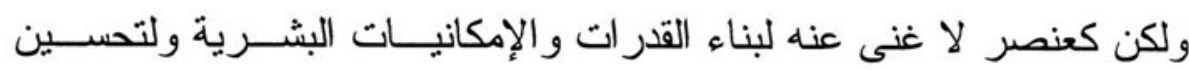
مستوى المعيشة وبناء أمة حديثة قوية.

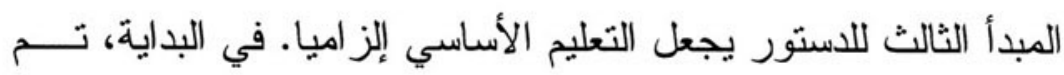

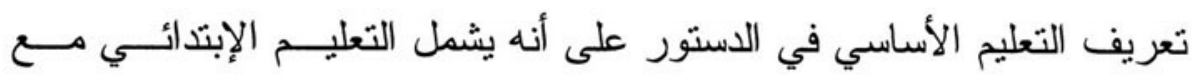

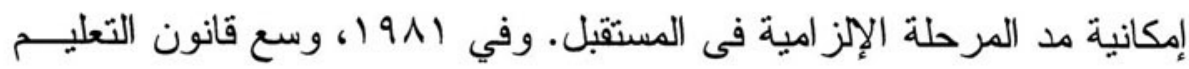

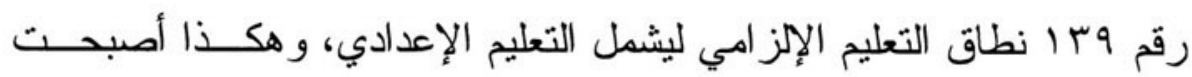

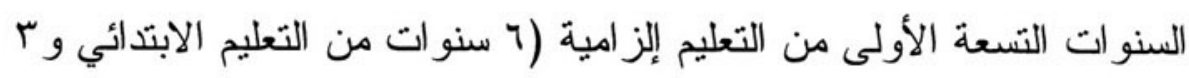

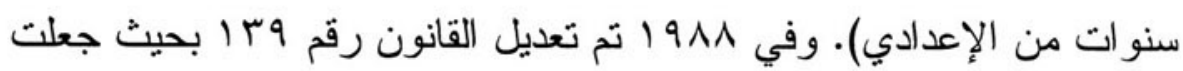

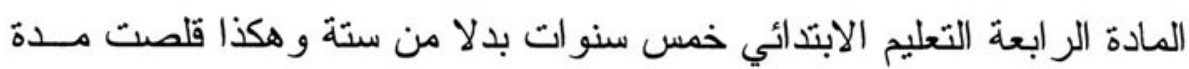
التعليم الإلز امي سنة واحدة. 
وتقضى المادة 10 من القانون المعدل بأن التعليم الأساسي حق لكـلـ

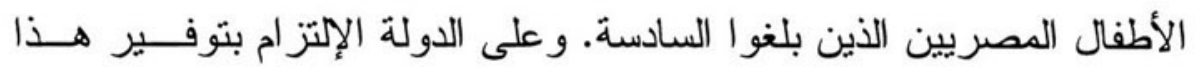

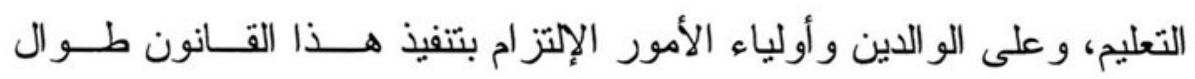

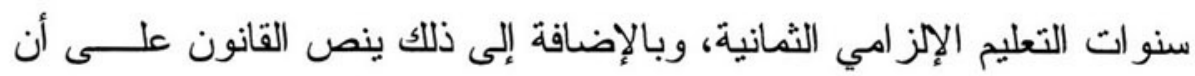

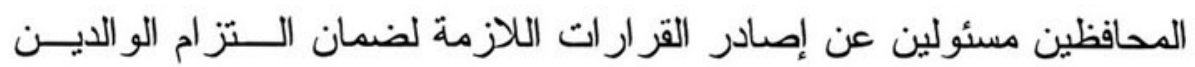

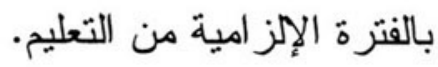

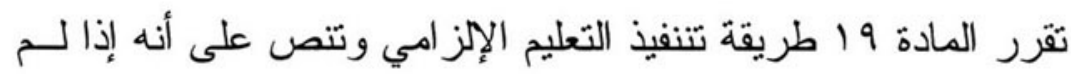

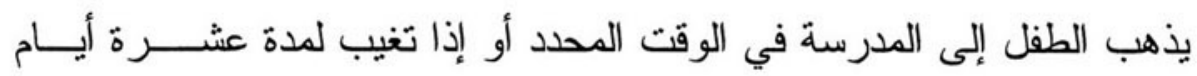
منصلين أو متفرقين بدون عذر مقبول، يجب على ناظر المدرسة أن يخطــر

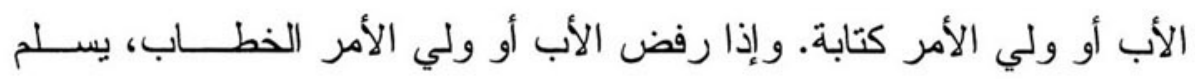

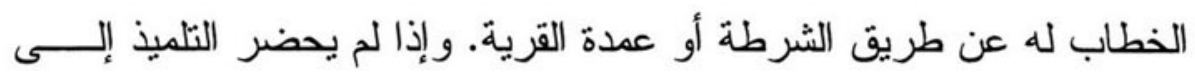

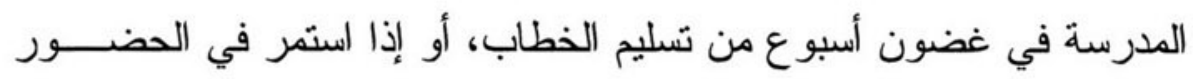

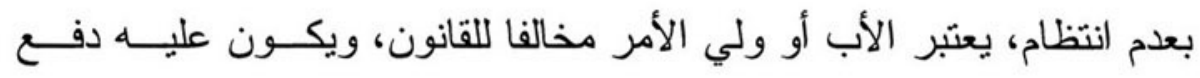

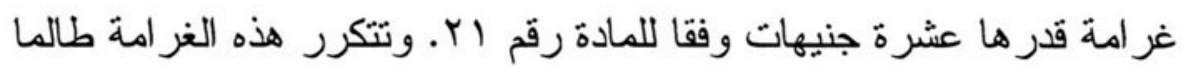
استمر غياب الطفل دون عذر مقبول بعد إخطار الأب أو ولي الأمر.

وتدعم المادة رقم عه من قانون الطفل هذا المبدأ ناصــــة علــى أن

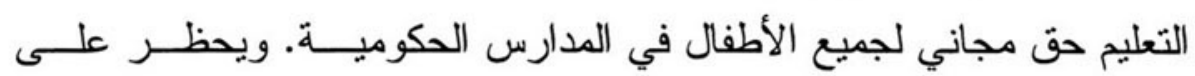

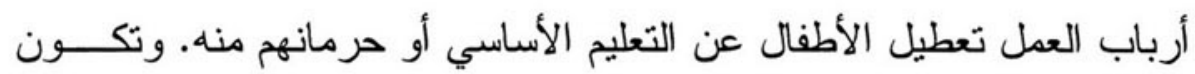

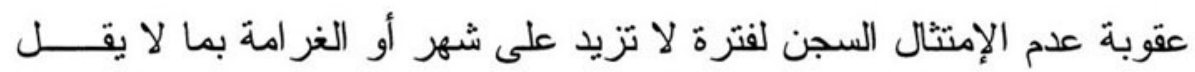
عن مائتي جنيه و لا يزيد عن . .0 جنيه. 


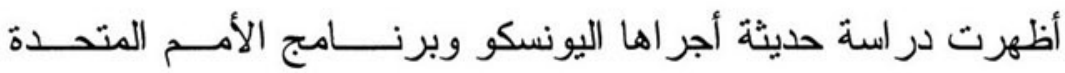
الإنمائي حول إصلاحات التعليم الأساسي في مصر أن النصــف الأول مــن التسعينات شهد زيادات ملحوظة في القيد في التعليم الأساسي، من حو الي 11

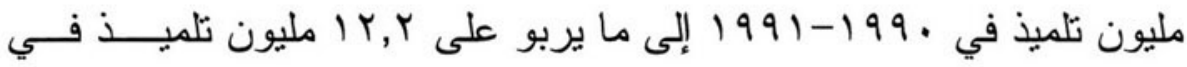

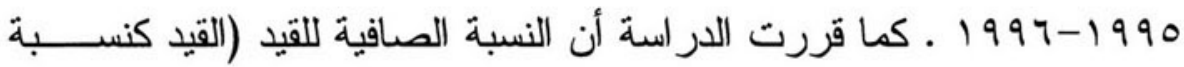
إلى السكان في سن التعليم) كان ثابتا عند مستوى 10 في المائة (اليونســـكو وبرنامج الأمم المتحدة الإنمائي، 997 (1). ويمضى مشروع الحكومة الطموح لبناء مدارس جديدة و إصلاح المبانى القديمة قدما، لإستيعاب العدد المــــز ايد من السكان في سن التعليم ولخدمة الأماكن المحرومة.

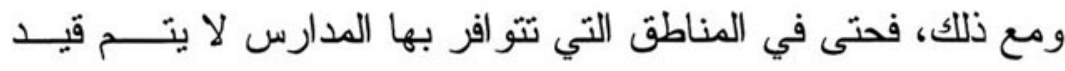
بعض الأطفال. وتكثف بعض الإحصائيات الحديثة عن تفاوت بين النشـريع و الممارسة. إن فرض التعليم الأساسي الإلزامي غير عملي ومكلف في نفس الوقت. في المناطق التي ينخفض فيها القيد يمكن أن تـــأتي حمـلات نشــر الوعي في القرية المصحوبة بنشاطات تعويضية مدرة للاخل للعائلات الفقيرة

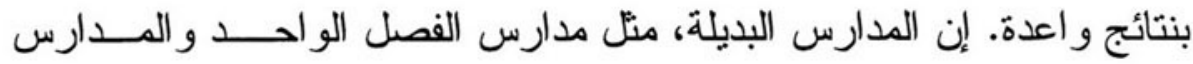
الأهلية، تثبت نجاحها كوسيلة لقيد أعداد أكبر من الفتيات في المناطق الريفية المنعزلة. و أيضا هناك جهود حالية لخلق حو افز للأبــــاء لتســـيل الأطفــال

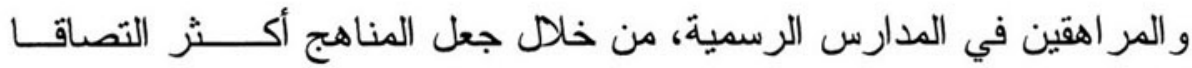
بحاجات المجتمع و أكثر مرونة بحيث تسمح بنشاطات إنتاجية أخرى. كل هذه العو امل يجب أخذها في الاعتبار قبل إدماج التعليم الثانوي كجزء من التعليـم 
الأساسي الإلز امي، و هو الهذف الذى تسعى الى تحقيقـــهـ الخطـــة الخمســية الحالية.

الاستمرار في التعليم

تعد مشكلة الاستمر ار في التعليم تحديا هاما لا يقل أهمية عن مســألة

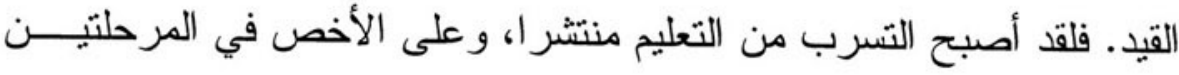

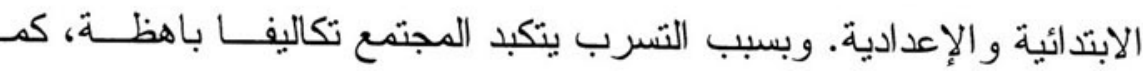

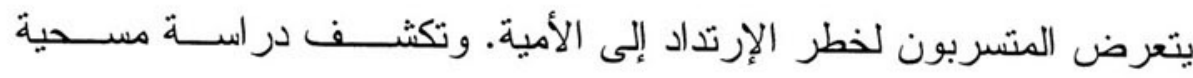

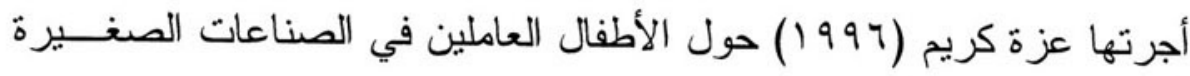
في الحضر عن أن أهم أسباب التسرب من التعليم تشمل الخـــبرات الســلبية التي يلقاها الطالب في نظام التعليم، مثل الرسوب المتكرر و وإساءة المدرسـين

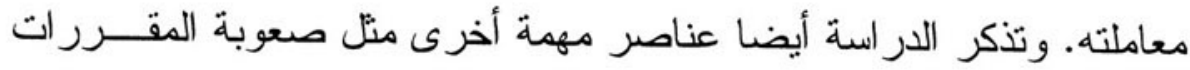

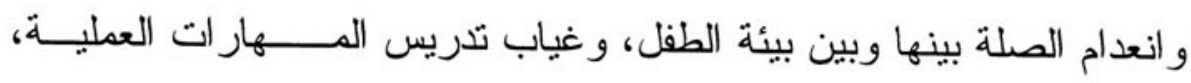

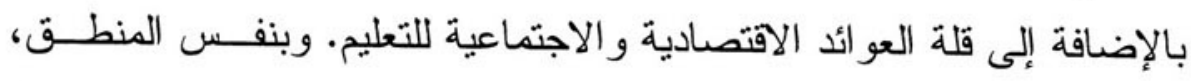

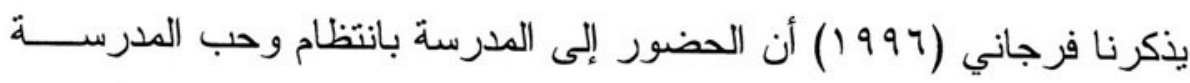
هي عو امل مهمة في تحديد ما إذا كان الطفل سيكمل التعليم الابتدائي أم لا. هناك حاجة لتوجيه الإنتباه بشكل خاص إلـــى بقـــاء الفتيــات فــي

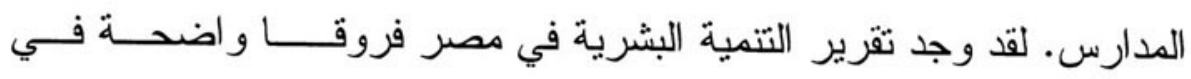

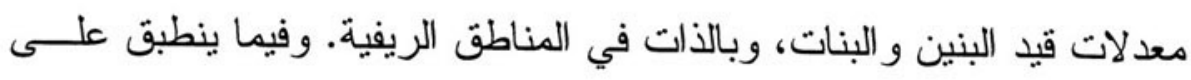

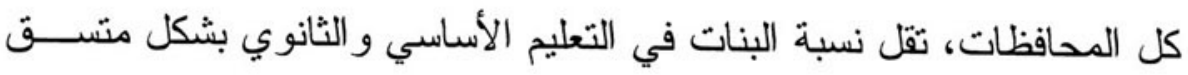

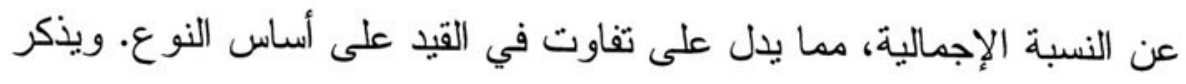

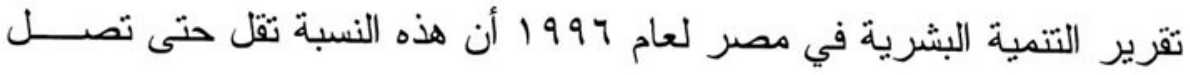

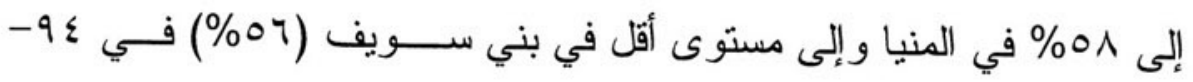


1990. ونجد أن ع \& من البنين في الريف من عمـــر 11-10 مقيـدون

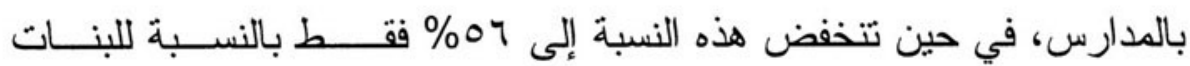
الريفيات في نفس الفئة العمرية. ويستمر هذا الفرق في المجموعة العمريــــة من 17 إلى . r حيث نجد أن ع \&\% من البنين الريفيين مقيدون بالتعليم فـي حين تقل هذه النسبة إلى سr\% فقط بالنسبة للبنات الريفيات. وتتساوى نســبة قيد البنين و البنات فقط في المناطق الحضرية، حيث ع^٪ تقريبا من البنبـن و البنات الحضريين في عمر ||-10 مقيدون بالتعليم، أما في الفئة العمريـــة

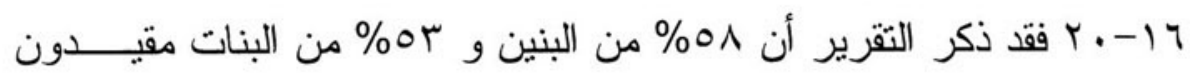
بالتعليم (تقرير التتمية البشرية في مصر ، ب99 1) . ومع ذلك، يمكن أن نعزو الجزء الأكبر من هذه الفجوة إلى التفاوت على أساس النوع في القيد الأصلي وليس للتفاوت في معدلات التسرب (تقرير النشء و التغير الاجنماعى، تحـــ (الطبع).

في حين تشساوى معدلات التشرب بالنسبة للبنين و البنـــات، تختلـــــ أسباب تسرب كل منهما. فكما بذكر المسح الديموجر افي و الصحــي لمصـر (990 (1): "إن معرفة الأسباب التي تؤدي [بالبنات] إلى التسرب من التعليـــم

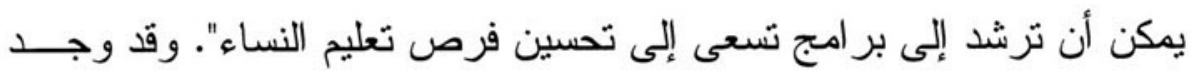

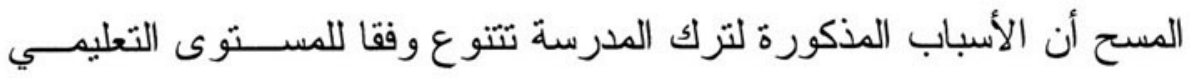
الذى وصلت إليه النساء عند تركهن للتعليم. بالنسبة للنساء اللاتي لم يكملــن التعليم الابتدائي كان السبب الأساسي لتسربهن هو "عــــدم حـــب المدرســـة

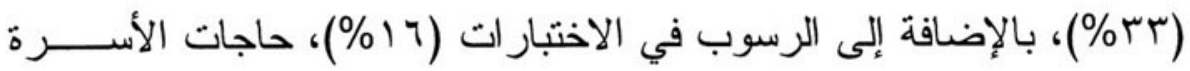

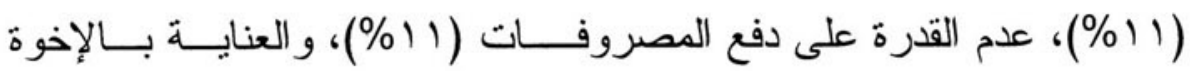
الصغار (^\%). وبالنسبة للنساء اللاتي لم يكملن التعليم الثانوي، حب\% منهن 
تركن المدرسة للزو اج، بالإضافة إلى الرسوب في الاختبارات (rr\%) و عدم حب المدرسة (1) (1).

إن هذه النتائج تقدم أدلة قوية علــى أهميـــة العو امــل الاقتصاديــة

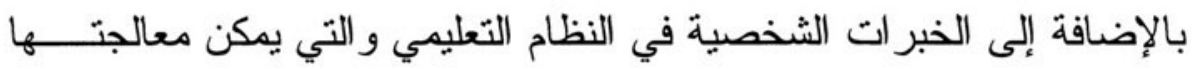

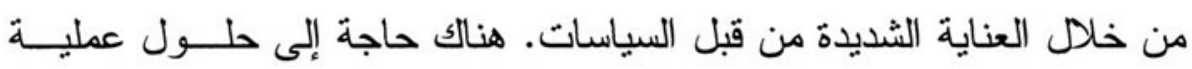
لهذه المشكلات. و على الرغم من أن مدارس الفصل الو احد و المدارس الأهلية

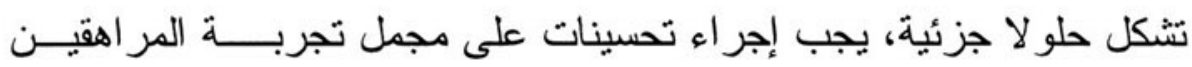

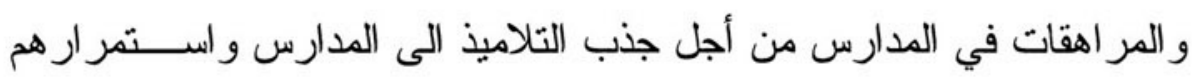
فيها.

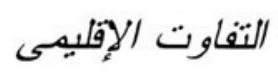

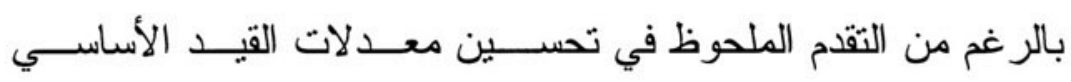

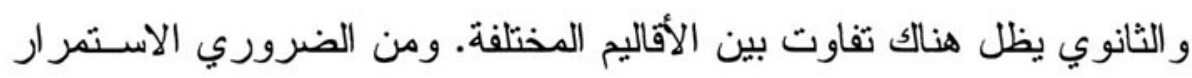

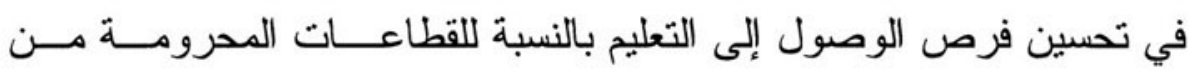

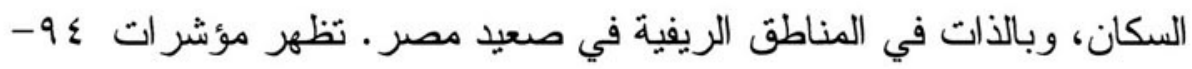

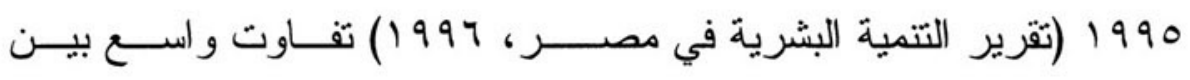
المحافظات المختلفة فيما يخص معدلات القيد في التعليم الأساسي و الثـانوي.

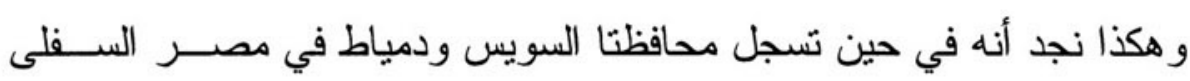
أعلى معدل (9^\%)، تسجل بني سويف و الفيوم في صعيد مصر معدلات أقلى

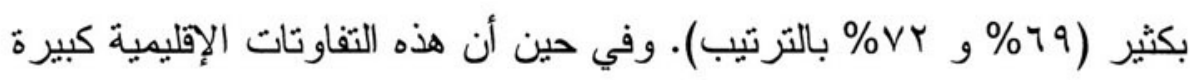

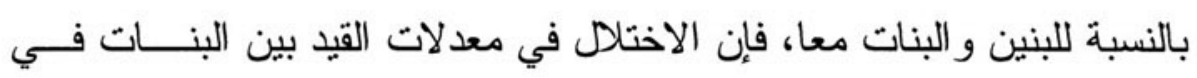

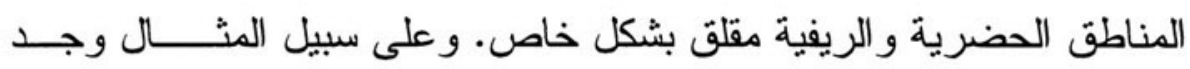
المسح الديموجر افي و الصحي لمصر لعام 1990 أنه بالنسبة للبنات بين سـنـ 
1ا و 1 ، كانت 07 في المائة فقط من البنات الريفيات مقيدات في المدارس، في مقابل ع^ في المائة من بنات الحضر (المسح الديموجر افــي و الصحسـي

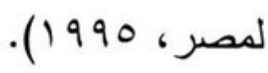

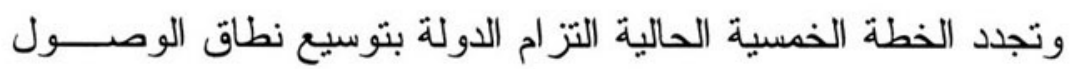
للتعليم في المناطق النائية وذات الخدمات المتذنية. إلا أن إحدى المشـــــات اتلات المزمنة فيما يبدو هي ندرة الأر اضي و الأماكن المناسبة لبناء مدارس جديدة،

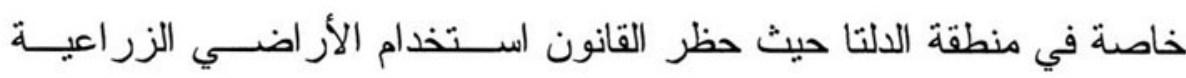
لأغر اض التوسع العمر اني. وفي حالات كهذه، فإن مدارس الفصل الو احد أو المدارس الأهلية قد نكون البديل الممكن. إن تلك المبادرات الر ائدة لا تتخطى

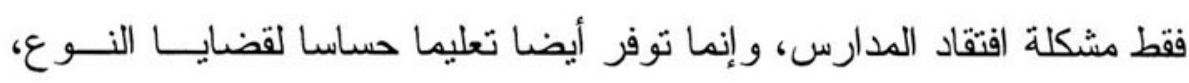
منصلا ببيئته، ومنمحور ا حول التلاميذ.

النو عية

على عكس التحسينات الكمية، فإن إدخال تحسينات كيفية أمر أكـــثر تعقيدا وتكلفة واستنز افا للوقت، كما أنه يكون من الأصعب ملاحظة النتــائج. ومع ذلك، فإن نوعية التعليم عامل يفرث بحق بين الأمم اليوم. على مســتوى الفرد، تحدد نوعية التعليم مستوى المهار ات الأساسية للإنسان، مثل المهار ات اللغوية ومهار ات الحساب وحل المشكلات و القدرة على اســـتخدام التقنيــات الجديدة. و على المستوى القومي، هي محدد جوهري للتنافسية في الاقتصـــاد العالمي.

ووفقا للبنك الدولي، ثتضمن المشكلات الكيفية الأكثر شــــيو عا فـي

مصر محدودية وقت النفاعل بين المدرس و الطالب، وقصر اليوم في مدارس

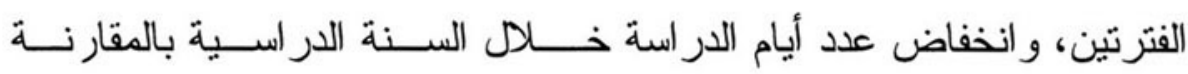


بالمعايير الدولية. كما أن معنويات الددرسين تثـــأثر بــالفصول المتكدســة

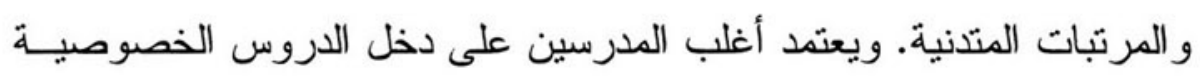

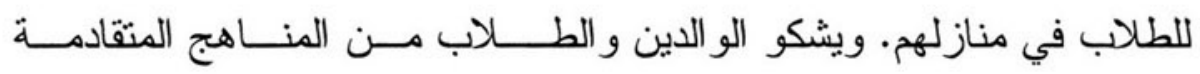

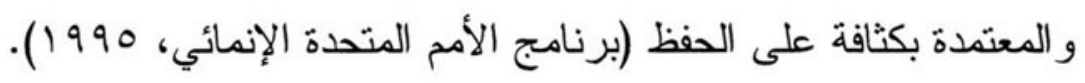
بدأت بعض هذه القضايا الكيفية تنال العناية التي تستحقها. ويعطــــي

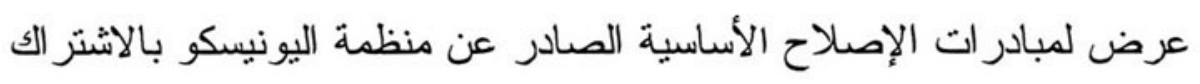

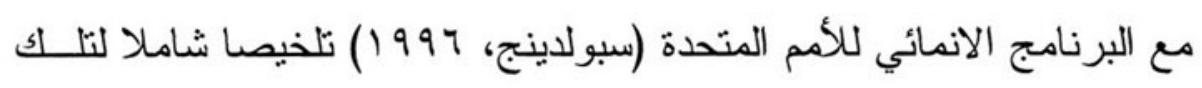

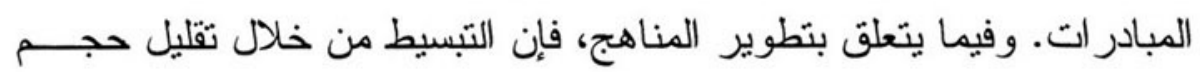

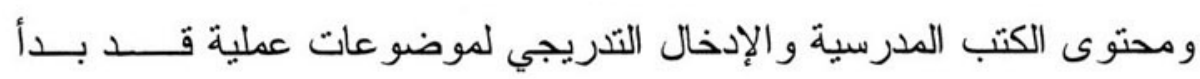

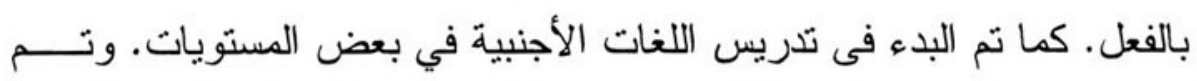

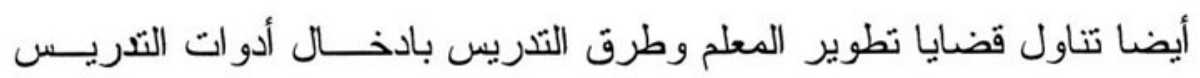

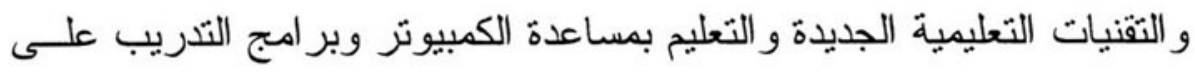

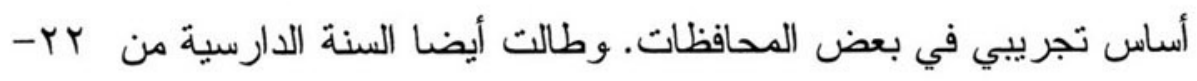

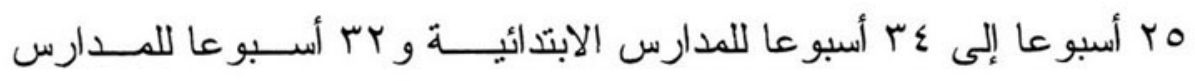

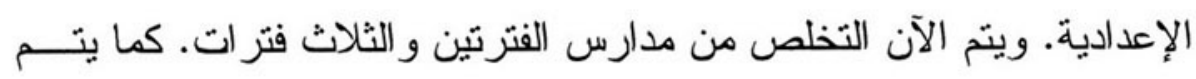

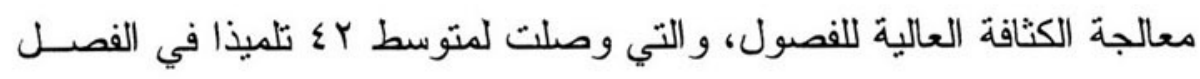

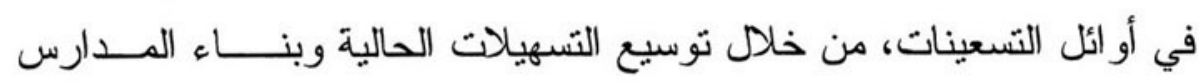

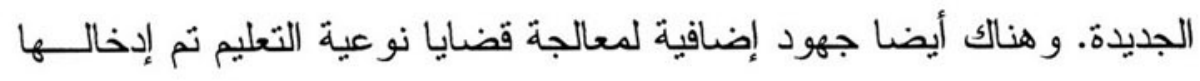
من خلال "برنامج تحسين التعليم" الذي تتبناه وز ارة التعليم بدعم دن الاتحسـاد

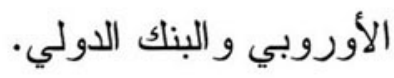

ورغم أن ما سبق يمثل خطوات إيجابية، فإن هناك حاجة لتسر يع قوة

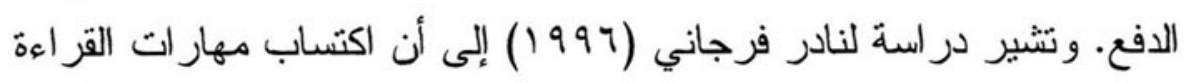


و الكتابة الأساسية قد تدهور منذ أو اخر الثمانينات وأن اكتشــــاب المـــار ات

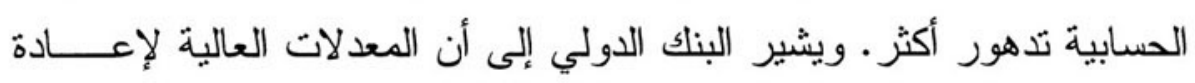

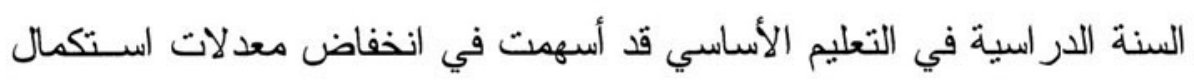
النعليم وزيادة تكدس الفصول.

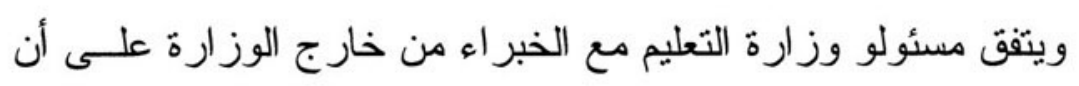

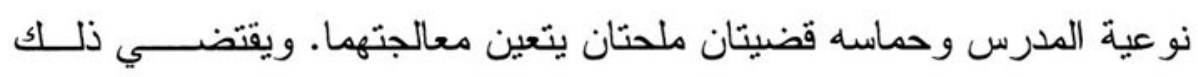

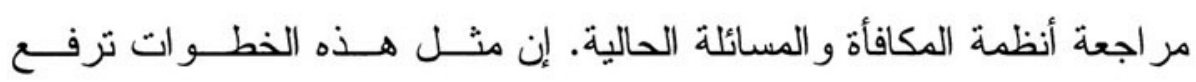

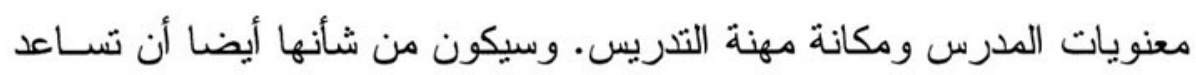

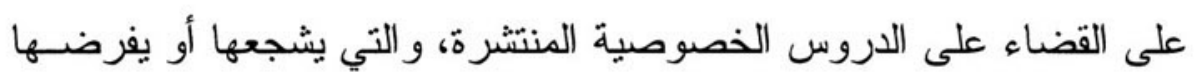

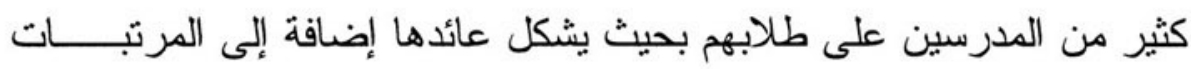

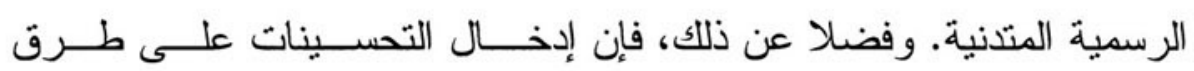
التّريس يمكن أن يزيد من مقدار التعلم داخل الفصول. ويشير أحد المسئولين

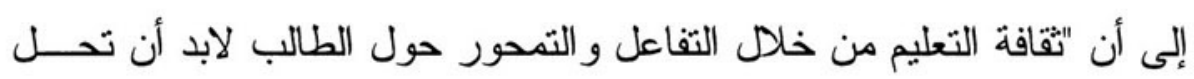
محل الحفظ إذا كان لأي تحسينات ملموسة أن ثرى النور "ل

\section{التدريب المهني}

إن علاقة نظام التعليم بسوق العمل قضية ذات أهمية خاصة بالنســبة

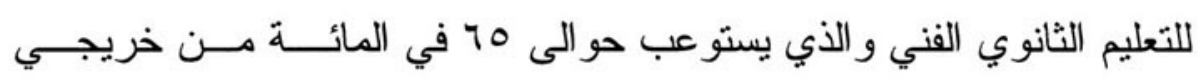

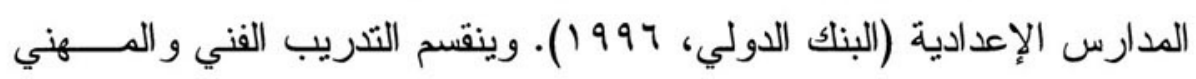

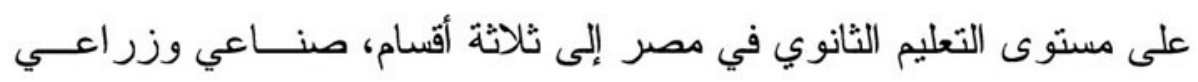

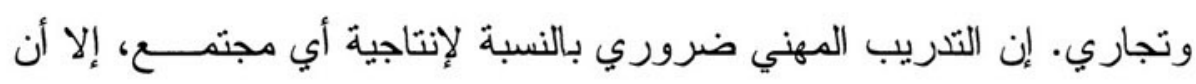

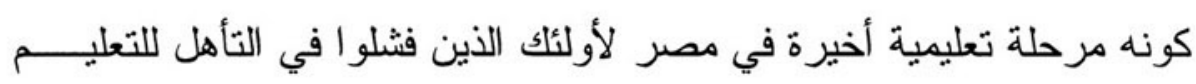

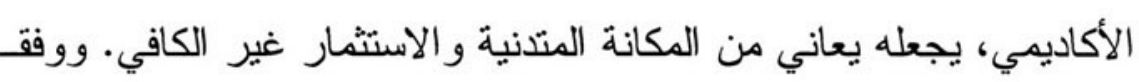


لحداد و آخرين (•99 (19)، نو اجه البلدان على امتداد العالم قضايا مماتلة فــي

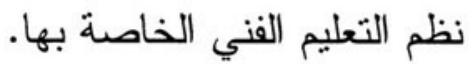

ويو اجه التعليم الفني في مصر حاليا عدة مشكلات. فيبدو الارتبــــاط

ضعيفا بين المناهج الفنية واحتياجات السوق الحالية. ووفقا لبعض المر اقبيـن فإن التدريس يغلب عليه الطابع النظري و لا يتضمن سوى القليل من التذريب

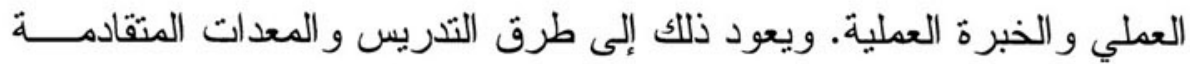

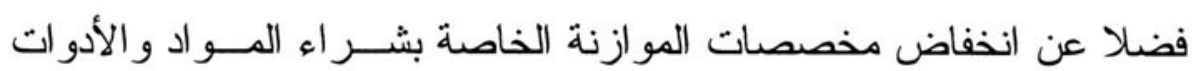
الجديدة وصيانة المعدات. وفضلا عن ذلك، عادة ما تدرس البنات الملتحقـلت

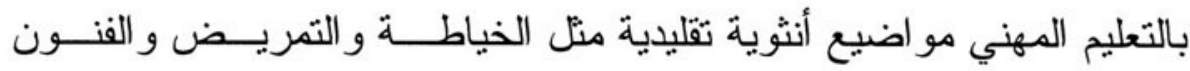
و الخزف ورعاية الأطفال و الاقتصاد المنزلي، وهو ما يحد وفقا للبنك الدولي لئي

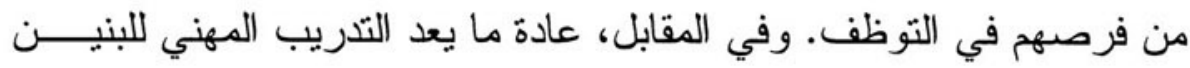
لمهن أكثر إدرار اللاخل في الصناعة أو البناء.

تتضمن المحاو لات الر اهنة لاصلاح التعليم المهني مبادرة مبــارك-

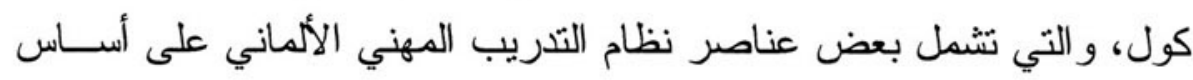

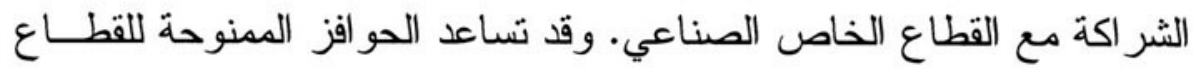

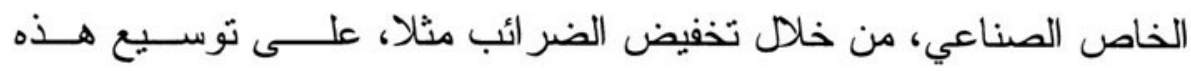

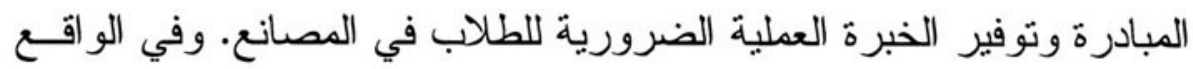

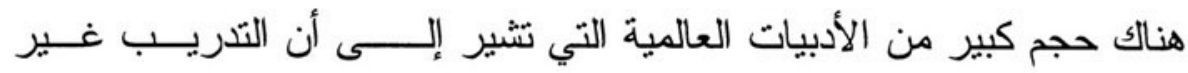

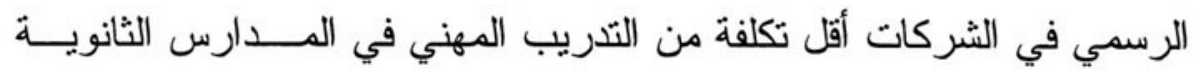

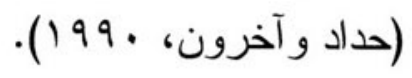


رغم كونه مجانيا من الناحية الدستورية، فإن الحصول على التعليــم العام في مصر اليوم يصاحبه نفقات كبيرة، مباشــرة مــن خــلال الرســوم و المصروفات، أو غير مباشرة من خلال الـــدروس الخصوصيــة والــزي

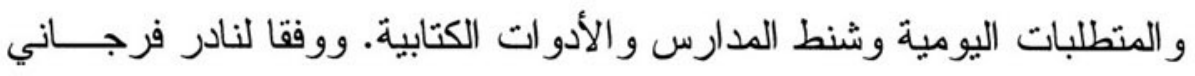
(797 (1)، قد تصل النفقات السنوية للطالب في المنتوسط إلى . PO جنيه فـي التعليم الابتدائي، وهو مبلغ كبير بالنسبة للأسر محدودة الدخل ذات العديد من

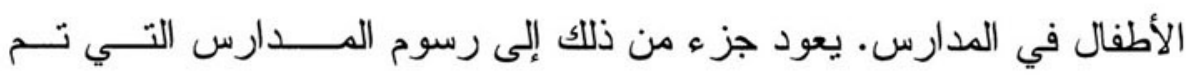
إدخالها مجددا خلال السبعينات في صورة آلية لتغطية النفقات. ويقرر نـــادر

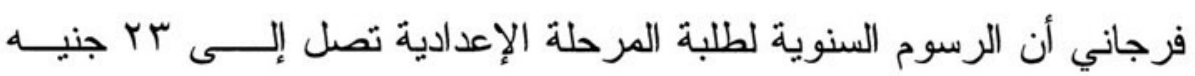
للطالب. وتحدد البحوث التي تم الرجوع إليها فيما سبق التكلفة كعامل مـــــهم في معدلات الالتحاق الأصلي و البقاء في المدارس. وبالفعل وجد فرجـلني أن الفقر يمثل عقبة تحول دون الالتحاق أصلا بالمدارس كما تؤثر ســلبا علــى

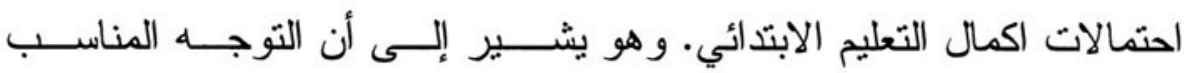
للسياسات يتمنل في توفير آليات دعم اجنماعي كافية وفعالة وغير موصومسـة

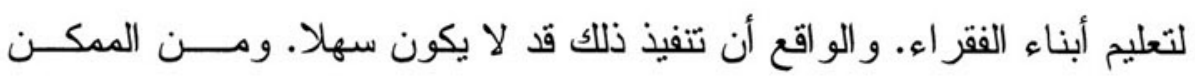

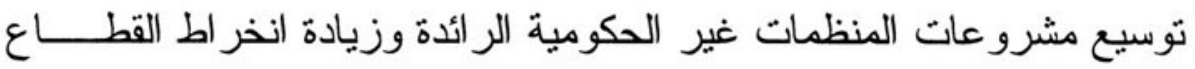
الخاص في شئون المجتمعات الفقيرة داخل دو ائر عمله الإقليمية. وتثضــــن الحلول غير التقليدية توفير المنح الدراســـية للبنــات الصغــيرات، وجعـلـ الخدمات الاجتماعية مشروطة ببقاء الأطفال في المدارس، وادخـــال بر امـــج عمل/در اسة لأولئك الذين لم يدخلوا المدارس أو تركو ها مبكر ا.

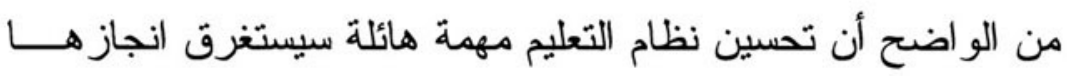

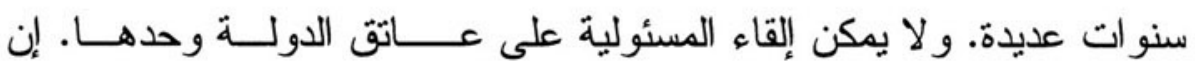




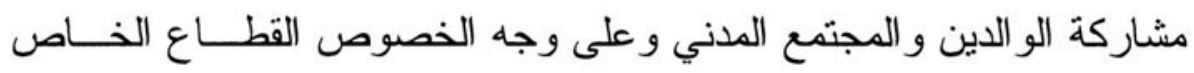
ضرورية. وتسنطيع الدولة أن تلعب دورا مهما عن طريث تعزيــز أثــكال الشر اكة و إعداد خطة شاملة لتتسيق ومتابعة وتقييم التقدم. 
يمكن تعريف صحة المر اهق بانها الحالة البدنية و الذهنية و العاطفيـة

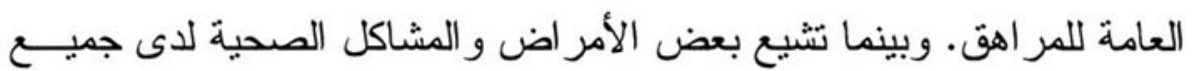

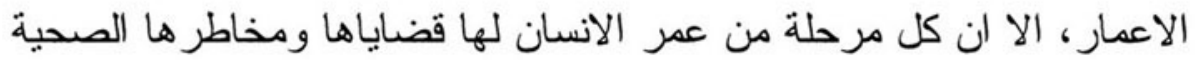
الخاصة. وقد ركزت العلوم الطبية و التخصصات النقليدية على مر احل عمـر

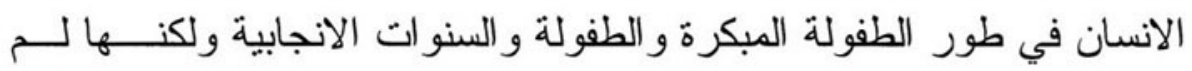
تولى اهتمام كاف بالحاجات الخاصة لمن هم في طور المر اهقـــة. غـــير ان

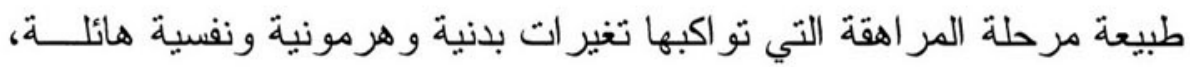

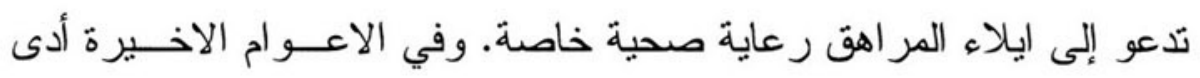

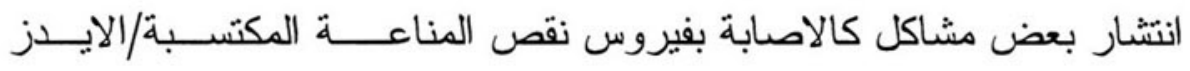
وتعاطي المخدر ات و التدخين وكذلك بعض الاضطر ابات السلوكية و النفســـية

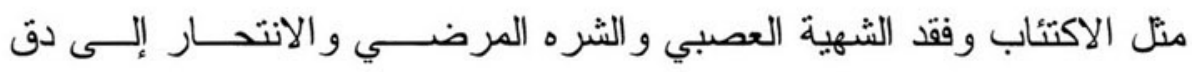

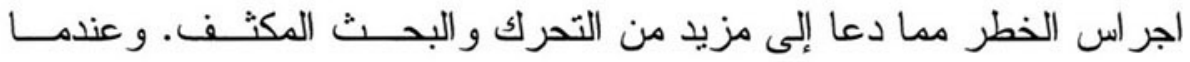
رعت الامم المتحدة المؤتمر الدولي للسكان و التنمية الذي عقد في القاهرة عام ـ99 199 وفي مصر عني القليل من البحوث بصحة المر اهق قبل المؤتمر ـوقد

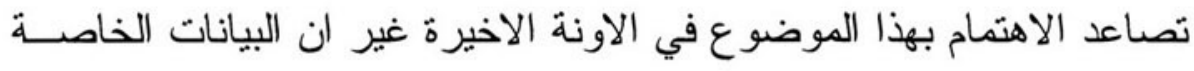

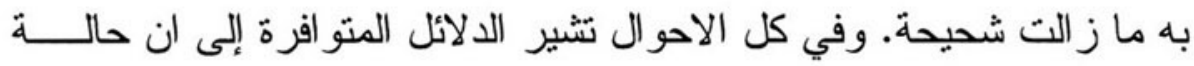

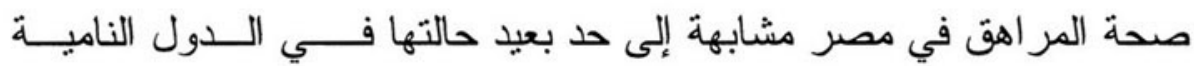

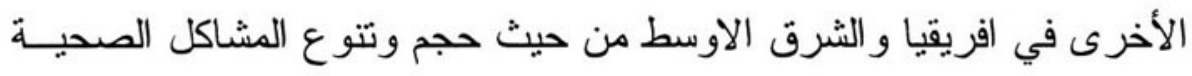

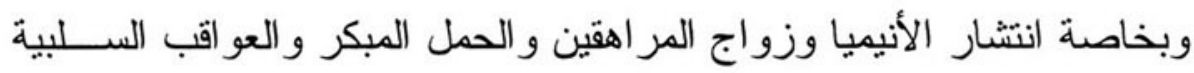

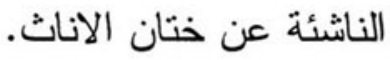


ان صحة المر اهق أمر مهم بالنسبة للدولة ليس فقط لانها تؤثر علىى

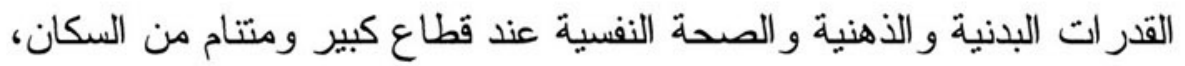

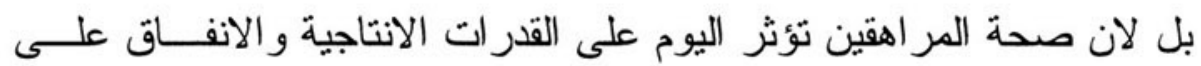

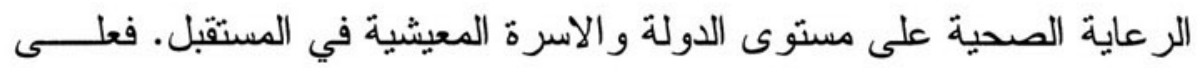

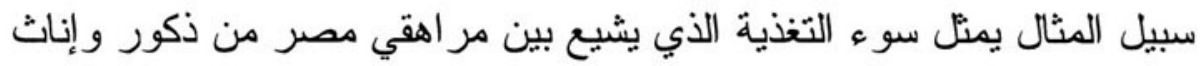

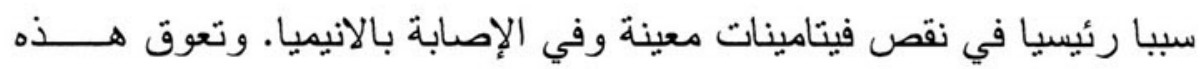

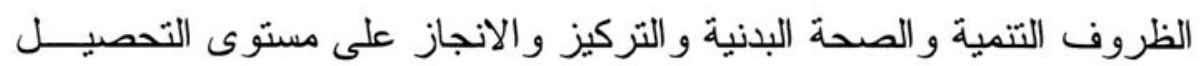

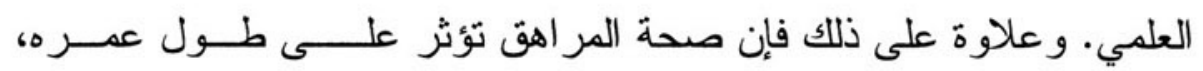

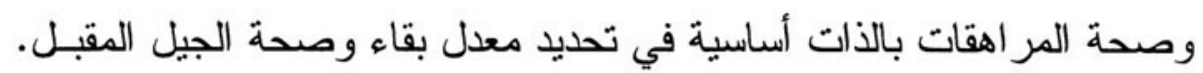

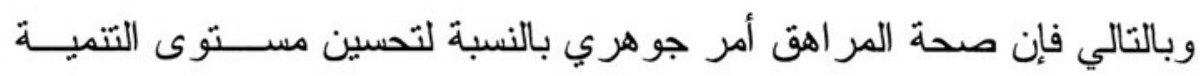
البشرية و الاقتصادية في البلاد.

\section{العو امل المحددة لصحة المراهق في مصر}

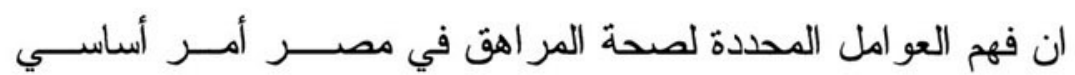

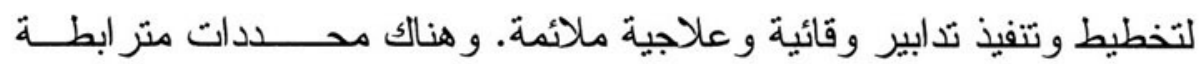

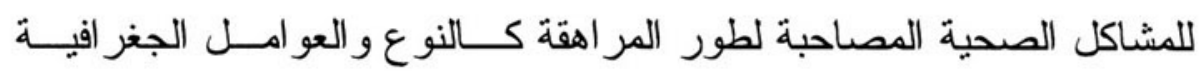
ومستوى التغذية و الوضع الاقتصادي الاجتماعي و الثقافة و الثقاليد و العنــاصر

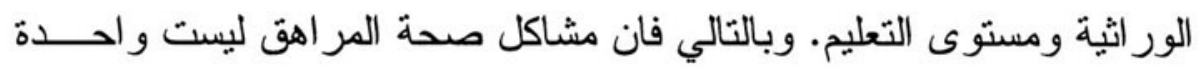

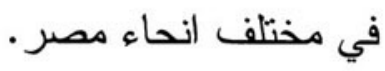

وتتنج التمايز ات في النوع من الفروق البيولوجية و الموروثة على حد

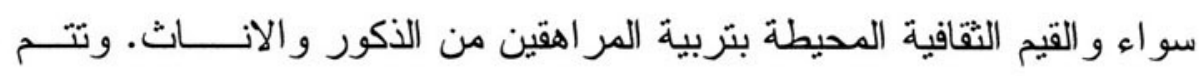

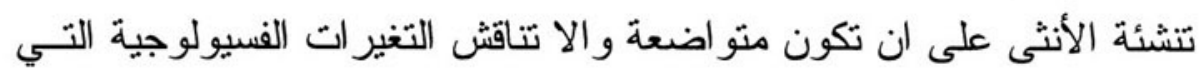

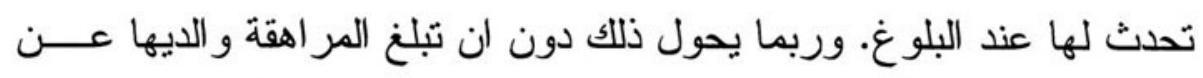

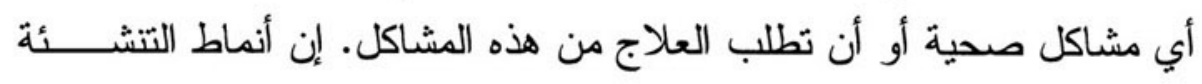


الاجتماعية عند الذكور التي تو اكبها ضغوط الاقران و الرغبة فـــي خــوض فئس

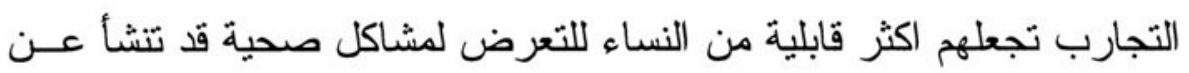

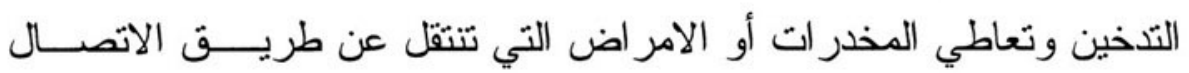

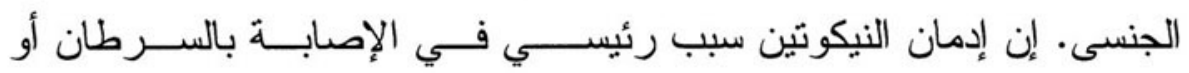

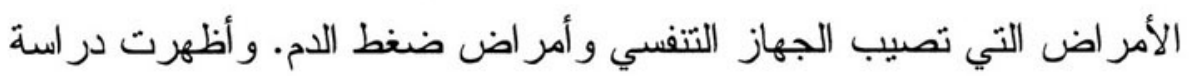
أجرتها وزارة الصحة و السكان في عام ـ199 أن من بين سنة ملايين مدخن

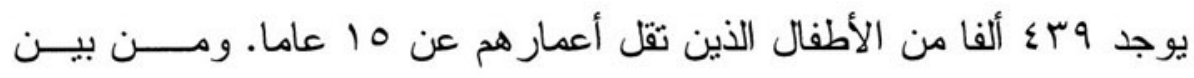

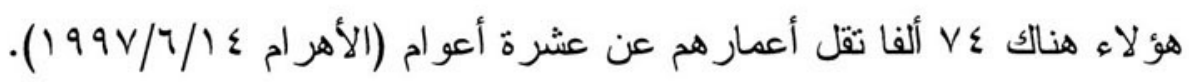

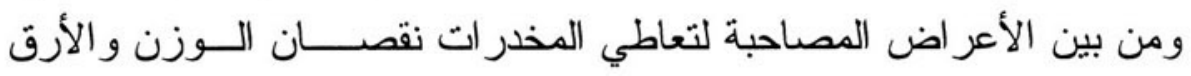

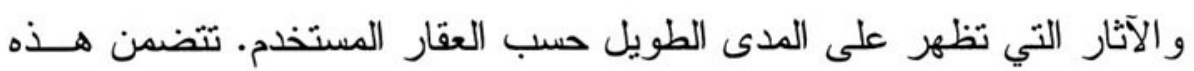

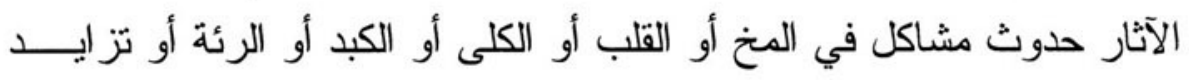
مخاطر الإصابة بفيروس نقص المناعة المكتسبة أو الالتهاب الكبدي الوبـائي

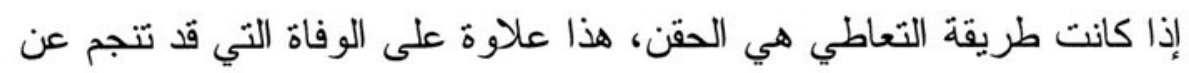

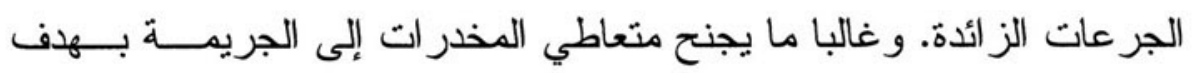

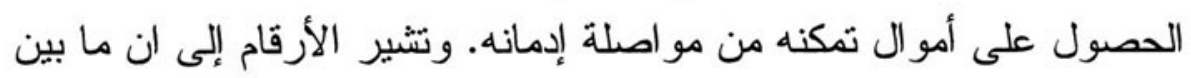

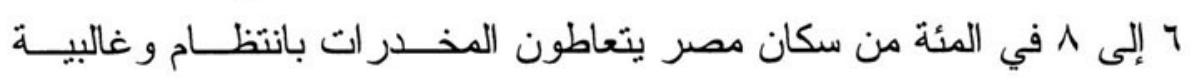

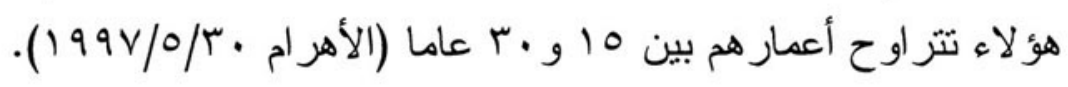
و عندما تصل الإناث في مصر إلى سن المر اهقة يكن قـــ تعرضــن

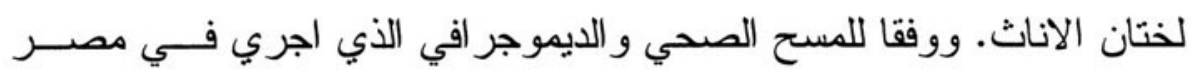

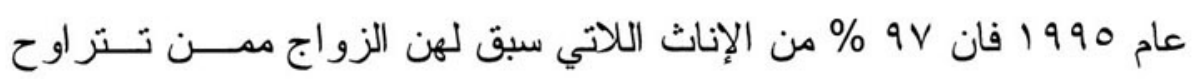

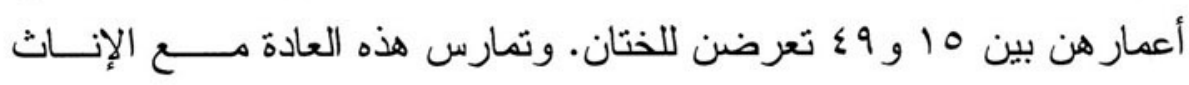

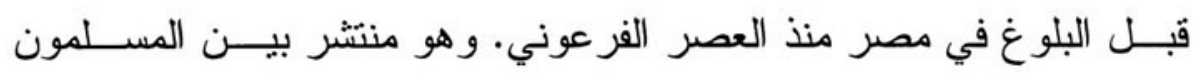

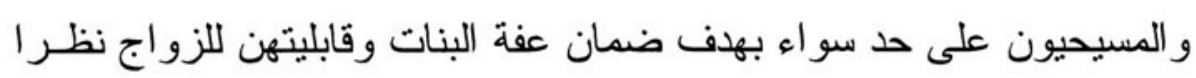


للاعتقاد بان هذه الممارسة تحد من الشهوات الجنسية. كما اظهر المســـح ان

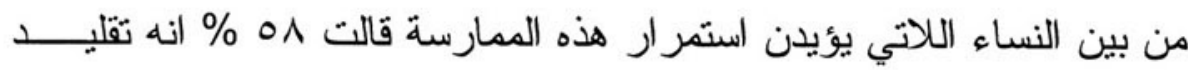

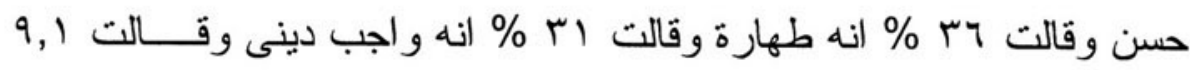

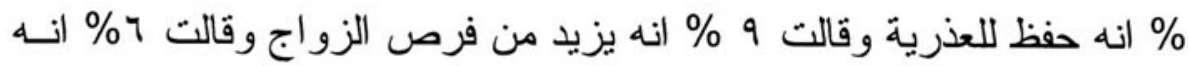

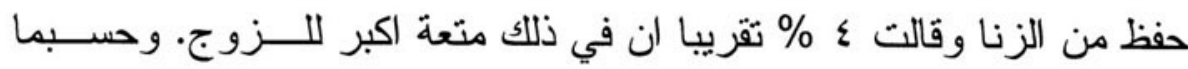

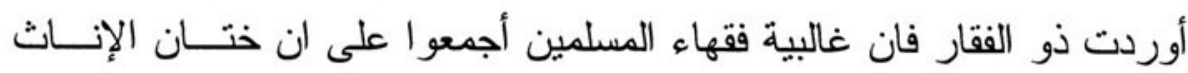

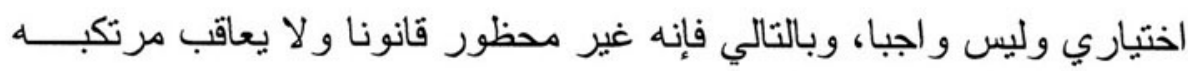
وفقا لقانون العقوبات (ذو الفقار ، 990 (1).

وقد يؤدي ختان الاناث إلى تعقيدات بدنية ونفسية عند الأنثى. ويشير

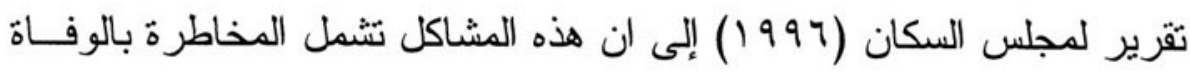

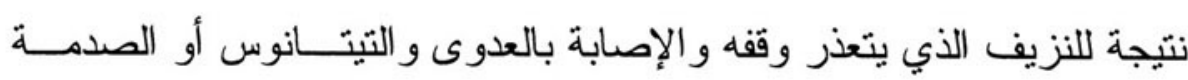

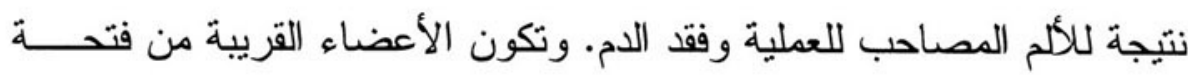

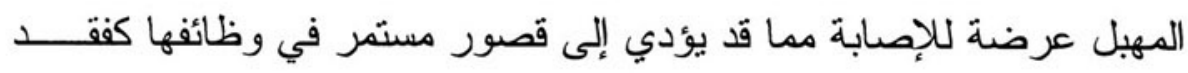

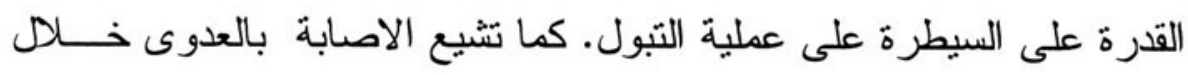

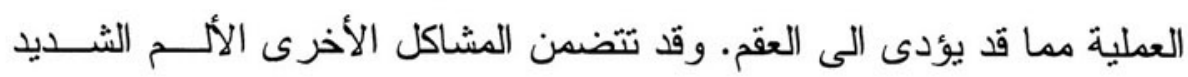

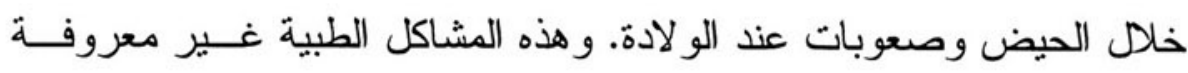

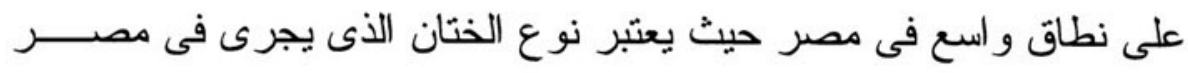

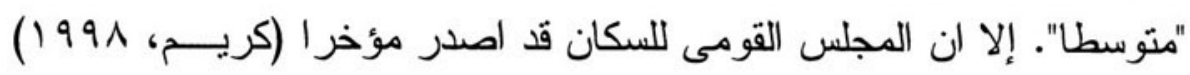
كتيبا لنشر الوعى العام حول المخاطر الصحية و النفسية لختان الاناث. ويو اجه المر اهقون المتزوجون مزيدا من المشاكل في غياب وســائل

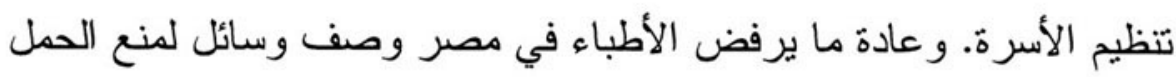

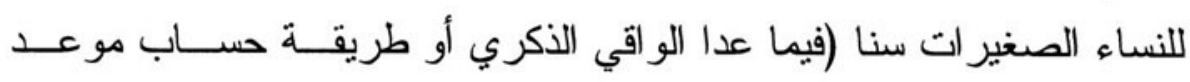

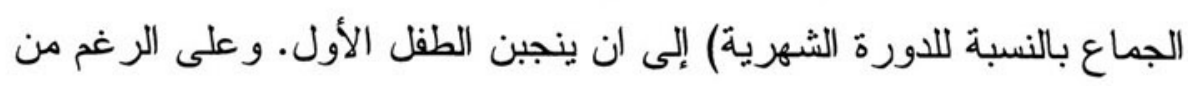


ان هذه الممارسة ليست سياسة أو إجر اء مكتوبا فانها تمارس علـــى نطــاق

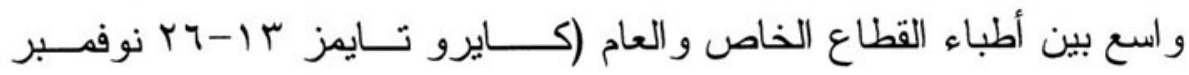
.)( 1997

ان التغذية عامل آخر مهم لصحة المر اهق. ويعتمد الوضع الغذائــي

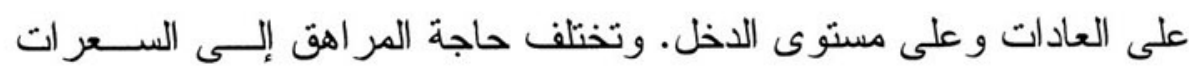

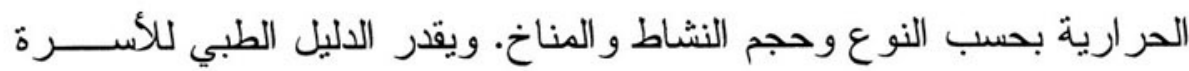

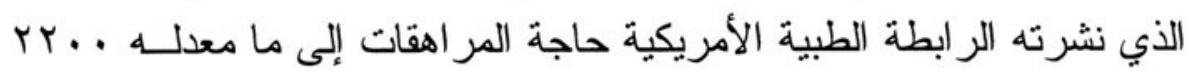

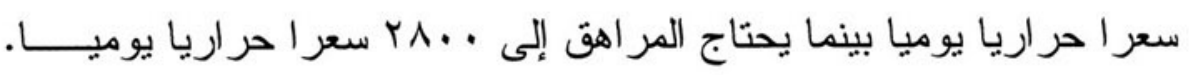

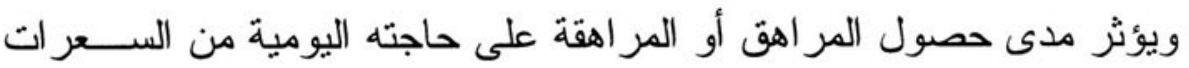

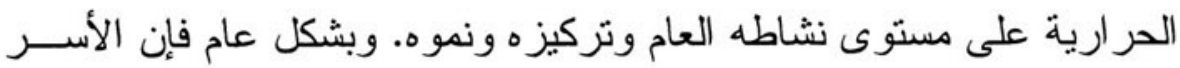

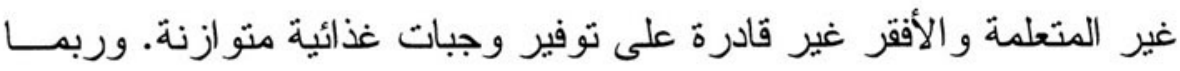

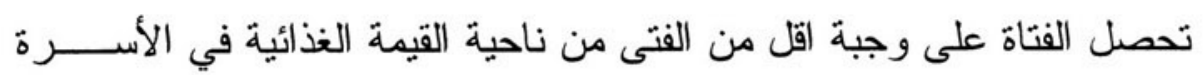

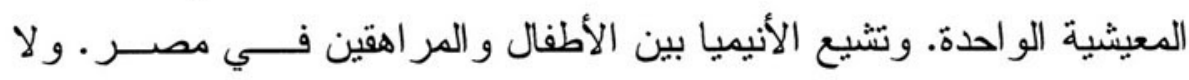

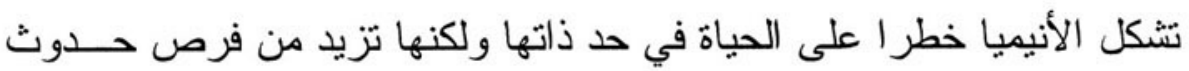

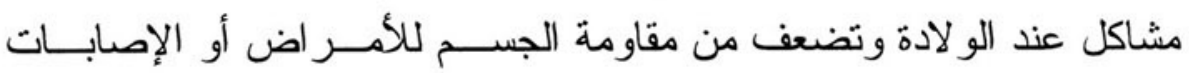

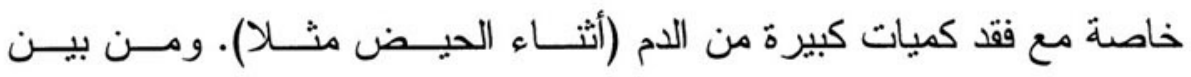

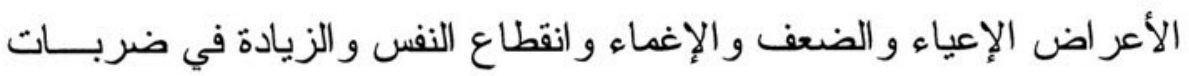
القلب.

و هنالك عامل آخر يؤثر في صحة المر اهق هو التعرض للمخـــــاطر

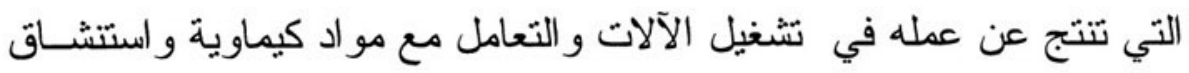

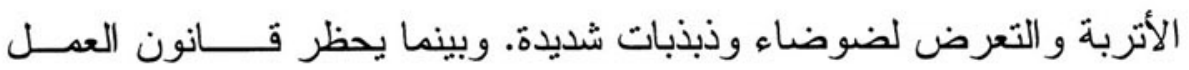

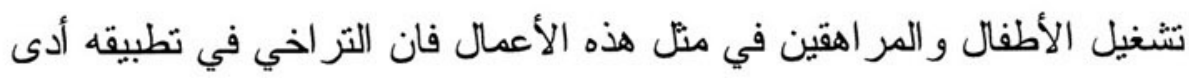

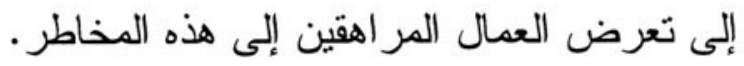




\section{السياسة الصحية في مصر}

تعتمد السياسة الصحية في مصر على المادة 17 من الدستور التــي

تنص على ان الرعاية الصحية حق أساسي لجميع المواطنين ويتعين ان يتمتع

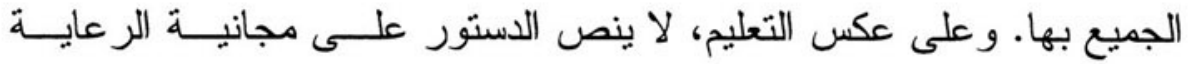

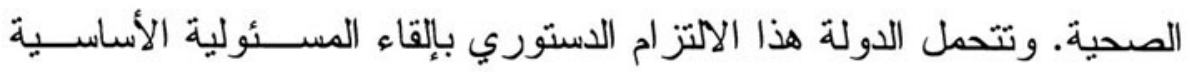

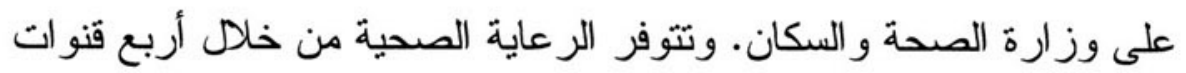

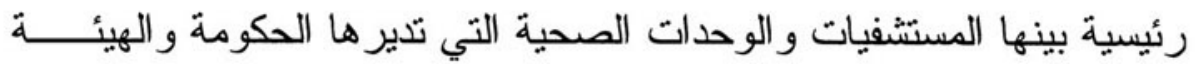

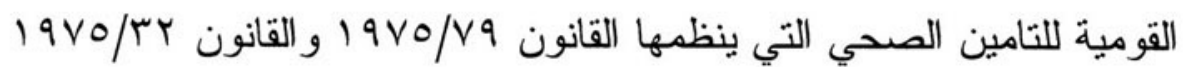

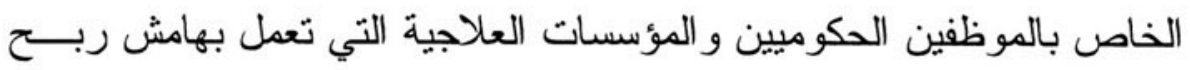
ضئيل وكذا المر افق الخاصة من مستشفيات وعيادات (الهيئة القومية للتـأمين

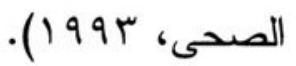

وفي الوقت الحاضر تسعي وزارة الصحة و السكان إلى تحقيق هـدف

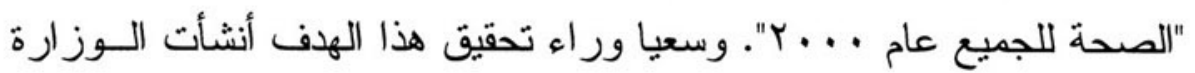

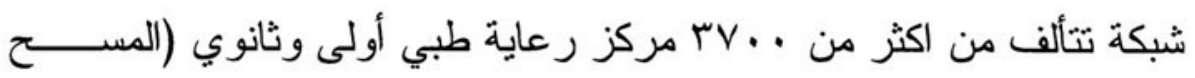

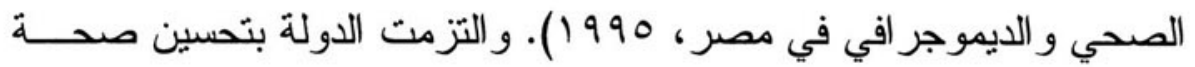

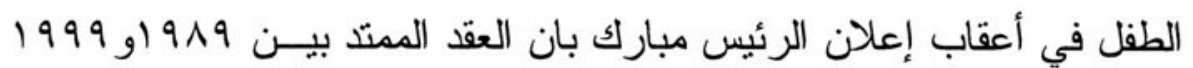
هو عقد حماية وتطوير الطفل المصري.

طر أ تحسن ملموس على صحة السكان في مصر • و أسهمت التدابـير

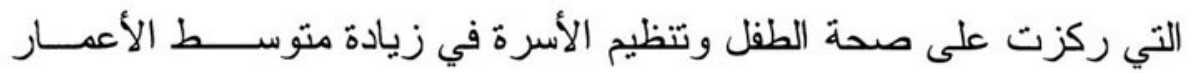

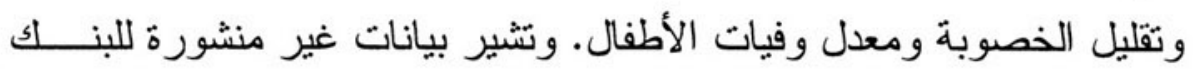

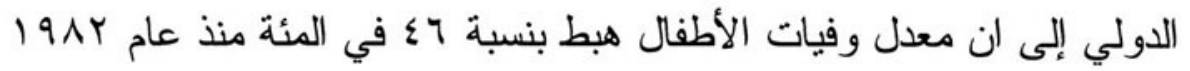

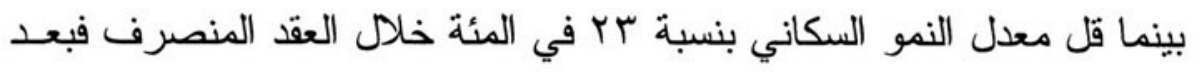


ان كان معدل النمو السكاني في مصر بر ب في المئة اصبح ؟ فـــي المئــة

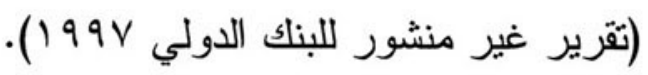

و على الرغم من هذا التقدم ظلت الأوضاع الصحية عنــــ قطاعـات

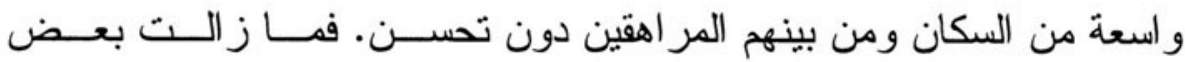

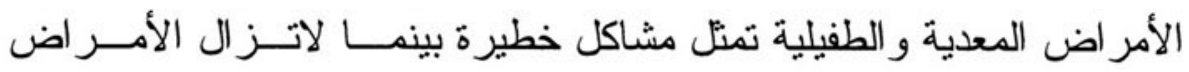

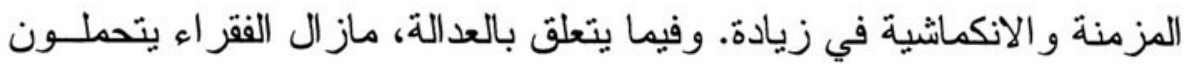

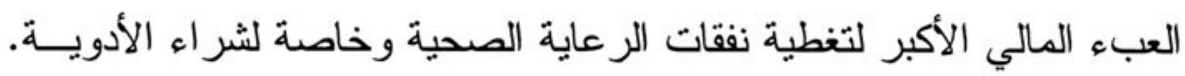

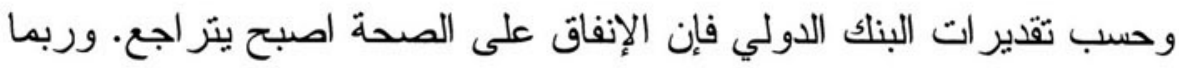

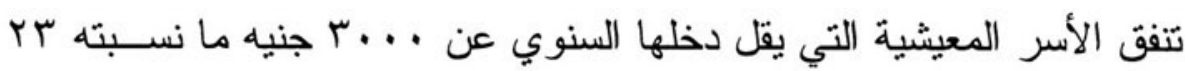

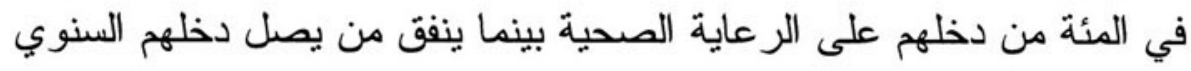

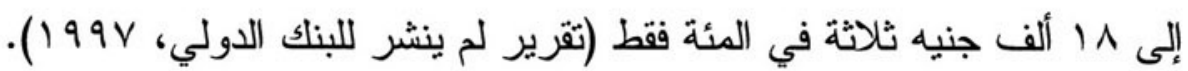

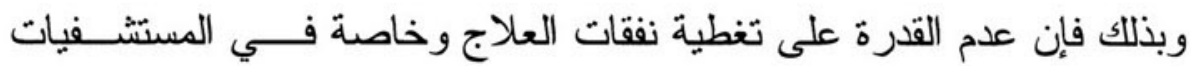

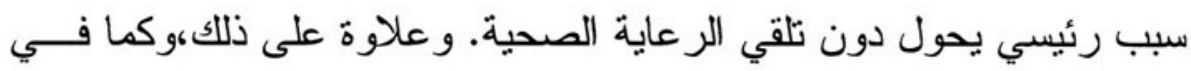

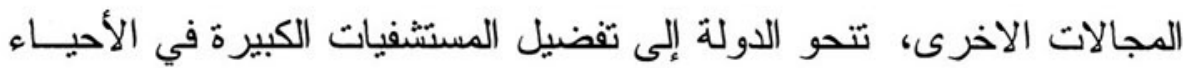

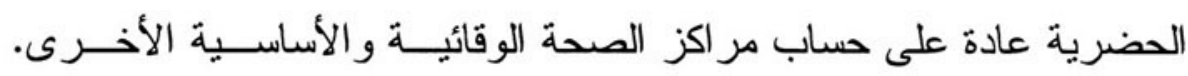
وفضلا عن ذلك فإن هناك إجماعا على ان نوعية الخدمات يمكن تحســـــــــا.

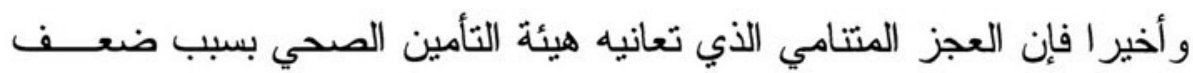
تحصيل الاشتر اكات يهدد استمر ارها على المدى البعيد.

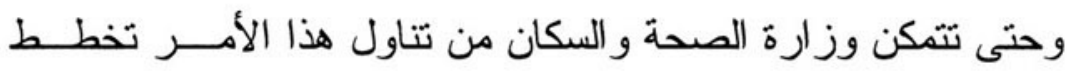
الوز ارة لإجر اء إصلاحات في القطاع الصحي بهدف تعديم التأمين الصدي.

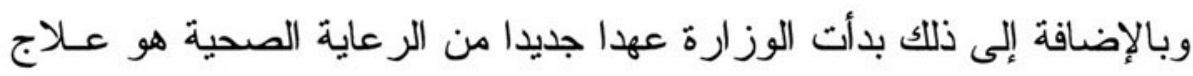

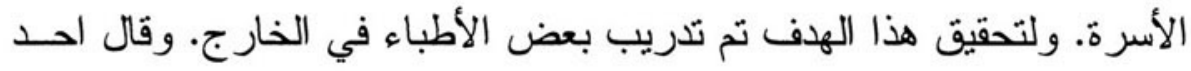

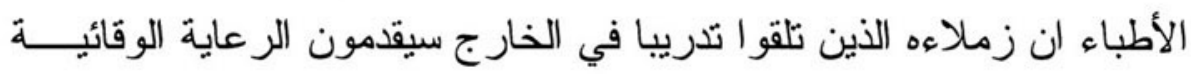


و العلاجية للأسرة بــأكملها. و هؤلاء اكثر قدرة على الوصول إلى تشـــيص

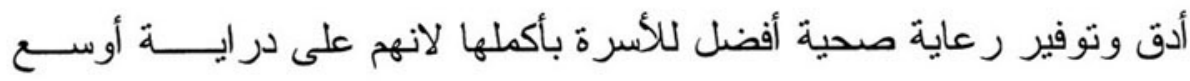

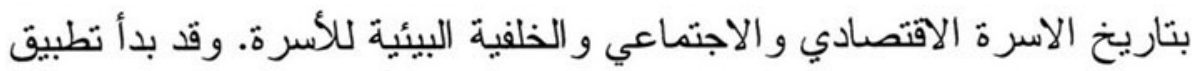
هذا البرنامج في ثمان محافظات ومن المتوقع تعميمه. وتخطط الوز ارة لتحسين الرعاية الوقائية و العلاجية وتستهدف تقديـم

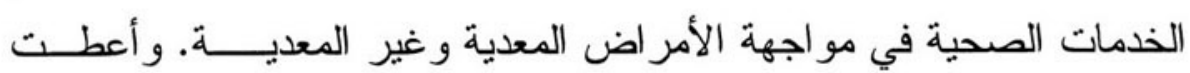

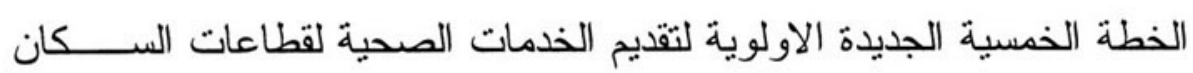

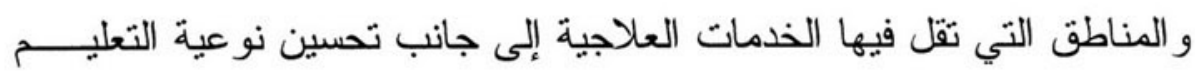
و التغذية و الصحة الانجابية و الصحة البيئية.

وبينما لا تثطرق الخطة الخمسية الجديدة إلـــى صحـــة المر اهقيــن

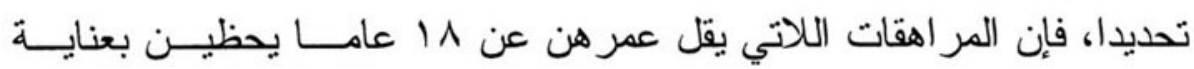

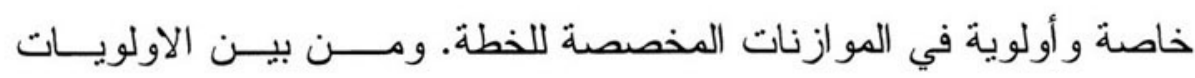

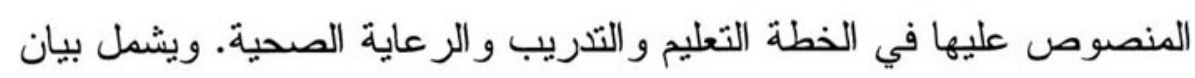

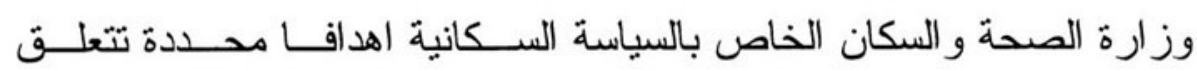
بالمر اهقين (انظر الفصل الرابع).

\section{برنامج التأمين الصحي لطلاب المدارس}

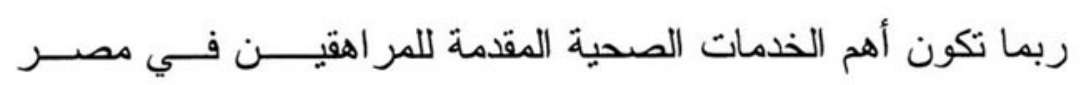

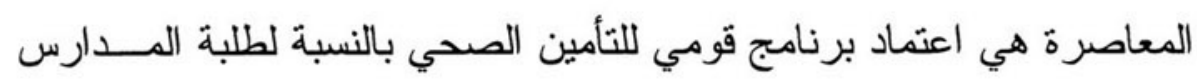

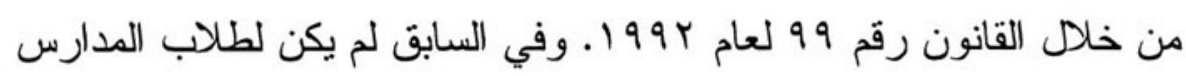

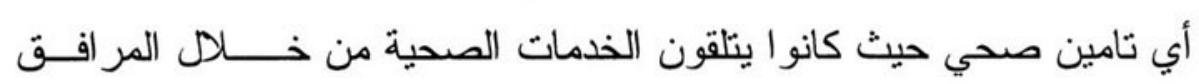

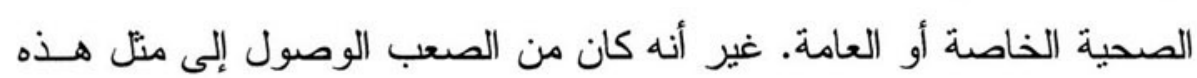

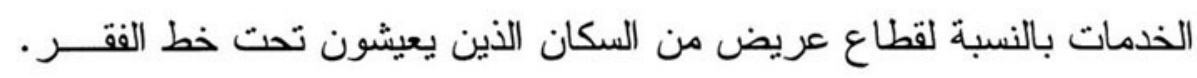


وبدأ العمل بهذا البرنامج ليكون "شبكة امان" تدير ها الحكومة بتمويــــل مــن الضر ائب التي تجبى من مبيعات السجائر وتبر عات رمزية من المنتفعين.

ويوضح القانون 99/99/9 19 نطاق فعالية هذا البرنامج وطريقة عمله.

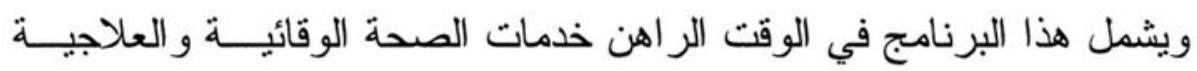

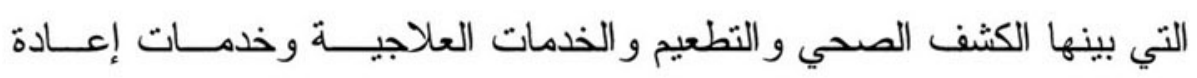

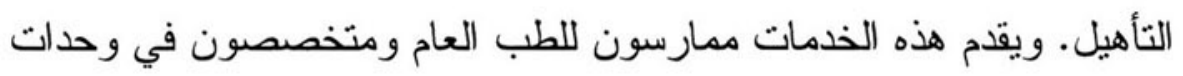

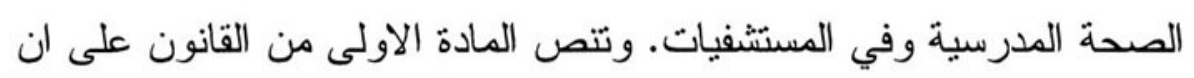
برنامج التأمين الصحي المدرسي يشمل الطلاب في مر احل الحضانة و التعليم الاساسي و الثانوي العام و الفني و المدارس الفنية و المدارس الثانوية التجريبيـة فئنة

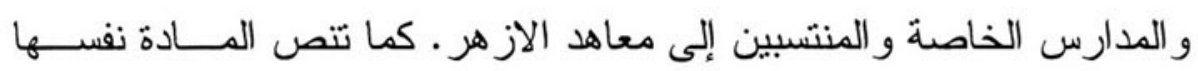

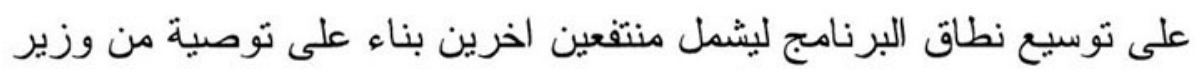
الصحة برفعها إلى رئيس الوزر اء.

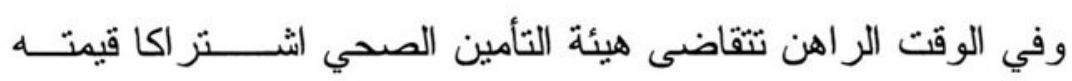

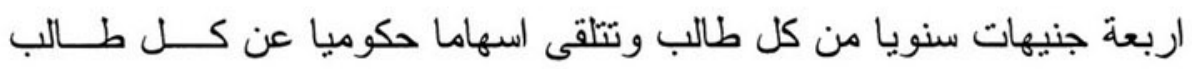

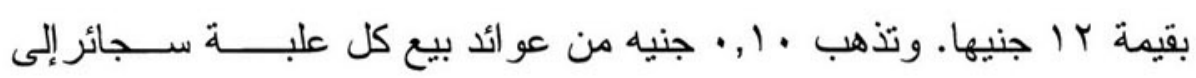

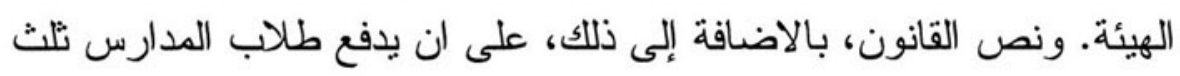

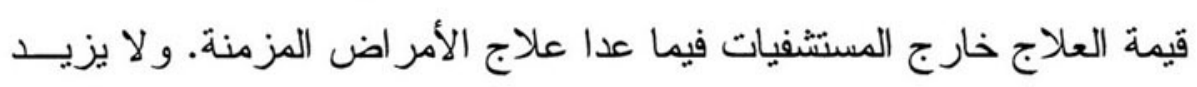

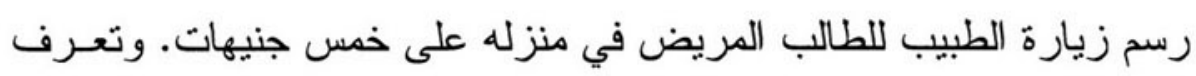

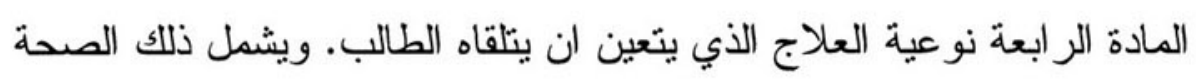

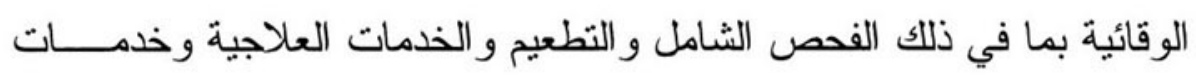
اعادة التأهيل. 
ومن اجل مزيد من التنظيم لهذه العطلية جاء قانون الطفل لعام 1997

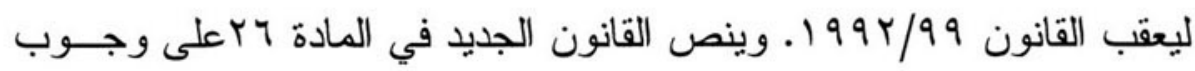
ان بحمل كل طفل بطاقة صحية. ويتطلب القانون ان تدون البيانات الموجودة

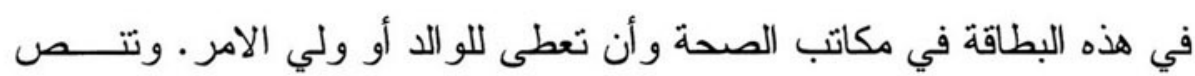

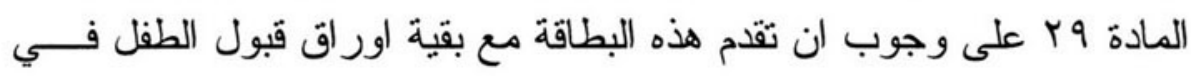

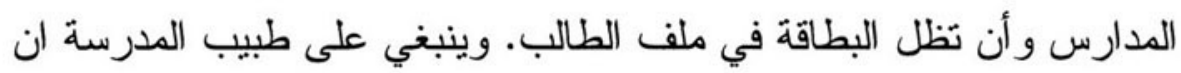
يدون التطور ات التي تطر أ على صحة الطفل في هذه البطاقة.

بعض التحديات التي تواجه برنامج التأمين الصحي لطلاب المدارس حتى هذه اللحظة قدم برنامج التامين الصحي للطلاب مظلة للخدمات

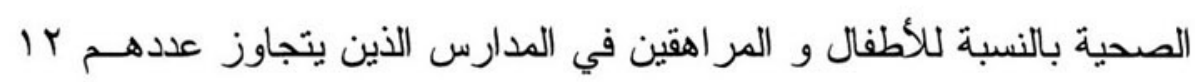

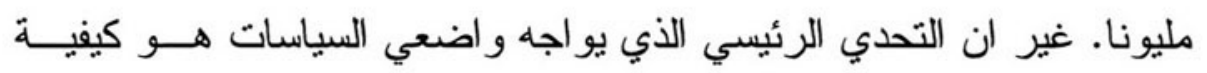

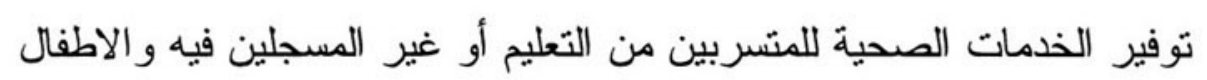

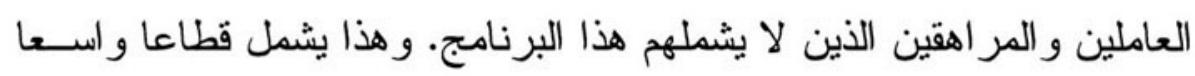

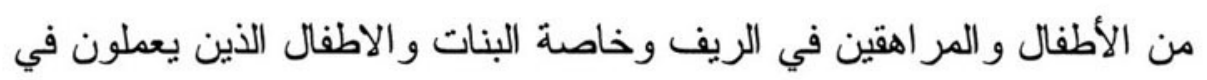
القطاع غير الرسمي و أطفال الشوارع.

وتعكف وز ارة الصحة و السكان بالتعاون مع الـــوز ارات و الـــيئات الأخرى كوز ارة التربية و التعليم ووزارة الشؤون الاجتماعية و القوى العاملـــة

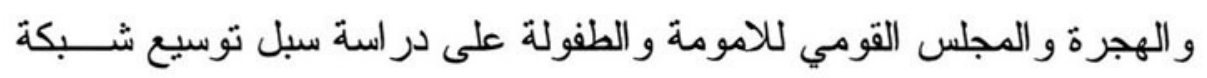

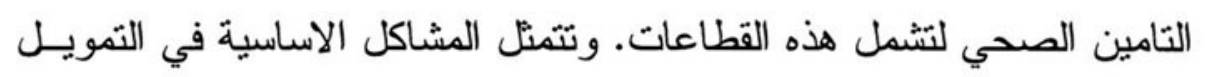
و استحداث اطار قانوني ومؤسسي لتسيير العمل مع هذه القطاعات.

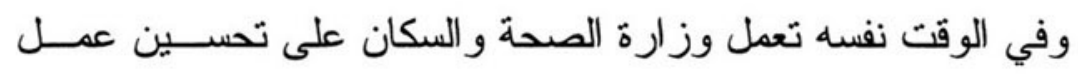

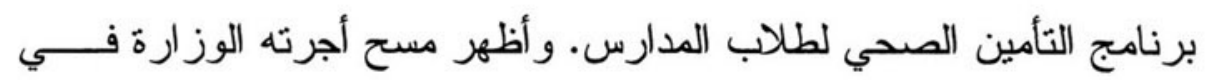


r 199- 199 19 يغطي •r مب مدرسة في ست محافظات (القاهرة و الاسكندرية

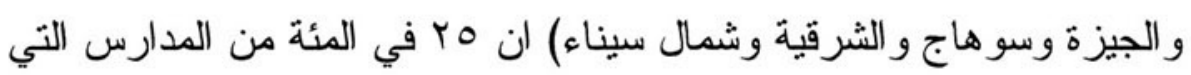

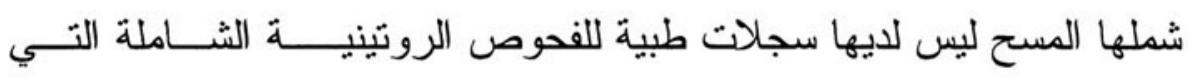

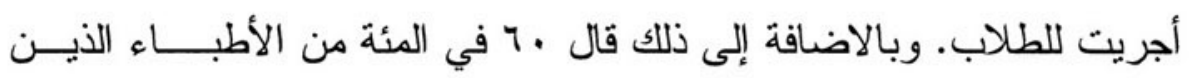

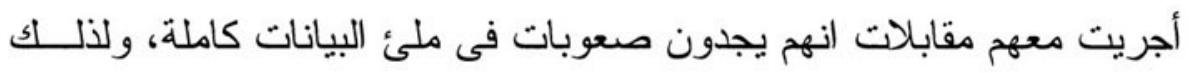

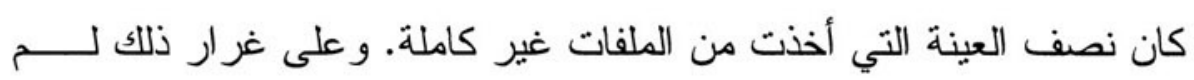

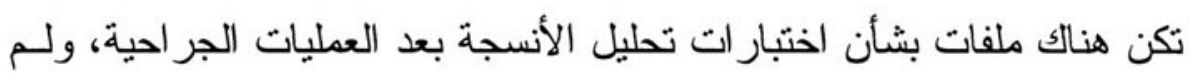

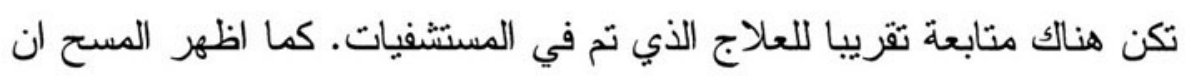

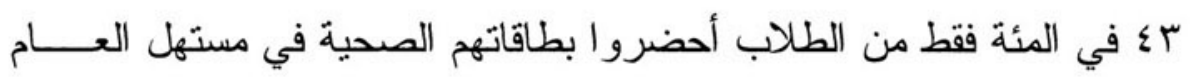

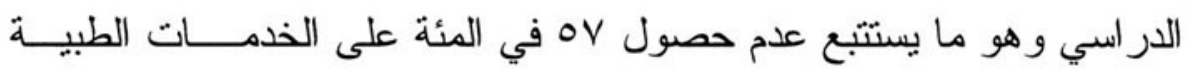

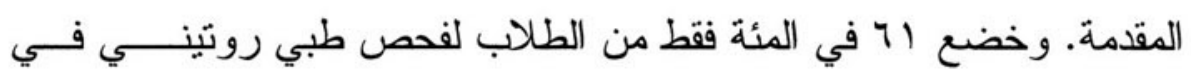

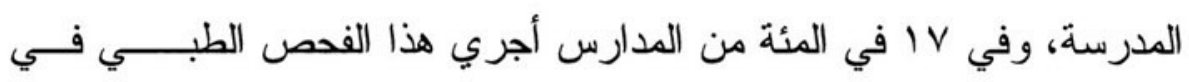

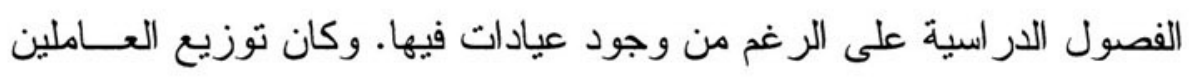

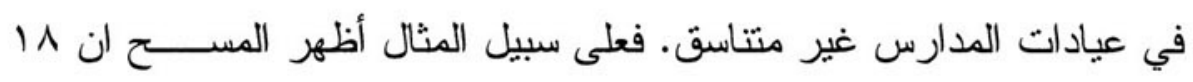

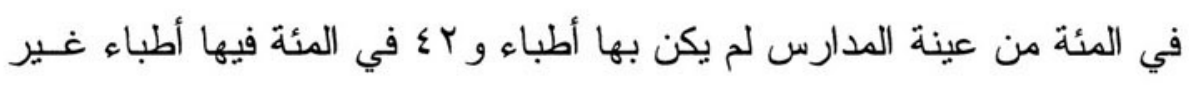

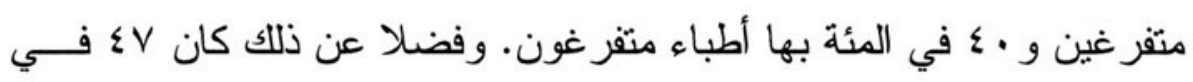

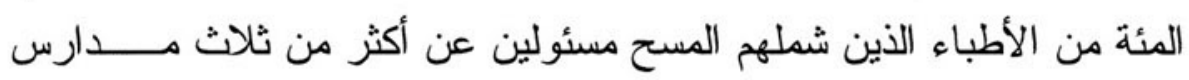

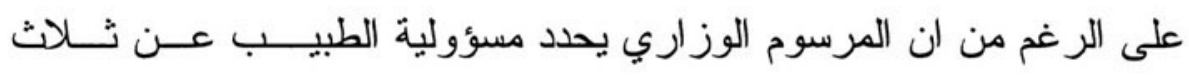

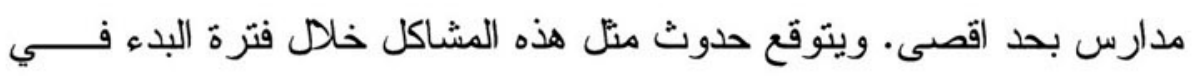
هذا البرنامج الطموح ولكنها تدعو إلى تكثيف الرقابة و الحاجة الى التذخل. 
أولويات أخرى للعمل إدمان النبكوتين والمخدرات

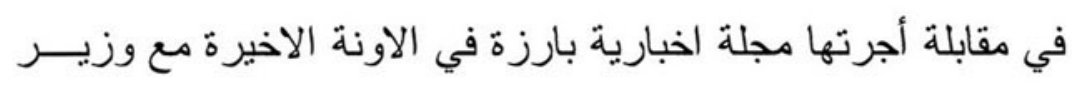

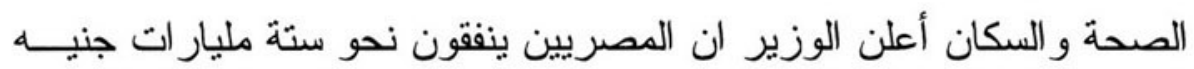

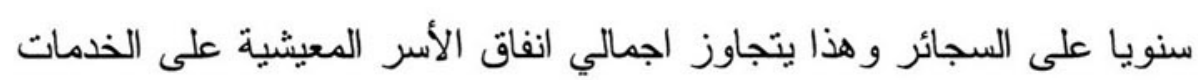

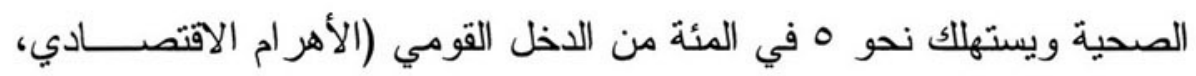

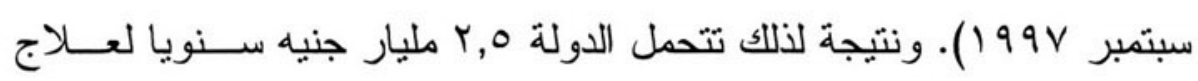

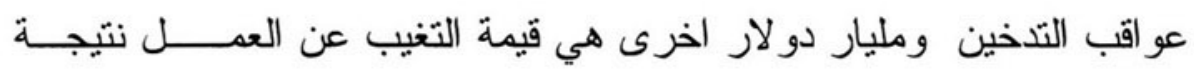

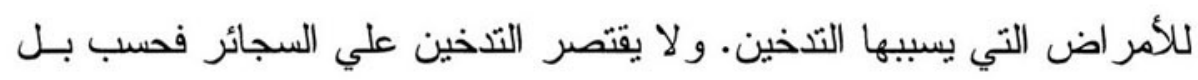

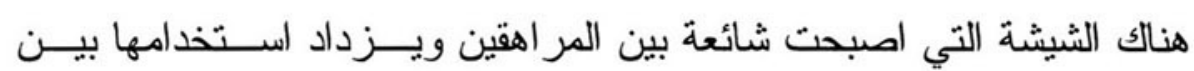

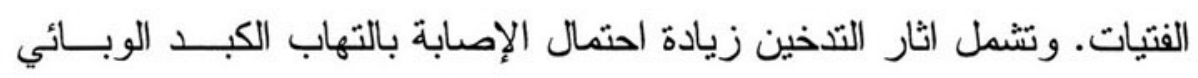
بالفيروس سي و الامر اض المتعلقة باللثة و الاسنان و الرئة.

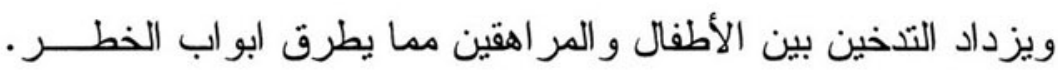

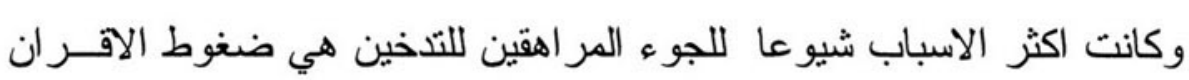

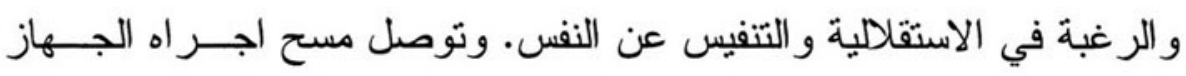

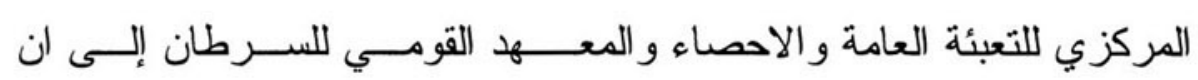

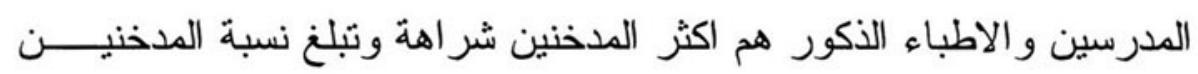

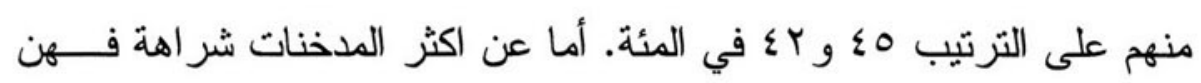
المدرسات أيضا (V في المئة) يتبعهن الطبيبات وطالبات الجامعات (الأهــر ام

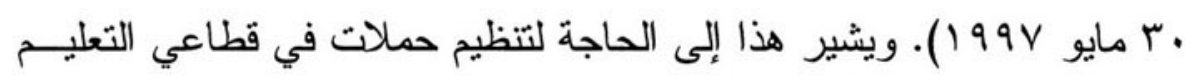
و الصحة حتى يكون الافر اد العاملين فيهما مثالا يحتذى به الثباب. 
في عام 199 199 بدأت وز ارة الصحة و السكان حملة قومية لمكافحــــة

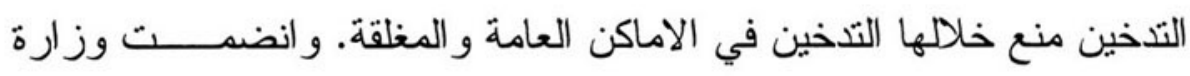

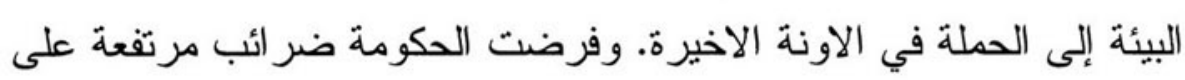

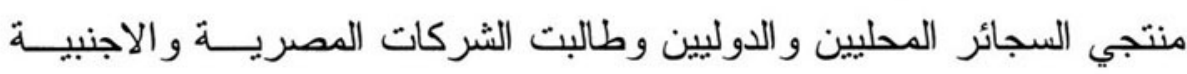

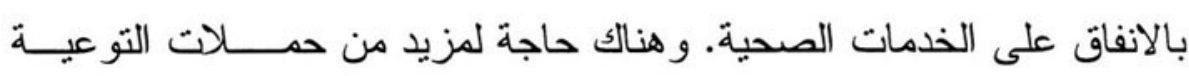
وخاصة في مناطق تجمع المر اهقين كالمدارس و الجامعات و النو ادي ومر اكز

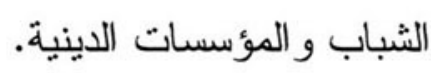

و هناك إدمان اخر خطير هو إدمان المخدرات. ومن بيـــن اسـباب

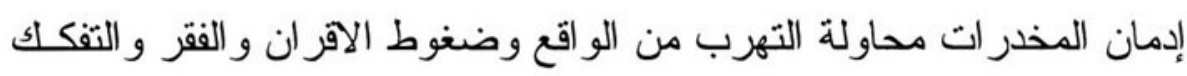

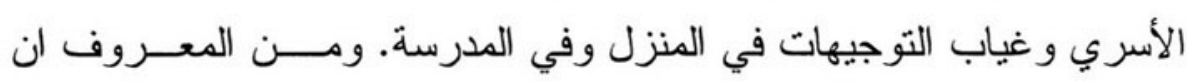

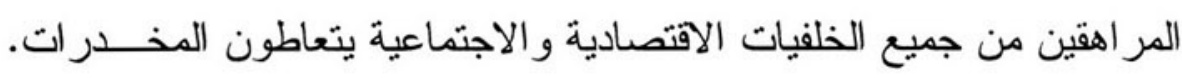

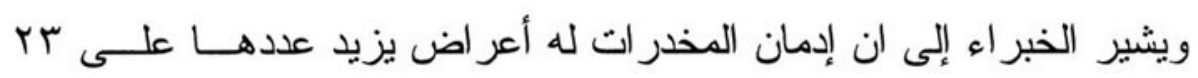

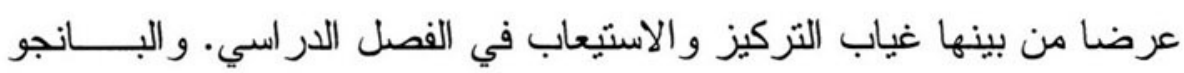

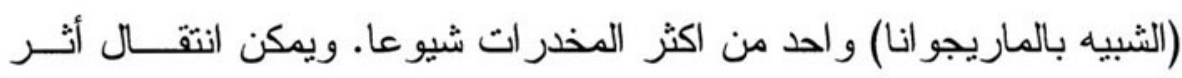

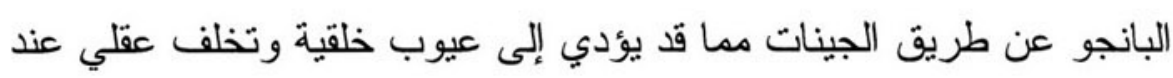

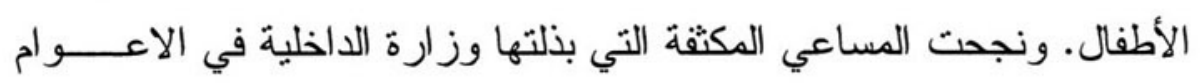
القليلة الماضية في تقليل كمية المخدرات التي تدخل الي البلاد عبر الحــدود.

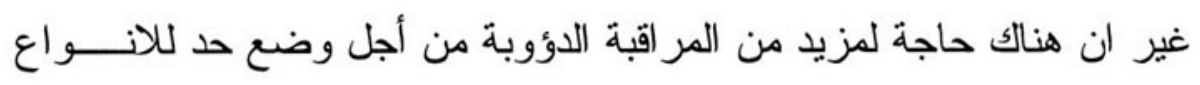

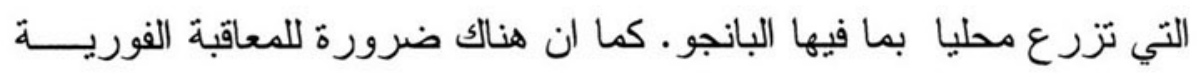

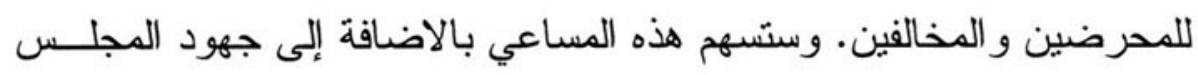

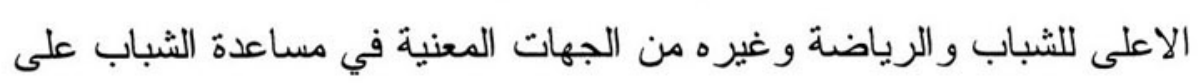

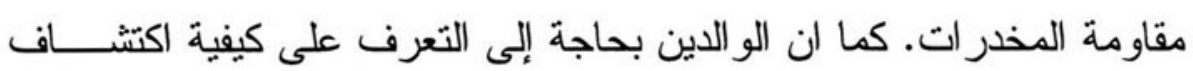




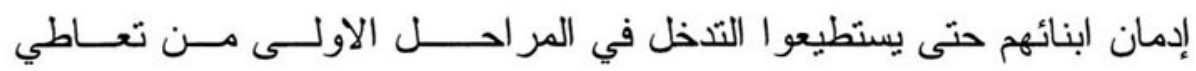

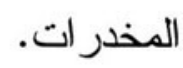

الصحة النفسية والاستقرار العاطفي مع بداية مرحلة البلو غ و المر اهقة تحدث تغير ات هرمونية وبيولوجية

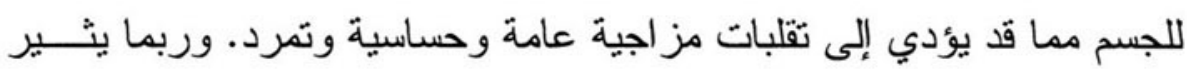

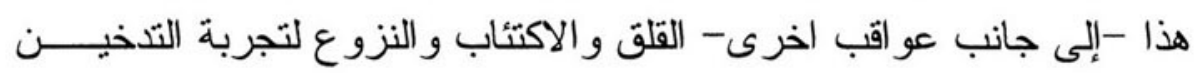
و المخدرات وفي أسوأ الحالات يدفع إلى الانتحار ـ ومن بين الاسباب الرئيسية

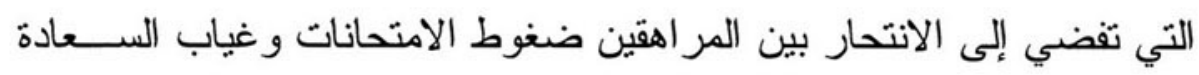

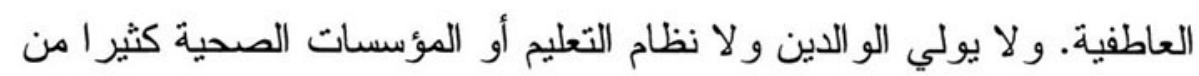

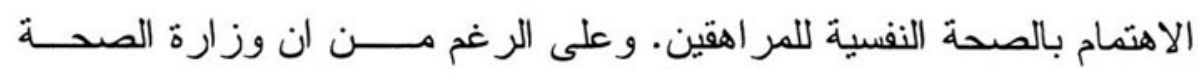

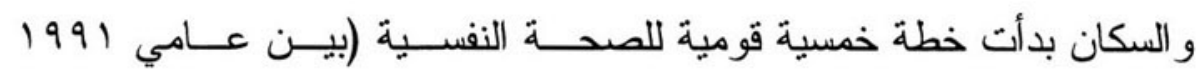

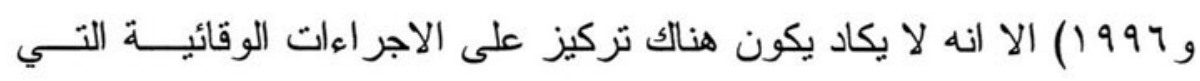

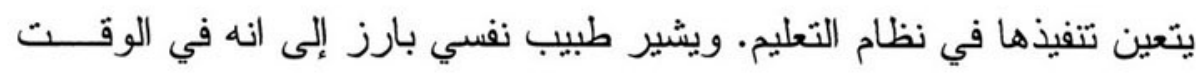

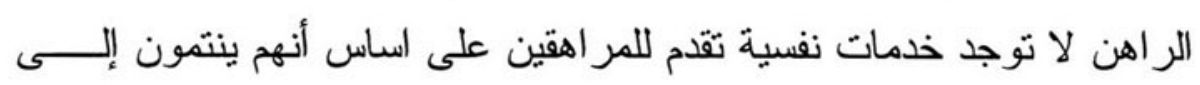

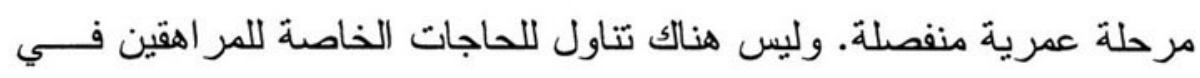

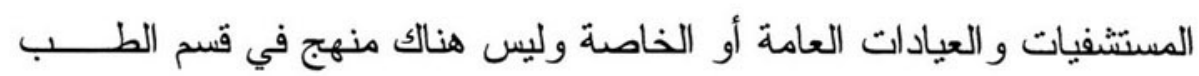

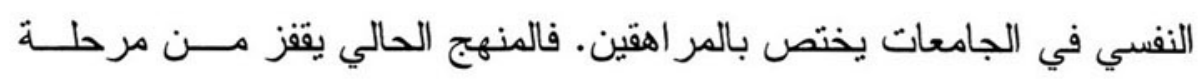

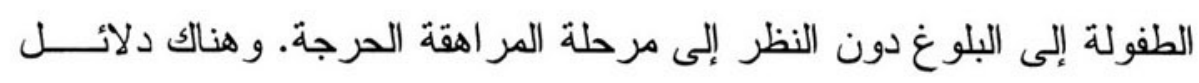

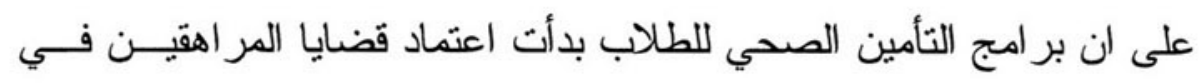

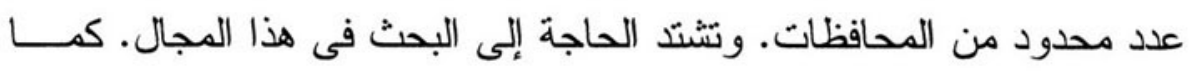

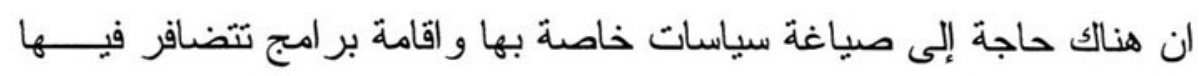
الجهود. 
لا توجد حاليا احصاءات دقيقة عن عدد المعاقين وتوزيعهم العمــري

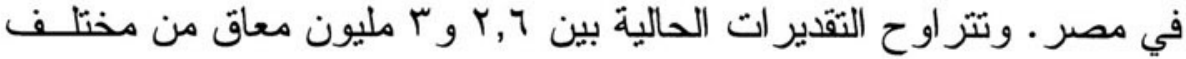
الاعمار في مصر (الوضع الحالي لمسألة الاعاقة في مصر ، أبريل و 99 ( ). ان اهنمام الدولة بالمعاقين كجماعة ذات حاجات خاصة ورد في القـانون وب لسنة 9 19 ـ ثم تلى ذلك تخصيص قسم خاص من قانون الطفل لسنة 1997 لزيادة الر عاية و اعادة تأهيل الأطفال و المر اهقين المعاقين. وبالاضافة الـــي ذلك أظهرت سيدة مصر الاولى سوزان مبارك التز اما متو اصلا تجاه الأطفال المعاقين ولفتت الانظار إلى ان تحسين اوضاعهم ليس التزاما اخلاقيا فحسب بل و اجب جماعي يؤديه المجتمع بأسره.

ويفسر قانون الطفل لسنة 997 السياسة الدولة الحالية تجاه الأطفــال و المر اهقين. ويشمل الاطار المؤسسي المسئول عن الأطفــــال و المر اهقيــن المعاقين وز ار ات الصحة و التعليم و الشؤون الاجتماعيـــــة و القــــى العاملـــة و المجلس الاعلى للشباب و الرياضة و المجلس القومي للامومـــــة و الطفولـــة. ويلزم القانون الدولة بحماية الأطفال وضمان نموهم وصحتهم البدنية و العقلية و النفسية. وتشير المادة VT أن المعاقين يستحقون رعاية خاصة (اجتماعيـــة وصحية ونفسية) نمكنهم من الاندماج فى المجتمع والاعتماد على النفس. كما

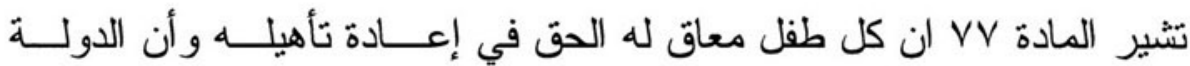
مسئولة عن توفير هذه الخدمات ضمن ميز انية الحكومة المخصصـــــة لــــــا الغرض. وتتص المادة VA على ان بامكان وزارة الشؤون الاجتماعية انشـاء مؤسسات لر عاية المعاقين و امكان ان تتشئ وز ارة التزبية و التعليم مــــدارس وفصو لا خاصة للمعاقين. و هذه المؤسسات ملزمة باصدار شهادات تشير إلى 
المهار ات التي اكتسبها المعاق اما وزارة القوي العاملة فهى مســـئولة عـنـ مساعدة هؤلاء في الحصول على وظائف ملائمة.

ويلزم القانون الشركات التي يبلغ عدد موظفيها ــ موظفا أو أكـــر

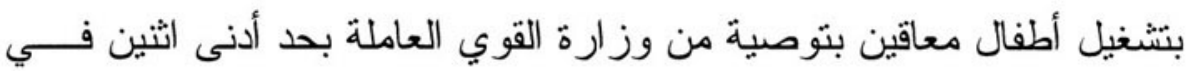

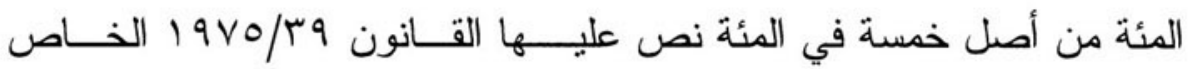
بالمعاقين. وتتص المادة 17 على ان جميع المعدات ووسائل الانثقال الخاصة بالاطفال المعاقين معفاة من الضر ائب و الجمارك.

على الرغم من وجود اطار تشريعي متسع يضمن توفير الاحتياجات الأساسية للأطفال و المر اهقين المعاقين تشير الدائل إلى ان هذه الفئة تظــــلـل

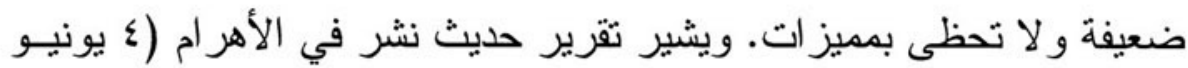

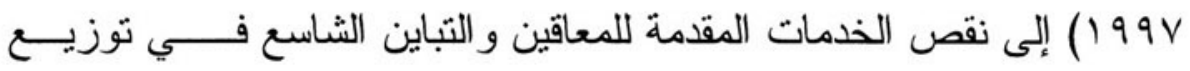

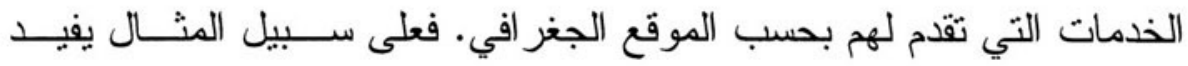

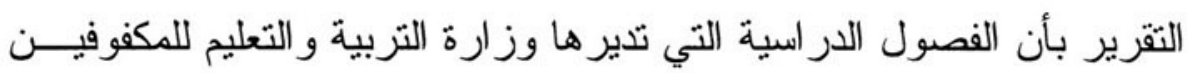

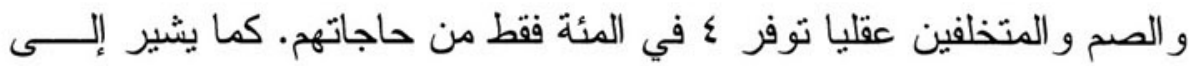

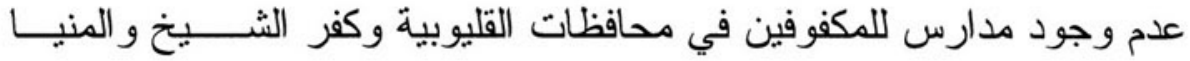
و البحيرة وقنا و أسو ان ومرسى مطروح. كما لا توجد مدارس للمتخلفين عقليا

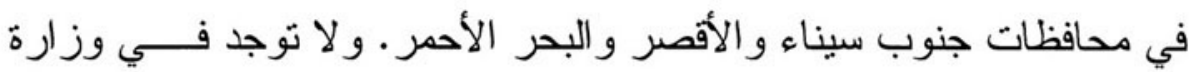

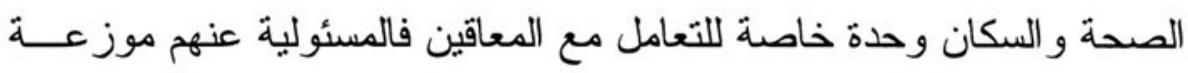

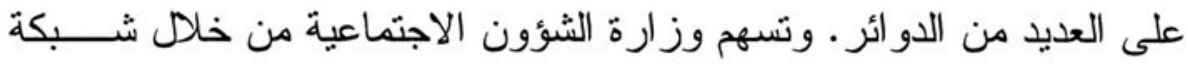

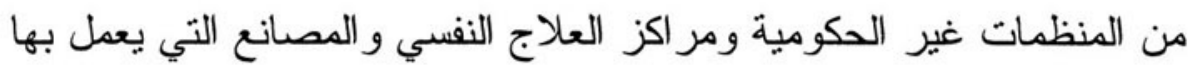
معاقون في التغلب على نقص الموظفين الماهرين في هذا المجال. 
ويحتاج المر اهقون المعاقون إلى مزيد من الجهود الحكومية وغـــير

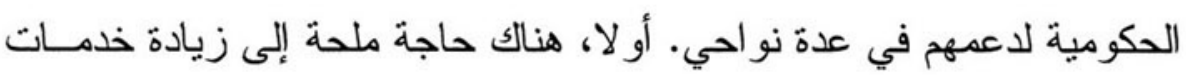

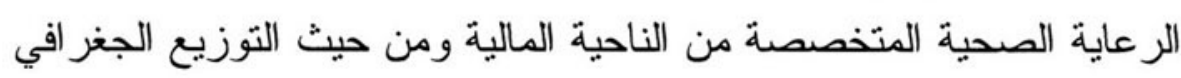

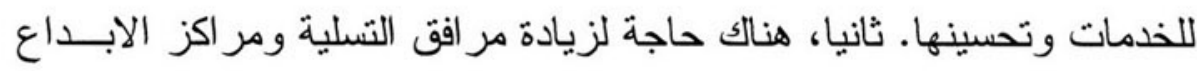

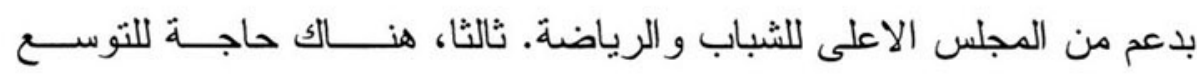

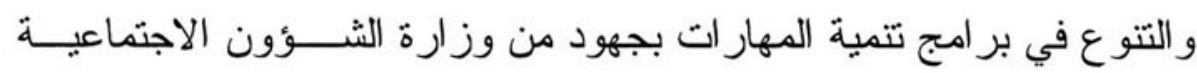
و المنظمات غير الحكومية لضمان حياة منتجه لهذه الفئة. 


\section{الفصل الرابع: الزواج والصحة الإنجابية}

مقدمة

يحظى الزواج في المجتمع المصري بتقدير واحتر ام كبيرين. ويزكي

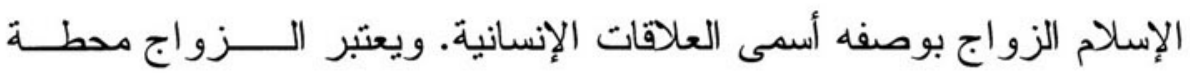

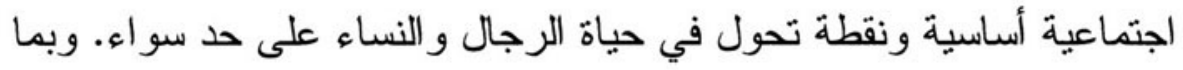

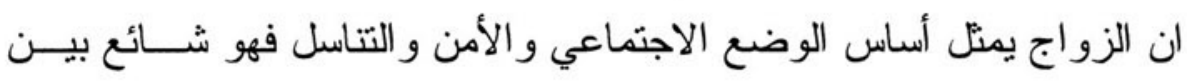

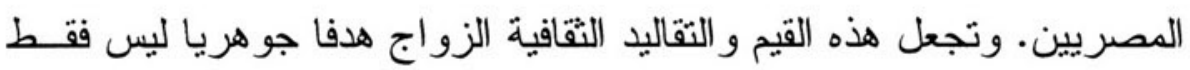
عند الشباب ولكن أيضا عند الأفر اد الآخرين في الأسر المثندة التي تشـــــاهم بشكل كبير في عملية الزواج.

وفي الأعو ام الأخيرة أدى عدد من العو امل الاجتماعيـــــة و الثقافيــة

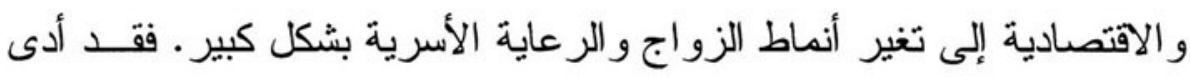

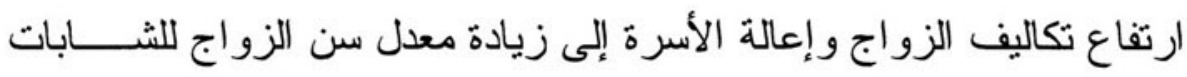

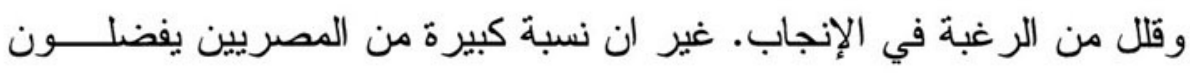

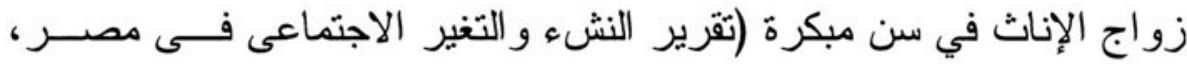

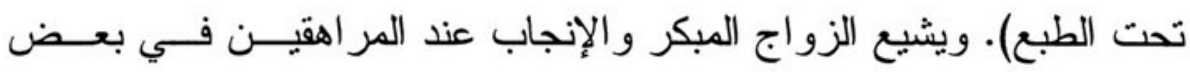

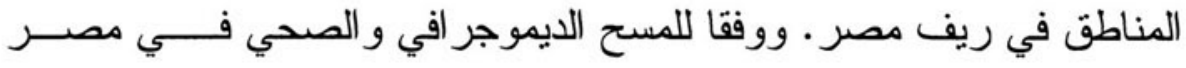

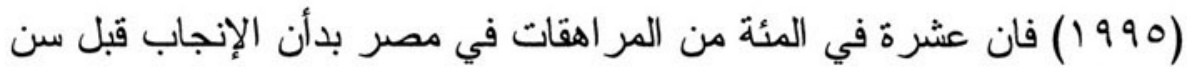

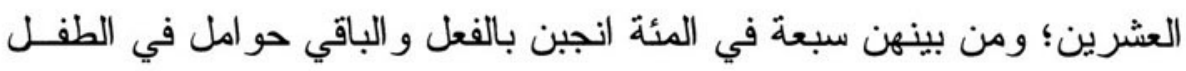

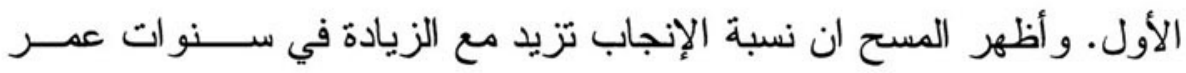

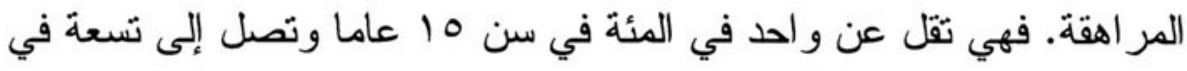

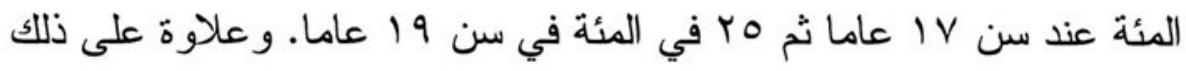
أظهر المسح ان هناك اختلافات كبيرة في المستوى الإنجابي عند المر اهقيـن فئ 
تبعا للتوزيع الجغر افي. فيبلغ معدل الخصوبة عند المر اهقين في الريـف س

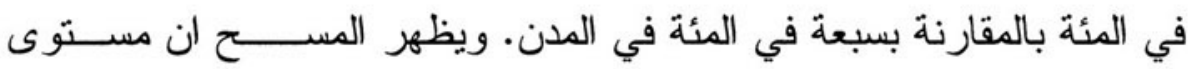

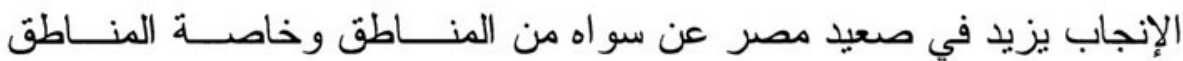
الريفية (1) في المئة) بينما تصل النسبة في الوجه البحري إلى أربعة فـــيـي

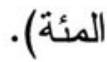

و على الرغم من انخفاض النسبة على مستوى البلاد، فما زال الزواج و الإنجاب المبكر يمثل مشاكل لكثير من المر اهقات اليوم. فهو لا يمنع الإناث

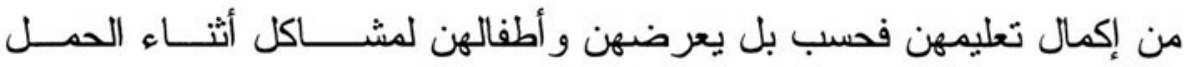
و الو لادة علاوة على خطر الوفاة. ولذلك فان السياســـات المتعلقــة بالســن

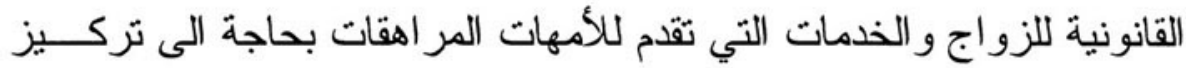

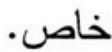

\section{سياسة الدولة الخاصة بالزواج و الأمومة والصحة الإجابية}

تولي سياسة الدولة في مصر اهتماما ووزنا كبير اللزواج. ويســنتد

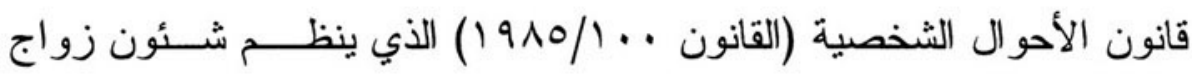
المسلمين على الشريعة الإسلامية.

ويعود قانون الأحوال الشخصية الحالي إلى عام 19 19 عندما أقرت

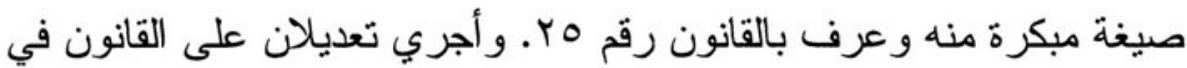

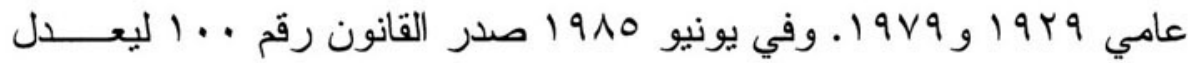
القو انين السابقة وهو القانون المعمول به حاليا. وينظم القانون جميع التفاصيل

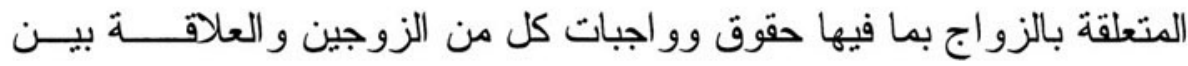


الو الدين و الاو لاد. وبالمثل ينظم القانون إنهاء العلاقة بين الزوجين بــالطلاق

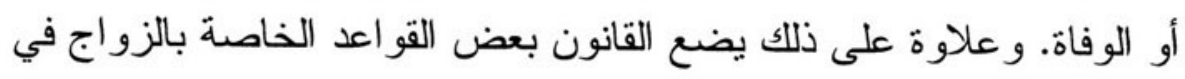

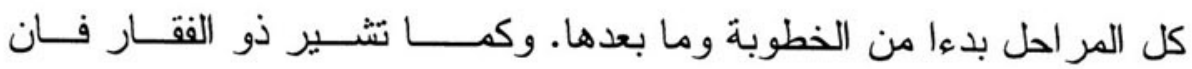

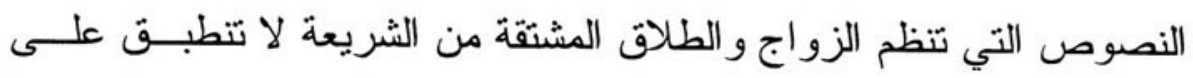
المسيحيين أو غير المسلمين الذين يخضعون لقو اعد أخرى يحددها القـانون.

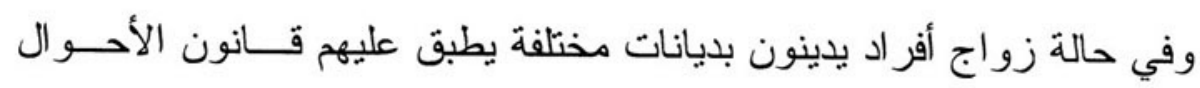
الشخصية (ذو الفقار ، 1990).

ومن بين الثروط الأساسية لصلاحية عقد الزواج مو افقة الزوجيــن.

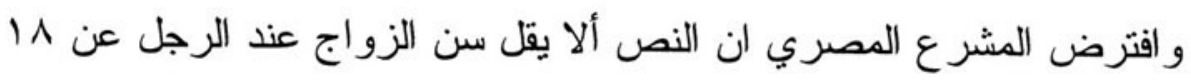

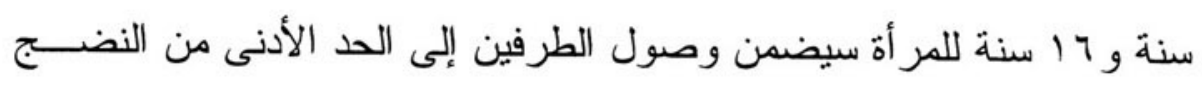
البدني و العاطفي و الذهني و الاستعداد اللازم للزوراج (ذو الفقار ، 990 (1). تتم الزيجات في مصر على بد المأذون الذي يتبع سياســــات وزارة

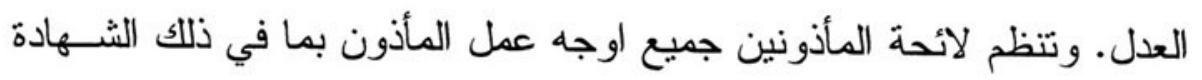

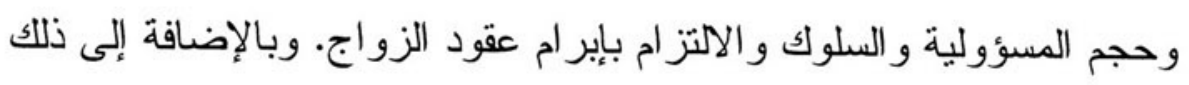

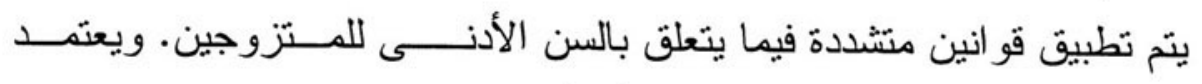

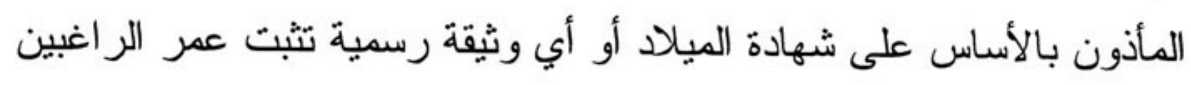

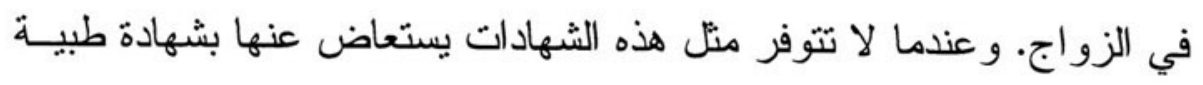

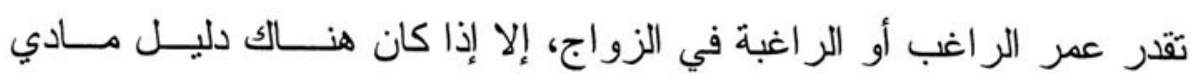

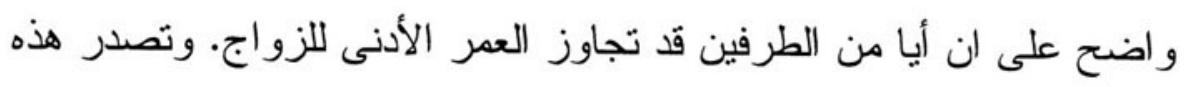

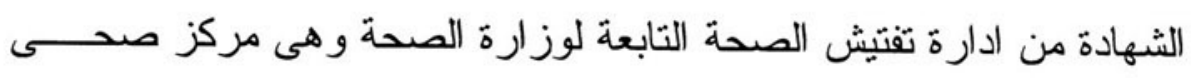

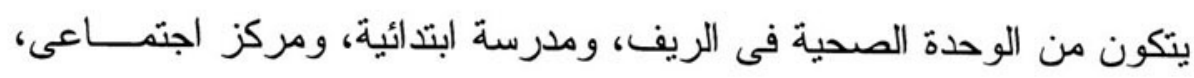

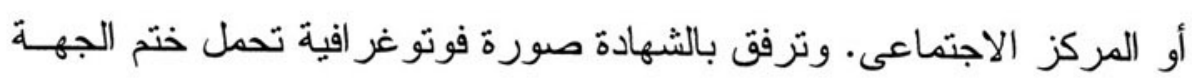


الرسمية، وتوقيع الطبيب او لجنة الأطباء التى نقدر عمـر الر اغبيـنـ فـى

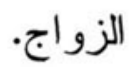

الأمومة

للأكومة مكانة خاصة في مصر ـ ويقدم الدســتور حمايــة للأكومـــة

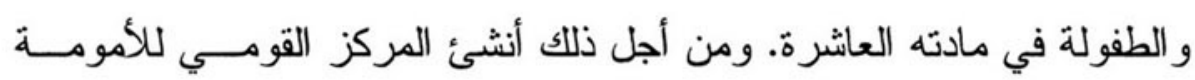

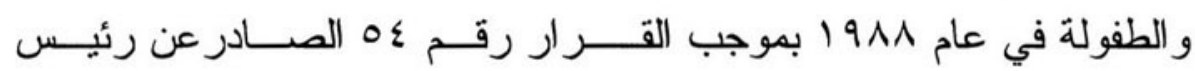
الجمهورية . و وعلاوة على ذلك فإن لدى وز ارة الصحة و السكان شبكة موسعة

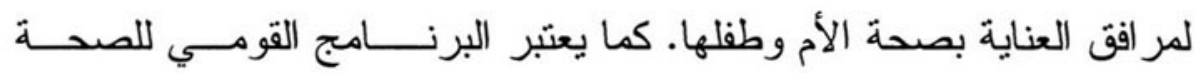

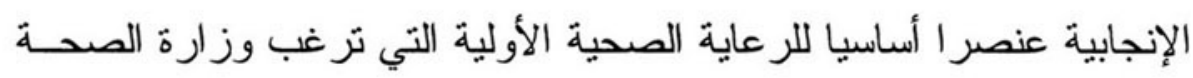

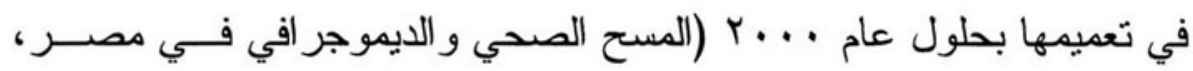

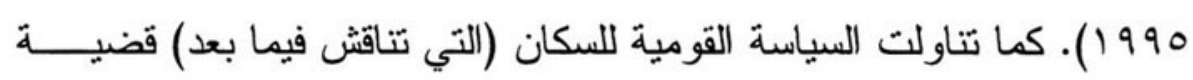

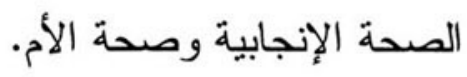

يمنح قانون الطفل لعام 1997 الأمهات العاملات حقوقا خاصة بينـها

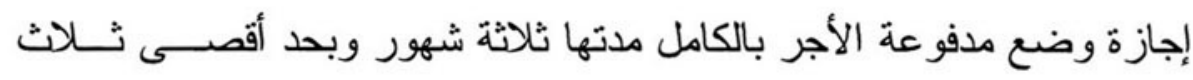

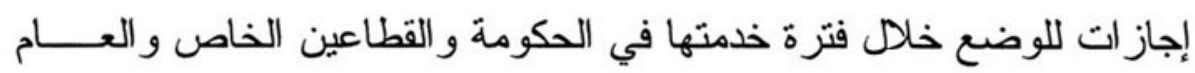

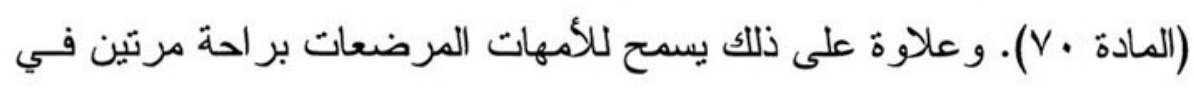

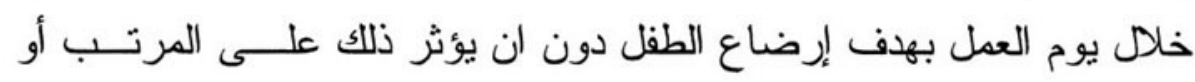

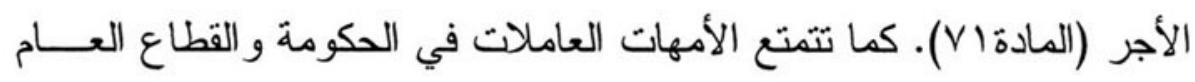

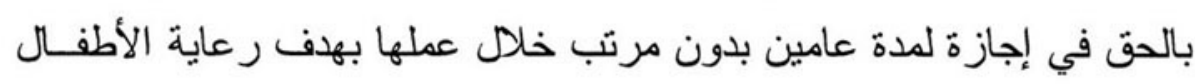

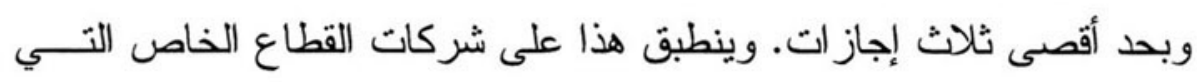

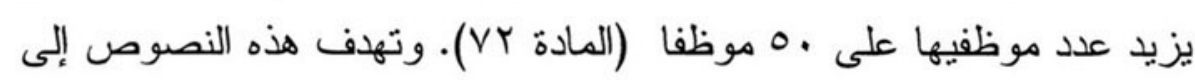

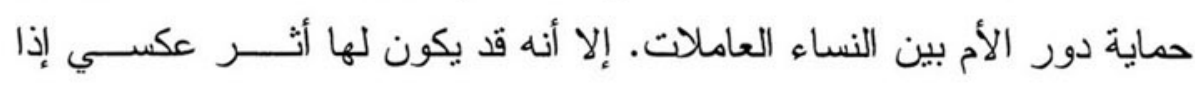




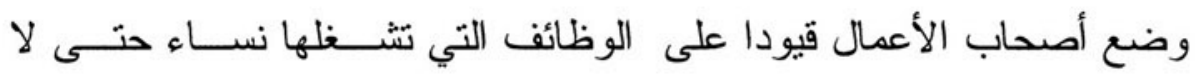
يتكبدو ا كثير ا من الأمو ال. و لا توجد نصوص محددة لحديثات العهد بالأمومة أو الأمهات المر اهقات.

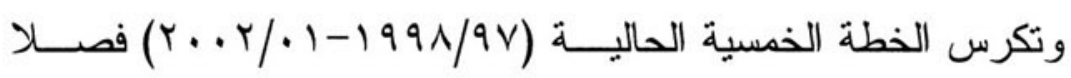

بأكمله لقضايا الأمومة و الطفولة. و هذا مؤشر على الالــــز ام الرفيــع بـــــهـ القضية من جانب الدولة. ولعبت سيدة مصر الأولى دورا جوهريا في وضـع بـع

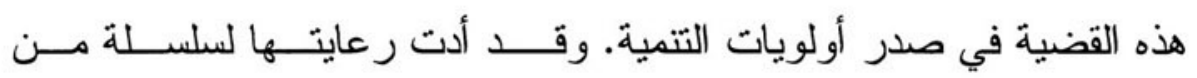

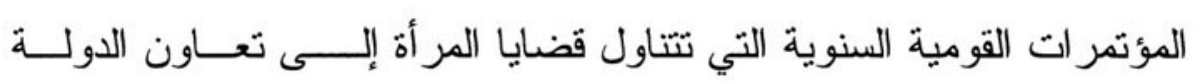
و المنظمات غير الحكومية في التحرك في هذا المجال.

تنظيم الأسرة والصحة الإنجابية

يمثل تتظيم الأسرة و الصحة الإنجابية عنصر ا أساسيا فــي السياســة

السكانية الحالية التي تنفذها وز ارة الصحة و السكان بالتعاون مـــع المجلـس القومي للسكان. وبينما ركزت السياسات السابقة على سبل الحد من نصــــاعد معدلات النمو السكاني وزيادة القبول بفكرة تنظيم الأسرة فان السياسة التــي اعتمدت عقب المؤتمر الدولي للسكان و التتمية تحولت إلى الصحة الإنجابيـة. ووضعت السياسة السكانية نصب أعينها تحقيق الأهداف التالية: - الارثقاء بنو عية تنظيم الأسرة و الانتفاع منها.

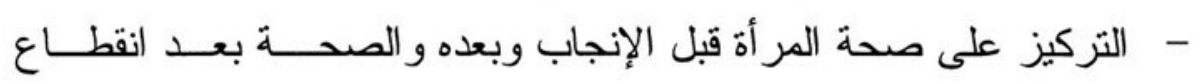
الدورة الشهرية ومساعدة الزوجين على تحقيق أهدافهما الإنجابية. - التستيق و التعاون مع جميع الجهات في مجال الســكان بــــدف تحســين مؤشرات التنمية البشرية في مصر · - العمل نحو اعادة التوزيع الجغر افي للسكان في مصر • 
وفي الوقت الر اهن تثبنى وزارة الصحة و السكان توجها شاملا تجــاه

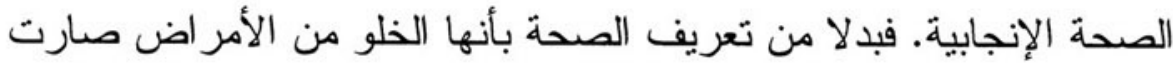

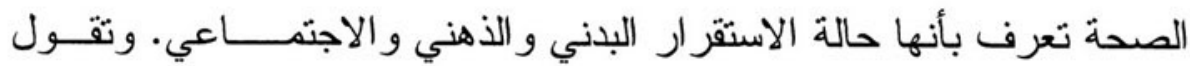
الوزارة ان من حق كل مو اطن الحصول على خدمات ذات نوعيـــــة جيـــة

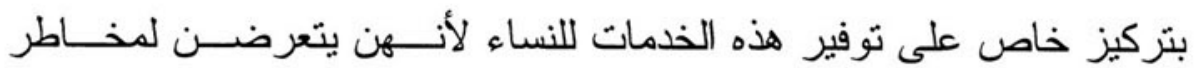

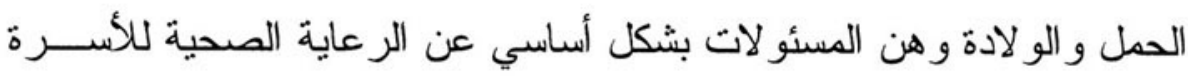

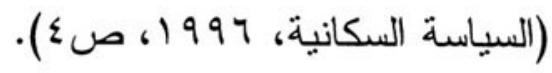

وتتناول السياسة السكانية المر اهقات بصورة مباشرة فقط من خــلد

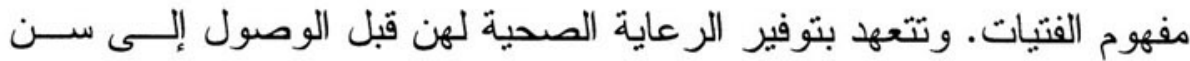

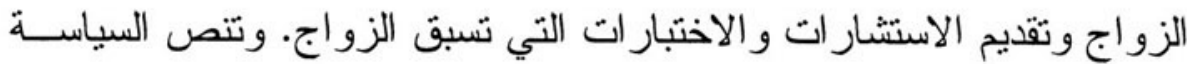
السكانية على التز ام وزارة الصحة و السكان بتوفير خذمات الصحة الإنجابيـة

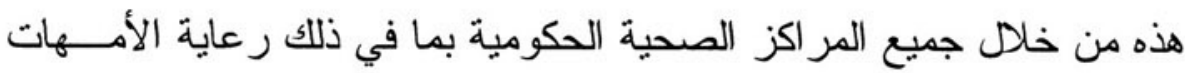

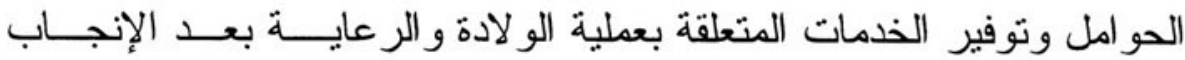

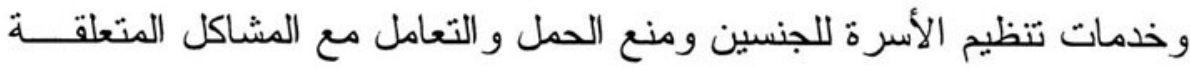
بالإنجاب و العقم. وتدعم الوزارة تقديم هذه الخدمات في المناطق النائية وتلكات

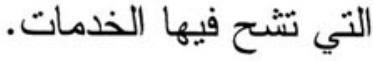

وفيما يتعلق بخدمات تتظيم الأسرة، فــــان سياســـة وز ارة الصحـــة و السكان تركز على الحاجات التي لا تثوفر في مجال تنظيم الأسرة و إدمــــاج خدمات تنظيم الأسرة في خدمات الصحة الإنجابية في إطار صحة الأســرة.

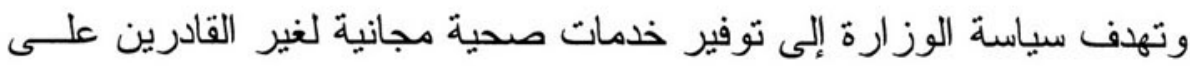

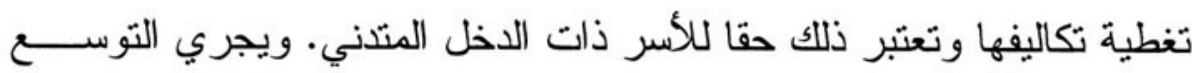


في تحديد طرق الوصول إلى المنتفعين من الخدمات في المناطق النائية مسن

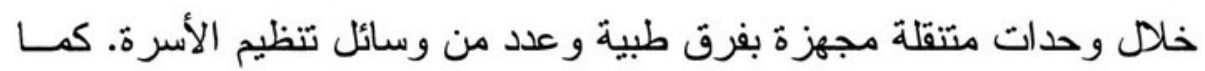

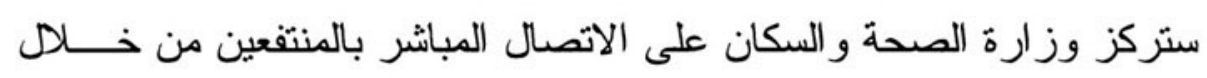

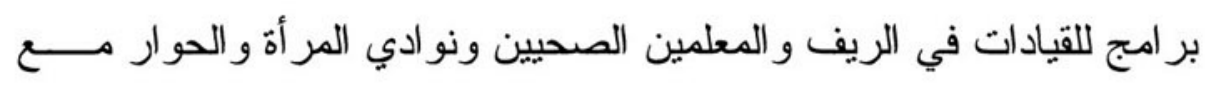
قيادات المجتمعات المحلية و الشخصيات الدينية وغيرها.

التحديات

الصحة الإنجابية و الثقافة الجنسية

تقليديا، كان الو الدان و الأسر مسئولين عن التعليم الضئيل الذي يتلقـاه

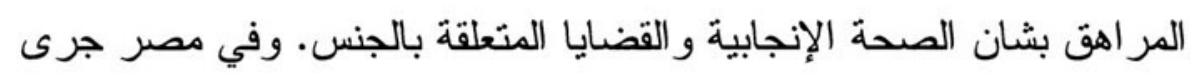

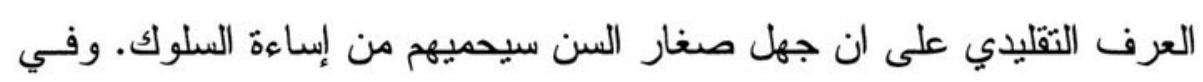

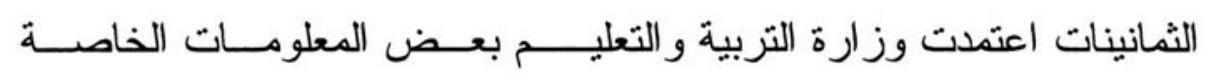
بفسيولوجيا الإنجاب وتنظيم الأسرة في مناهج المدارس الإعدادية و الثانويــة.

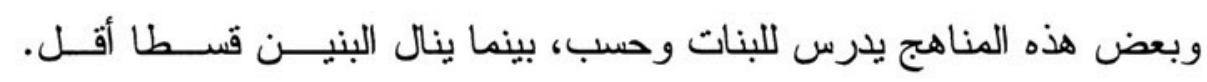

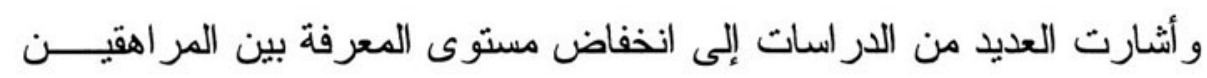

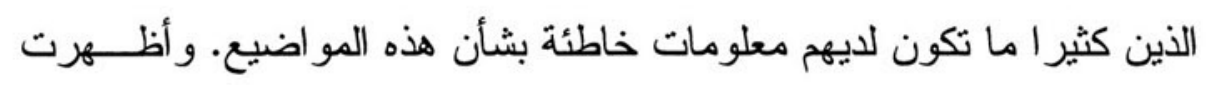

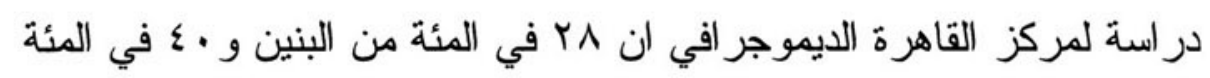

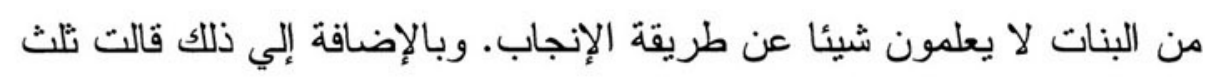

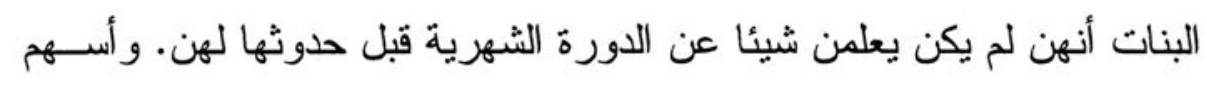

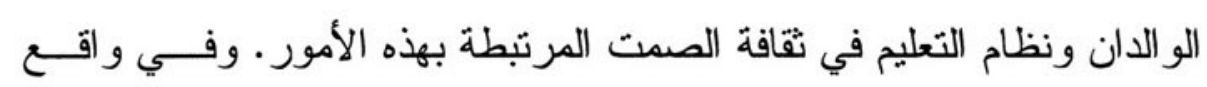
الأمر أفاد المر اهقون في الدراسة التي اجرها مركز القاهرة الديموجر افي ان النافي

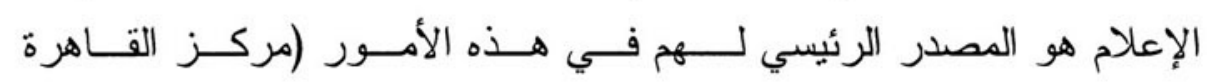

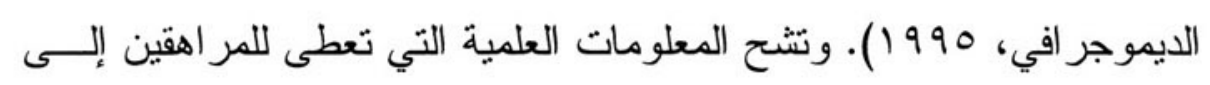


الدرجة التي ينبغي معها الاعتماد على المصادر غير التقليدية للمعلومــــات. ويقول أحد الأطباء النفسيين ان كثير ا من المر اهقين يستخدمون الخط الساخن

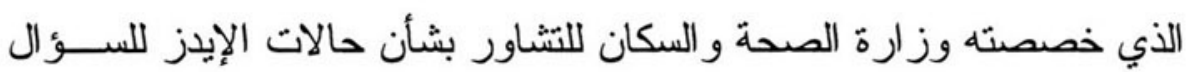

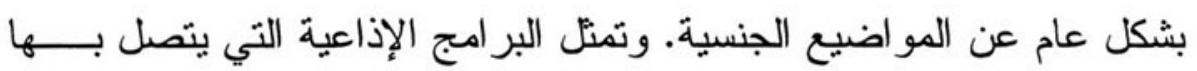

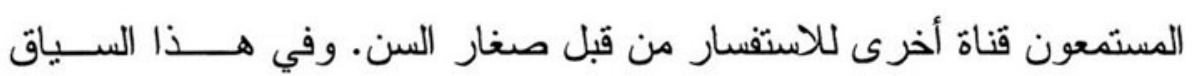

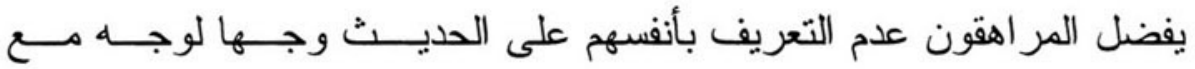

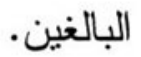

وبينما تقل كمية الأبحاث التي أجريت، تظهر بعض النقــاط الهامــة

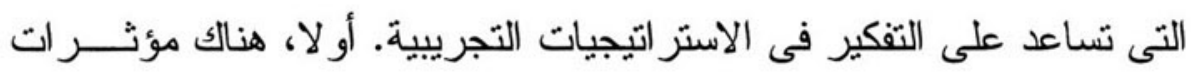

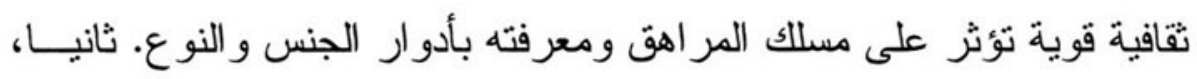

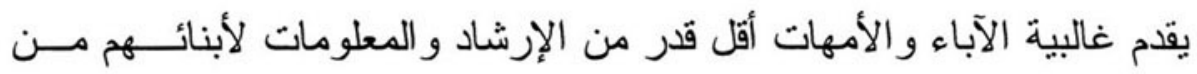

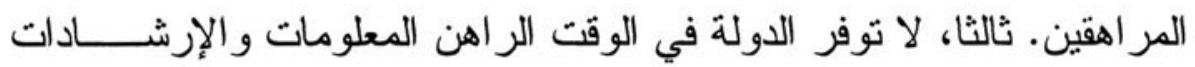

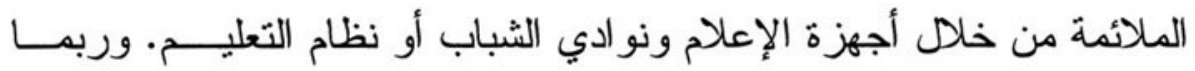
تشمل الطرق الجديدة في معالجة هذا القصور إدخال قضايا الصحة الإنجابيـة

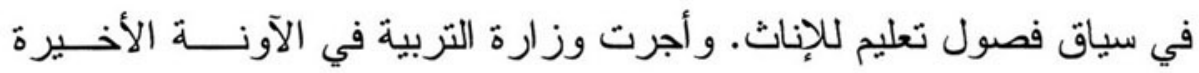

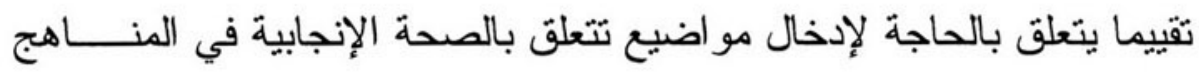

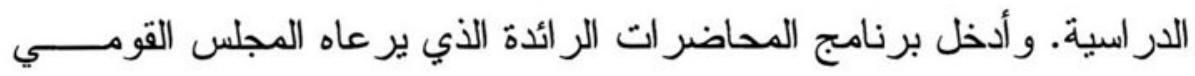

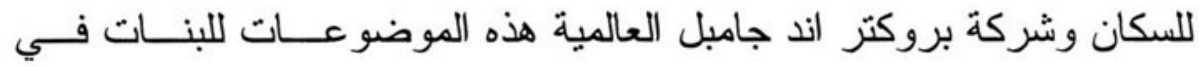
مر احل الدر اسة المتوسطة في مناطق منتقاة. ونتعتزم وزارة التربيـــة إعــداد كادر من المعلمين المتخصصين لتولي هذه الموضوعات عات واستحداث منـــــاهج در اسية لها. ويجري العمل على قيام تعاون في المشرو عات التجريبية الر ائدة

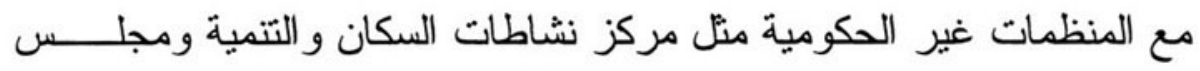

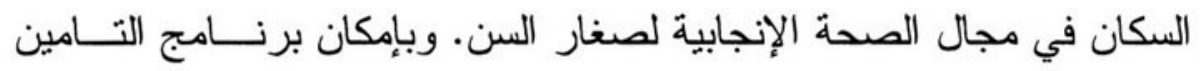


الصدي لطلاب المدارس بالتعاون مع وزارة التربية ان يزيد مــن مســاعي

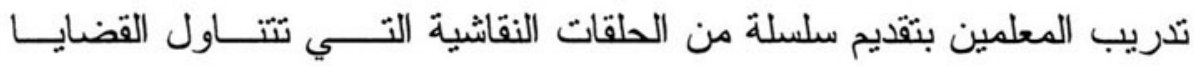

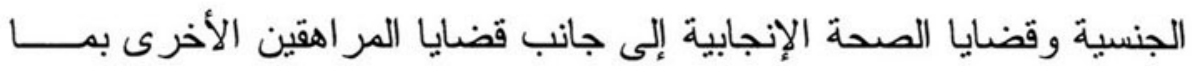
فيها تعاطي المخدر ات و التدخين و التغذية السليمة .

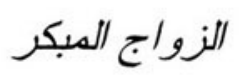

على الرغم من عدم قانونية الزواج المبكر فإن الدولة لا تتعامل معــه

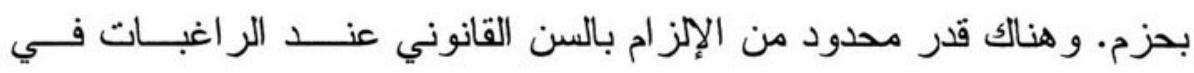

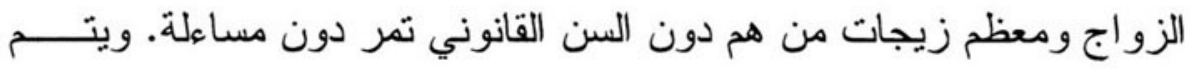

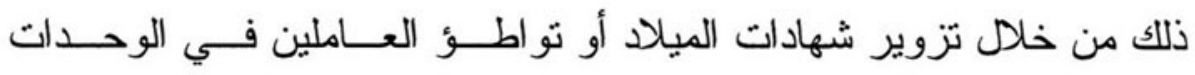

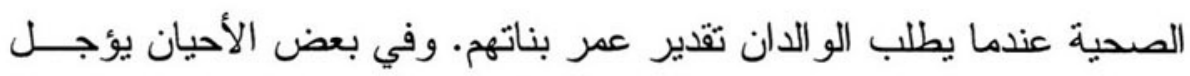

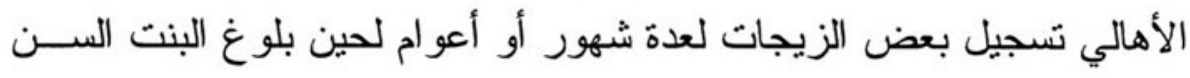

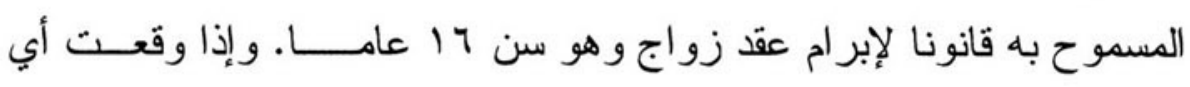

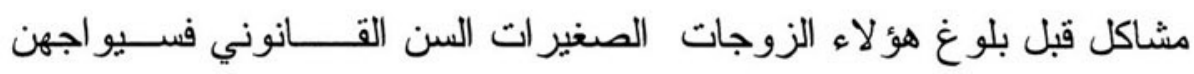

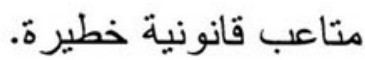

وكما تقول ذو الفقار فان عددا متز ايد من الباحثين و النشطاء يدعـون

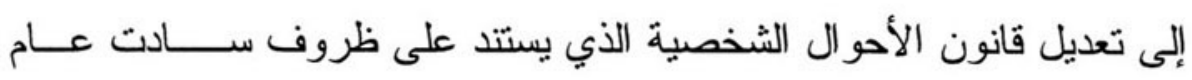

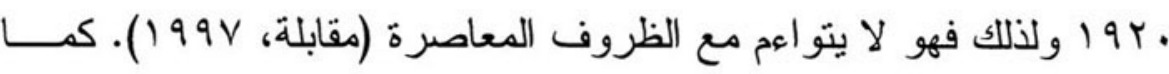
يدعو البعض إلى زيادة سن الزواج إلى 11 1 عاما للإناث و . r عاما للذكور.

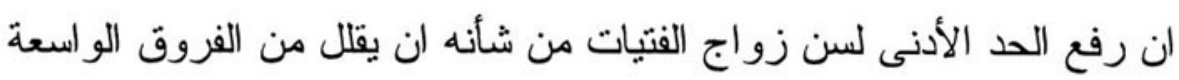

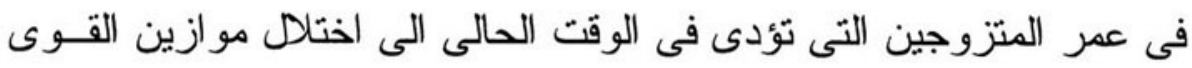

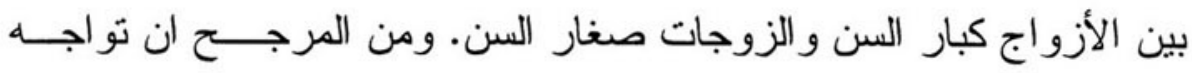


الزوجات المر اهقات احتمال الترمل قبل اكتمال نمو أطفالهن، مما يساهم فـى ازدياد حدة مشكلة الأسر التى تعولها نساء فى مصر .

وبينما ترتبط الزيجات المبكرة مع الأوضاع الاقتصادية والاجتماعية

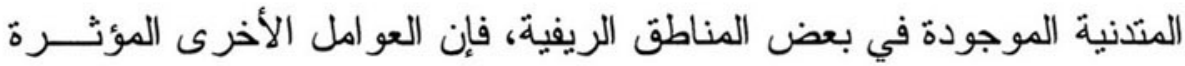
في السن عند الزواج تتعلق بشكل مباشر بالتدابير التي تعتمدها السياســــات.

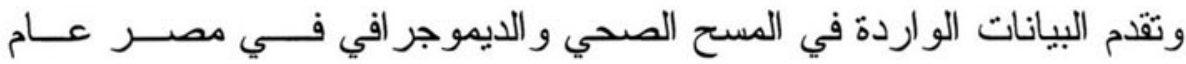

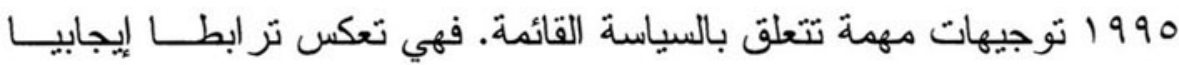

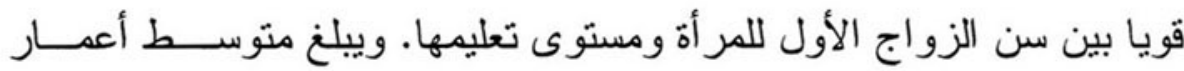

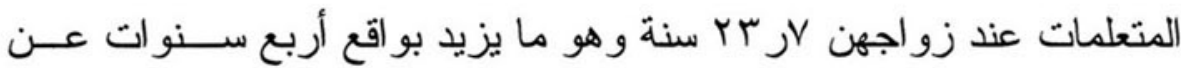

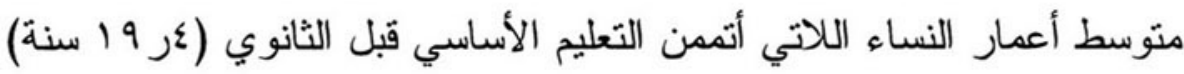

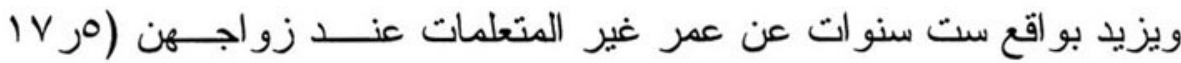
سنة). و الثيء نفسه ينطبق على النساء العاملات فيزيد منوسط أعمار هن عند عند

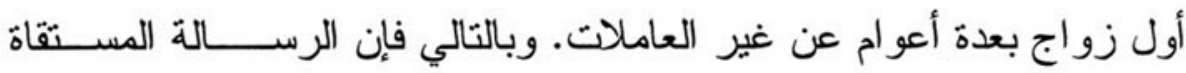

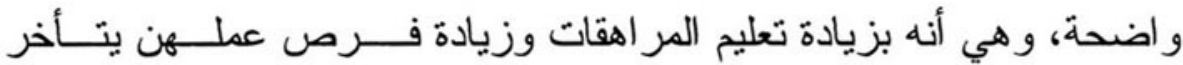

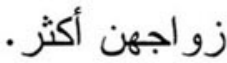

ختان الاناث

بعد ان سلمت الدولة بعو اقب ختان الاناث حــــاولت معالجــة هــــه

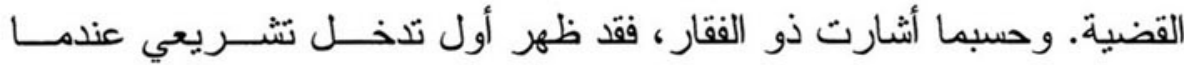
أصدرت وزارة الصحة قرار ا في 1909 بحظر ختان الاناث في الوحســدات

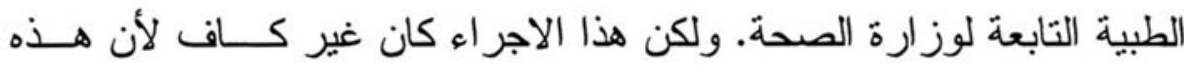

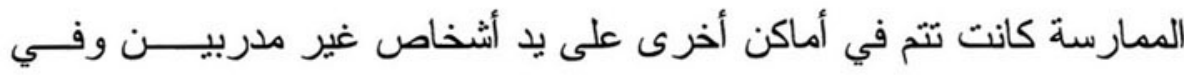
ظروف غير صحية. وفي محاولة للحد من ختان الاناث على يد ممارســــين 
غير مرخص لهم بالعمل في هذا المجال أصدرت وزارة الصحة مرسوما في اعقاب المؤتمر الدولي للسكان و التتمية بالسماح بممارسة الختان في الوحدات

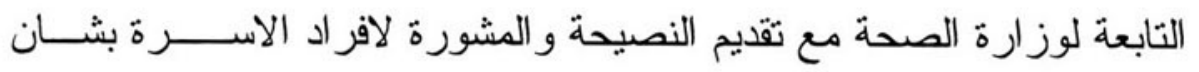

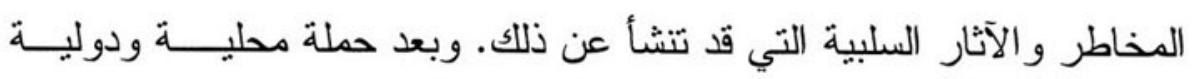

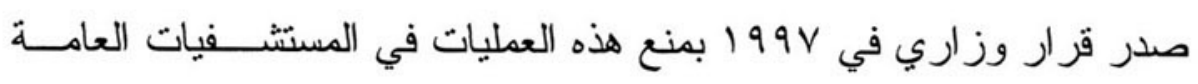

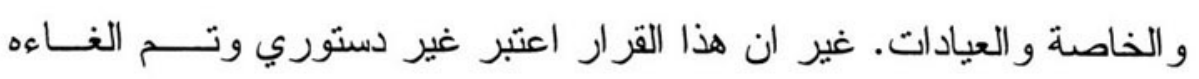

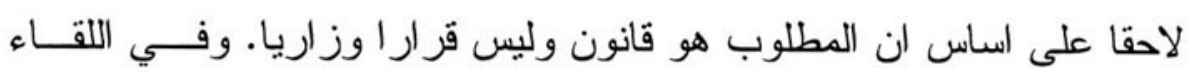

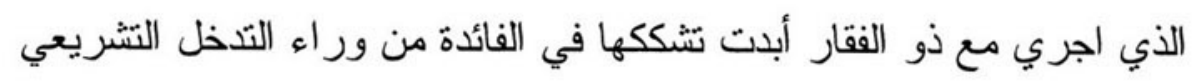

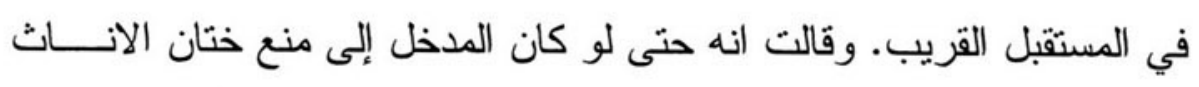

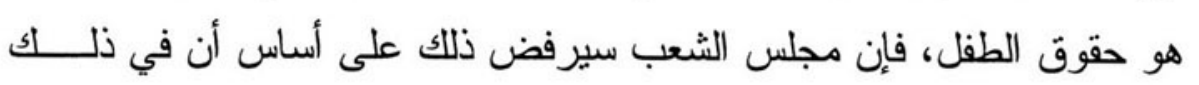
انتهاك للحقوق الاساسية للأسرة.

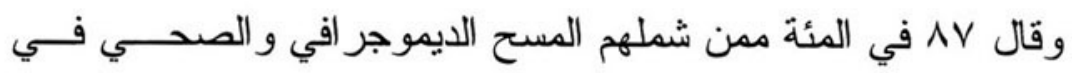

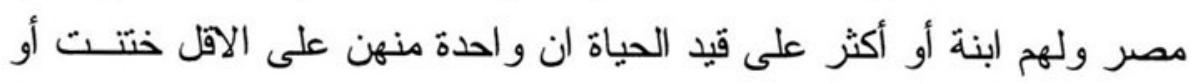

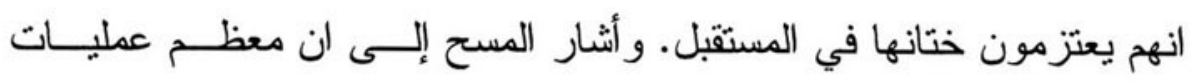

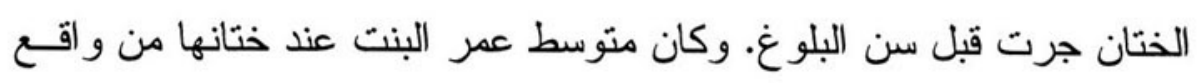

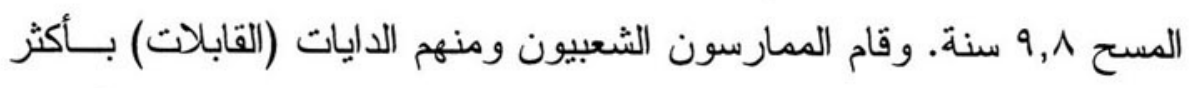

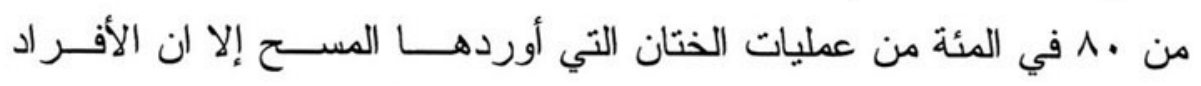

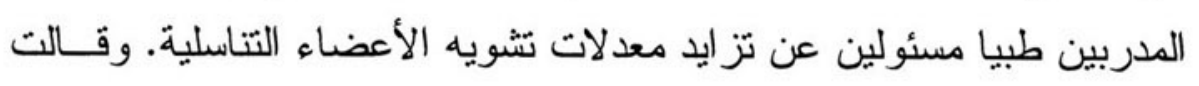

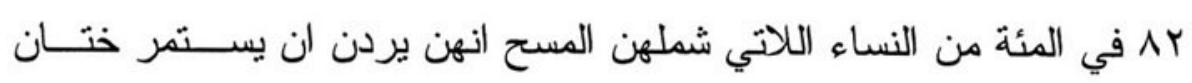
الإناث.

كما وجد المسح ان r N في المئة من النساء اللاتي يعــارضن هـــهـ

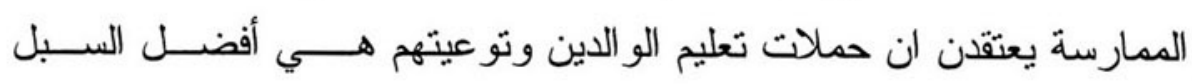




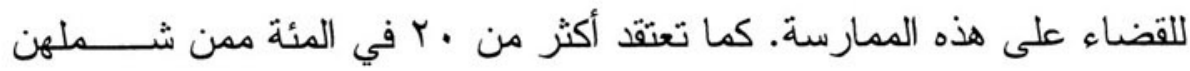

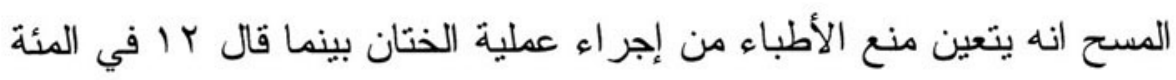

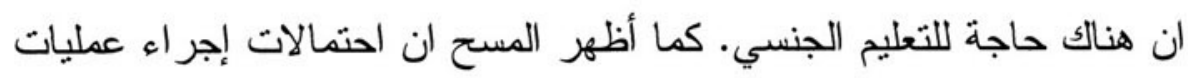

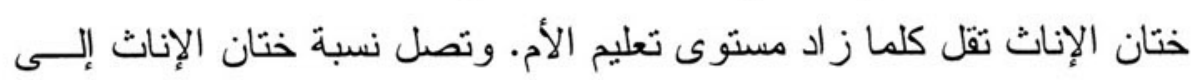

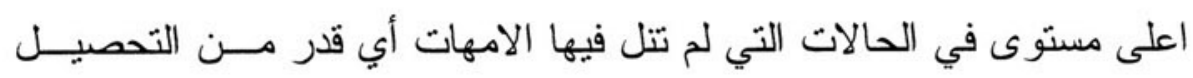

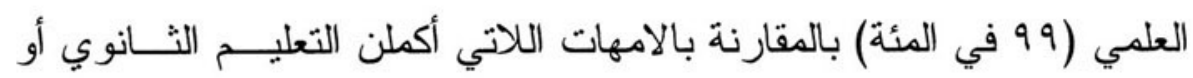

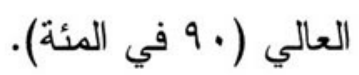

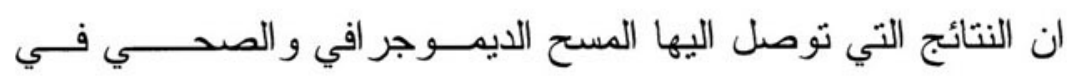

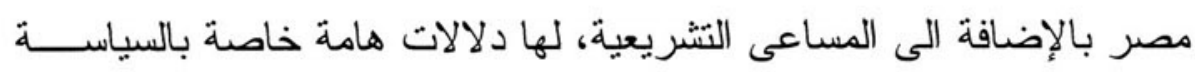

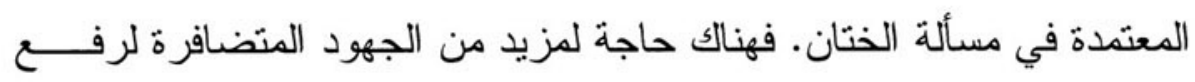
الوعي وتعليم الناس بشان الخر افات المحيطة بممارسة ختان الإناث و الآثـار

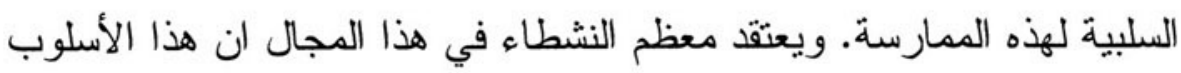

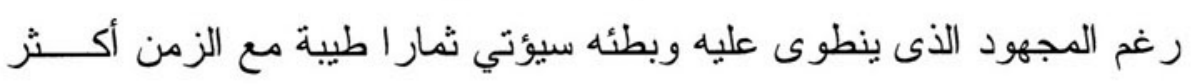

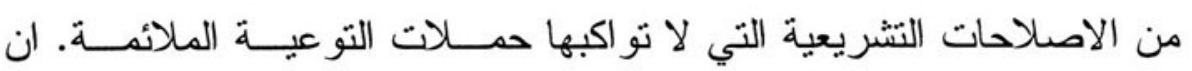
القضاء على ختان الاناث سيتطلب الكثير من الوقت، ومع ذلك فإن التعسـاون

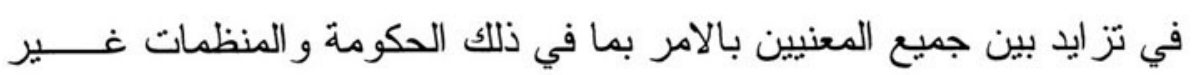

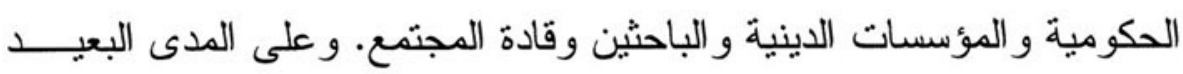
فإن تحسين فرص تعليم الإناث قد يقلل إلى حد بعيد من انتشار هذه الظاهرة.

خصوبة المراهقات ووفبات الأمهات

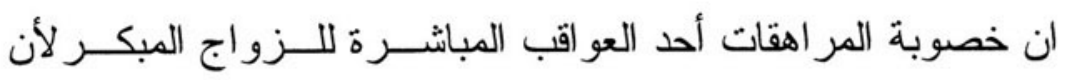

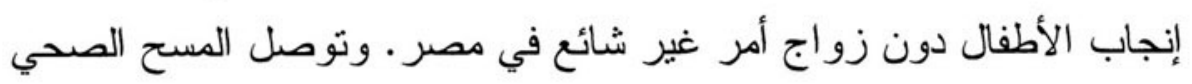

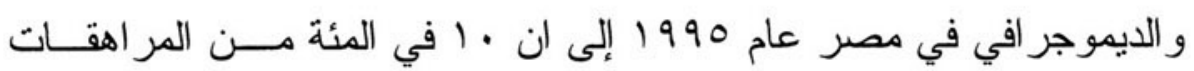


(بين 10 و 19 عاما) قد ولدن أو حملن لأول مرة وان 11 في المئــــة مــن

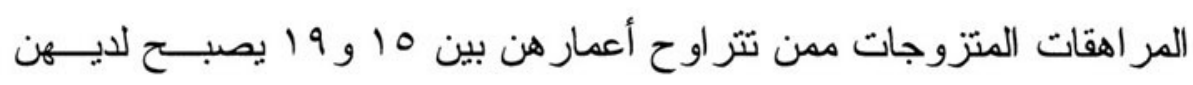

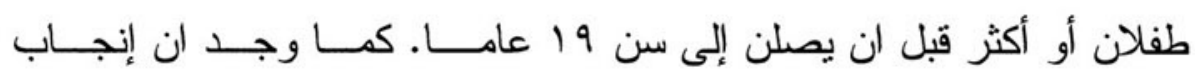

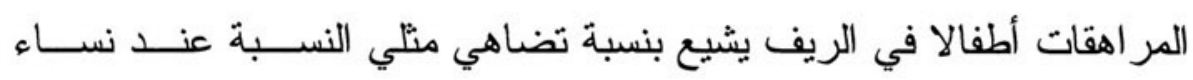

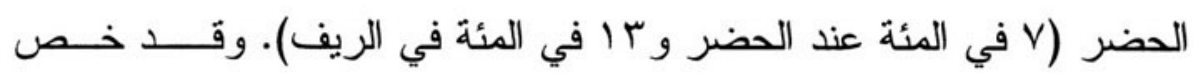

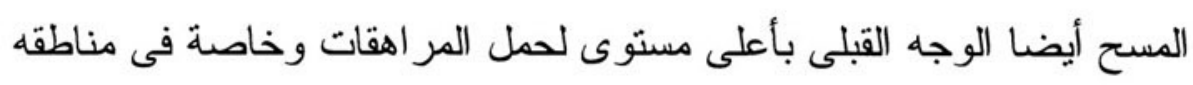
الريفية (1) 1 (\%).

ان خصوبة المر اهقات قضية مهمة لان لها مضاعفات صحية علـى

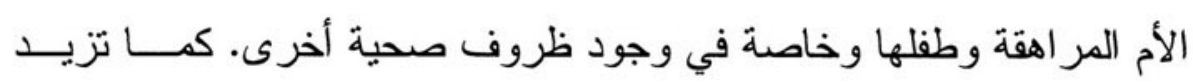

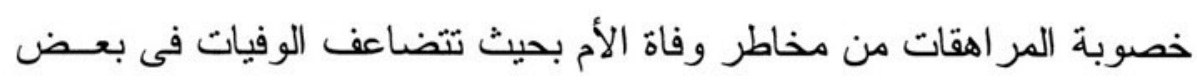

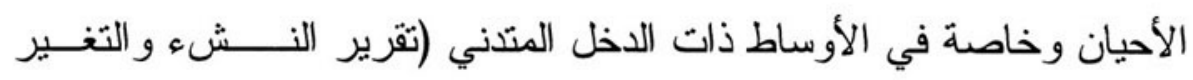

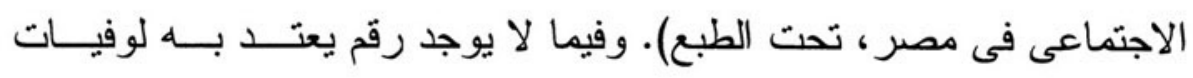

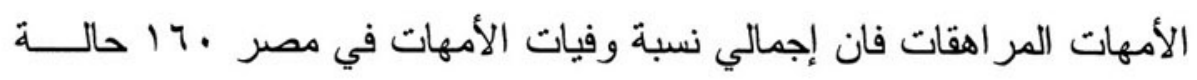

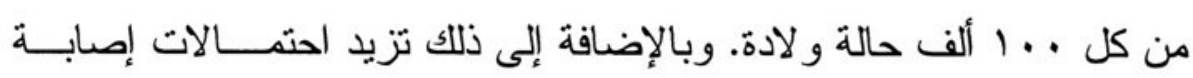

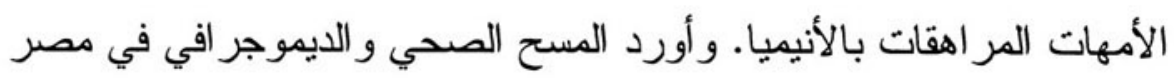

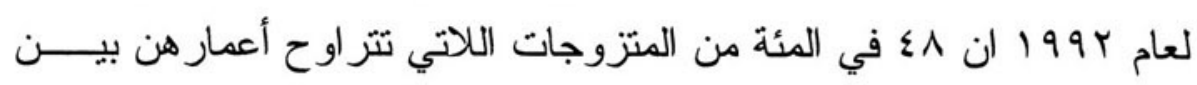

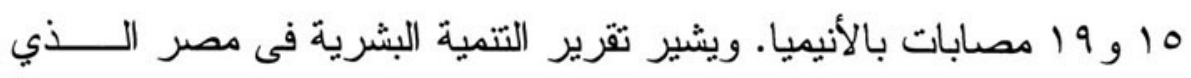

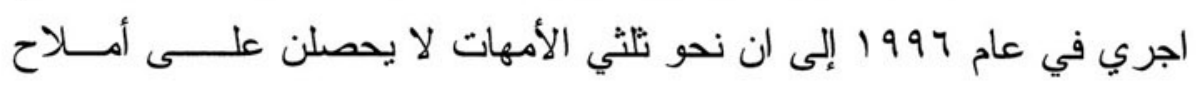
الحديد الكافية لتلبية .9 في المئة من حاجاتهن اليومية.

كما يكون أبناء الأم المر اهقة عرضة للأكر اض بصورة مســـتمرة.

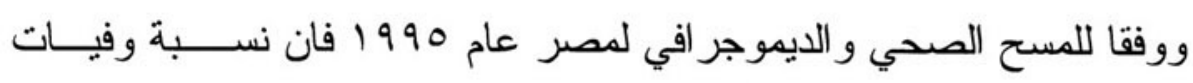

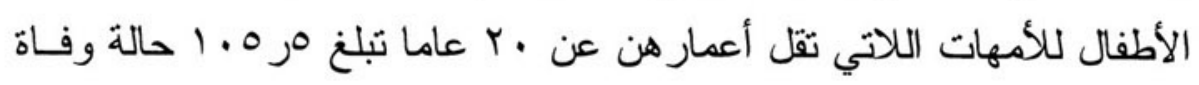


من كل ألف حالة و لادة بالمقارنة بنسبة ؟7 حالة وفاة من كل ألف حالة و لادة

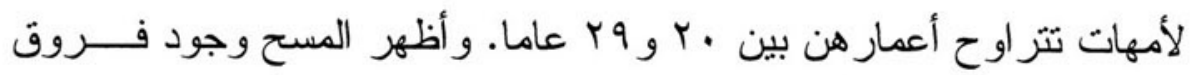

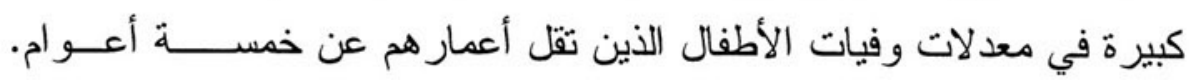

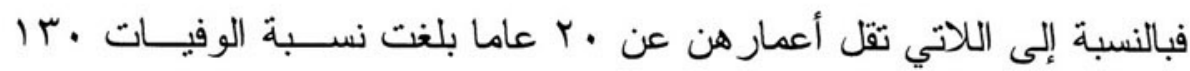

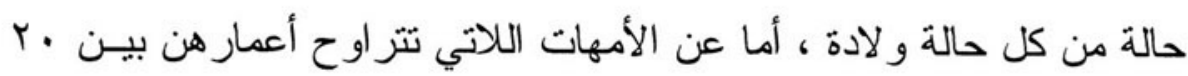

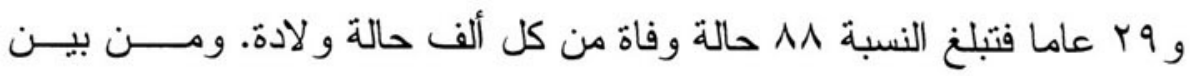

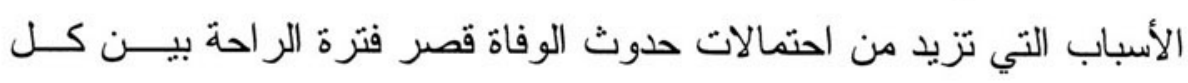

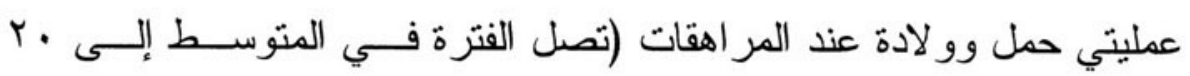

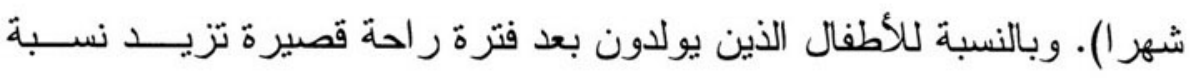

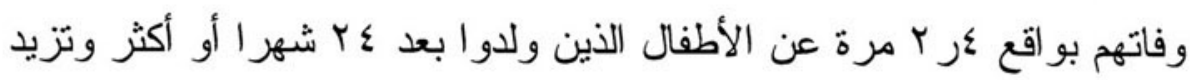

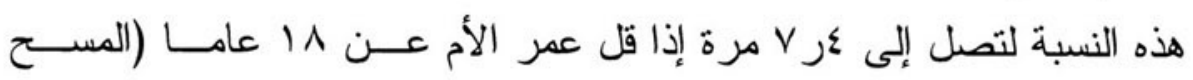

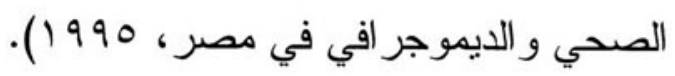
إن الرعاية التي تلقاها المر اهقة خلال الحمل و الو لادة قد تقلــلـ مــن

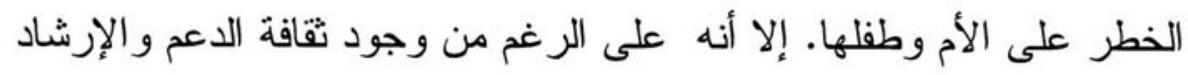

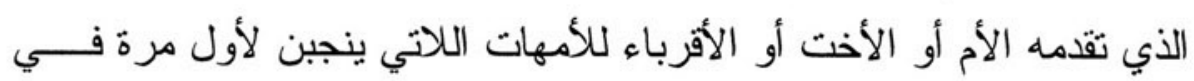

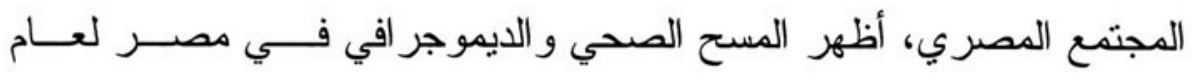

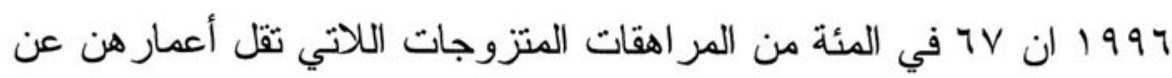

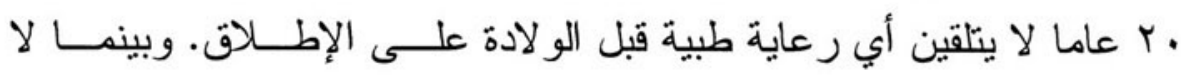

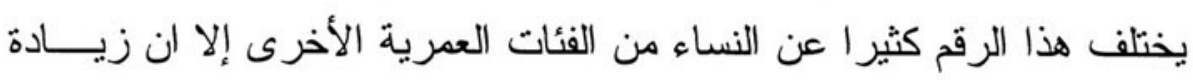

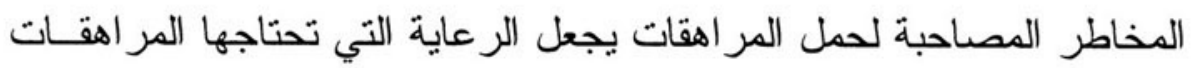

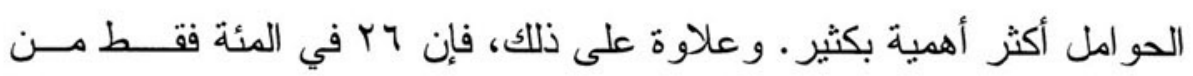

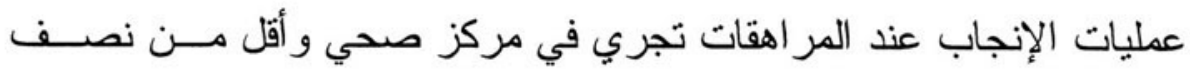
عمليات و لادة المر اهقات حضر ها طبيب أو ممرضة مدربة أو داية (قابلــة). 
وفي محاولة للتصدي لهذه الظو اهر يمنع قانون الطفل لعام 1997 حضـــور

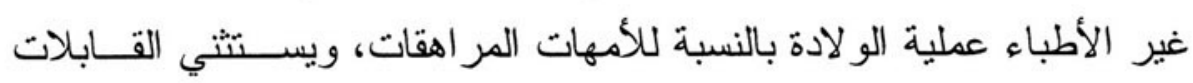
المدربات أو مساعدات القابلات المسجلات (المادة ^).

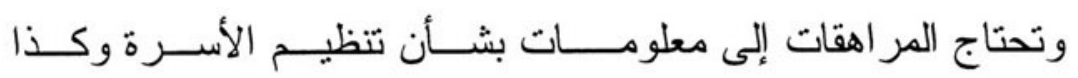

الاستشار ات التي تعنى بهن تحديدا. وتوصل المسح الصحي و الديموجر افــي لهي

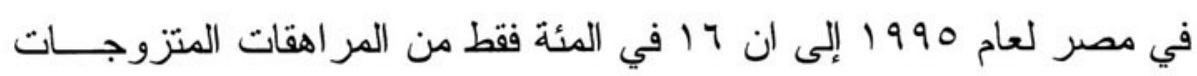

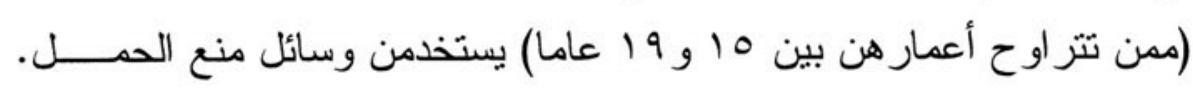

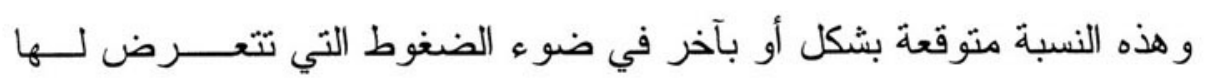

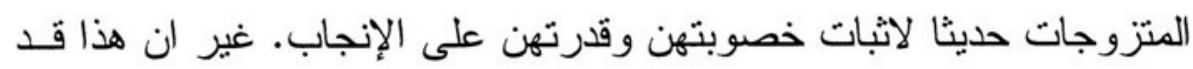

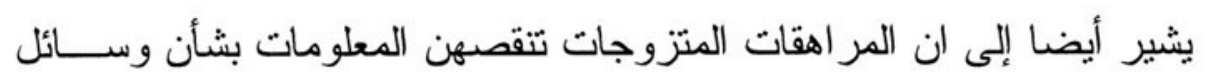

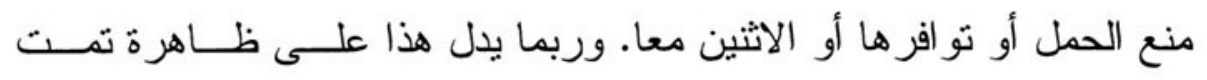

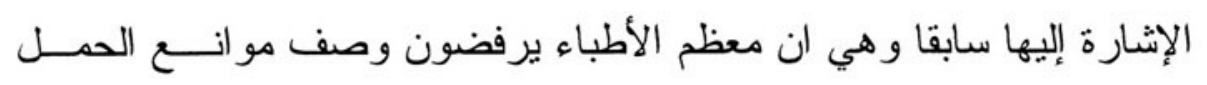

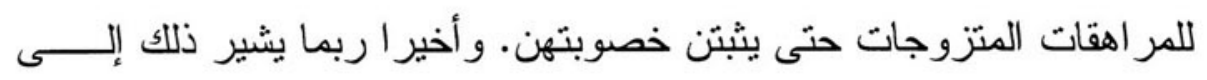

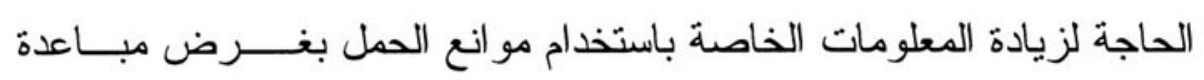

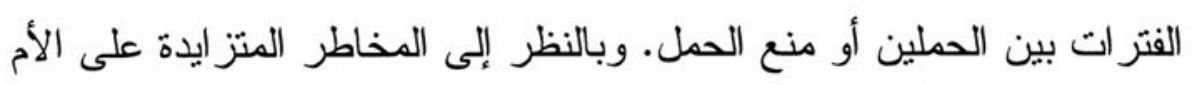
وطفلها الناجمة عن قصر فترة الر احة بين الحملين، تظهر هذه الفجوة المهئة

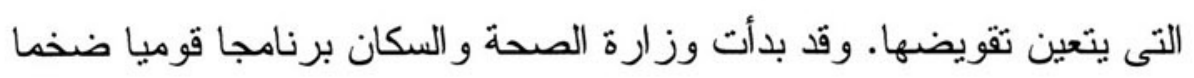
ينعرض لقضية الأمومة الآمنة.

هذه النتائج تعطي مؤشر ات مهمــة لصـــانعي السياســات ومنفـــي

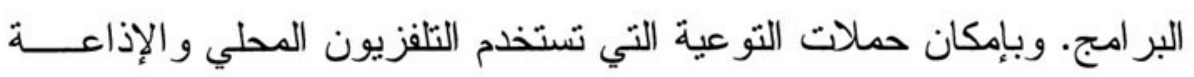

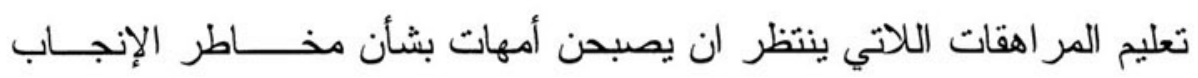

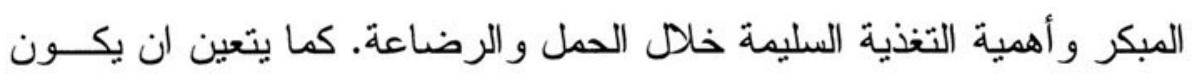




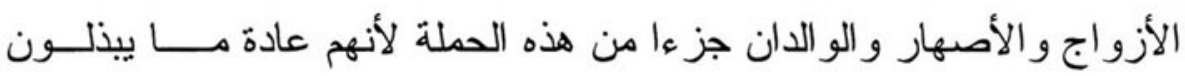

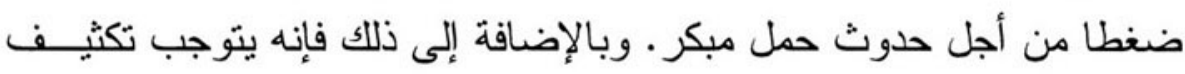
جهود الدولة لتوفير خدمات تنظيم الأسرة ور عاية الأمومة في المناطق النائية

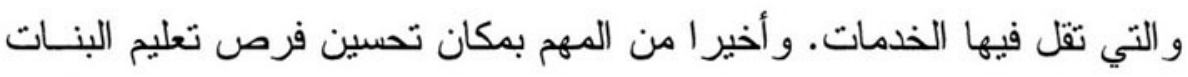

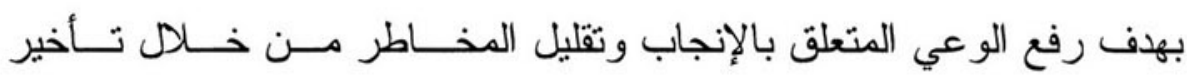
الزواج. 
الفصل الخامس:عمل المر اهقين وتوظيفهم

\section{مقدمة}

كما هو الحال في العديد من الدول النامية يطرح عمـــل المر اهقيـنـن

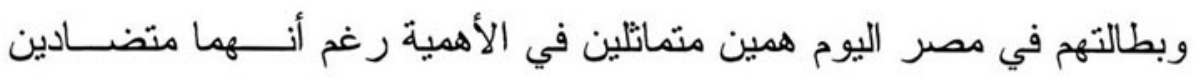

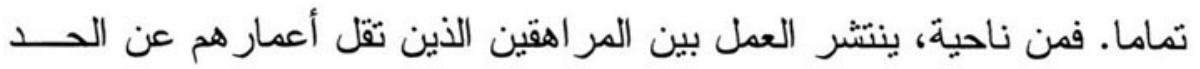

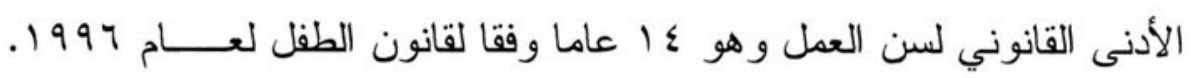

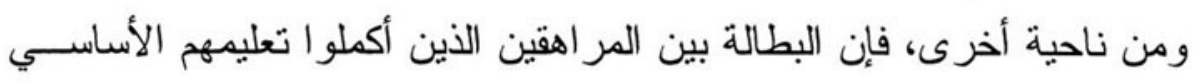

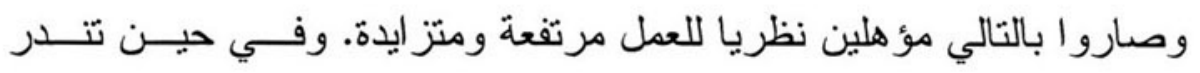

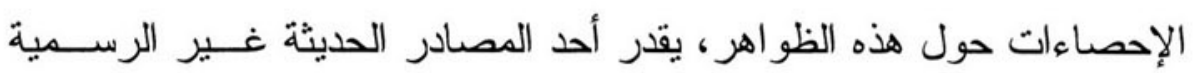

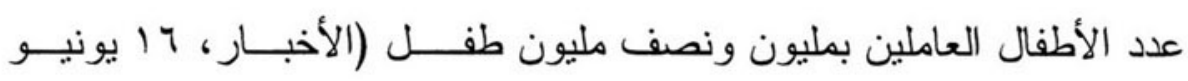

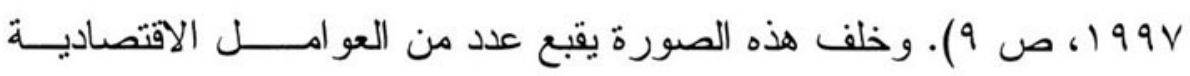

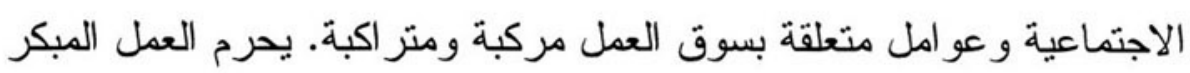

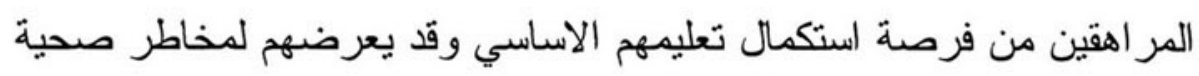

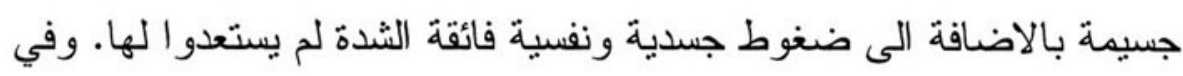

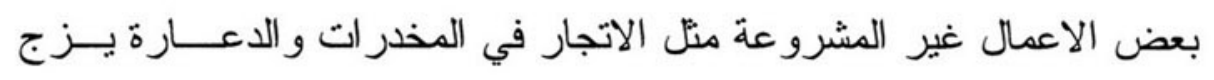

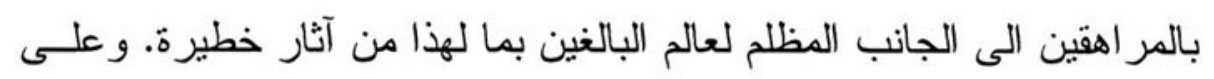

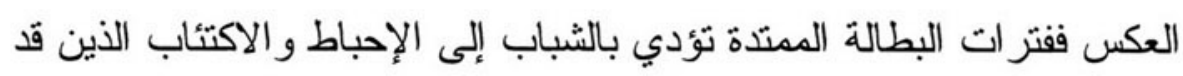

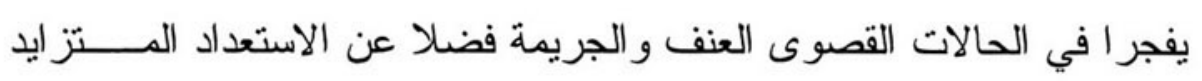
لتقبل الأفكار المنطرفة و المتعصبة.

عمل المر اهقين المبكر يمكن القول بأن عمل الأطفال وصغار المر اهقين هو من بين أفـــدح

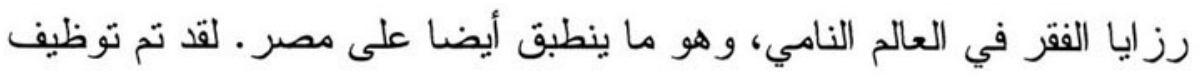

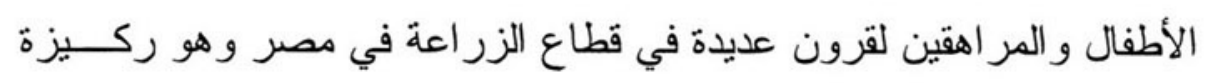


الاقتصاد. وكانت التلمذة في الطو ائف الحرفية تبدأ أيضا في سن مبكرة. ومع

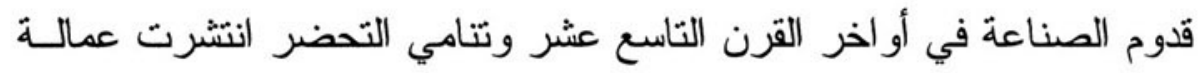
الأطفال و المر اهقين إلى القطاعات غير التقليدية مثل الصناعة و الخدمات.

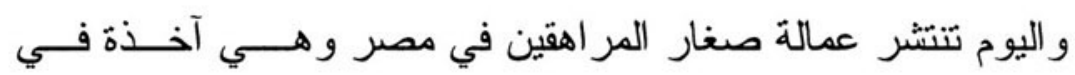

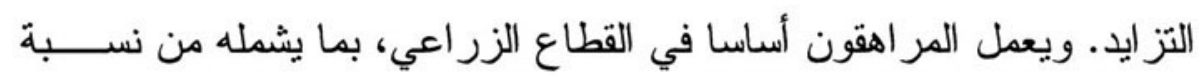

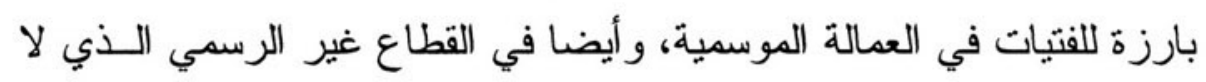

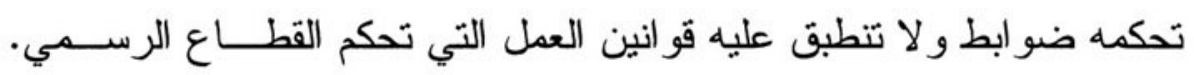

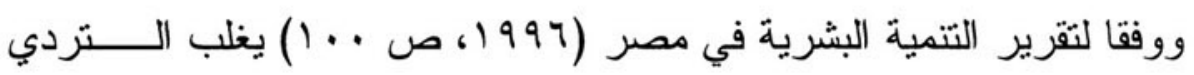

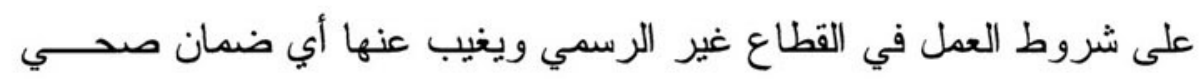

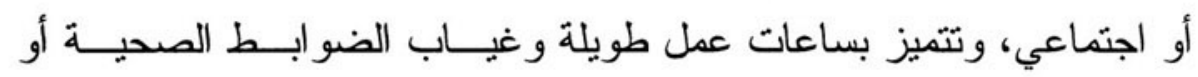

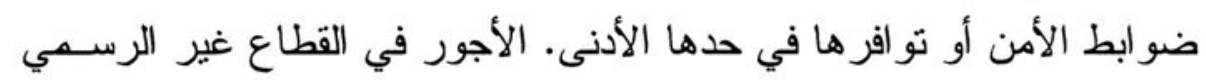

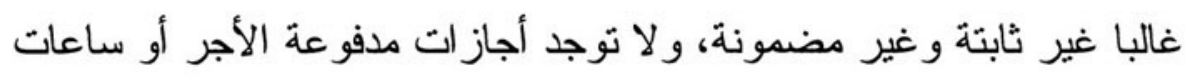

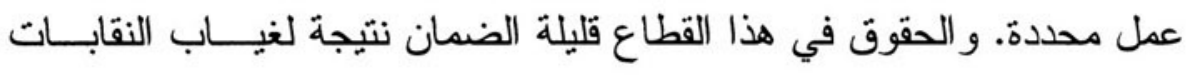

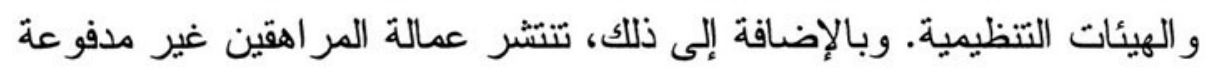
الأجر في البيوت و المشاريع العائلية. و لأن هذه النوعية من الأعمال غير رسمية وغـــير مســلة فــنـ

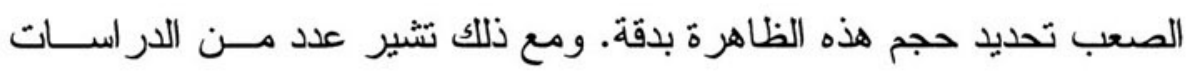

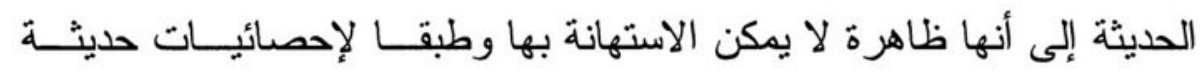

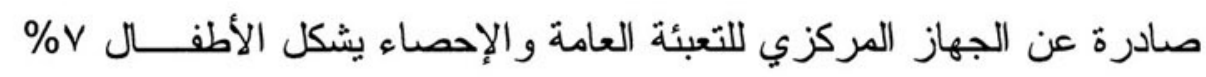

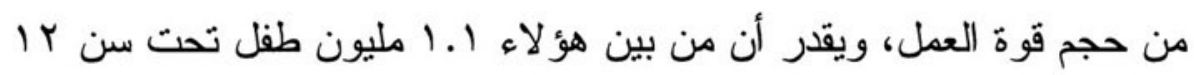

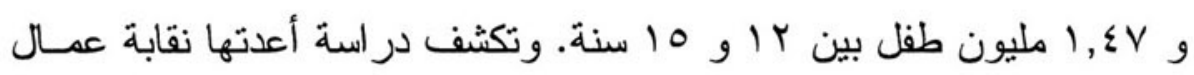

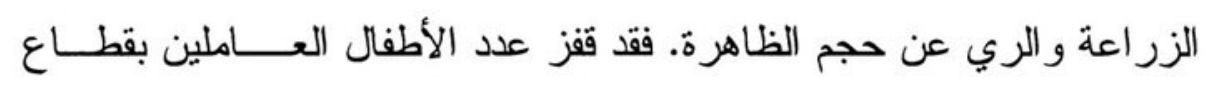


الزر اعة الذين تثز اوح أعمار هم بين السادسة و الثانية عشر من نصف مليـون

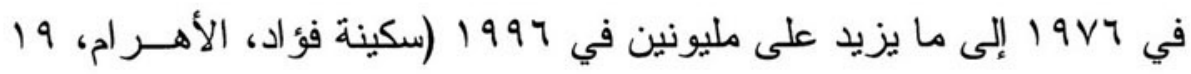
يونيو 99V ( 9 ). ووجد مسح آخر أجر اه المجلس القومي للطفولة و الأمومة أن

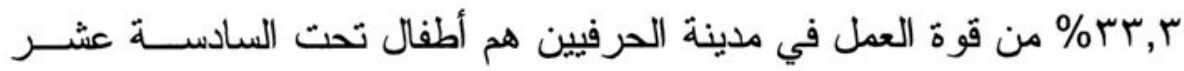

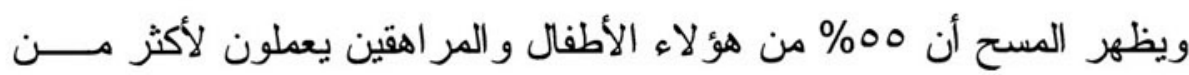

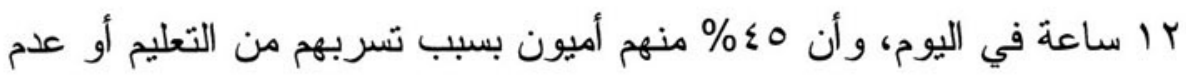

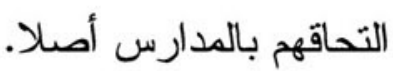

إن نمط عمل صغار المر اهقين غير موحد على الإطــــلاق. فنجـــهـ

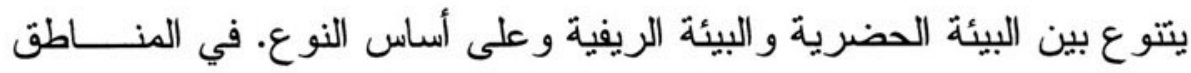

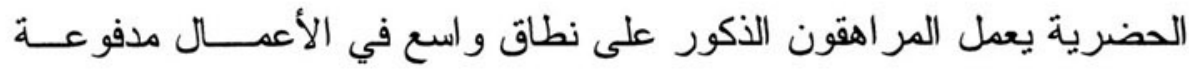

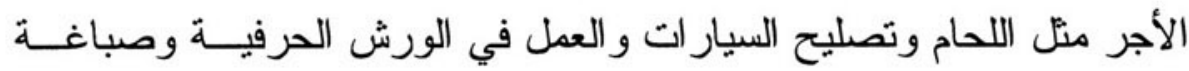

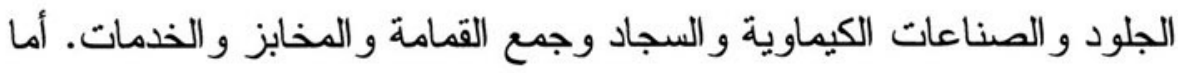

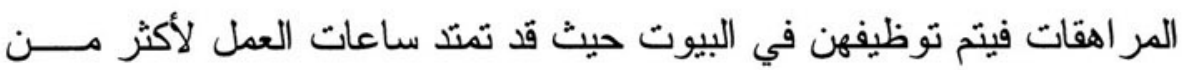

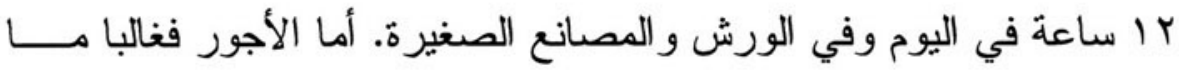

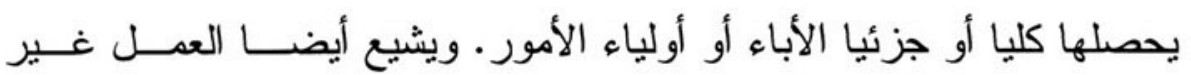

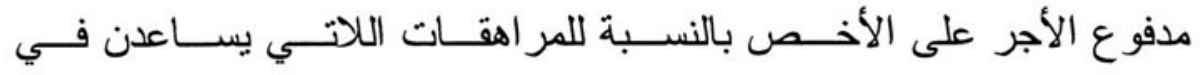
المشرو عات العائلية. وينخرط المر اهقون و المر اهقات بدرجة أقل في أعمــال غير مشروعة تتز اوح بين احتر اف التسول و الاتجار بالمخدرات و الدعـــــارة إلى أثكال أخرى من الجريمة المنظمة وجنوح الأحداث. في المناطق الريفية يرتبط نوظيف المر اهقات بأجر في العادة بالعمل

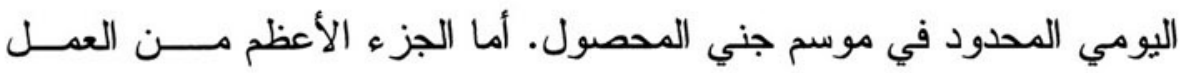

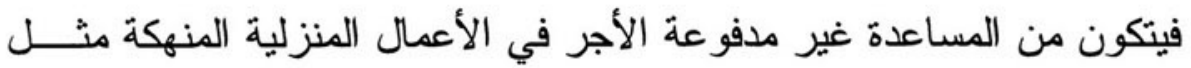


التظظيف و العناية بالأخوة الصغار و الطهي و إطعام الماشية ور عايتها و الحلب

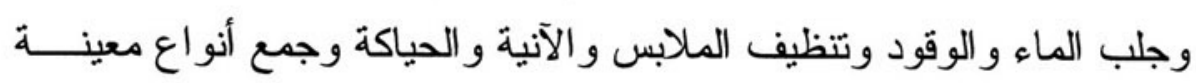

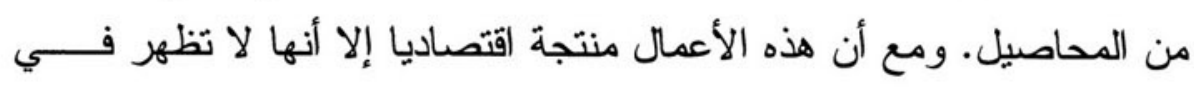

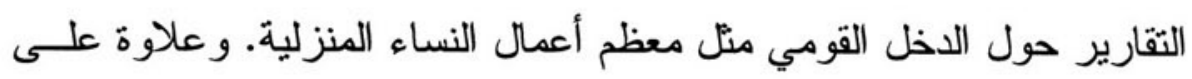

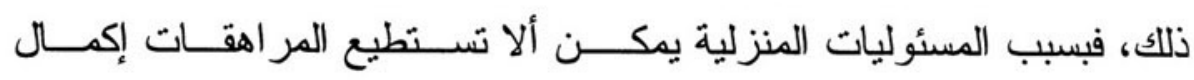
تعليمهن.

\section{السياسات و الضوابط}

إن انشغال الدولة بظاهرة عمالة الأطفال و المر اهقين الصغار يعــود

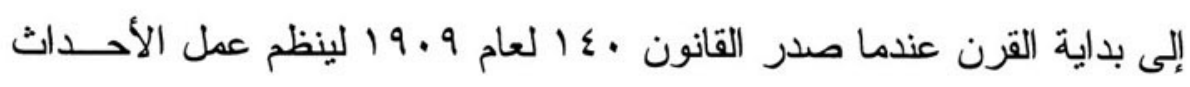

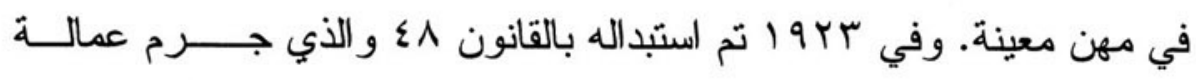

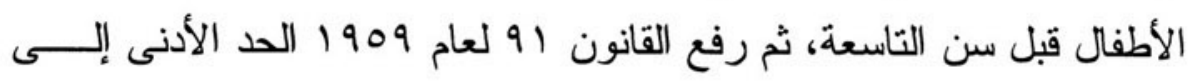
rا سنة. وكان يسنثنى من ذلك العمل المنزلي و العمل بالزر اعة و المشاركين

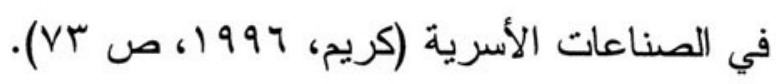

وفي 1911 صدر قانون العمل رقم VTI وخصص قسما التوظيــف

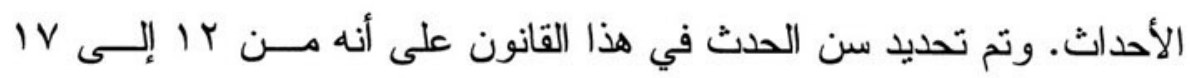

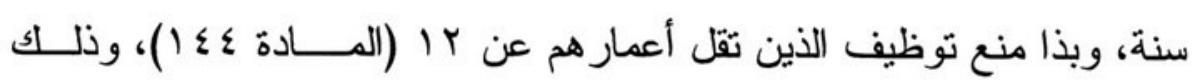
لضمان حد أدنى من التعليم و النضوج الجسدي. وهنا أيضا كانت المجمو عنان

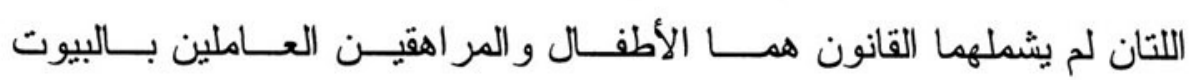

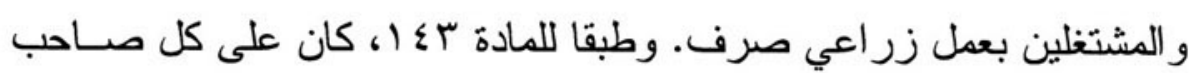

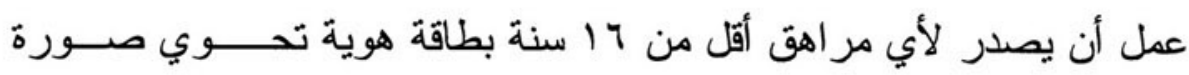

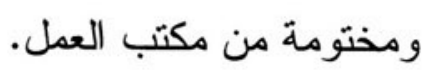


ومنع القانون أصحاب العمل من نوظيف المر اهقين تحت 17 ســــنة الذين لم يحصلوا على بطاقة الهوية التي نص عليها القانون المدني. وحدد القانون الحد الأقصى لساعات العمل اليومية بالنسبة للمر اهقيـن بست ساعات بالإضافة إلى أوقات للر احة و الطعام. كما وضع حـــدا أقصـى

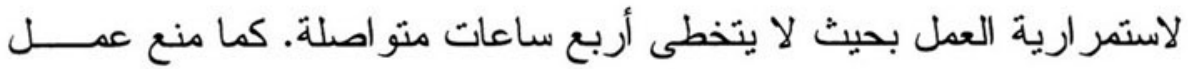

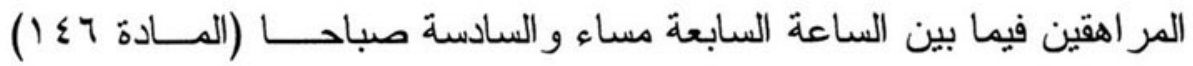
و أثناء عطلات نهاية الأسبوع وفي العطلات الرسمية. و ألزمت المــادة می

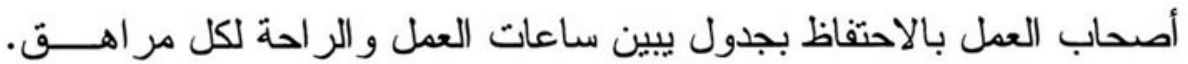
بالإضافة إلى ذلك، فرض القانون على أصحاب العمل أن بعلقو ا ذلك القســم

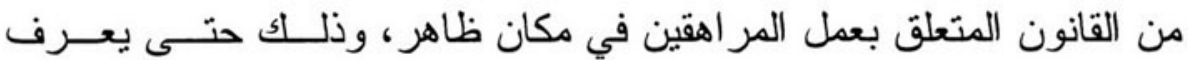
المر اهقون حقوقهم. أما أصحاب العمل الذين يخالفون القانون فيكون عليـــــ

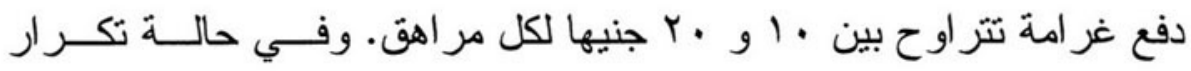

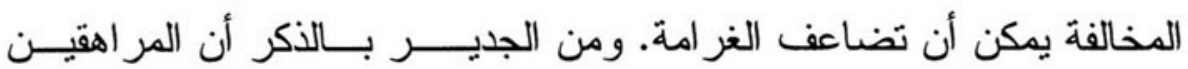
العاملين في ظل هذا القانون لم يكونو الينتفعوا من نظام التأمينات الاجنماعية

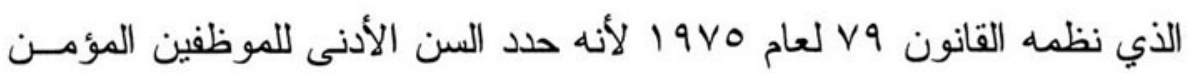
عليهم بثمانية عشر عاما. وفي الفترة اللاحقة صدر عدد من القرار ات الوزارية لزيادة ضمانات

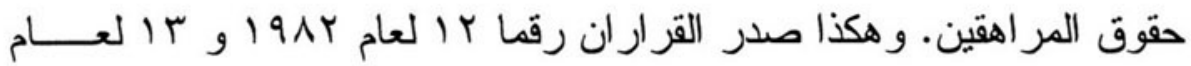
rی19 من وزارة القوى العاملة و التّريب لمنع عمل المر اهقين في صناعات معينة وبعض القطاعات التي اعثبرت ضارة بهم. ومنع القــــرار r I لعـام

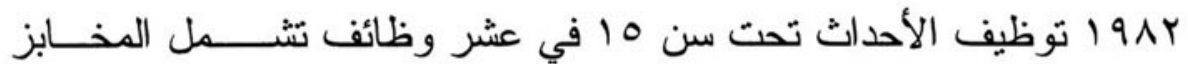
ومصانع الأسمنت وتكرير البترول ومصانع التلج و أنابيب الغـــاز ومصــانع السماد الكيماوي بالإضافة إلى الأعمال التي تتطلب جهذا شاقا منل حمل وجر 


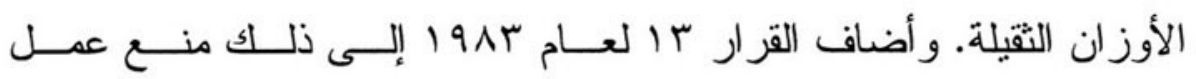
المر اهقين تحت V V سنة في ب Y مهنة، منها التعدين، وورش سباكة المعـادن

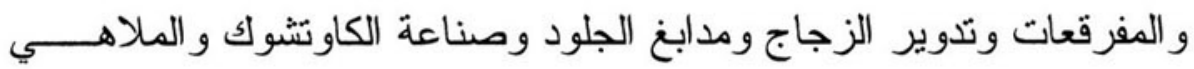

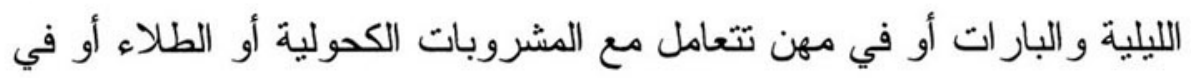
تشغيل وصيانة المعدات الثقيلة.

وبالإضافة إلى ذللك، وضع القرار الوزاري رقــم ع ا لعـام به1919

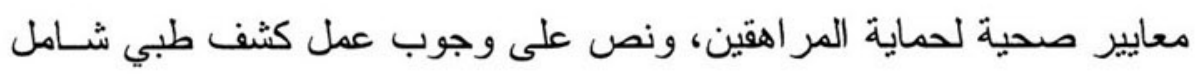

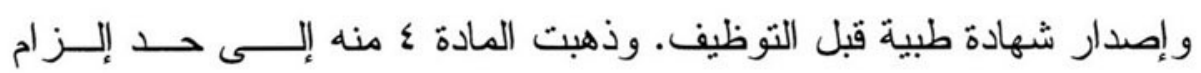

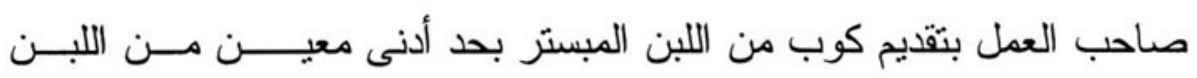

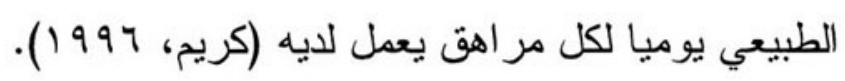

وفي عام 1997 كان هناك محاولة تثـــريعية للتعــامل مــع هــــا

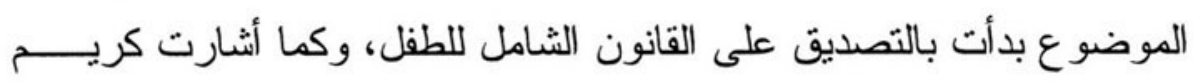

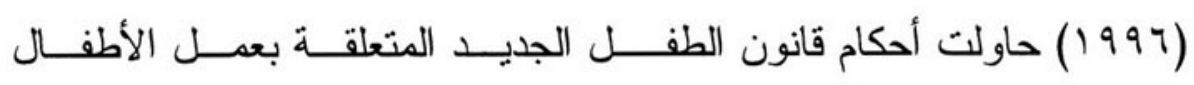

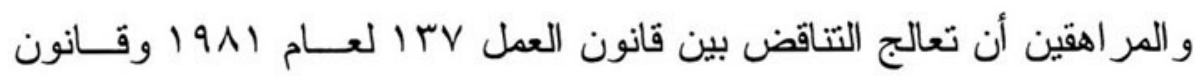

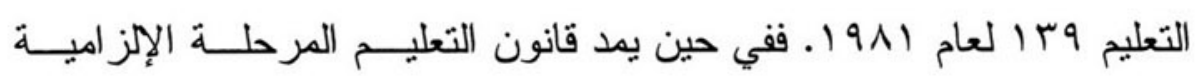

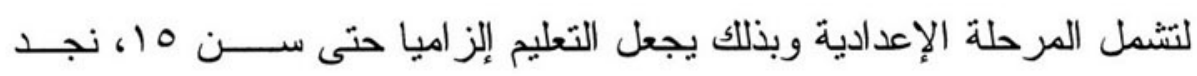

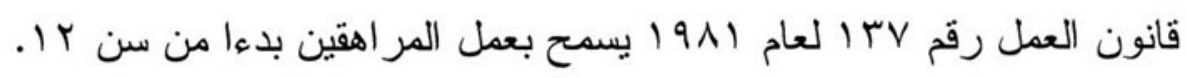

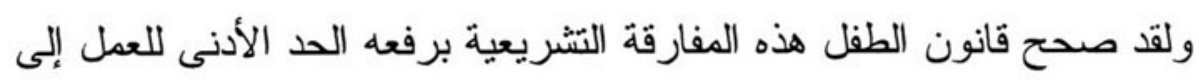

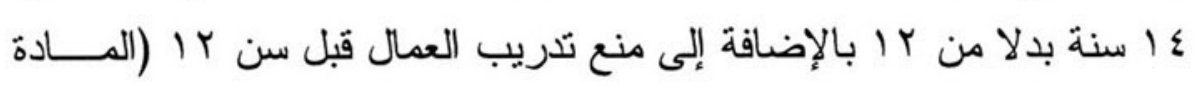

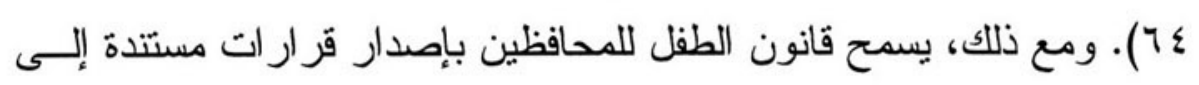

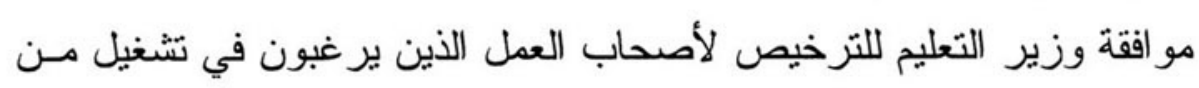


تتراوح أعمار هم بين كا و ـ ع ا في أعمال موسمية، وذلك بشرط ألا تضـــر هذه الأعمال بصحتهم أو تعوق نمو هم أو در استهم.

ويمنع قانون الطفل تشغيل الأطفال لما يزيد عن T ساعات في اليوم،

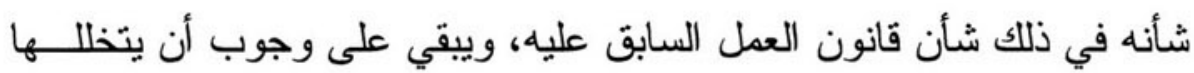

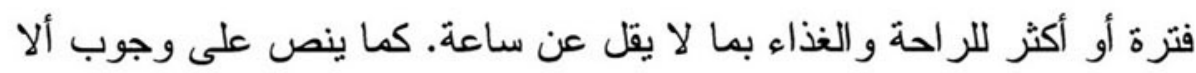

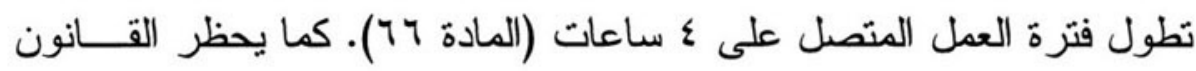

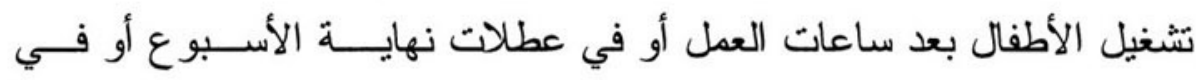

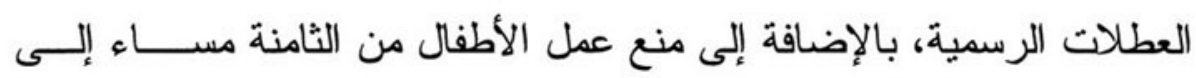

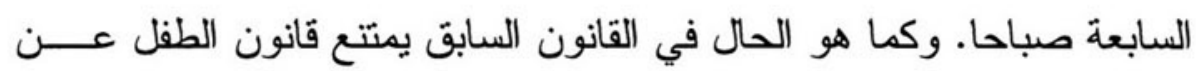

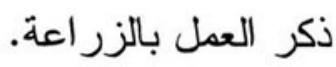

في حين يمثل قانون الطفل خطوة إيجابية لاتجاه رفع الحــــ الأدنــى

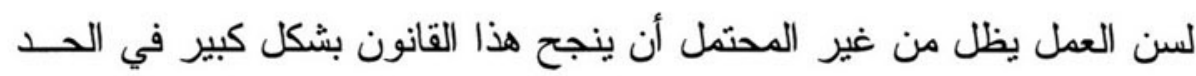

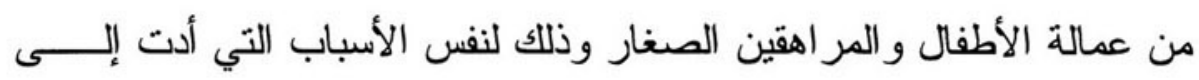

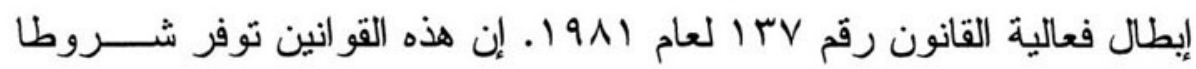
ضرورية ولكن غير كافية لمكافحة عمالة الأطفال و المر اهقين. إن الدراسة المسحية الحديثة التي أجر اها مصطفى وكريــ (1997)

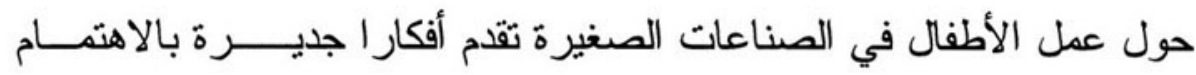

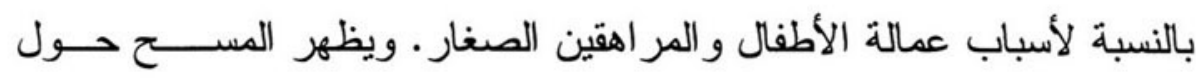

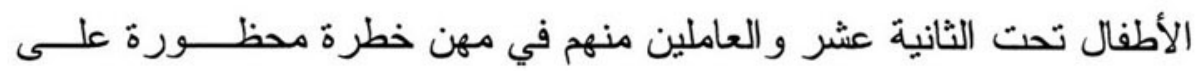

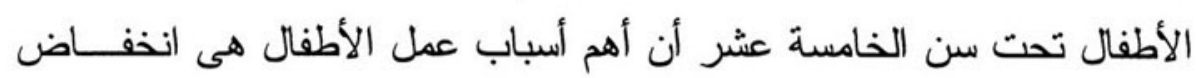

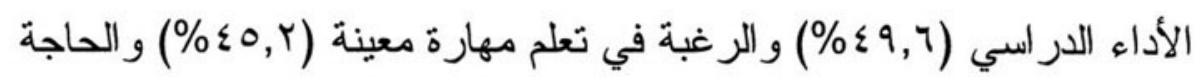

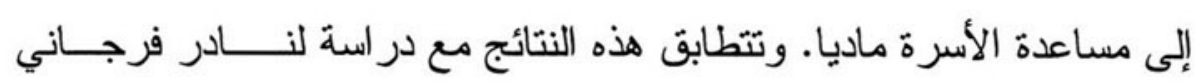




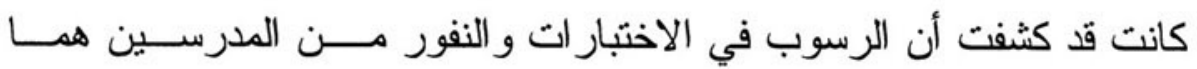

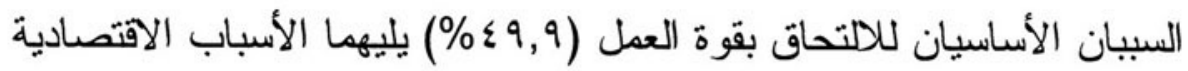

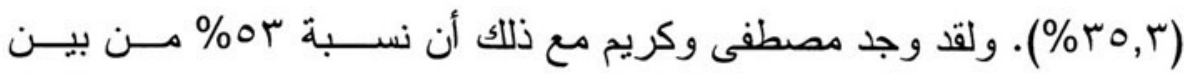

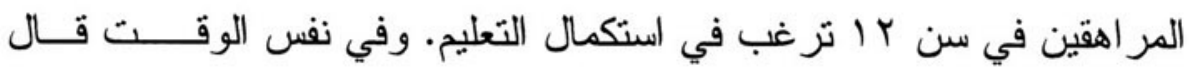

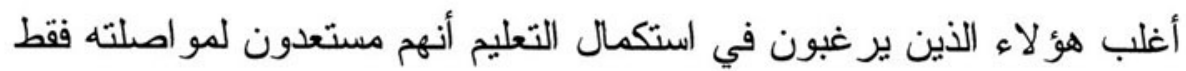

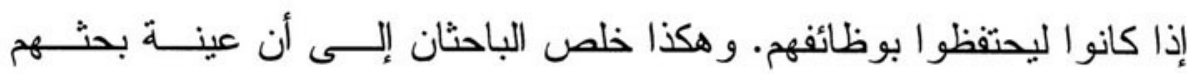

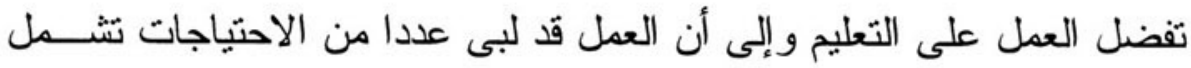

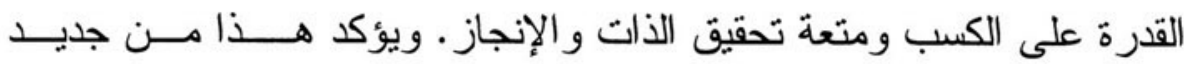

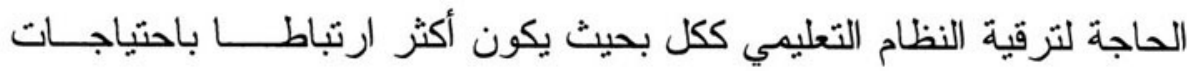
السوق وضرورة زيادة العائد الاقتصادي و الاجتماعي للتعليم.

بحلول عام 1997 كان هنالك قوة دفع متتامية داخل الحكومة باتجــاه معالجة موضوع عمالة الأطفال بشكل أكثر جدية. وفي حديث لجريدة الأهر ام

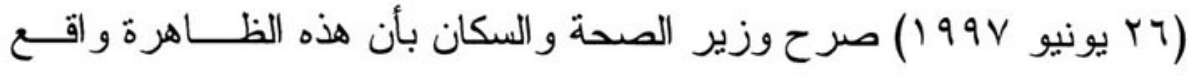
اجنماعي يصعب تغييره. غير أنه شدد على أن ظروف العمل يمكن تحسينها من خلال تضافر جهود الهيئات الحكومية و المنظمات غير الحكومية في تتفيذ تهئ عدد من الإجر اءات، مثل تقديم الوجبات وتحسين معـايير الصحسـة البيئيــة

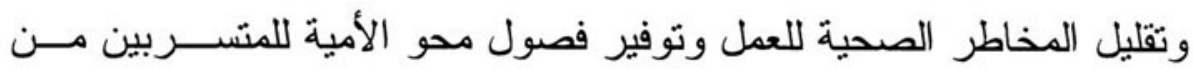
التعليم وتدريب رسمي موثق لكي تثاح لهم فرصة العمل في أماكن أخـــرى.

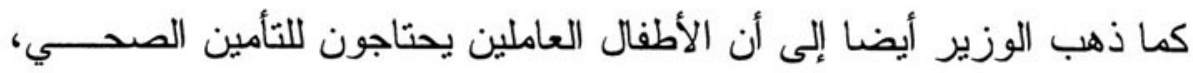

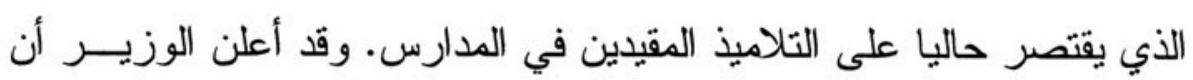

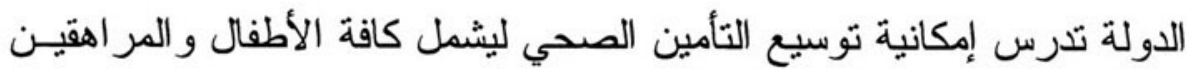

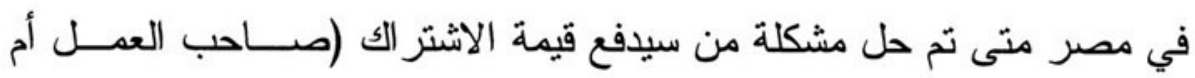


الطفل). وخلال هذه الفترة يمكن استخدام المستشفيات و العيادات العامة مـــن جانب الأطفال غير المؤمن عليهم.

إن مساعي السيدة الأولى الدعوبة في مجال دعم رفاه لاطفل أعطــت

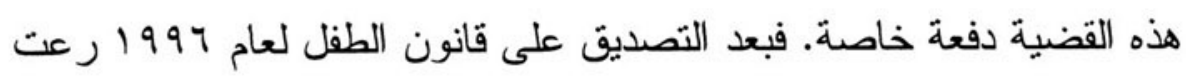

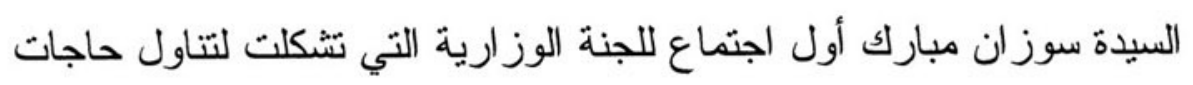

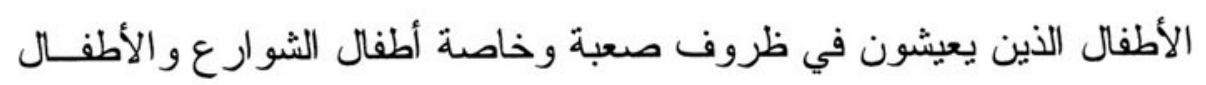
العاملين. ونتألف هذه اللجنة التي تعمل في ظل إدارة المجلس القومي للطفولة

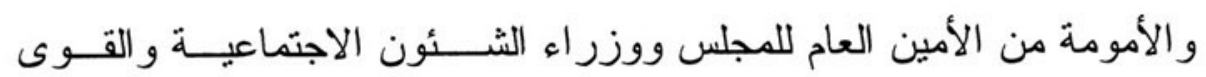
العاملة و الهجرة و الداخلية و الصحة و السكان أو من يحل محلهم.

وبدأ هذا الالتز ام السياسي يجني ثماره وتحول إلى اقتر اح متضدـــن

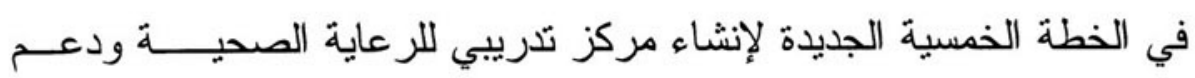

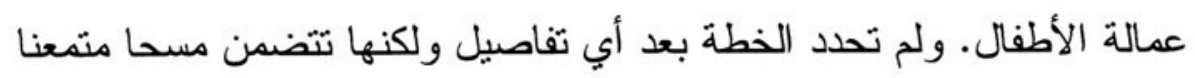

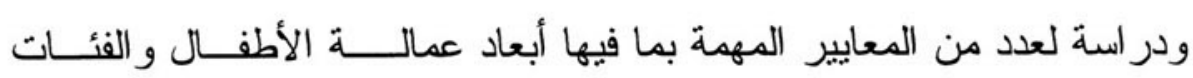
العمرية المختلفة و الوضع التعليمي وظروف العمل. كما يتضمــن الافــنر اح

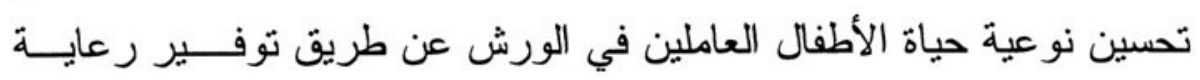

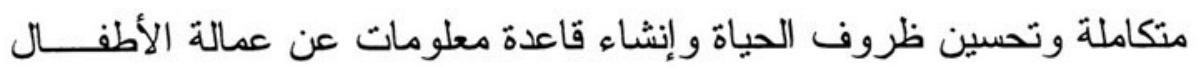

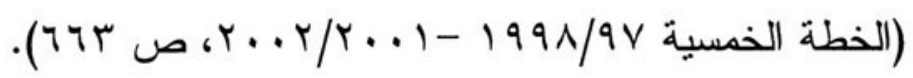

\section{البطالة بين المراهقين}

يتناسب التوظف عند المر اهقين إيجابيا مع مسنوى النشاط الاقتصادي

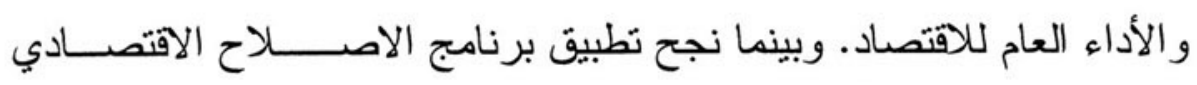

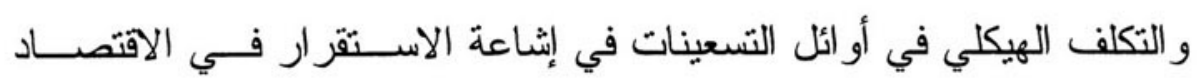

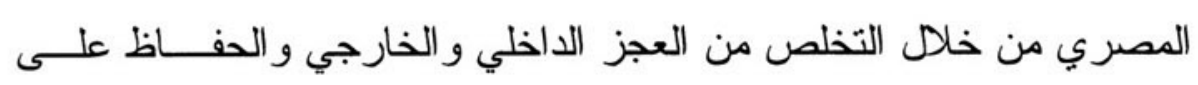


معدلات تضخم منخفضة واستثر ار العملة، فإن تر اجع معدلات النمو كان لــه

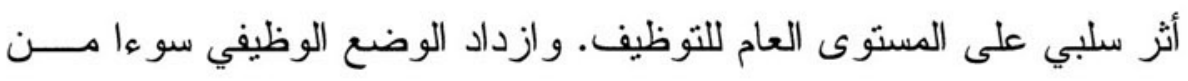

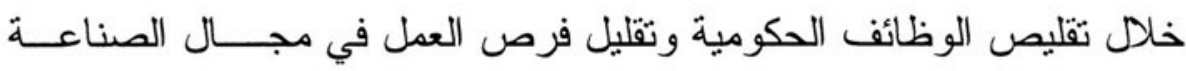

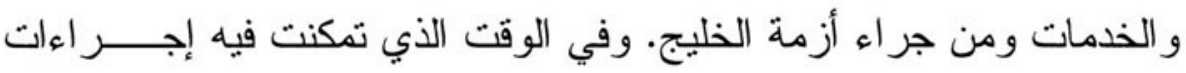

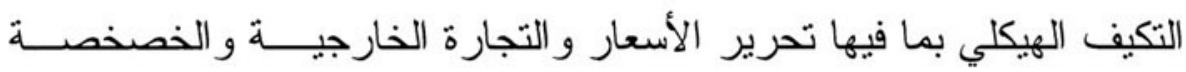

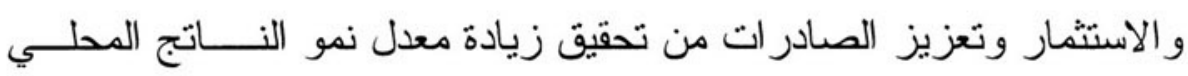

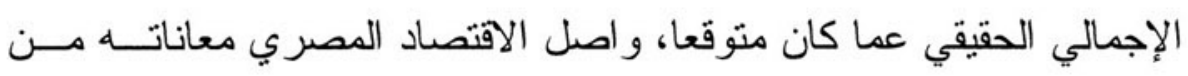

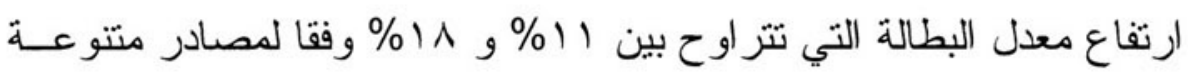

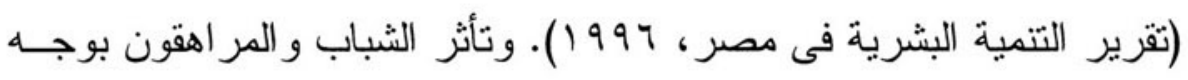

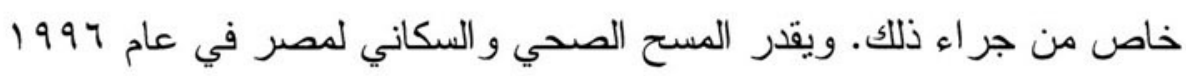

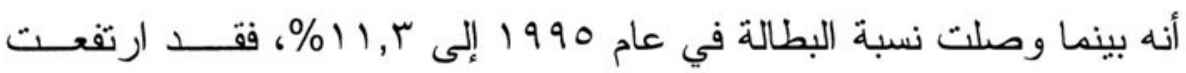

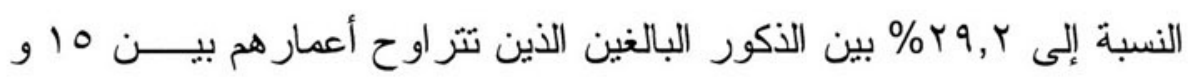

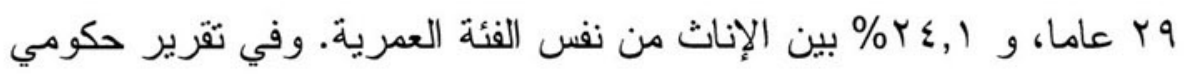

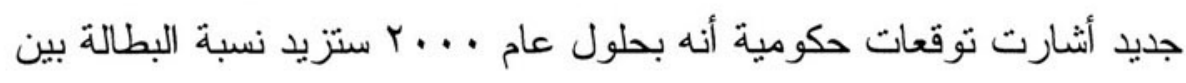
خريجي المدارس الإعدادية إلى ثلاثة أمثالها عند خريجي الجامعات أندات و إلى جانب المستوى العام للأداء الاقتصادي و إمكانيات التتمية كــان

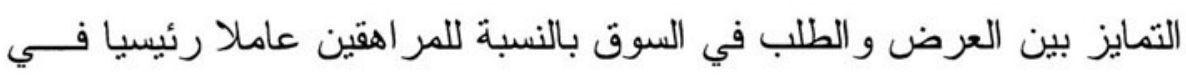

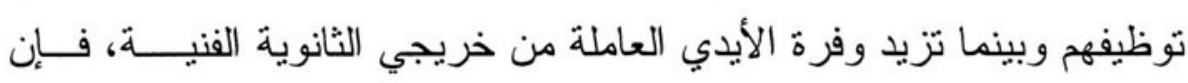

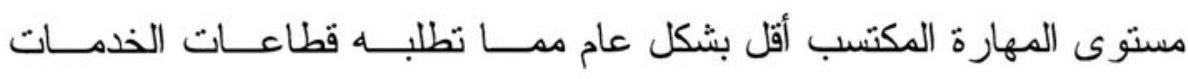

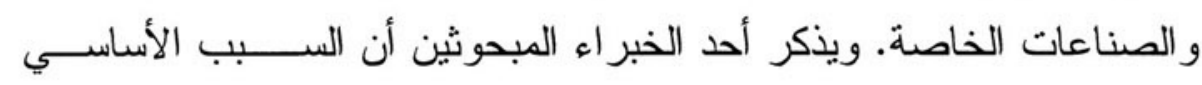

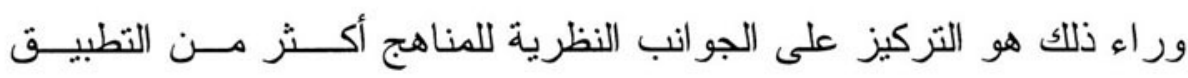

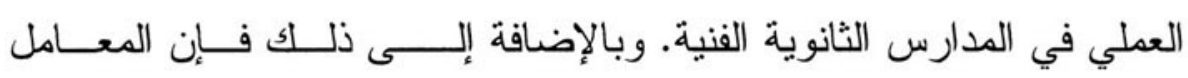
و التجهيزات قديمة العهد كما أن نقص الإمدادات لا يتيح الفرصة للطلاب لأن 


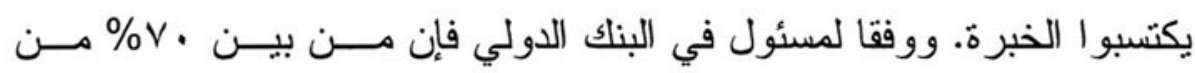

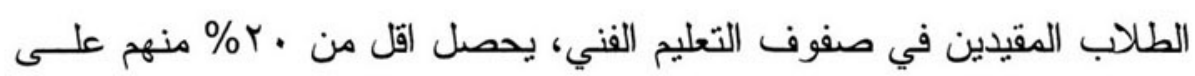

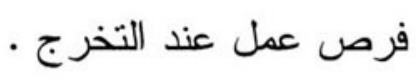

\section{سياسة الدولة و التوظيف}

جعل الدستور خلق فرص عمل من واجبات الدولة. فوفقا للمــادة اس

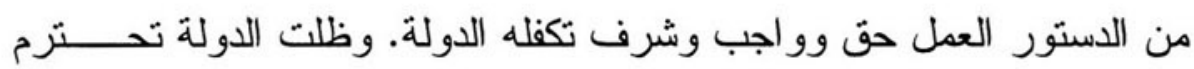

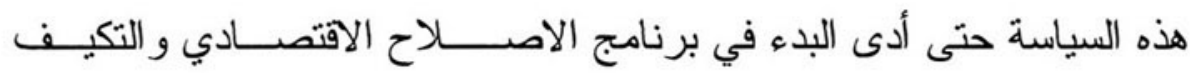

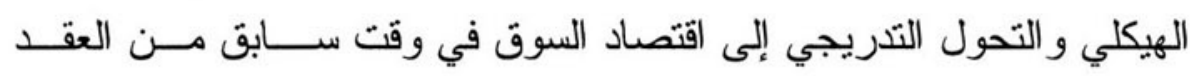

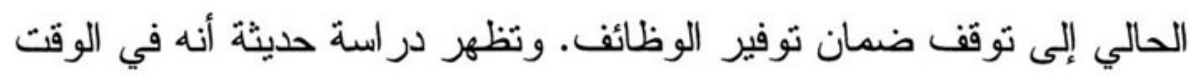

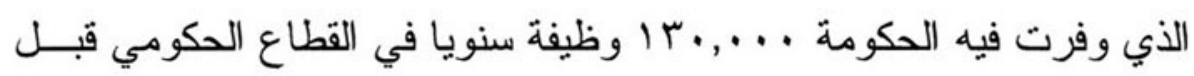

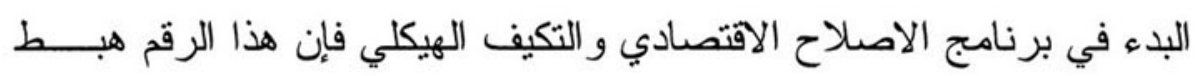

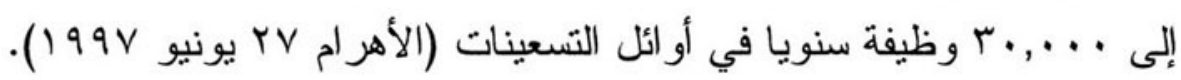

غير أن الدولة لم تتخل عن دورها في خلق فرص العمل وخاصـــــة

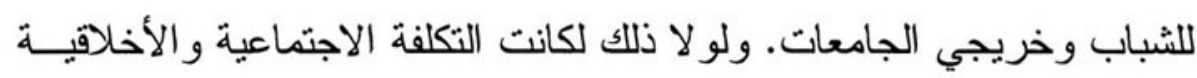

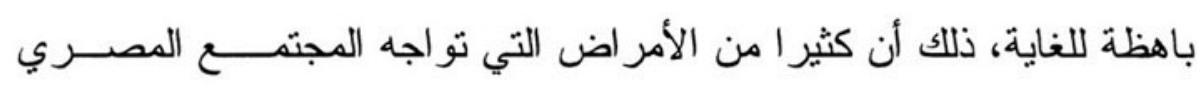

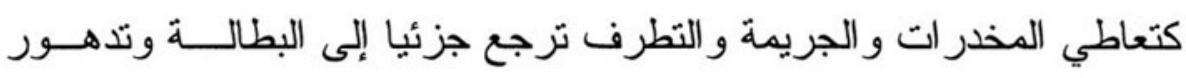

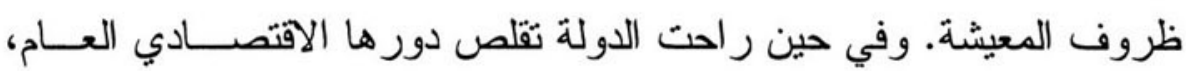

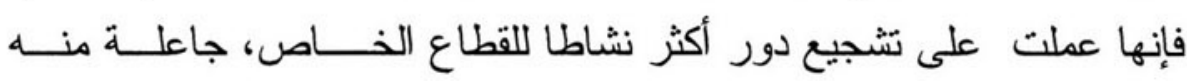

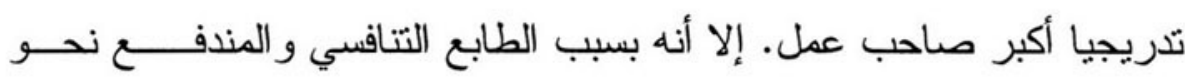

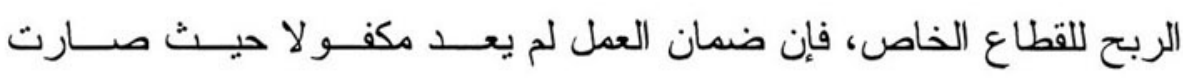

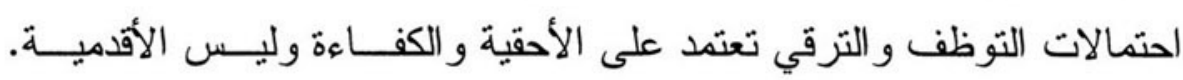


وفضلا عن ذلك، تستمر الدولة في تشجيع الصناعات و المشــروعات كثيفــة العمالة، و التي تحظى بالأولوية من جانب مؤسسات الأتثمان.

وتضع الخطة الخمسية الجديدة أولوية كبيرة لتوليد الوظائف. ويتمثل

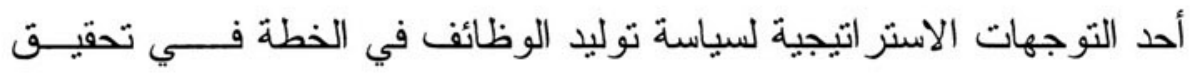

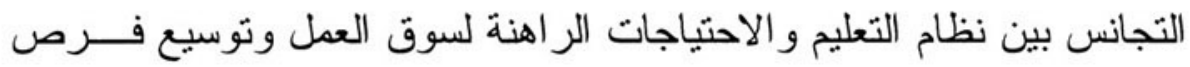

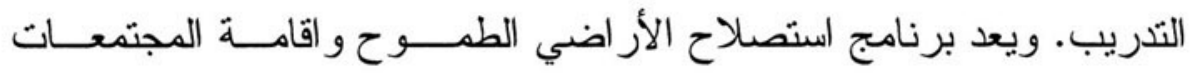

العمر انية خارج و ادي النيل الضيق، بما في ذلك تطوير سيناء ومصر العليـا وتوشكى، توجه مهم ثاني للسياسات.

وفي حين أن توجهات السياسة المتضمنة في الخطة الخمسية الجديدة

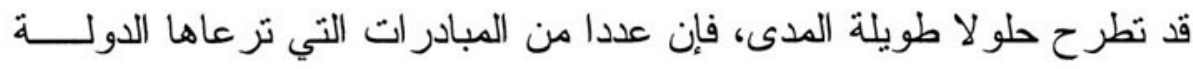

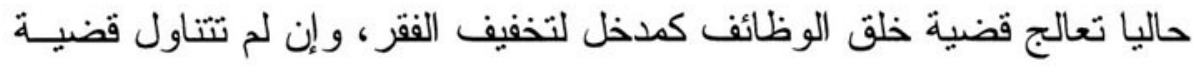

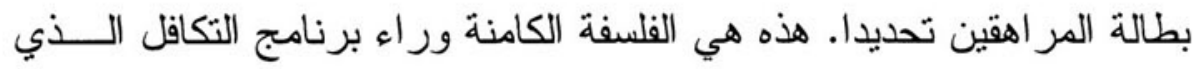

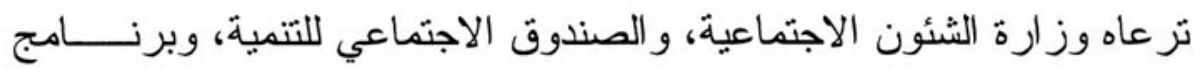

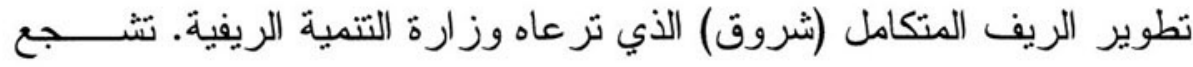

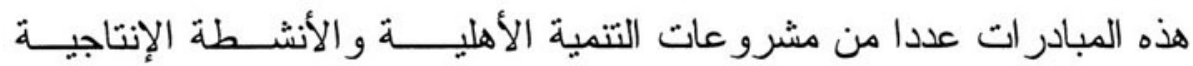
بالتعاون مع المنظمات غير الحكومية. وفي حين أن المر اهقين قد يســـتفيدوا

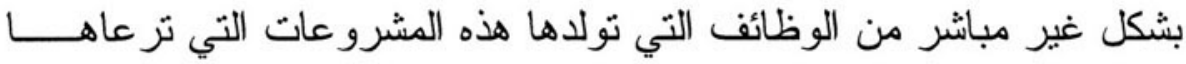

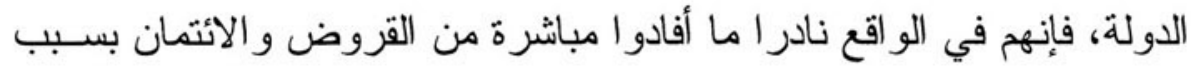

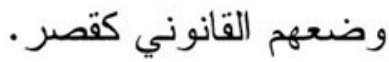

لقد واجهت مبادرة واعدة شنتها مؤخر ا وز ارة التتمية الريفيـــة فـي

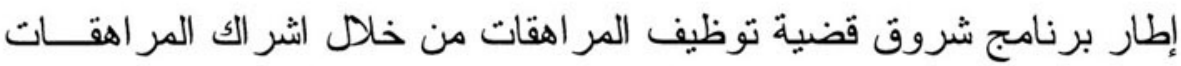

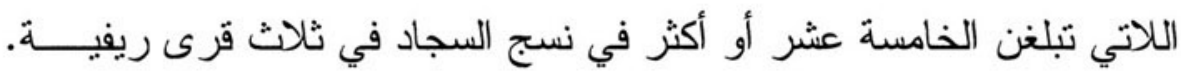


ومع توفير امكانية الحصول على مبالغ مالية من صناديق التتمبة المحليـــة،

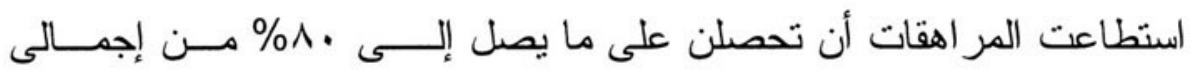

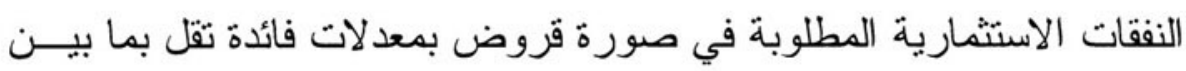

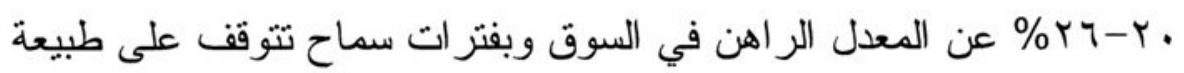

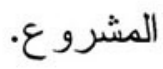

\section{التحديات الراهنة والعمل المقترح و الآفاق}

مواجهة جذور عمالة الأطفال والمر/هقين

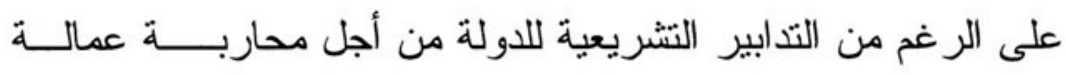

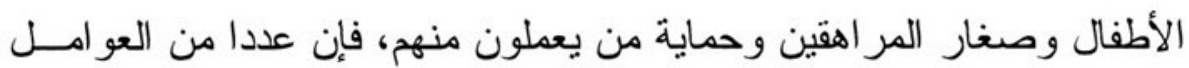

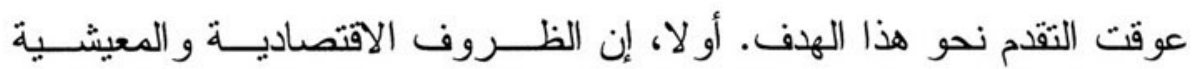

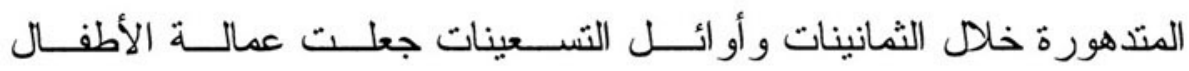

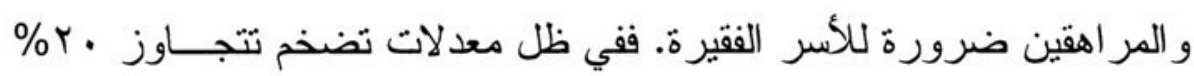

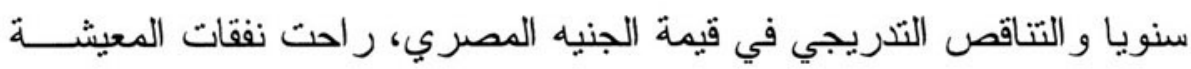

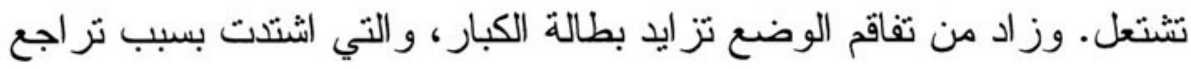

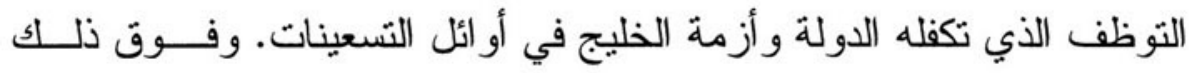

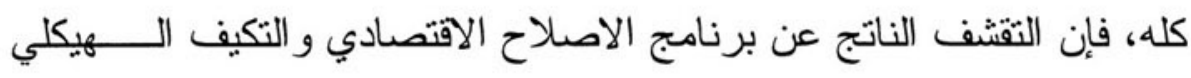

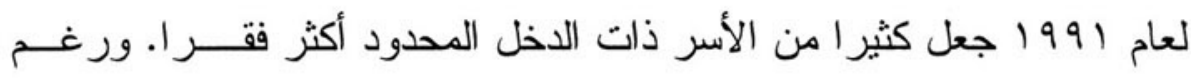

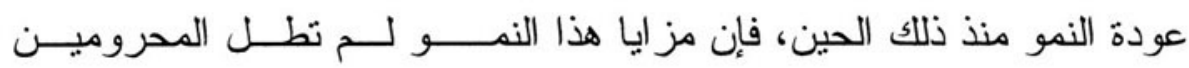
و اصحاب الظروف الصعبة. وفي ظل هذه الظروف، استمرت عمالة الأطفال

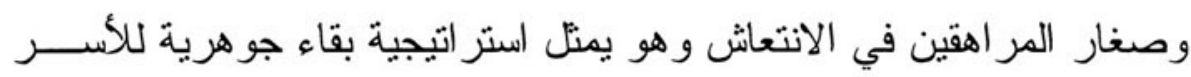
الفقيرة من أجل الاستمر ار فى الحياة. 
ITV ويتصل السبب الثــاني بنطــاق شــمول القــانون. فالقــانون و القر ار ات المصاحبة له تغطي أساسا التوظيف في القطاع الرسمي. ويــنرك ذلك نسبة و اسعة من الأطفال و المر اهقين العاملين في القطاع غير الرســـي بمنأى عن حماية القانون، وبالتالي في وضع قابل بشكل خاص للاســــتـلال و الانتهاك. وفضلا عن ذلك، لا ينطبق القانون ITV علــى عمــال الخدمــة المنزلية حيث احتج صناع السياسة بأنه من المستحيل وضع القو انيـن التـي تشمل هذه الفئة موضع التنفيذ. ويمنل المر اهقون الريفيون المنخرطون فــي العمل الزر اعي مجمو عة أخرى و اسعة و غير محمية. ويتعين الاعتر اف بأنـه يصعب على القانون أن يغير أسلوب الحياة الاجتماعي الثقافي و الاقتصـــادي في الريف المصري، حيث ينظر لعمالة الأطفال و المر اهقين كأصل ثــــابت. ومع ذلك فإن العو اقب باهظة الثمن بالنسبة للمجتمع و الأفراد، وهي ثتضمـنـ انخفاض معدل الالتحاق بالمدارس خاصة بالنسبة للبنات، وبالتــالي انتشــار

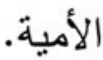

ويتعلق السبب الثالث بوضع القانون موضع التنفيذ. ففـــي حيــن أن القانون Vr ا و القرار ات الوز ارية المصاحبة له توفر نظريا درجة عالية مـن الحماية للعمال الأطفال، فإن الواقع يختلف عن ذلك كثير ا. فصعوبات النطبيق بسبب التكلفة العالية لوضع القانون موضع التطبيق، و التو اطؤ بين أصحـــاب العمل ومفتشي العمل، و الغر امات الزهيدة التي تفرض على المخالفين جعلـت هذا القانون أداة غير فعالة في محاربة استغله عمل المر اهقين الصغار. لهذه الأسباب كانت ظاهرة عمالة الأطفال وصغار المر اهقين بـــؤرة اهتمام كبير من البحوث و المداولات الحكومية. إن اقتر احات تخفيف المعانـاة وتحسبن الرفاه من خلا توفير الوجبات و المدارس التي يمكن الوصول إليها 
وفصول محو الأمبية والأنشطة التزويحية هي حلول مطلوبة علــــى المــدى القصير • أما على المدى الطويل، فإن تحسين مستوى معيشة الأسر وضمــان

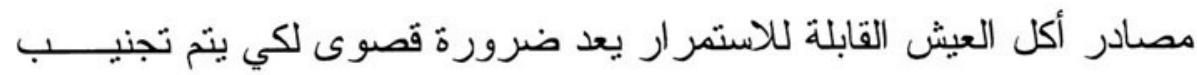
الأطفال و المر اهقين العمل المبكر · ويشير أحد خبر اء التشريع الاجتماعي إلى أنه لما كان عمل الأحداث مشكلة اقتصادية وليس ثشريعية، فإننا بحاجة إلـى الـى حلول اقتصادية. وباللتوازي مع ذلك، ينبغي تعظيم قيمة و عو ائد التعليم. يجب جعل المدارس أكثر جذبا للتلامبذ من خلال عدد مــن التحســينات الكيفيــة. ويتعين على وجه الخصوص أن توفر المناهج مزيدا من المهار ات العمليــــة و أن تلبي الاحتياجات المختلفة للمر اهقين، خاصة في المناطق الريفية حيـــث تزتبط الحياة بالزر اعة.

فتح قنوات جديدة أمام المر/هقين العاطلبن على الجانب الآخر ، فإن البطالة بين المر اهقين الأكبر ســـــنـا تمثـــلـ شاغلا مماثلا في الأهمية. إن معدل البطالة بين الشباب في سن 0 - ـ ب من أعلى المعدلات في مصر • وفي مواجهة هذه القضية، أدخلت الدولة تحسينات متو اضعة في بعض المدارس الفنبة كما أدخلت بر امج تدريب مـــــي مهمـــة

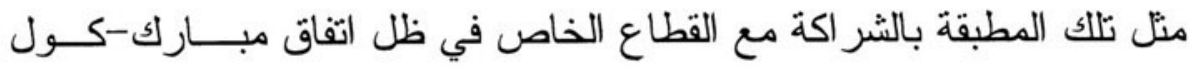
الذي رأى النور في منتصف التسعينات. وكما هو الحال بالنســـــــة للخدمـــة

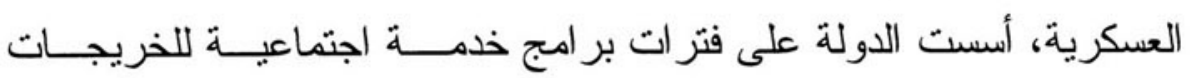
لتأجيل دخولهن إلى سوق العمل. وقد يكون من الضروري اللجوء لاقتر اب ذي جانبين لإيجاد حلــــول طويلة المدى لتلك المشكلة. من ناحية، من الضروري إجر اء مر اجعة شـاملة لنظام التعليم الفني الر اهن بهدف رفع نو عية التعليم ونوثيث صلتـــه بــالو اقع 
و إير از أبعاده العملية. سيكون من شأن ذلك أن بضمــن حصــول خريجـي

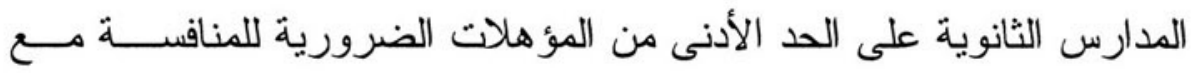
خريجي الجامعات و الكبار العاطلين على نفس الوظائف.

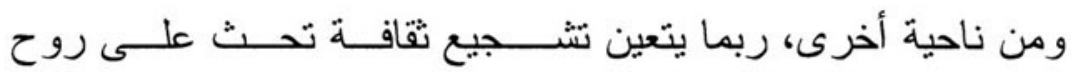

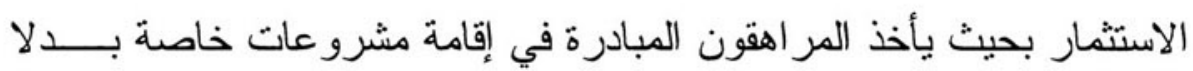

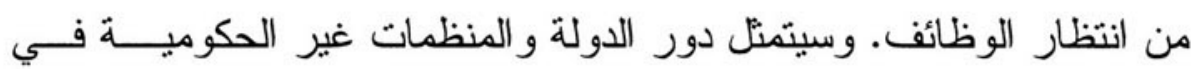
توفير الائمان و التدريب و المعونة الفنية دعما لهذه المشروعات إما من خلد المؤسسات القائمة مثل الصندوق الاجتماعي للتنمية وصناديق التتمية المحليـة

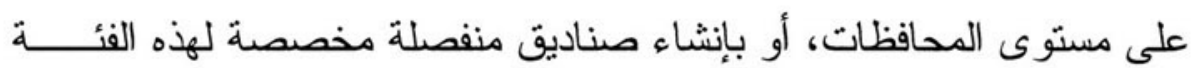

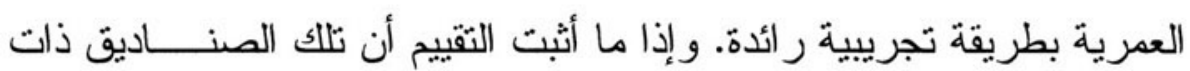
جدوى، فمن الممكن تعميم التجربة على المستوى القومي. 
أنشطة وقت الفر اغ عامل مؤثر في حياة الثباب، وهي إما تسهم فـي

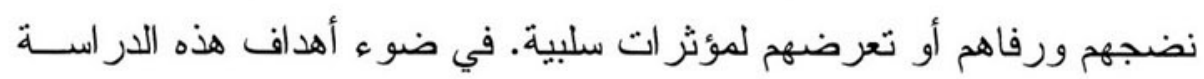

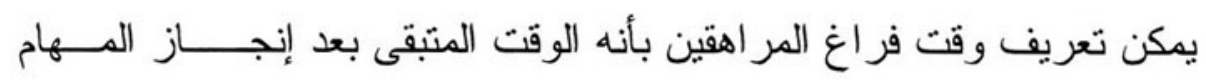

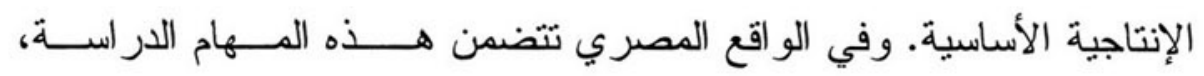

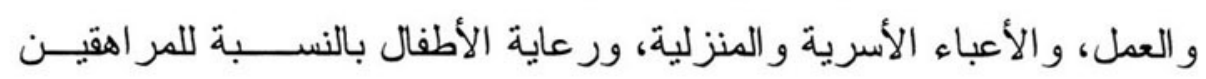

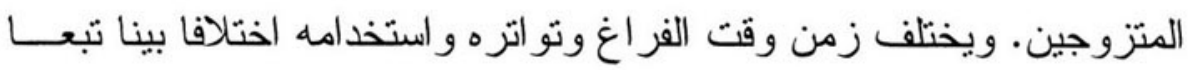

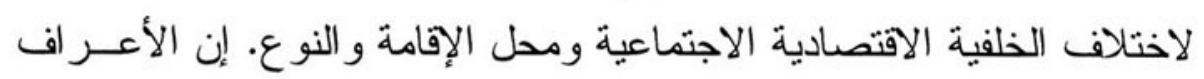

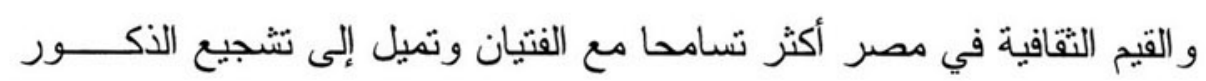

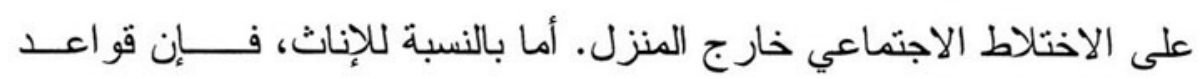

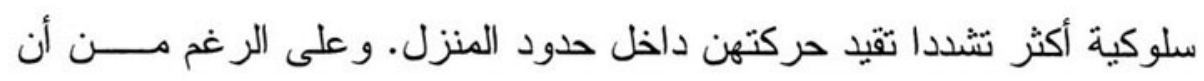

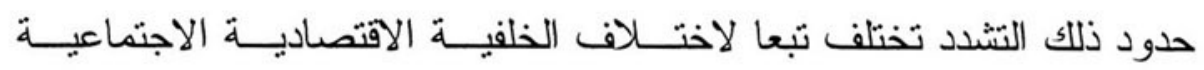
و الثقافات الفرعية والأصول ما بين ريفية أو حضرية، إلا أن الوسائل المتاحة

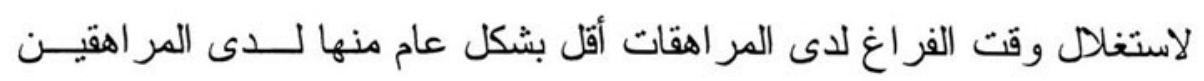

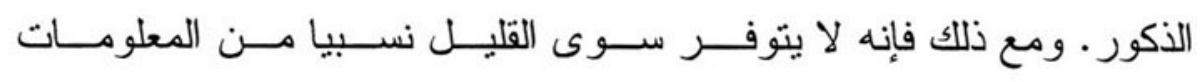
و الاحصائيات حول نمط استغلال وقت الفر اغ لدى المر اهقين في مصر .

من جانب آخر ، قد يكون لوقت الفر اغ طبيعة مختلفة كليـــا بالنســبة

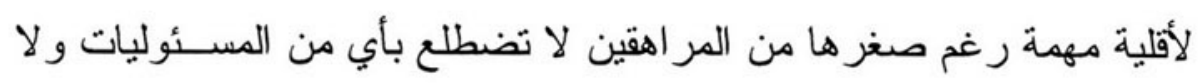

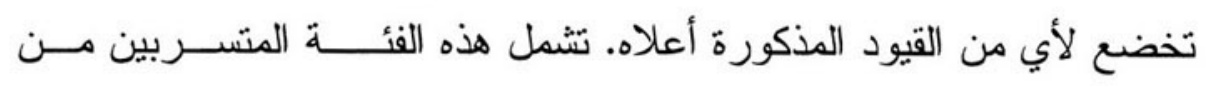

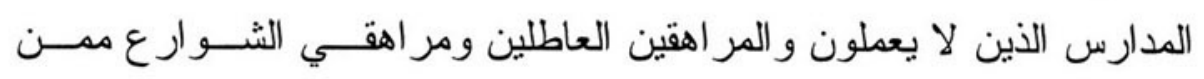

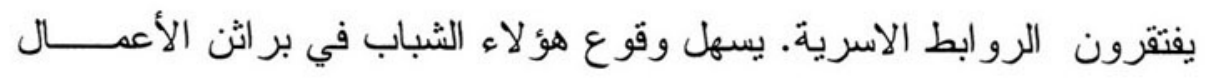

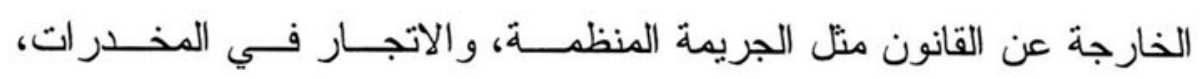


و الاعارة، و العنف، و الإرهاب المرثبط بالحركات الأصولية. وقد يمتذ وقــت الفر اغ بالنسبة لهذه الفئة ليشغل اليوم بأكمله مما بهدد الأمن و النظام العام. ولا شك أن لأنماط استغلال وقت الفر اغ استتباعات مهمة ليس فقـــ بالنسبة للمر اهقين و إنما أيضا بالنسبة لأسر هم و المجتمع و الدولة. وقد يكـــون الدئ

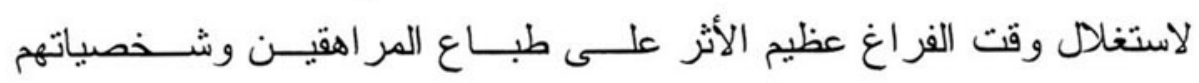

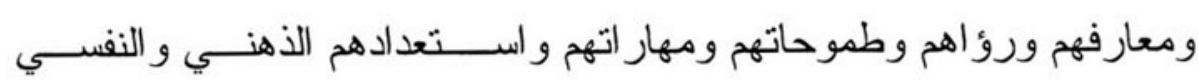

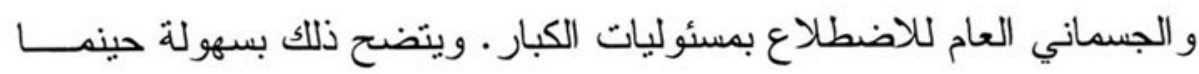
نقارن الذين بمضون معظم أوقات فر اغهم في مشاهدة التليفزيون بأولئك الذين يمضون وقت الفراغ في القراعة أو ممارسة الرياضة أو أنشطة أخرى خارج

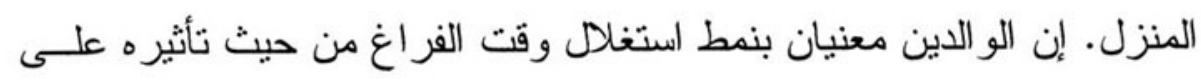

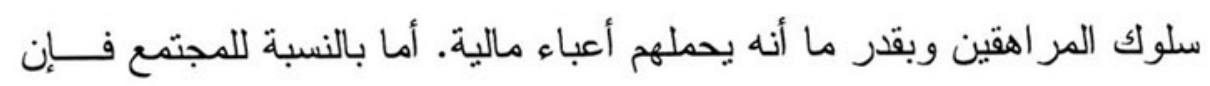

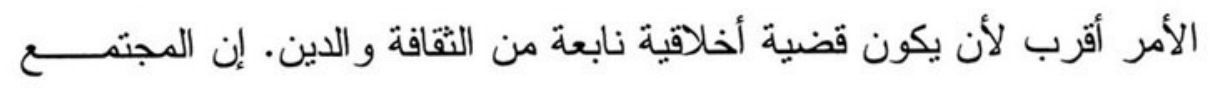

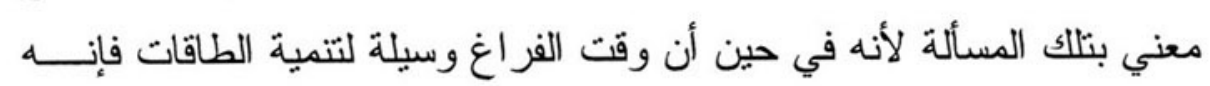
بمكن أن يمثل أيضا نهديدا اجنماعيا إذا ما تم استغلاله بطرق ضنارة. ومســن

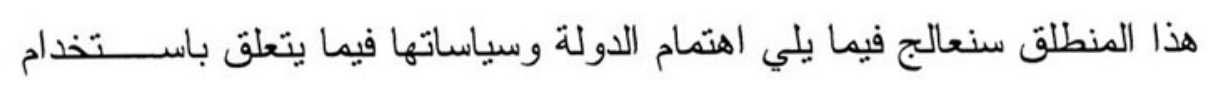
وقت الفراغ عند المر اهقين.

\section{الدولة ووقت فراغ المر اهقين: منظور عالمي}

في كثير من البلدان لا تثسم سياسة الدولة إز اء استخلال وقت الفـراغ اغ

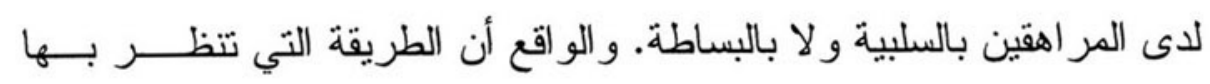

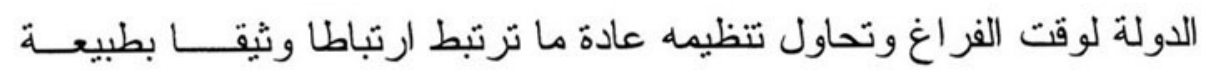
النظام السياسي القائم، وحدود الممارسة الدمقر اطية، ومدى احـــتر ام حقـــوق

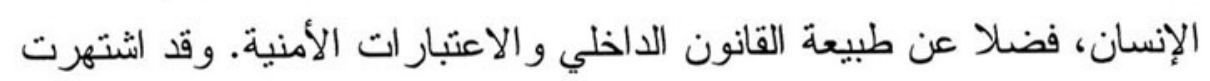


الدكتاتوريات على امتداد العالم بتقييد أو حتى منـــع الثـــباب مــن التعبـير

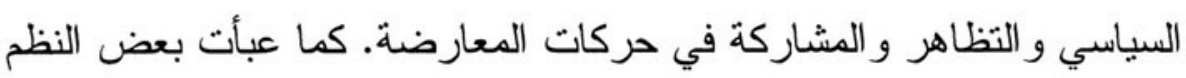

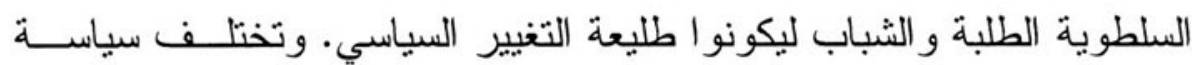

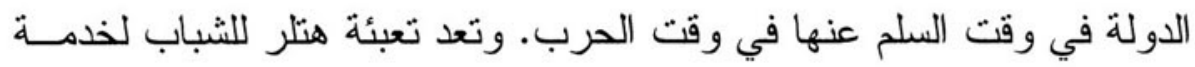

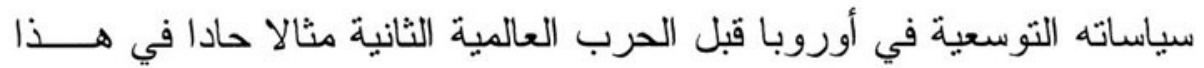

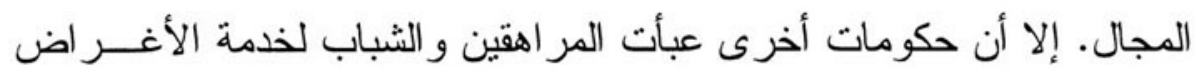
السلمية مثل محو الأمية وتخفيف الفقر وحماية البيئة.

\section{سياسة الدولة في مصر : خلاصة}

يكثف نحليل سياسة الدولة في مصر إز اء وقت فر اغ المر اهقين عن

استر اتيجتين وتوجهين للسياسات مرتبطين ارتباطا وثيقا. يسعى توجه السياسة

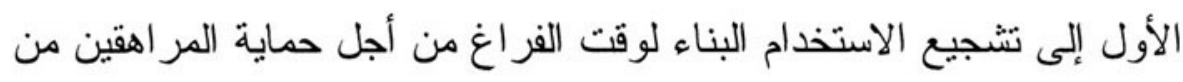

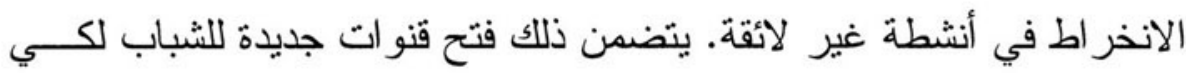

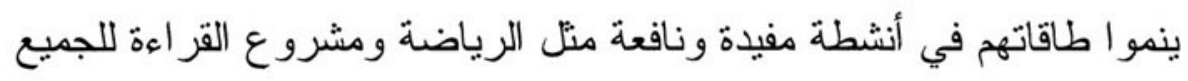

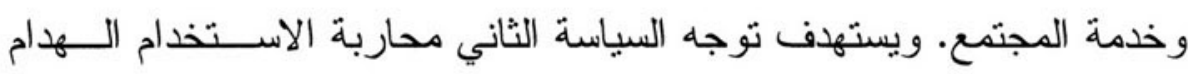

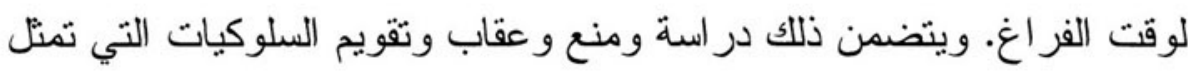

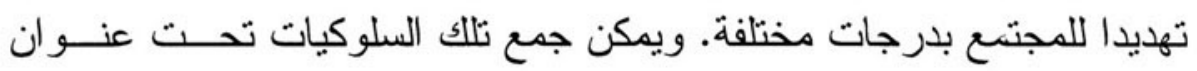

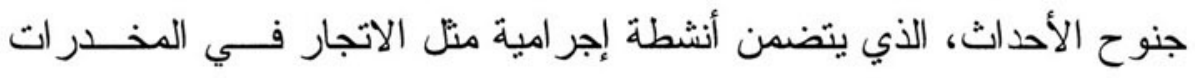

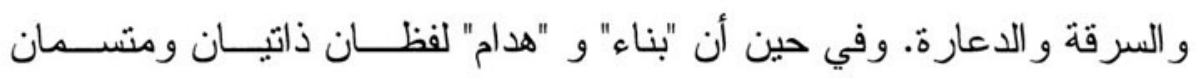

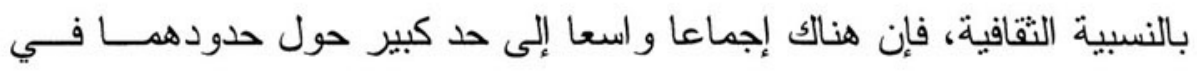
إطار الأعر اف والمعايير المصرية.

وقبل أن نخوض بتوسع في السياسات و البر امج المحددة في هذيــــن

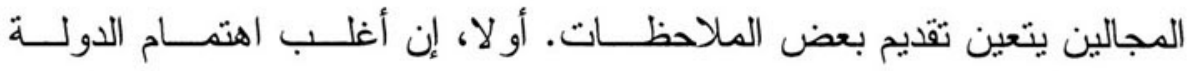


بموضوع استغلال وقت الفراغ يعطي الأولوية للمر اهقيـــن الذكـــور علـى المر اهقات. ويجد هذا التحيز جذوره في التقاليد الثقافية التي تعتبر أن الفضاء

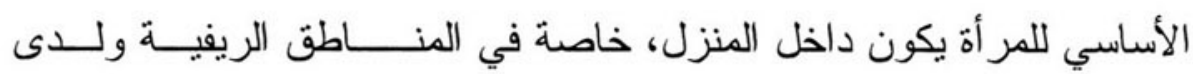
الثقافات الفرعية الأكثر محافظة. ولأن الأسرة نادر ا ما تشجع الأنشطة البناءة

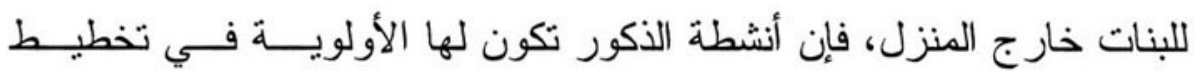
الدولة. وبالمنطق نفسه فإن المر اهقات يعتبرن أقل خطورة على المجتمع مـن

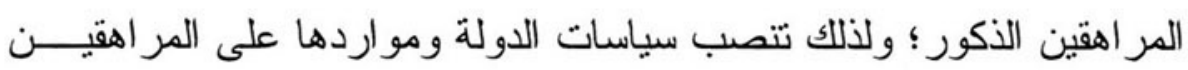

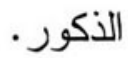

وثانيا، فإنه في حين أن الدولة تعطي أهمية بارزة لر عايـــة أنشــــة

وقت الفراغ البناءة، فإن توجه السياسة الثاني (محاربة الاستخدام الهدام لوقت الفر اغ) له فيما يبدو الأولوية حيث أن له نأثير ا مباشر ا على القانون و النظــام

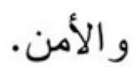

\section{تشجيع الاستخدام البناء لوقت الفراغ}

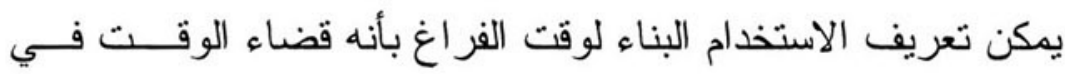

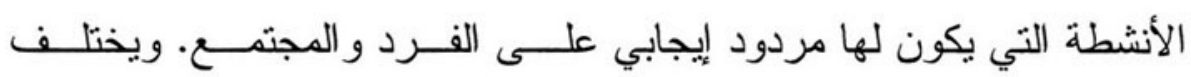
الاستخدام البناء لوقت الفر اغ باختلاف الســـن و النـــوع و التقافــة و الخلفيـــة الاقتصادية الاجنماعية. لا نعلم الكثير عن النمط الدقيق لاستخدام وقت الفراغ

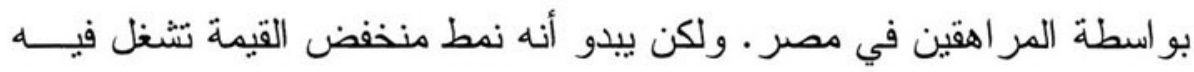
مشاهدة التليفزيون و التفاعل داخل المنزل ساعات طويلة (انظر : ثقرير النشء و التغيير الاجتماعى فى مصر، تحت الطبع). وفي حين أن الفرق الرياضيــة ونو ادي الشباب تحصل على دعم من جهات حكومبة وخاصة، فإنها نـــخدم من جانب أقلية من المر اهقين. 


$$
\text { سباسات وبرامج الدولة }
$$

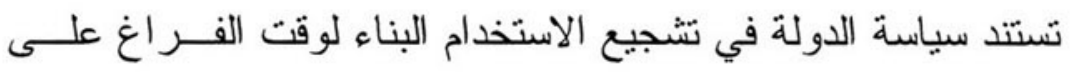

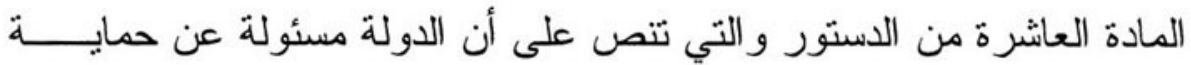

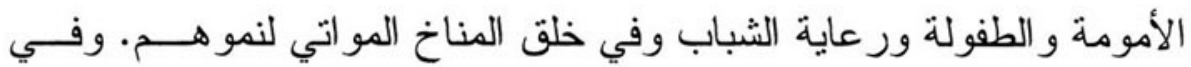

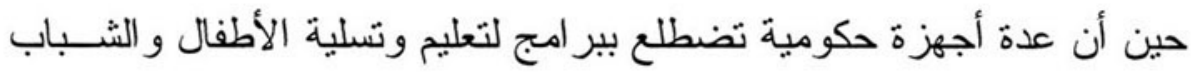
مثل برنامج "القر اعة للجميع" الذي تتبناه وز ارة الثقافة تحت رعايـــــة ســيدة مصر الأولى، فإن هذا القسم من الدر اسة سوف يركز أساسا على الرياضـــة.

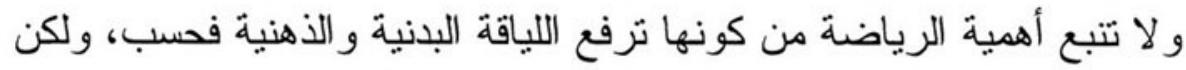

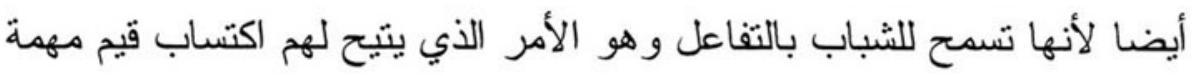
متل روح الفريق وروح المنافسة وتحمل المسئولية.

إن الجهة الحكومية المسئولة عن رعاية الرياضة هي المجلس الأعلى

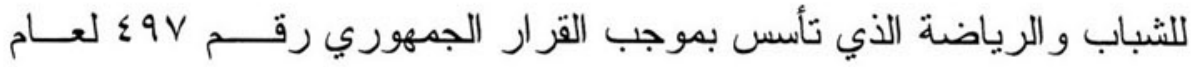

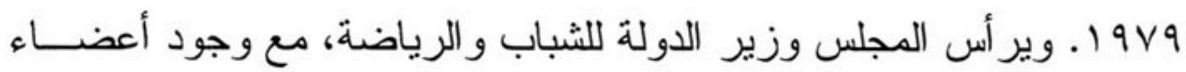
بالمجلس من عدد من الوزارات المعنية. يهذف هذا المجلس إلى تعزيز الحالة الصحية و النفسية و الاجتماعية للنشء و الثباب من خلال رياضــات وفنــون

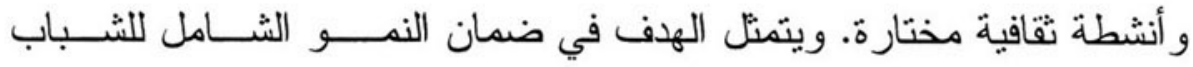
وترسيخ القيم الدينية وغرس السلوك الاجتماعي اللائق من خلال اســـــــدام وقت الفر اغ و القدر ات الخلاقة بطريقة تعود بالفائدة على الشباب و المجتمع.

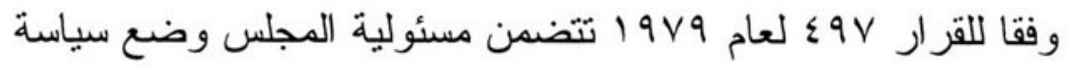

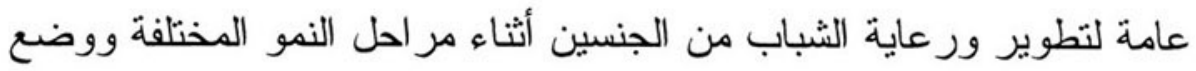
الخطط لتنفيذ هذه السياسات، وتتسيق البرامج ضمن هذا الإطار العام بما في

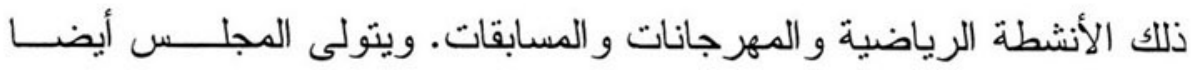


مسئولية تمويل هذه الأنشطة على المستويين القومي و المحلي ووضع خطوط

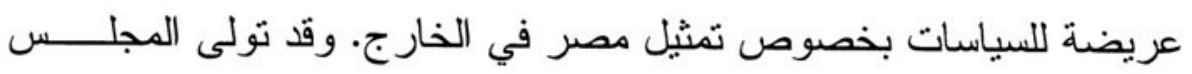

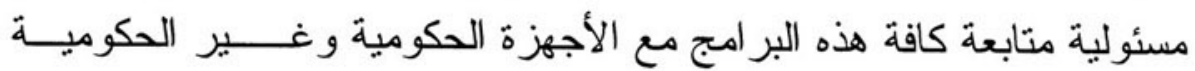

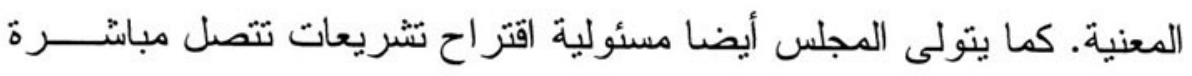
بالشباب و إعداد الجو ائز و الحو افز للشباب في المجالات التي يعمل بها.

قام المجلس منذ تأسيسه بتطوير مجموعة واسعة من البر امج تعنــى لى

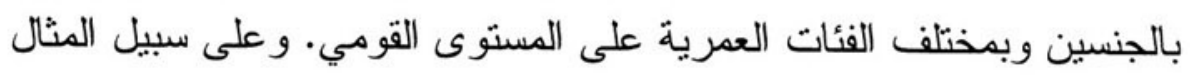

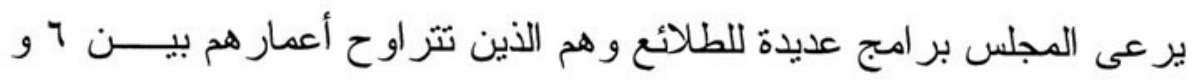

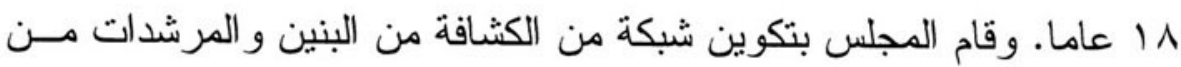

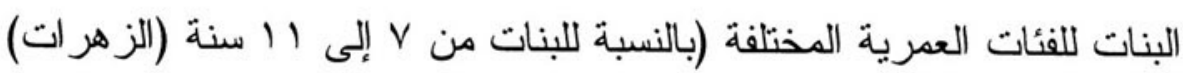

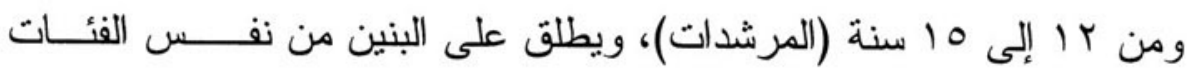

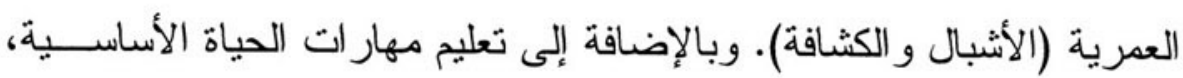

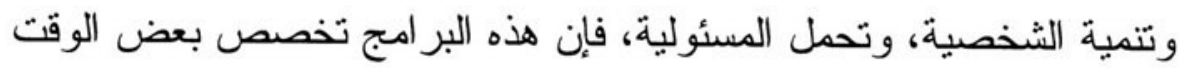

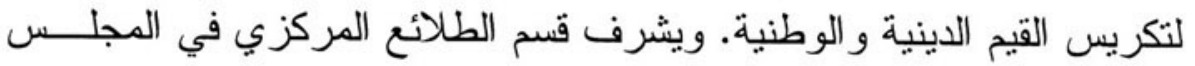

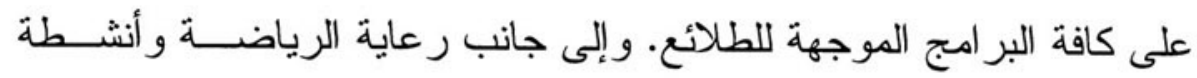

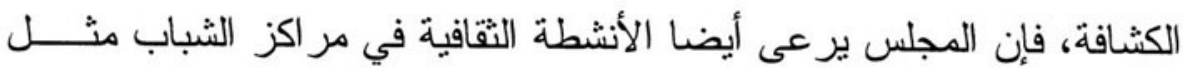
الموسيقى و الفرق الغنائية و الفنون و المسر ح و الرقص الشعبي. وينظم المجلس أيضا مسابقات رياضية في مر اكز الشباب في مختلف

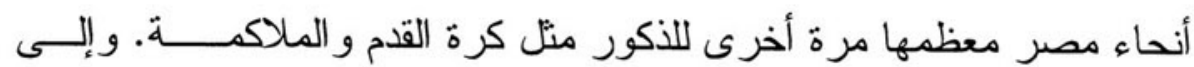

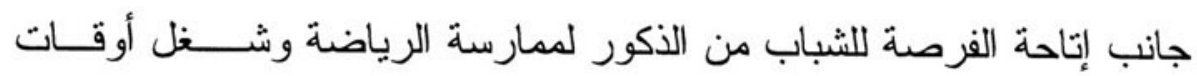

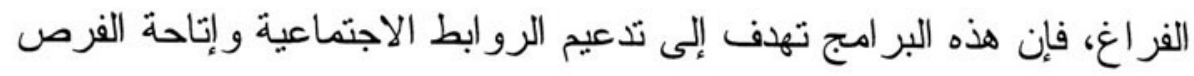
للشباب من الذكور لزيارة المحافظات الأخرى. 
"الرياضة للجميع" برنامج آخر ير عاه المجلس. بدأ هذا البرنامج فــي

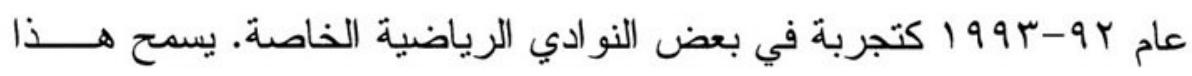

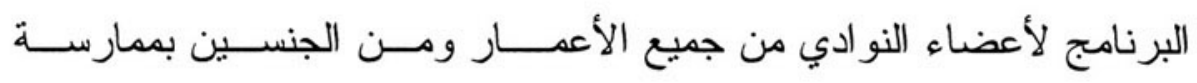

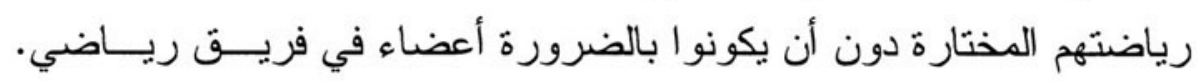

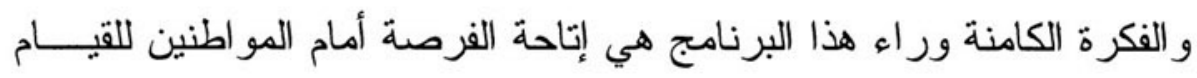

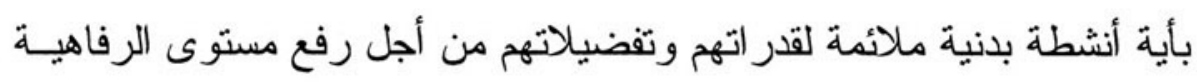

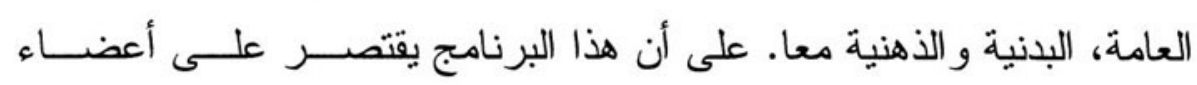
النو ادي. وقد شارك في هذا البرنامج ثلاثون ناد على مستوى الجمهورية في . $199 \varepsilon-94$

في مسعى لإدخال الرياضة إلى عالم المر اهقين ذوي الدخل المحـدود

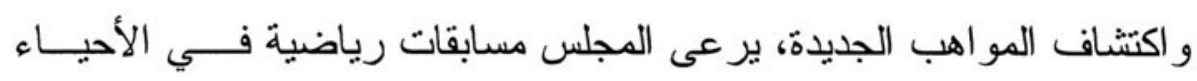

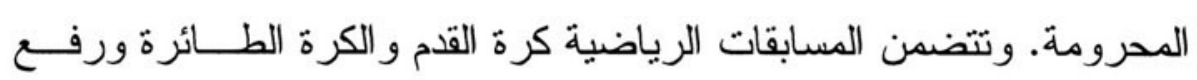

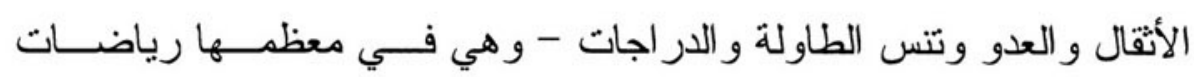

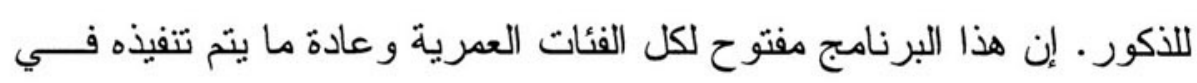
الساحات العامة بالمحافظات.

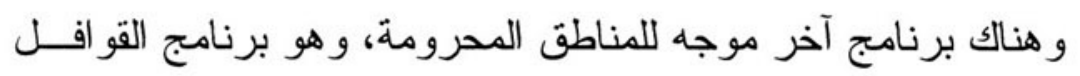

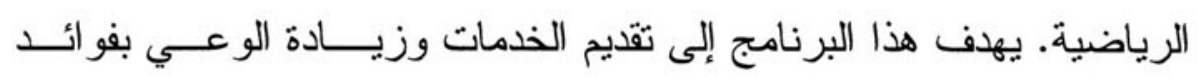

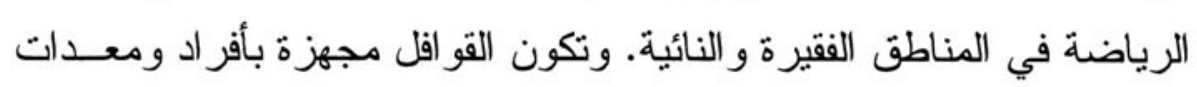

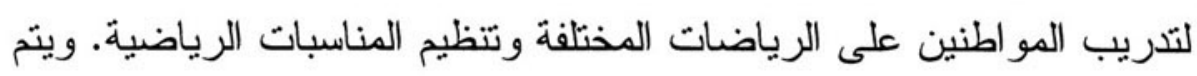
تطبيق هذا البرنامج أيضا في الساحات العامة و الددائق وفي ضواتئي الرئي المدن.

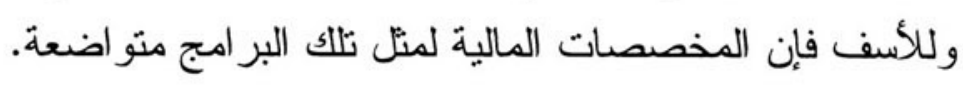


وبالرغم من كل هذه الجهود لنشر الرياضة فإن هنالك إجماعا عامـ

على أن الاستثمار في البنية التحتية و التجهيزات الرياضيــــة كــان منــــاز ا للمر اكز الحضرية الكبرى. وبالإضافة إلى ذلك، فإن المعاقين، وخاصة فــي المحافظات الفقيرة، محرومون من ممارسة الرياضة و الأنشــــة الترويحيــة

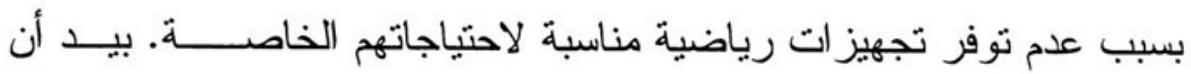
المجلس مهنم بتحقيق مزيد من العدالة في توزيع الفرص. وقـــــ خصصـــ

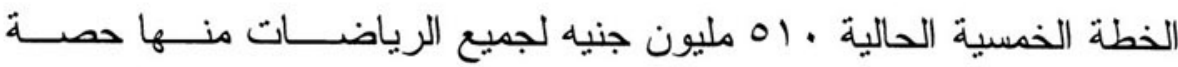
لتأسيس خمسة أندية للمعاقين وخمسة أندية أخرى للشباب المو هوب من ذوي المهار ات الخاصة على امتذاد البلاد.

\section{محاربة الاستخدام الهدام لوقت الفراغ}

يمكن تعريف الاستخدام الهدام لوقت الفراغ بأنه أي عمل أو نشــــاط

لتمضية الوقت يعرض صاحبه و المجتمع للخطر أو الضـــرر • وكثـيرا أهــا يشتمل ذلك على أفعال مخالفة للمعايير الاجتماعية للسلوك المقبول. وتمثـــلـ تلك الأفعال سلوكا منحرفا من جانب المر اهقين الذين يشــــار إليـــهم عــادة

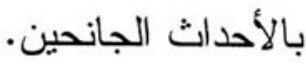

في السياق المصري، يستخدم لفظ "الحدث" للإشـارة إلـــى الأحــداث الجانحين. ورغم أن هذا اللفظ لا يشير من الناحية اللغوية سوى لحداثة السن، إلا أنه صار يرتبط بالسلوك الجانح. ومن الجدير بالذكر أن مصر كانت مـن أو ائل الدول التي تعاملت مع قضية جنوح الأحداث. صدر النشريع الأول في

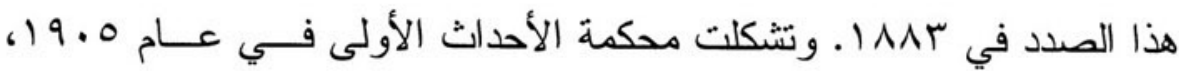
و هي الثانية في العالم بعد تلك التي تأسست في بريطانيا. وتأسس أول مركـز

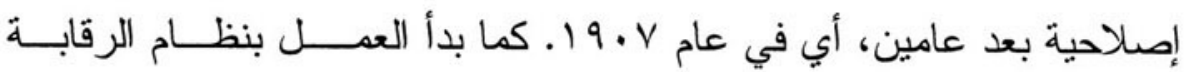


الاجتماعية في عام • \9 19، في حين تأسست أول مؤسسة رقابية في 19 19

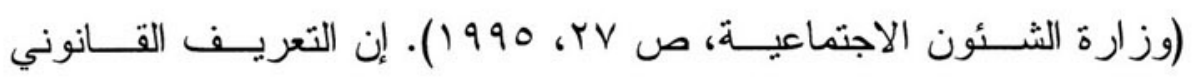

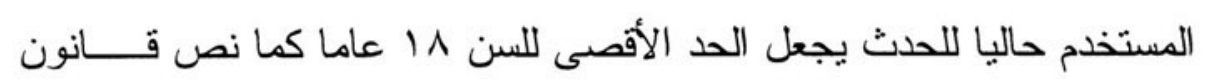

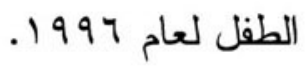

و على الرغم من أنه لا تتو افر إحصـاءات منظمـــــة للأحــــاث فــإن

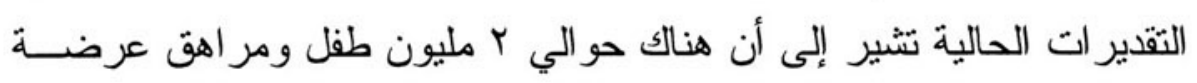

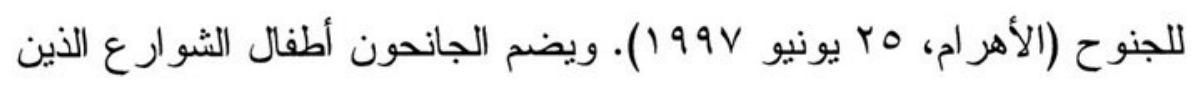

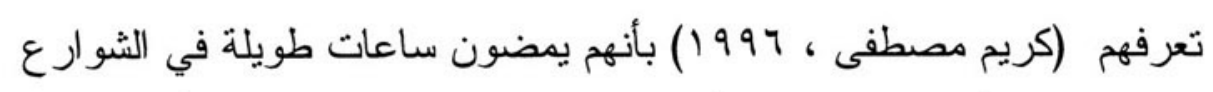

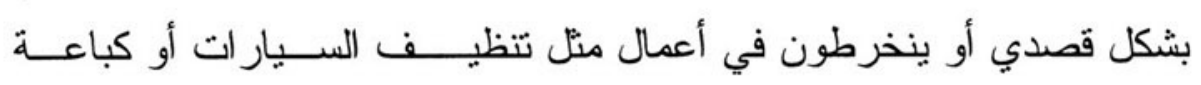

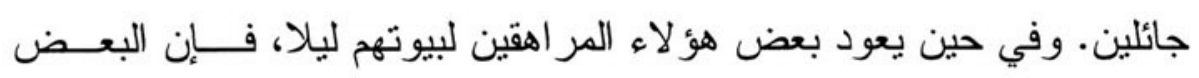

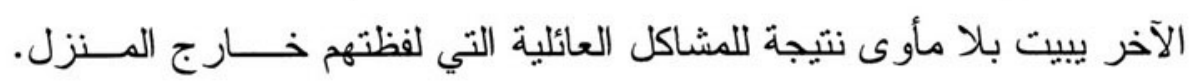
وتتضمن أنواع الجنوح الأخرى تجارة المخدر ات و التخريب و الدعارة.

إن أسباب السلوك الجانح كانت لأمد بعيد موضو عا لدر اسة علمــــــاء

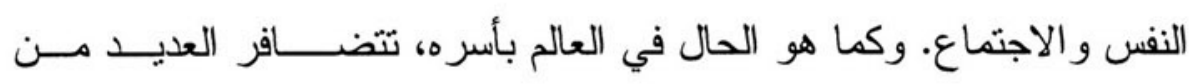

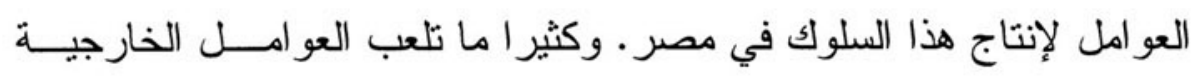

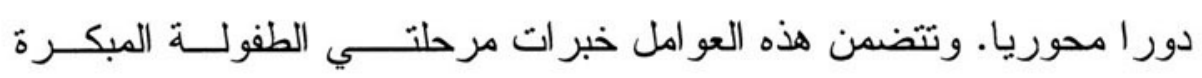

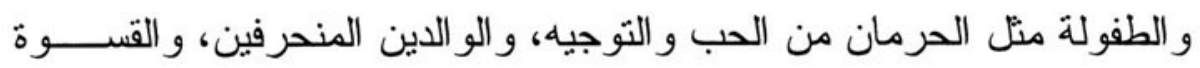

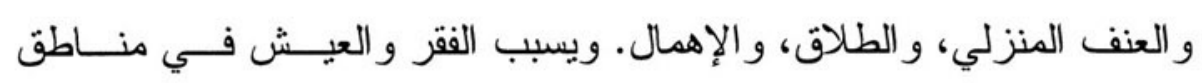

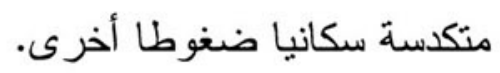
سياسة الدولة والإطار التثريعي

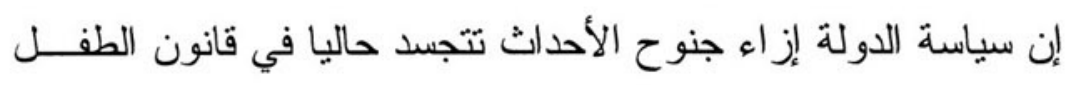

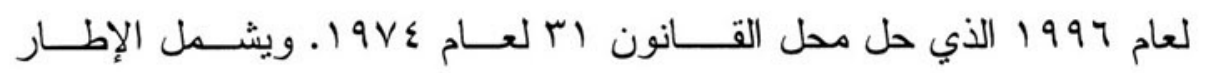


المؤسسي الحالي لجنوح الأحداث ثلاث وزارات أساسية هي الداخلية و العـدل

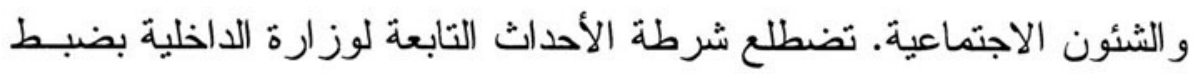

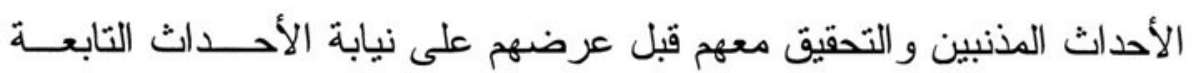

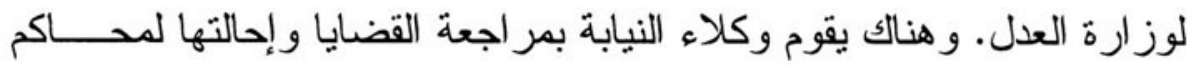

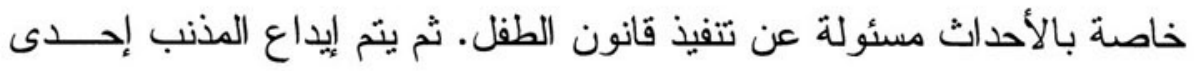

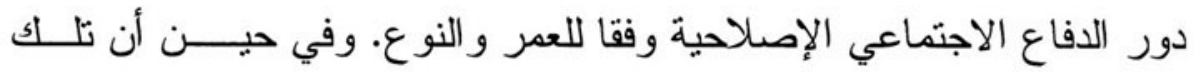

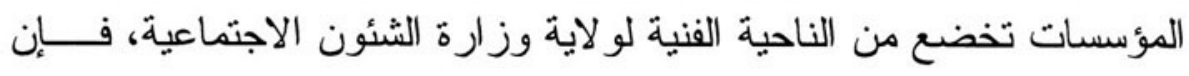
الإشر اف عليها يتم بالتعاون مع وزارة الداخلية.

وفقا للمسئولين في وزارة الشئون الاجتماعية فإن أحد أهم التعديـلات

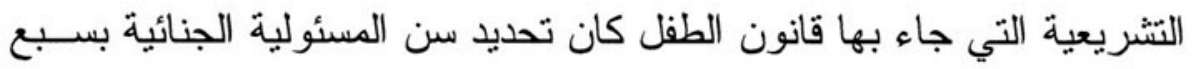

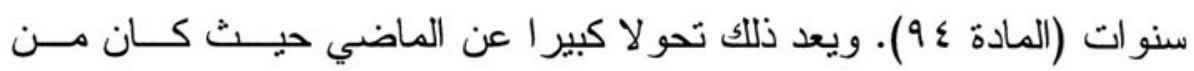

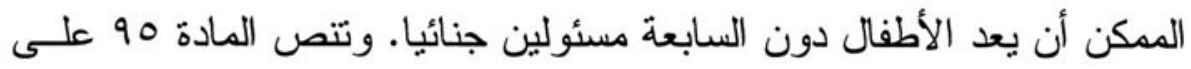

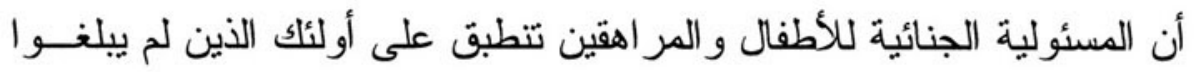

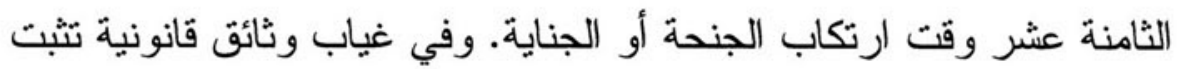
سن المذنب يتعين على المختصين تقدير العمر.

ووفقا للمادة 97 يعتبر المر اهق جانحا إذا انخرط في أنشــــة مثــلـ

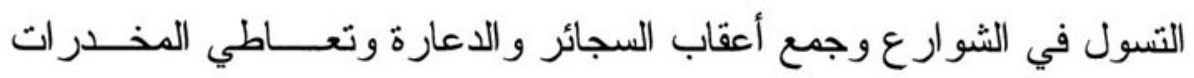

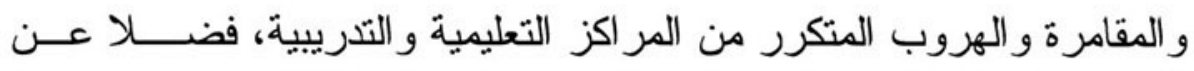

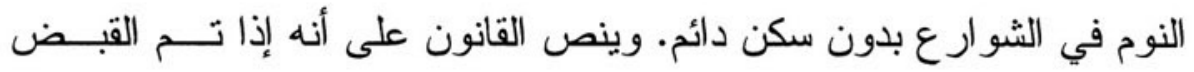

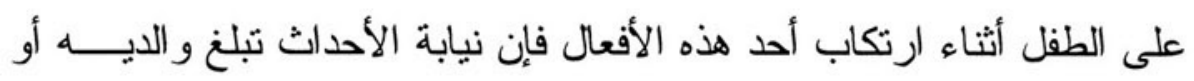

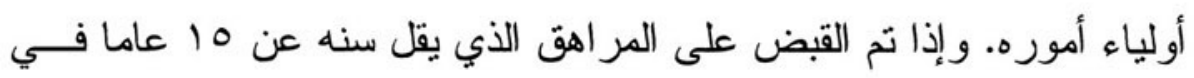

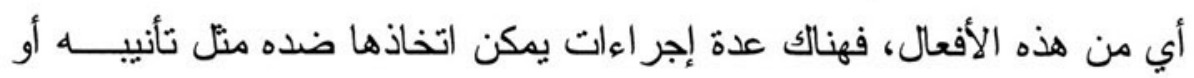


إثر اكه في بعض الأعمال التدريبية أو المنتجة أو مهام إلز امية أخرى مثـــلـ

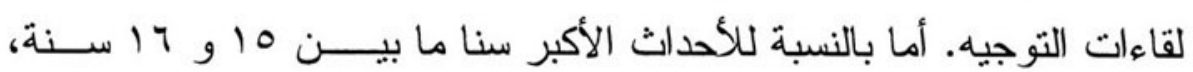

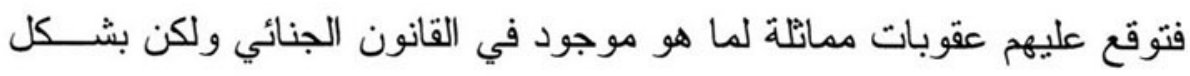

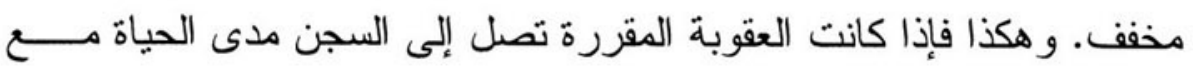
الأشغال الشاقة فإنه يتم استبدالها بعقوبة سجن مخففة. وتثشدد العقوبة بالنسـبـة

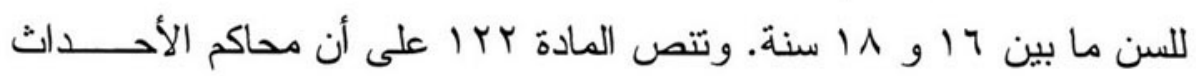

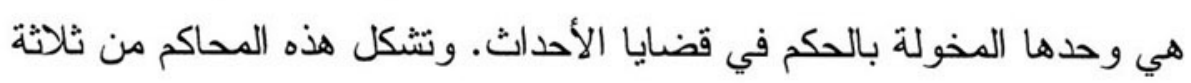

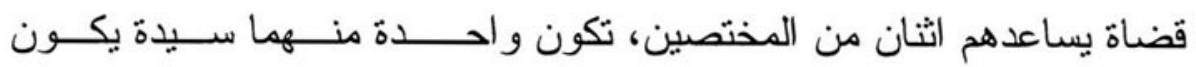
حضور ها إجباريا. إلا أن هنالك بعض القضايا التي يتعين النظر فئــــا أمــام المحكمة الجنائية أو محكمة أمن الدولة.

وتبعا لعمر الذكر الدذنب وطبيعة الجريمة المرتكبة فإنه يمكن إيداعه

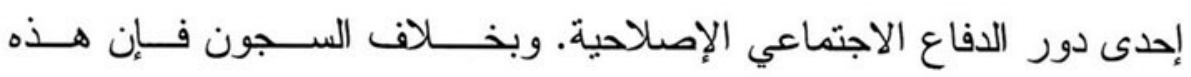

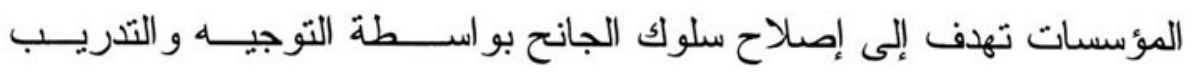

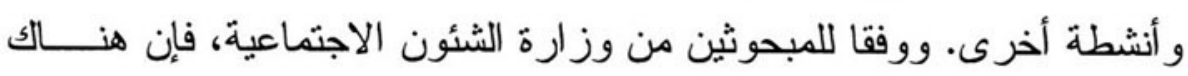
حاليا ثلاثة أنو اع من هذه المؤسسات تختص بفئات عمرية مختلفة. أو لا، هناك مؤسسات "الباب المفتوح" التي تستو عب الأشبال من سـن

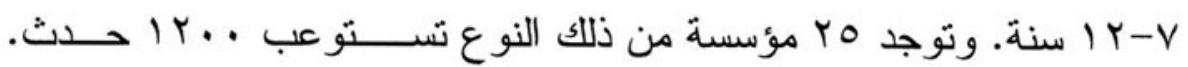

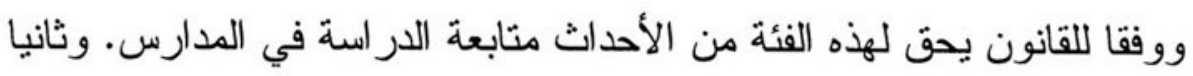

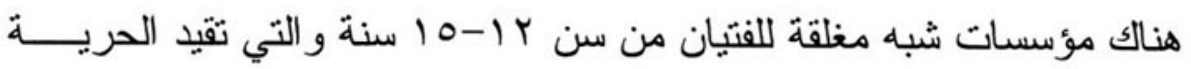

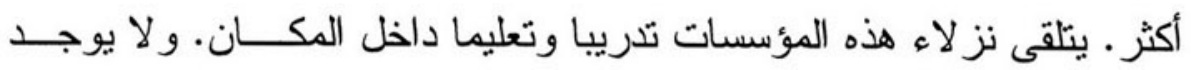
حاليا إلا مؤسستان من هذا النوع على مستوى الجمهورية، واحدة في القاهرة

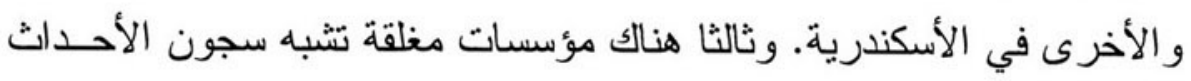


وتضم الثباب في سن 10-11 سنة الذين فرضت عليهم عقوبــات نتطلــب

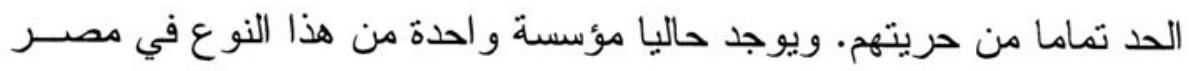

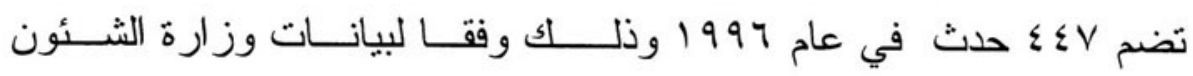

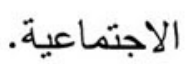

أما المر اهقات الأحداث اللاتي يشار إليهن بالفتيات القاصر ات، فيتــم

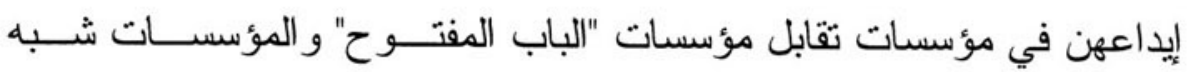
المغلقة الخاصة بالذكور ـ. وتضم المؤسسات شبه المغلقة فتيــات تعديــن 10

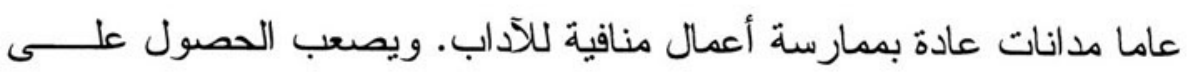

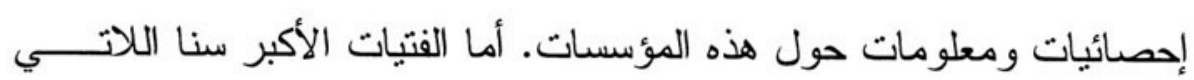

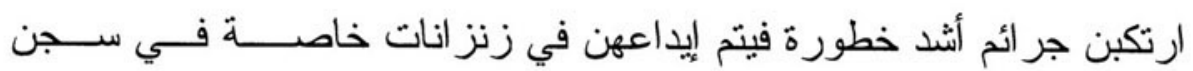
القناطر للنساء حيث أنه لا توجد مؤسسات مغلقة للفتيات.

التحديات

$$
\text { عدم المساواة في توزيع التجهيزات الرياضية }
$$

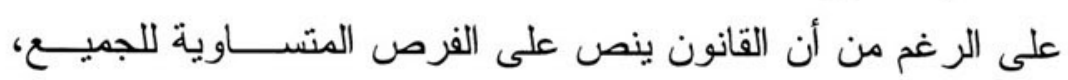

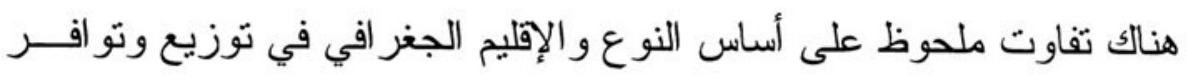

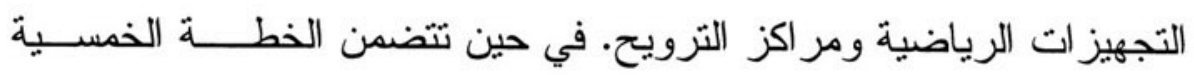

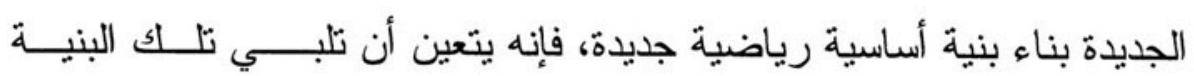

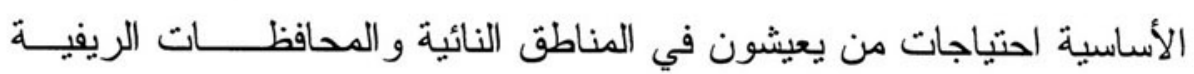

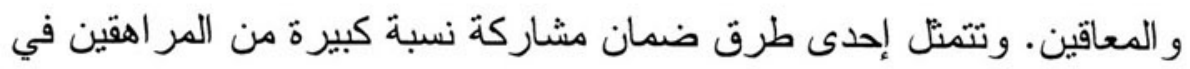

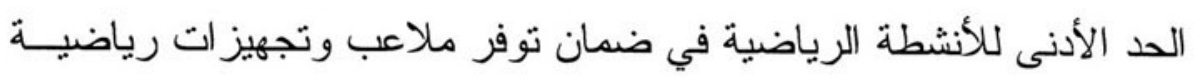

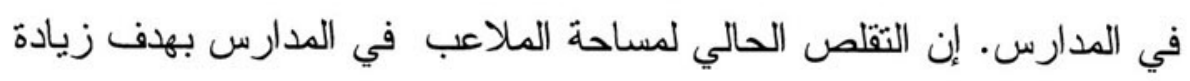
عدد الفصول لا يمكنه إلا أن يخلق جيلا من الشباب القاصر عوضا لئا عن أفراد الدي 
مكتملي الشخصية. و هناك حاجة لعناية خاصة بتوفير خدمات وقـــت فــر اغ للفتيات نكون مقبولة في المجتمعات التي يعشن فيها. استغالل المر/هقين في أنشطة /إجرامية

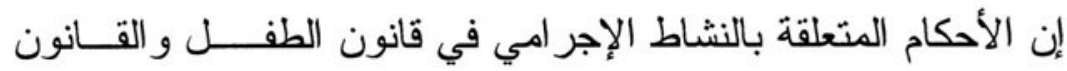

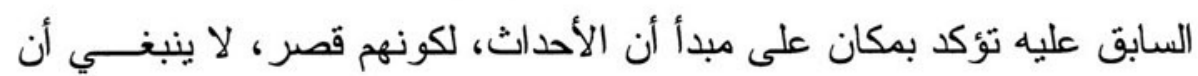

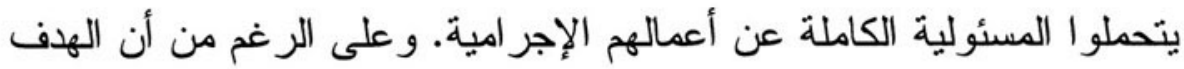

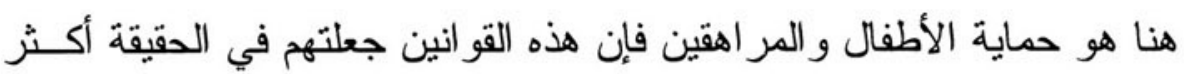

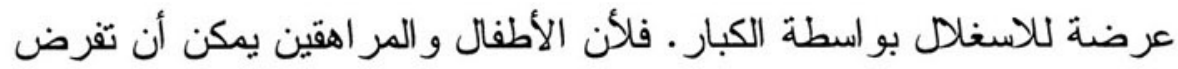

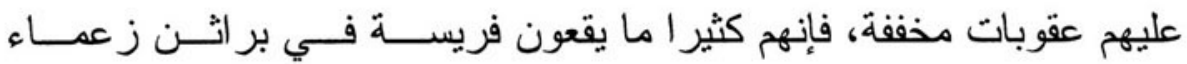

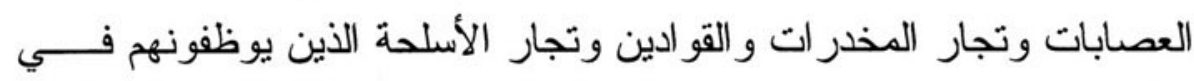
الأعمال غير المشروعة. ويرى المراقبون أن تلك القضية تحتاج لعناية أكبر الكبر من جانب وز ارني الداخلية و العدل. حالة مؤسسات الدفاع الاجتماعي إن حالة مؤسسات إصلاح الأحداث و إعادة تأهيلهم غير مرضية بكل المقاييس. ووفقا لبعض الثقارير فإن ظروف الحياة بها مزرية. لا تعاني هــــه

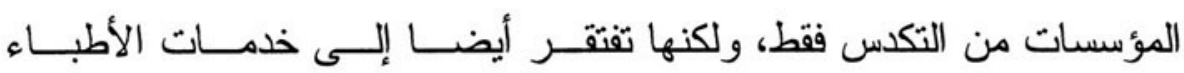
و الإخصائيين الاجتماعيين الددربين و المتخصصين. و إذا كانت وزارة الشئون الاجتماعية قد خصصت · r مليون جنيه لتجديد المر اكز القديمة وبناء مر اكز

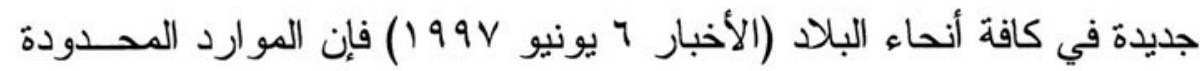

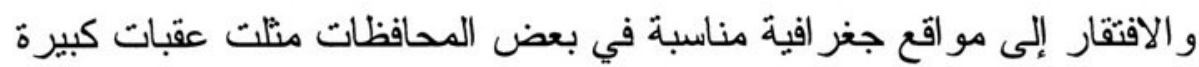

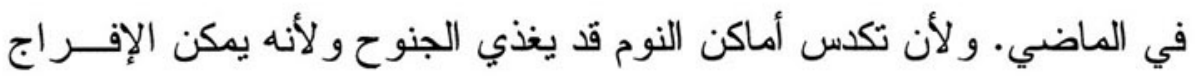


عن الأحداث بسبب التكدس، فإنه يتعين تقييم حالة المؤسسات الر اهنـــة مـــع اتخاذ الإجر اءات النصويبية اللازمة.

$$
\text { محاربة جنور الجنوح }
$$

في ضوء زيادة معدلات جنوح الأحداث، فإن أحد مشاغل الدولة على

المدى الطويل هو مو اجهة جذور هذه الظاهرة. إن هذا أمر حيــوي بســبـ التكاليف الباهظة التي تنكبدها الدولة في حفظ الأمن و السلام الداخلي و إعـادة

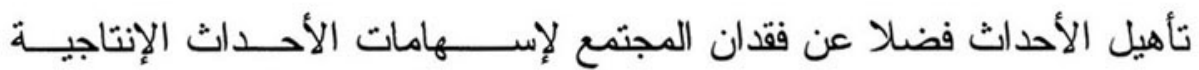

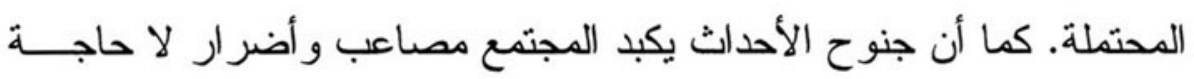
لها. ويقوض الأحداث أنفسهم فرصهم في إكمال حد أدنى من التعليم بســبب

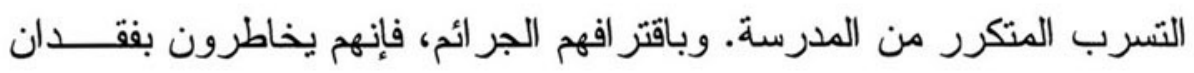
فرصتهم في حياة حرة آمنة ومنتجة ككبار ـ هناك الكثير الذي يجــب عملــــ للقضاء على الفقر وندرة الفرص وشروط الحياة المزرية التي نشكل الأرض حره

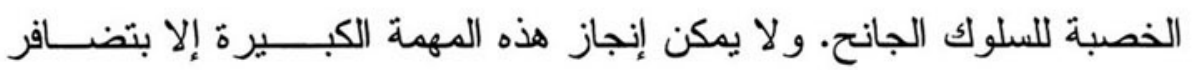
جهود الدولة و القطاع الخاص و المجتمع المدني. 


\section{النتائج و التوصيات}

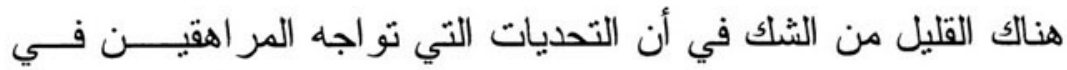

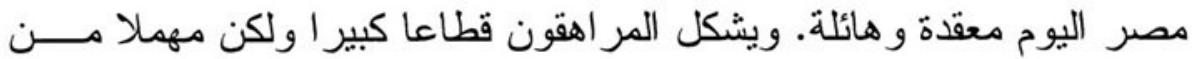

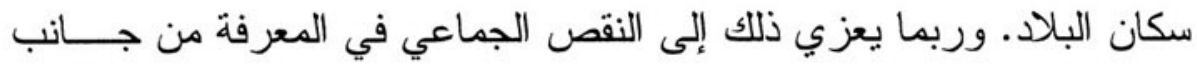

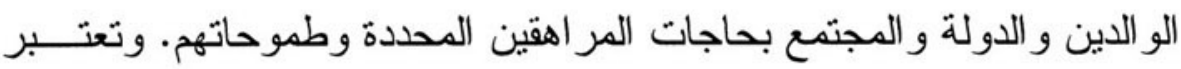

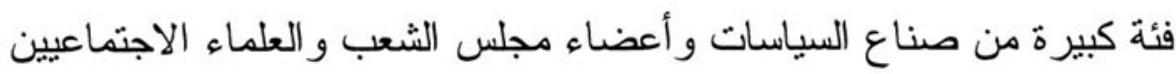
و المثققين أن المر اهقة منطقة مبهمة لا يتوفر لها تعريف مقبول بشكل عــام. و إلى جانب قانون الطفل الصادر عام 1997 و الذي يعرف كل من هــم دون سن 1^ا عاما بأنهم أطفال دون تمييز محدد لمرحلة المر اهقة، فإن الـــــيئات

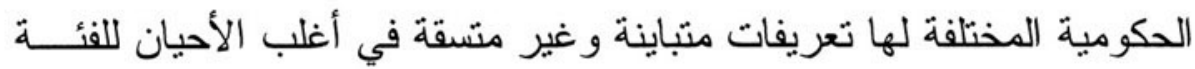
العريضة التي تتر اوح بين ـ 1-9 19 عاما.

وبينما خدمت العديد من التعريفات الإجر ائية الغرض من اســتهداف

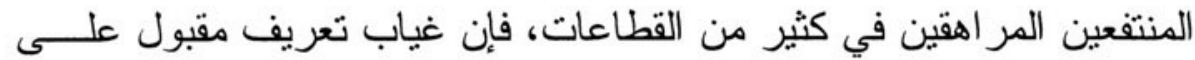

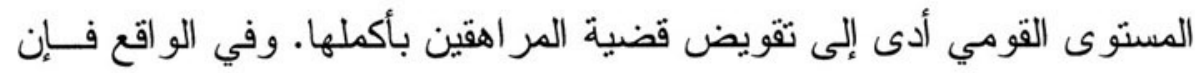
الحاجات الخاصة للمر اهقين تبدو ضائعة وسط القلق الرســـي الثــديد إزاء

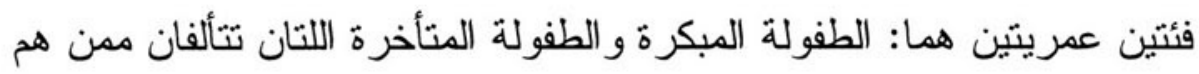

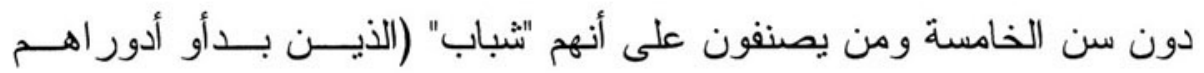
كبالغين في العمل و الإنتاج).

ونظر الأن الاحتياجات و المشاكل و التحديات التي تو اجه المر اهقين لا

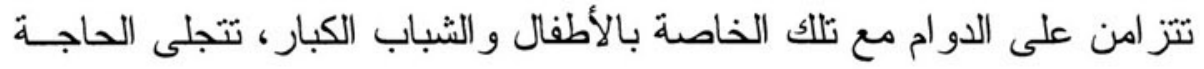

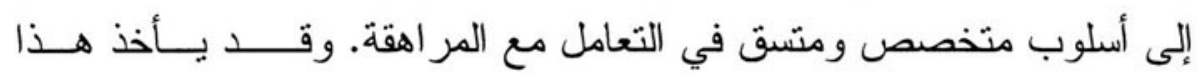

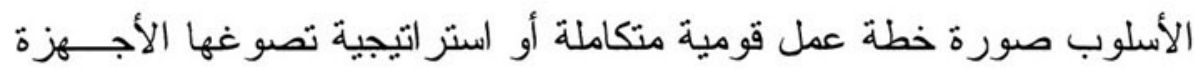


الحكومية المعنية. وبالإمكان تكليف لجنة وز ارية تشارك فيها جميع الجــهات

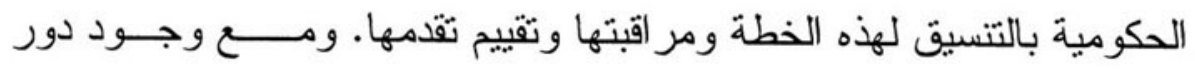

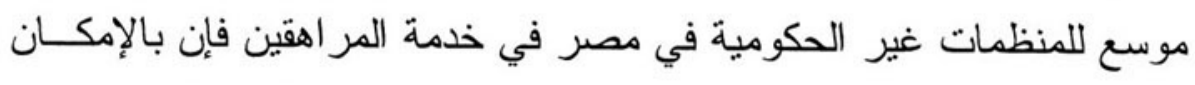

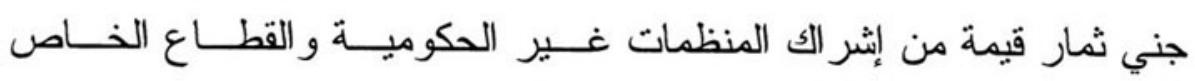
و المجتمع المدني في هذه المبادرة.

ولحسن الحظ تعمل كثير من المؤسسات في هذا المجال. ويتعــرض

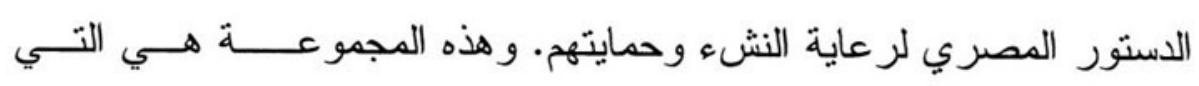

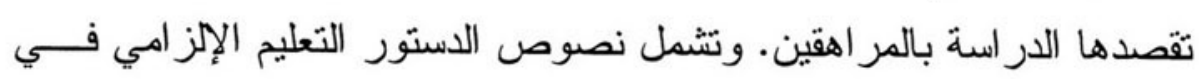

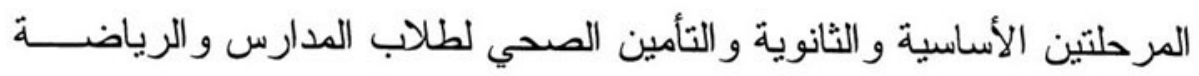
ومر افق الترويح. و هناك العديد من القوانين التي تحمي المر اهقين من أخطار

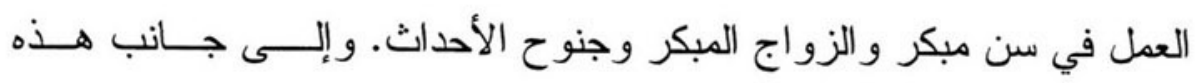

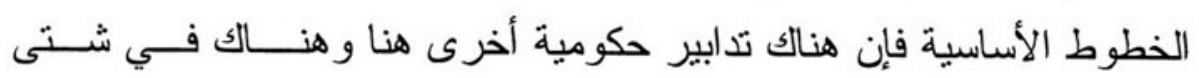

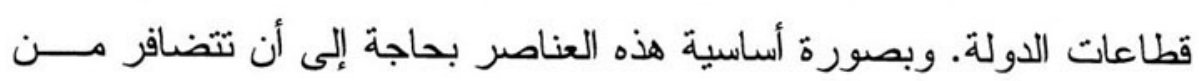

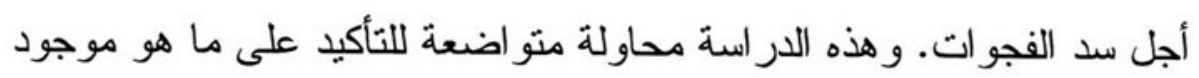

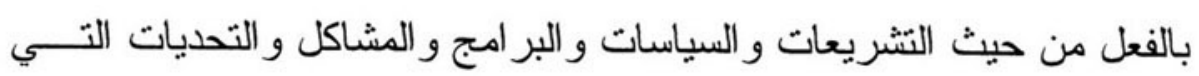
تحتاج إلى اهتمام تشند الحاجة له من جانب الدولة.

ومن بين المكونات الأكـــثر حيويــة بالنســـة لنجـــاح الخطـــة أو

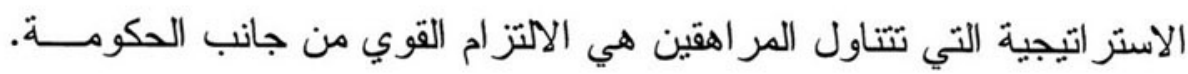

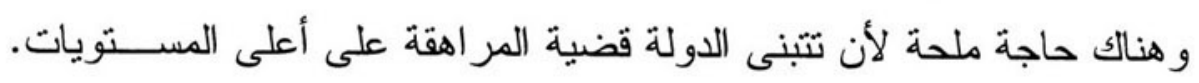

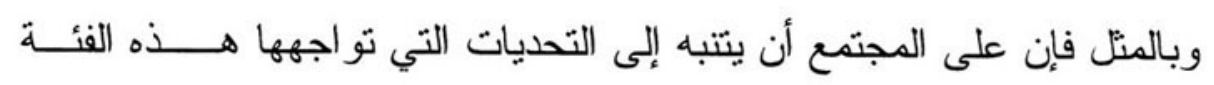
العمرية اليوم و الشروع في تتاول هذه القضايا. 
وتبين الدر اسة بما لا يدع مجالا للثك أن المشاكل و التحديات التــي

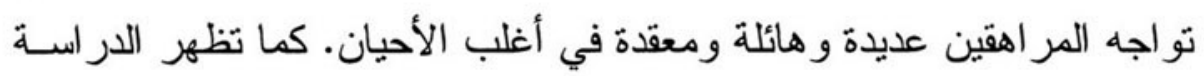

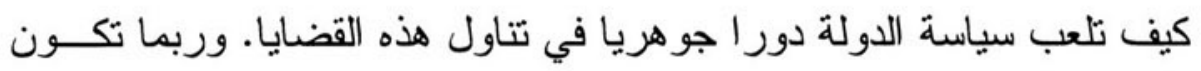

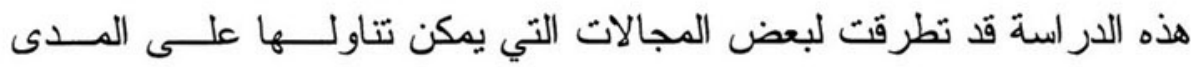

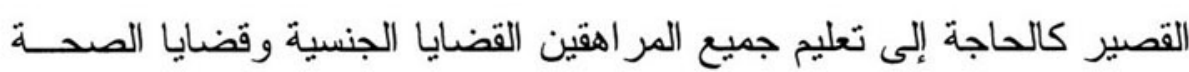

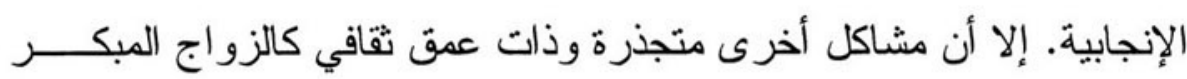
للمر اهقات وممارسة ختان الاناث سنتطلب جهودا أكبر .

وعلاوة على ذلك فإن هناك دلائل على أن الفروق في النوع و الخلفية

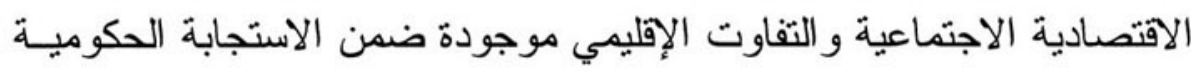

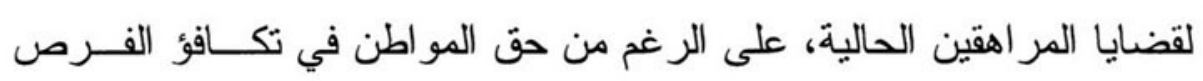

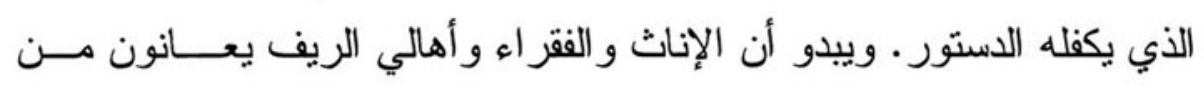

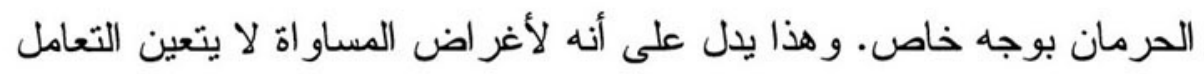

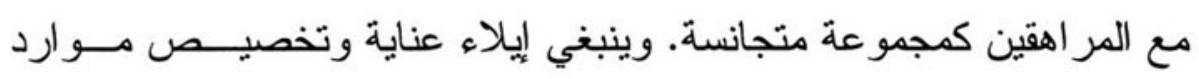
للفئات الفرعية التي لا نتمتع بمز ايا بين الثباب. و لا يتعين إساءة تقدير حجم الموارد والإطار الزمني اللازمين لتتاول

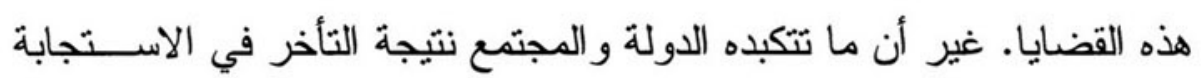

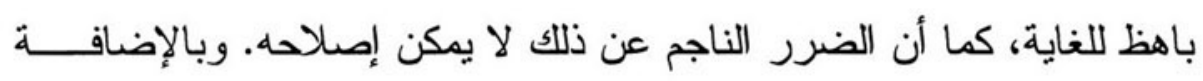

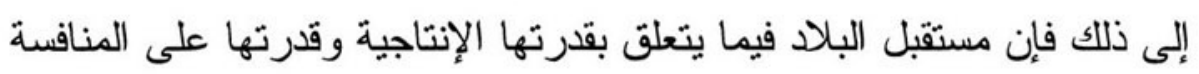

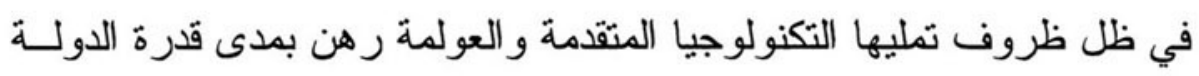

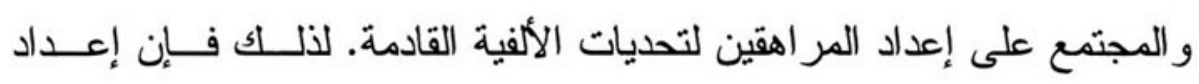

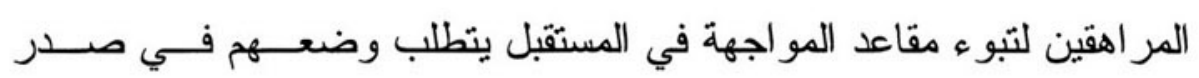
أولويات جدول أعمال الدولة اليوم. 


\section{المراجع باللغة الاتجليزية}

Cairo Times. 1997. Why the Rush to Conceive? p 7. 13-26 November.

El-Hamamsy, Laila. 1994. Early Marriage and Reproduction in Two Egyptian Villages. Occasional Monograph. The Population Council / UNFPA, Cairo.

1995. Conceptual Framework for the Study of Adolescent Girls in Egypt. The Population Council, Cairo. (Unpublished).

El-Zanaty, Fatma and others. 1996. Egypt Demographic and Health Survey 1995. National Population Council, Egypt. Macro International Inc. Maryland.

Fergany, Nader and others. July 1996. Enrollment in Primary Education and Cognitive Achievement in Egypt, Change and Determinants.

Institute of National Planning. 1995. Egypt Human Development Report.

Institute of National Planning. 1996. Egypt Human Development Report.

Karim, Mahmoud. 1998. Female Genital Mutilation (Circumcision): Historical, Social, Religious, Sexual and Legal Aspects. (Illustrated) National Population Council.

Levinger, Beryl. 1994. Nutrition, Health and Education for All. EDC and UNDP.

Ministry of Education. 1993. Education for All in Egypt. Report presented at the Nine-Country EFA Meetings, Cairo.

Ministry of Education. 1995/1996. Pre-university Education Statistics.

Ministry of Social Affairs. 1984-1994. Achievements of the Ministry of Social Affairs in Ten Years.

Moghadam, Valentine ed. 1995. Economic Reports, Women's Employment and Social Policies. World Development Studies 4. UNU World Institute for Development Economics Research.

Mubarak and Education: A look at the Future.

National Center for Social and Criminological Research \& the United Nations Children's Fund. (UNICEF). October 1989. Report of the International Committee on Child Labor in Egypt.

National Population Council. 1998. Scientific Programme Towards Better Reproductive and Sexual Health: Pathways for Action. Report of the Expert Meeting 14-19 February. Cairo.

Population Council. 1996. Clinic-based Investigation of the Typology and Selfreporting of FGM in Egypt Final Report, Cairo.

Selim, Samy. 1996. Children and Women in Egypt: An Information Atlas. National Council for Childhood and Motherhood. 
Senderowitz, Judith. 1995. Adolescent Health: Reassessing the Passage to Adulthood. World Bank Discussion Report 272. The World Bank, Washington, D.C.

Sohoni, Neera. 1995. The Burden of Childhood. California: Third Party Publishing Company.

Spaulding, S. et al. 1996. Review and Assessment of Reform of Basic Education in Egypt. Report prepared for UNESCO and UNDP, Cairo.

UNESCO. 1995. The Education of Girls and Women: Towards a Global Framework for Action.

World Bank. august 1996. Education Enhancement Program. Staff Appraisal Report. Arab Republic of Egypt.

Zulficar, Mona. 1995. Women in Development: A Legal Study. UNICEF, Cairo 


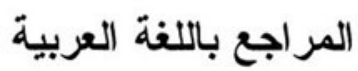

القانون رقم 9 ل لسنة 9 19 بشأن تأهيل المعوقين و لائحته التتفيذيـة

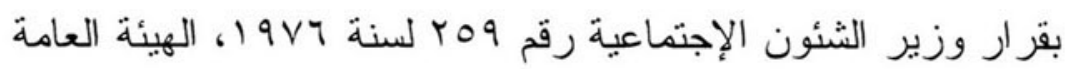
لشئون المطابع الأميرية، القاهرة: 1990.

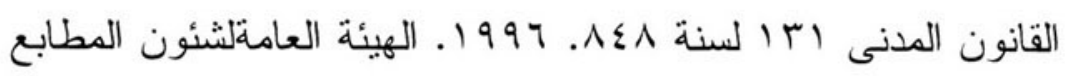

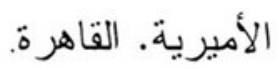

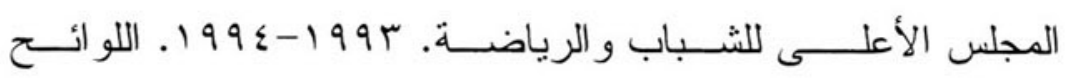
و التعليمات الخاصة لدورى الأحياء الشعبية و القو افل الرياضية.

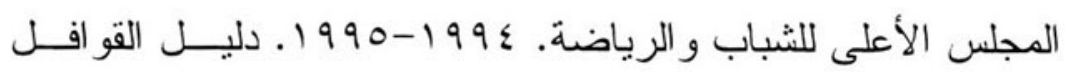

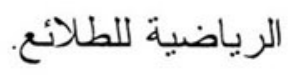
المجلس الأعلى للشباب و الرياضة. 1990-1999 19 ـليـــلـ العـــلـ للمشرو عات القومية المنفذة بالمحافظات. المجلس الأعلى للشباب و الرياضة. 997 1997 19 ـ قطاع الطلائسـع. دليل العمل للنشاط الثقافى للطلائع.

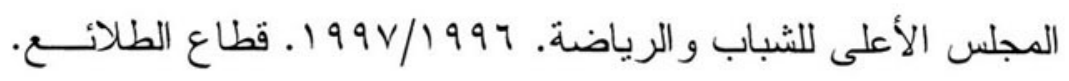

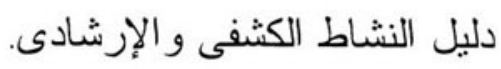

المجلس القومى لمكافحة وعلاج الإدمان. بو 199 أستر اتيجية قوميـة

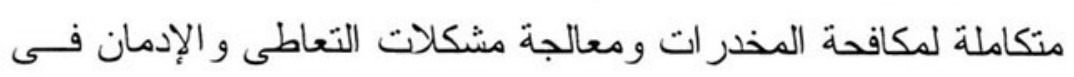
مصر . التقرير النهائى. القاهرة.

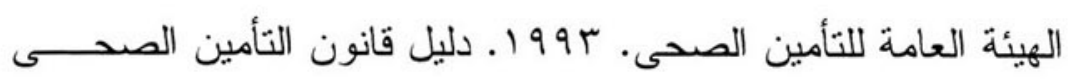
على الطلاب و القرار ات التنفيذية له، القاهرة. 
بشير ، حسين. 911 ــ "منهجية تقويم السياسة التعليمية" فى منهجيـة

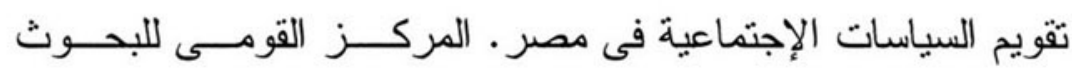
الإجنماعية و الجنائية، القاهرة.

جمهورية مصر العربية. 990 ـ. القانون رقم 9 ب لسنة 19 19 بشأن تأهيل المعوقين. الهيئة العامة لشئون المطابع الأميرية.

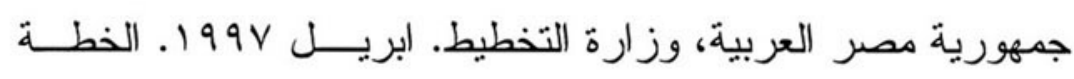

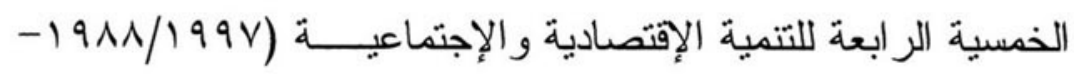

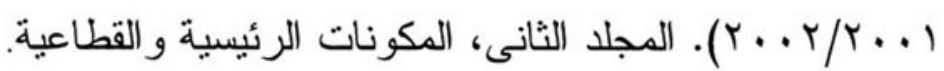
جمهورية مصر العربية. ع99 19. قانون الأحوال الشخصية للمسلمين

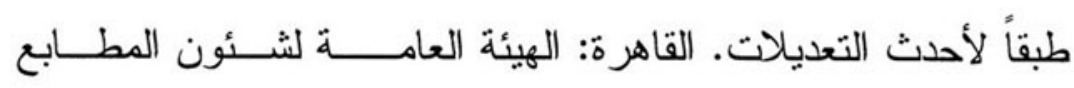

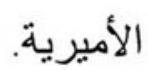

جمهورية مصر العربية. قانون التعليم العام.

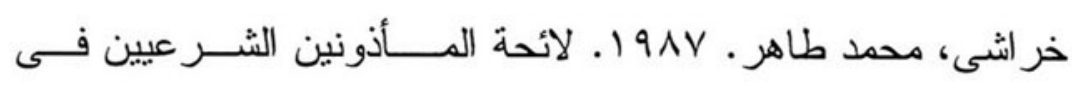

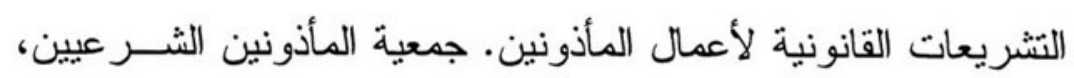

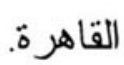

خلاف، عبد الغفار ـ 1911. . "تقويم السياسة الصحية فى مصر" فـى

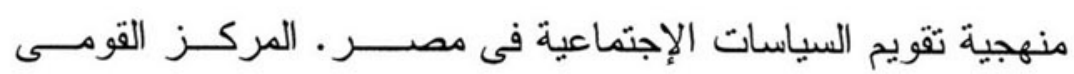
للبحوث الإجتماعية و الجنائية، القاهرة.

دستور جمهورية مصر العربية و القو انين الأساســـية المكملــة لــه. 1997 ـ الهيئة العامة لشئون المطابع الأميرية، القاهرة. 
عبد الموجود، عزت. 911 ـ "منهجية تقويم السياسة التعليمية" فـى

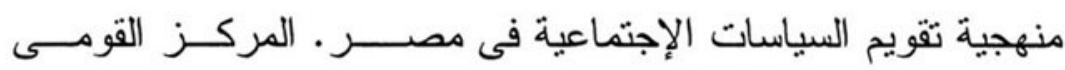
للبحوث الإجتماعية و الجنائية، القاهرة.

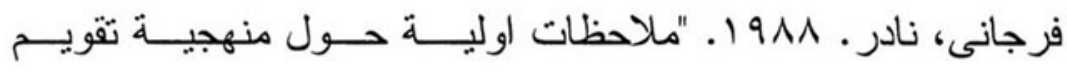
السياسات" فى منهجية تقويم السياسات الإجتماعية فى مصر ـ المركز القومى للبحوث الإجتماعية و الجنائية، القاهرة. قانون رقم r السنة 1997 بإصدار قانون الطفل. محرم، إير اهيم. 99 1 ـ شروق: التمية الريفية. مؤسسة دار التعاون

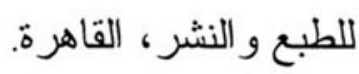
مصطفى، علا وعزة كريم. 1997 ( عمل الأطفال فـــى المنشــآت الصناعية الصغيرة. المركز القومى للبحوث الإجتماعية و الجنائيــــة،

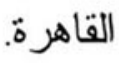

همام، عادل. النص الكامل لقانون العمل الجديد (VT السنة (9191).

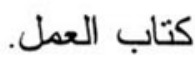

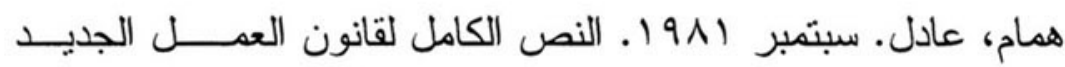

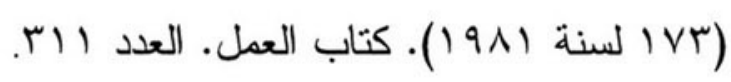
وزارة الإدارة المحلية، جهاز بناء وتتمية القرية المصريـــة. يوليــو 1999 ألبرنامج القومى للتنمية الريفية المنكاملة "شروق."

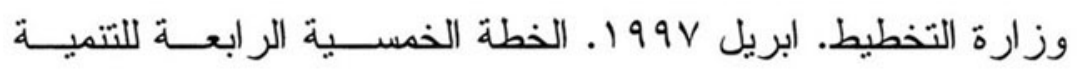

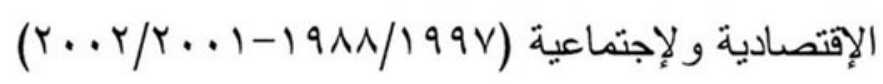


وز ارة الشئون الإجتماعية. سبتمبر 990 ـ برنامج مبارك للتكــــافل

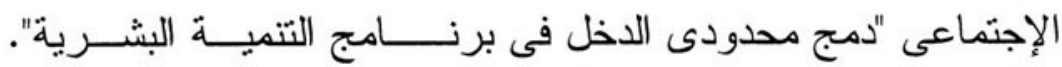

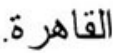

وزارة الشئون الإجتماعية، الإدارة العامة للدفاع الإجتماعى. 1990.

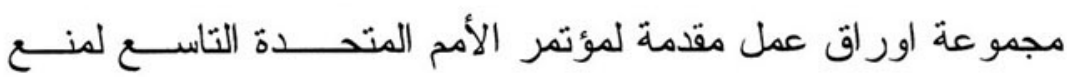
الجريمة ومعاملة المجرمين. القاهرة.

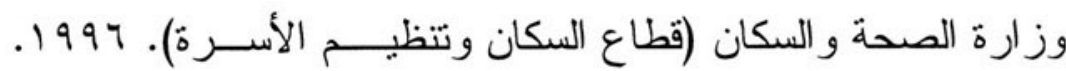
استر اتيجية وز ارة الصحة و السكان فــى نتفيــــ السياســة الســكانية

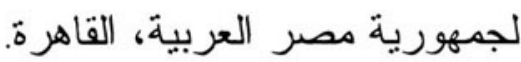

وز ارة الصحة و السكان. (1991 (1997). البرنامج الوطنى للصحة النفسية فى مصر. 


\section{ملحق رقم $1:$ دليل المقابلات}

(1) كيف تعرف الفئة العمرية . 1-19 سنة من منظورك الشخصى و كيف تصفها؟ r) ما هو التعداد التقريبى لهذه الفئة وما هى المائوية التى تمتلها هذه الفئة بالنسبة للتعداد الكلى؟ هو الكعاب r) ما هى احتياجات أو مشاكل أو تحديات هذه الفئة العمرية؟

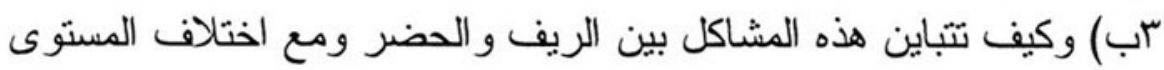
الاجتماعى و الاقتصادى؟ وكيف تقارن هده المشاكل بمشاكل الجيل السابق؟ لهاب

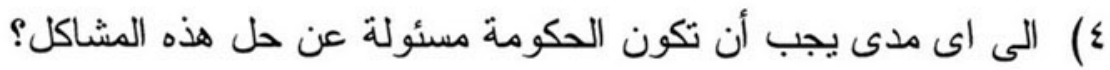

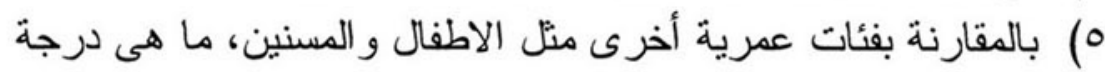

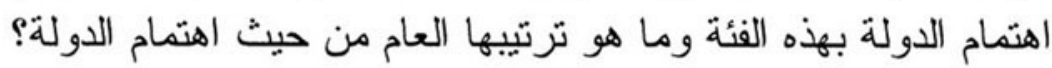

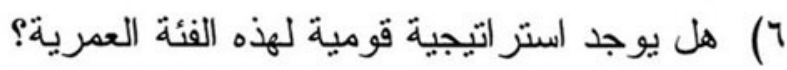

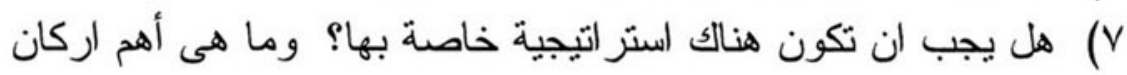
هذه الاستر اتيجية فى رأيكم؟ هاب هن هن

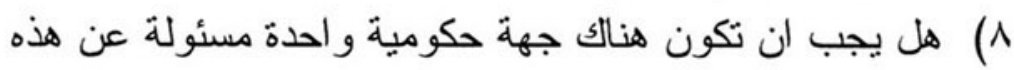
الاستر اتيجية؟

9) كيف تصف العلاقة الحالية بين الدولة وهذه الفئة العمرية؟

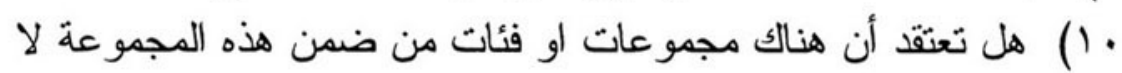

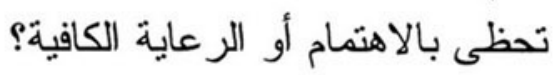
(1) (1) بالاضافة الى الدولة، على من نقع مسئولية هذه الفئة من حيث الرعاية و الاهنمام؟ r I (1) ما هو دور او طبيعة عمل او انشطة هذه الجهة / الوحدة ؟ ومنى بدأت اعمالها؟ r ا) ما هى الفئات العمرية التى تحظى باهنمامكم؟

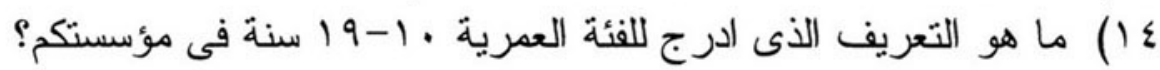
10) هل هناك اى جهات حكومية او غير حكومية تقوم بأنشطة تستهدف

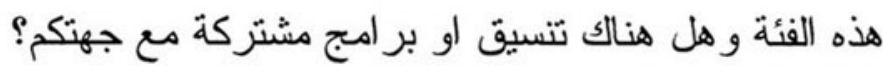




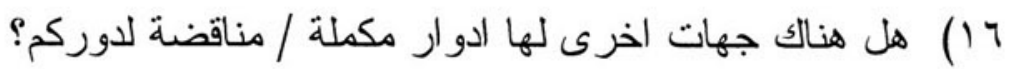

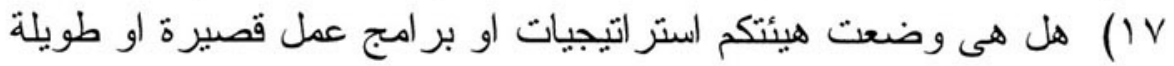

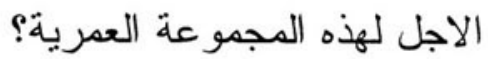

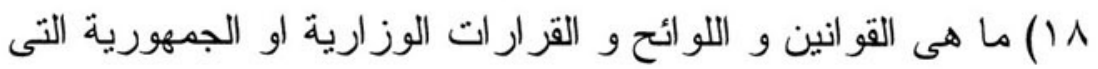

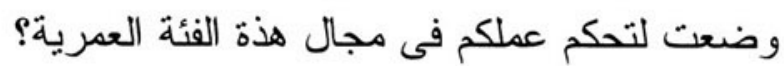

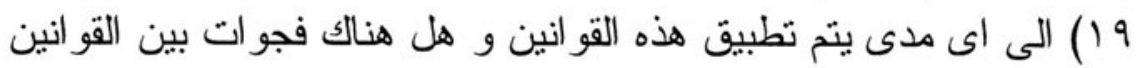

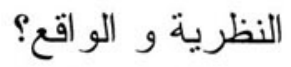

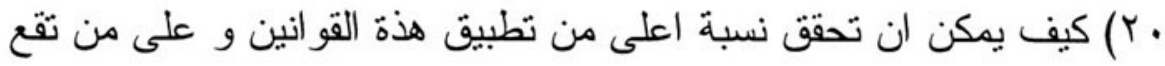

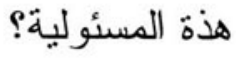

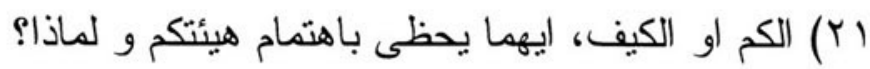

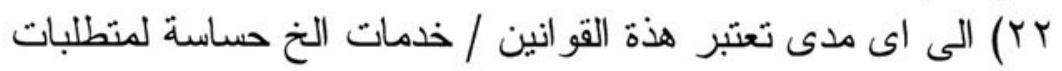

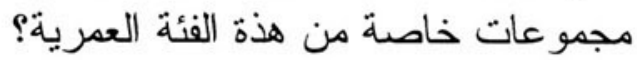

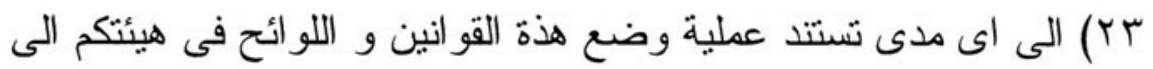

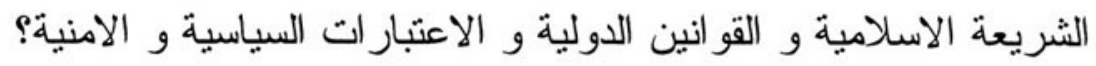

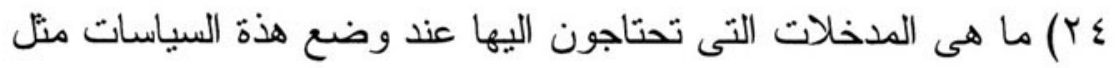

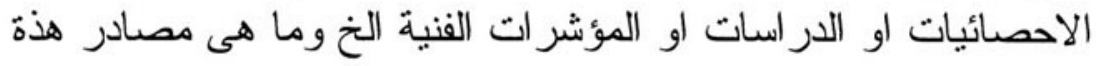

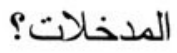

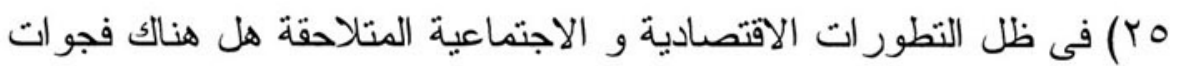

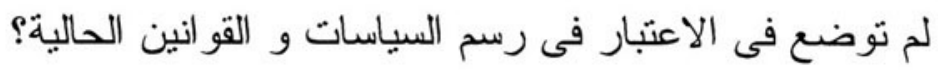

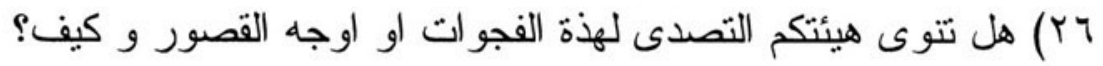

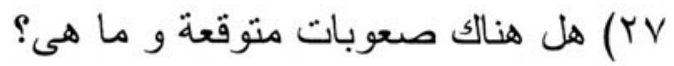

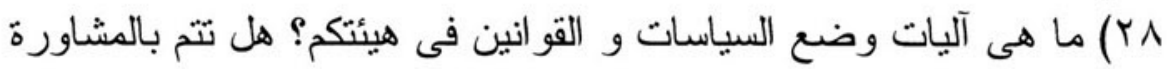

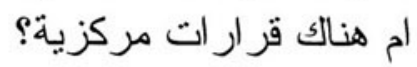

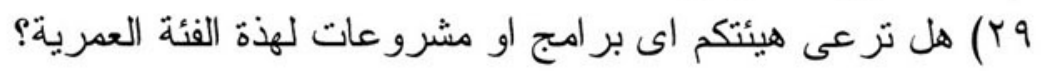

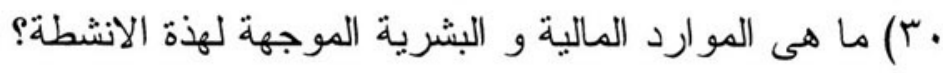

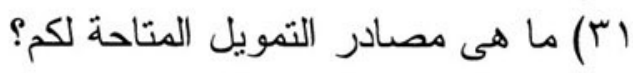

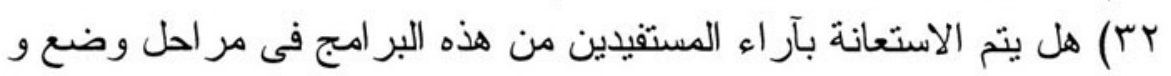

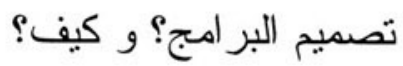


rr) كيف تقوم هيئتكم بمتابعة و تقييم هذة المشروعات و البر امج؟ ع

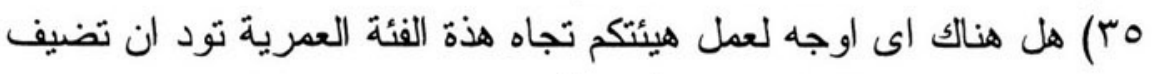

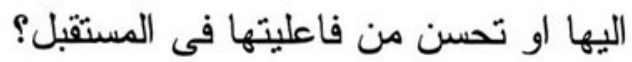

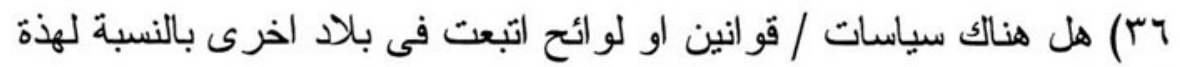

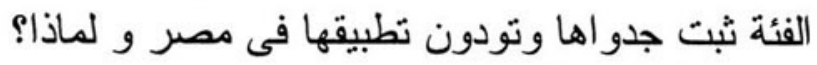

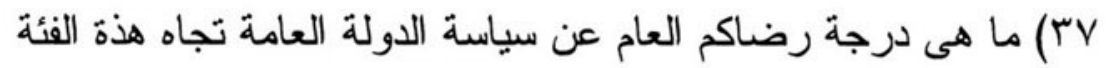
العمرية؟ ^ץr) ما هو فى رأيكم اهم قانون او قطاع يجب الاهنمام به لتحسين مستقبل هذة الفئة؟ 


\section{ملحق رقم ץ : قائمة المستشارين فى البحث}

د. جمال النحاس

مقرر مساعد للشئون الفنية المجلس القومى للسكان

السيد/ جمال عبد العزيز وزارة القوى العاملة و التذريب المهنى

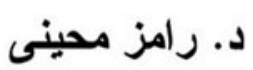

المستشار الإقليمى للصحة الإنجابية و الأسرة و المجتمع منظمة الصحة العالمية

د. سعيد النجار رئيس جمعية النداء الجديد

\author{
د. إبراهيم محرم \\ رئيس منظمة إعادة بناء وتطوير \\ القرية المصرية \\ وزارة التتمية الريفية
}

د. أمينة الجندى أمين عام المجلس القومى للطفولة و الأمومة السبد/ إسماعيل إسماعيل أمين الشباب بالحزب الوطنى إلى إسباعل الديموقر اطىى محافظة الإسماعيلية

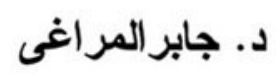
إدارة التشريع وزارة العدل 


\section{د. عايدة سيف الدولة}

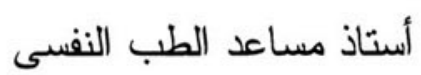

جامعة عين شمس

د. عبد السلام البنا

مستشار وزارة الشئون الاجتماعية

$$
\text { د. عبد الفتاح جلال }
$$

عميد معهد البحوث التعليمية سابقا

جامعة القاهرة

السيدة. عثمان محمدعثمان

رئيس وحدة التخطيط الكلى

معهد التخطيط القومى

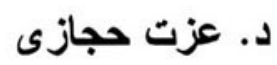

مستشار المركز القومى للبحوث

الاجتماعية و الجنائية

د - م.عزة عقيل

وكيل وزارة القوى العاملة و التدريب

المهنى
السيد/ سعيد عبد الوهاب وكيل وزارة الشئون الاجتماعية

د. سلوى جمعة

أستاذ العلوم السياسية

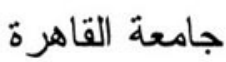

اللواء/ سمير فرج مدير إدارة الشئون المعنوية وزارة الدفاع

السيدة/ سناء البيسى رئيس تحرير مجلة نصف الدنيا

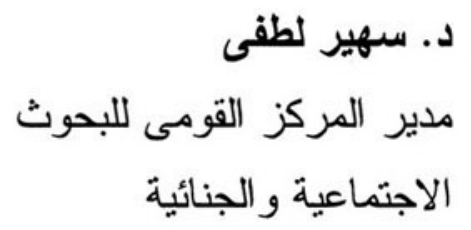

السيدة/ عايدة الاسكندرانى مدير قسم الطلائع المجلس الأعلى للشباب و الرياضة 
د. محمد برعى

رئيس قسم التشريع الاجتماعى

كلية الحقوق

جامعة القاهرة

السبد/محمد عسكر

مدير المنظمة المصرية لمنع الممارسات رئيس قسم البحث و التخطيط وزارة التعليم

السيد/محمود جمال الدين كبير مسئولى البرنامج بعثة البنك الدولى، القاهرة

السيدة. مديحة احمد نصر

ضابط انصال الجهات المانحة بالمنظمات غير الحكومية وحدة تخطيط ومتابعة البر امج
د. عزيزة جعفر

قسم الصحة و الطب الوقائى محافظة الاسكندرية
السيدة/ عزيزة كامل التقليدية الضارة بالنساء و الاطفال

السبدة/ مارى اسعد

منسق قوة عمل الشتوية الجنسى للإناث، اللجنة القومية للمنظمات غير الحكومية للسكان و التتمية

السيد/محمد الغمرى نائب مدير إدارة المسابقات المجلس الأعلى للشباب و الرياضة 


$$
\begin{aligned}
& \text { صور فوتوغر افية إهداء من : } \\
& \text { • صندوق الأمم المتحدة للأنشطة السكانية } \\
& \text { • الجامعة الأمريكية بالقاهرة ( مكتب العلاقات العامة ) }
\end{aligned}
$$

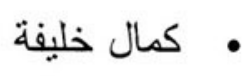

$$
\begin{aligned}
& \text { • مشيرة الجزيرى }
\end{aligned}
$$

$$
\text { تصميم وإخر اج طباعى صديق الجلاس }
$$

